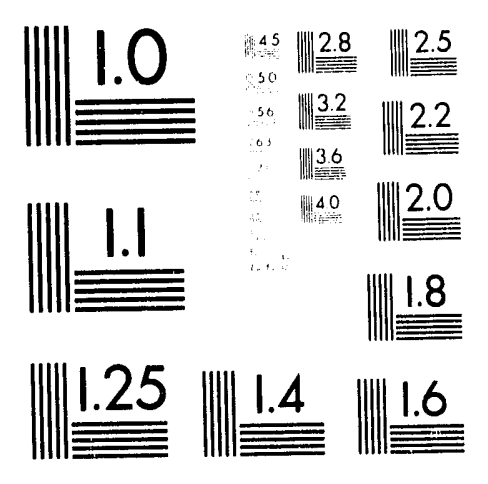




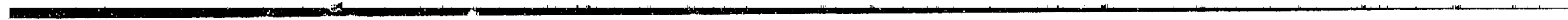


NIPER-560

Distribution Category UC-122

\title{
FEASIBILITY STUDY OF HEAVY OIL RECOVERY IN THE MIDCONTINENT REGION (KANSAS MISSOURI, OKLAHOMA)
}

Topical Report

By

D.K. Olsen

W.I. Johnson

August 1993

Work Performed Under Cooperative Agreement No. DE-FC22-83FE60149

Prepared for

U. S. Department of Energy

Assistant Secretary for Fossil Energy

\author{
Thomas Reid, Project Manager \\ Bartlesville Project Office \\ P.O. Box 1598 \\ Bartlesville, OK 74005
}

Prepared by

IIT Research Institute

National Institute for Petroleum and Energy Research

P.O. Box 2128

Bartlesville, OK 74005

\section{MASTER}




\section{TABLE OF CONTENTS}

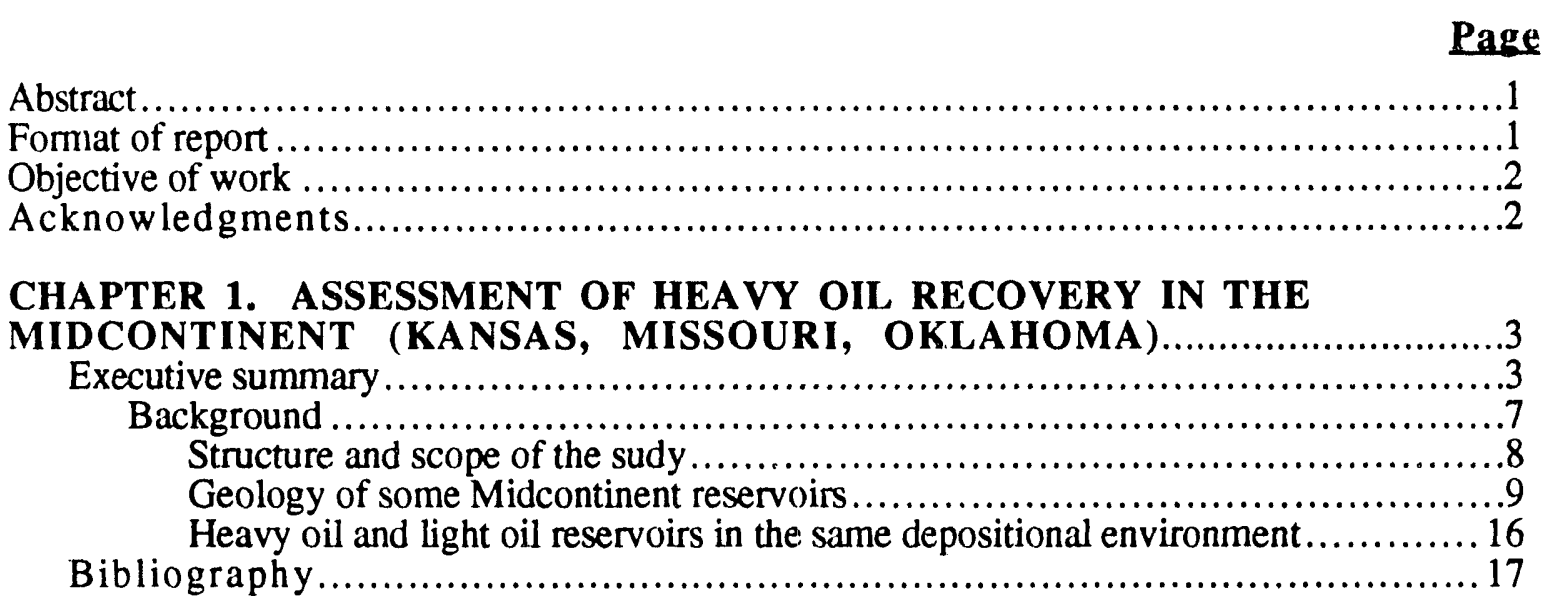

\section{TABLE}

1.1 Oil production from thermal heavy oil projects in the Midcontinent

\section{ILLUSTRATIONS}

1.1 Fluvial deltaic depositional environment showing meandering stream channels........ 10

1.2 Small scale permeability barriers found in pointbars ...................................

1.3 Pointbar deposit-common depositional environment for Pennsylvanian age petroleum reservoirs of the Midcontinent................................................ 12

1.4 Conceptual model of progressive development of a channel-fill depositional complex....

1.5 Schematic cross section of a pointbar with steam injection into center well and path of steam sweeping those continuous sands but much of the reservoir has compartments uncontacted

CHAPTER 2. HEAVY OIL OCCURRENCE AND INTEGRATED ANALYSES OF GEOLOGY AND ENHANCED OIL RECOVERY PROCESS APPLICATIONS IN KANSAS.

Summary....

Background....

20

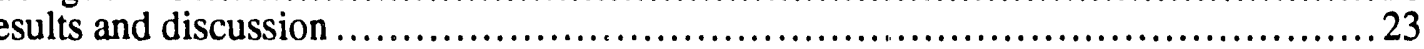

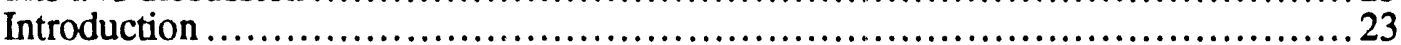

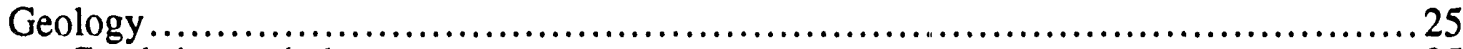

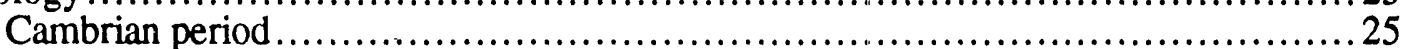

Reagan formation ............................................................. 25

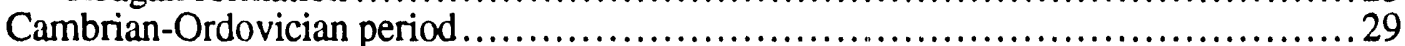

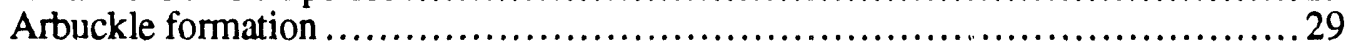

Middle Ordovician period .............................................................. 31

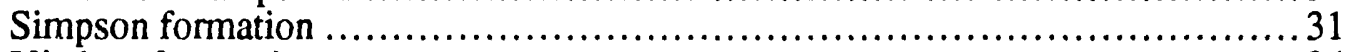

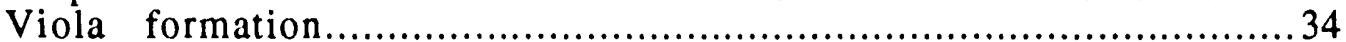

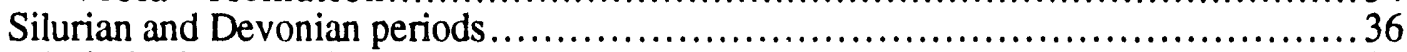

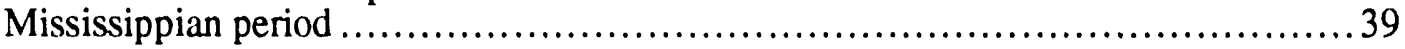




\section{TABLE OF CONTENTS-Continued}

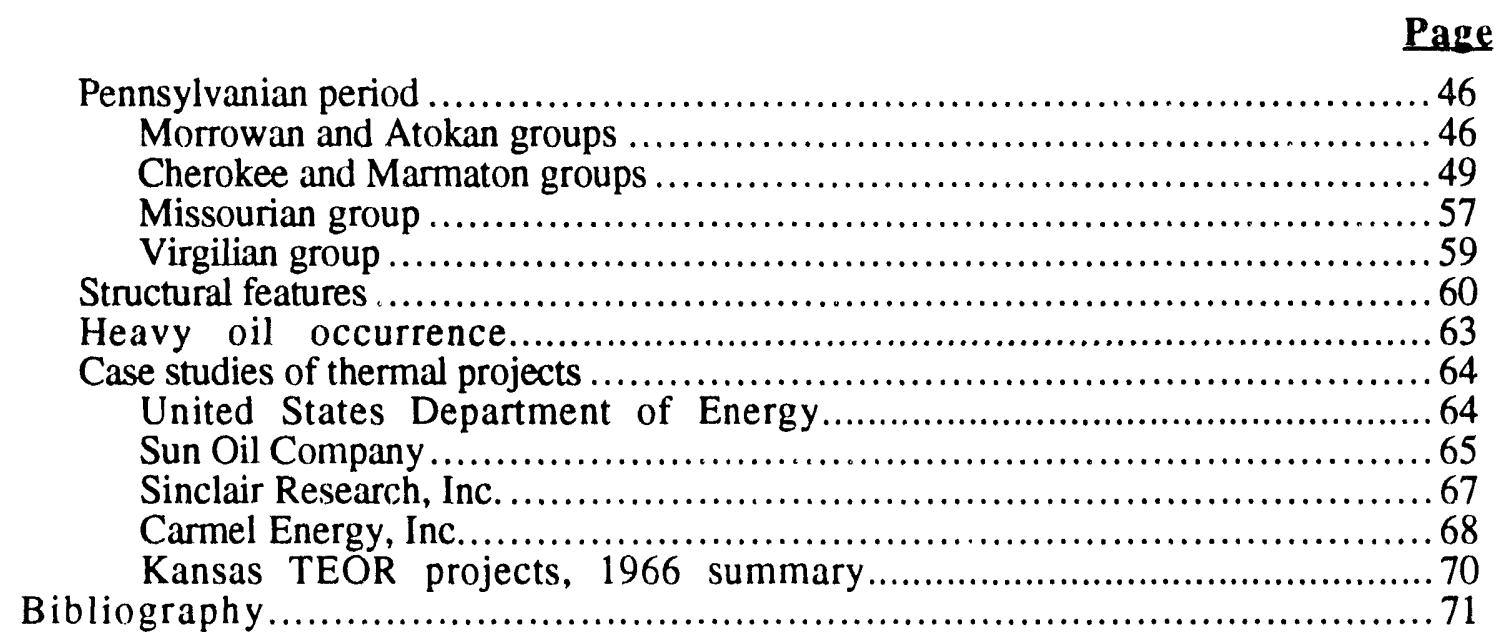

TABLES

2.1 Heavy oil reserve estimates, Eastern Kansas .......................................64 64

2.2 Average reservoir characteristics, United States Department of Energy Link Lease In Situ combustion project, Labette County, Kansas ...................................6 65

2.3 Average reservoir characteristics, Sun Oil Company Iola Fireflood Project, Moran Field, Allen County, Kansas.................................................................66

2.4 In Situ combustion process variables, Sun Oil Company Iola Fireflood Project, Moran Field, Allen County, Kansas ...................................................... 67

2.5 Sinclair Research, Inc. (1956-1960) reservoir characteristics, Humboldt-Chanute Field Fireflood Project, Allen County, Kansas...........................................6 68

2.6 Carmel Energy, Inc. (1976-1978) Carlyle Pool, Vapor Therm cyclic steam project,

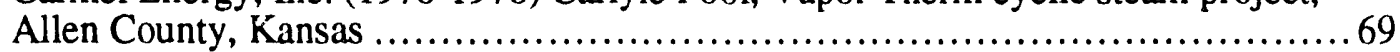

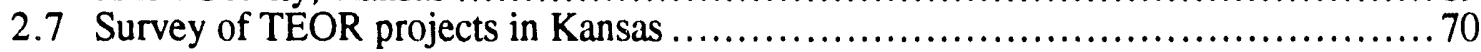

\section{ILLUSTRATIONS}

2.1 Midcontinent Basins ............................................................ 20

2.2 Formal stratigraphic classification of the Cherokee Group............................21

2.3 Geologic timetable and Kansas rock chart showing the various producing zones considered in this report.

2.4 East Kansas asphaltic sandstone outcrops and quarries ..................................22

2.5 East Kansas asphaltic limestone outcrop and quarries ............................ 24

2.6 Time stratigraphic units-Cambrian and Ordovician systems .............................2 25

2.7 Map showing general thickness of the Reagan Sandstone in Kansas. Map base shows generalized distribution of rocks which rest on the Precambrian............ 26

2.8 Diagram showing proposed lithologic and overlap relationships between the Reagan Sandstone and the Arbuckle Group over Precambrian "highs" in Central and Northwest Kansas

2.9 West-east cross section, based on logs of Kansas Sample Log Service, across Cambridge Arch showing relation of lower Pennsylvanian rocks to older beds on crest of arch. 


\section{ILLUSTRATIONS-Continued}

2.10 Preliminary regional configuration map on top of Precambrian basement complex in Kansas. This map shows present day depth in Kansas ................. 27

2.11 Map of Kansas showing generalized Precambrian basement rock-type distribution based on about 2,200 wells ...................................... 28

2.12 Stratigraphic diagram showing relationships between Paleozoic rocks and Precambrian rocks in Northwestern Kansas ..................................... 28

2.13 Map of Kansas showing subsurface distribution of Arbuckle Group

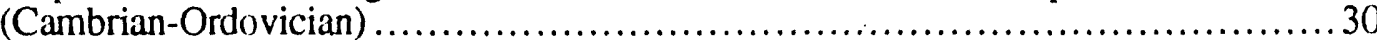

2.14 Preliminary regional structural map contoured on top of Arbuckle rocks

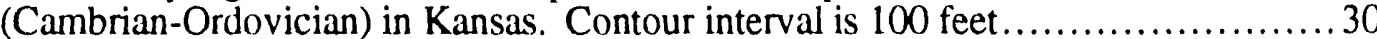

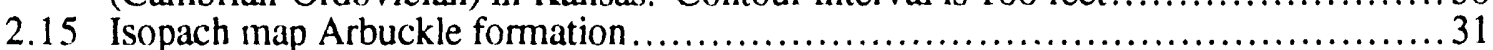

2.16 Pre-Mississippian-post-Devonian structural features in Kansas.......................32

2.17 Map of Kansas showing subsurface distribution of Simpson Group (Middle

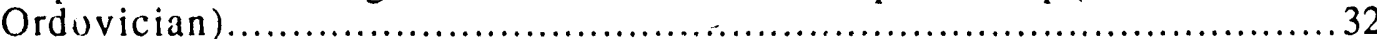

2.18 Pre-Mississippian-post-Ordovician structural features of Kansas. Subcrop pattern of Simpşon below the Chattanooga ......................................... 33

2.19 Pre-Pennsylvanian sediments in contact with Pennsylvanian in an Eastern

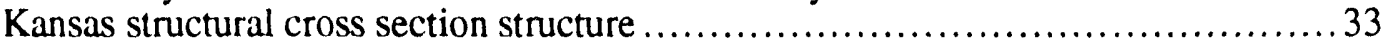

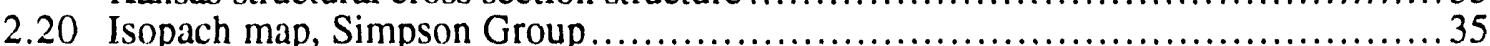

2.21 Generalized stratigraphic section of the Viola limestone in South-Central Kansas ...................................................................... 35

2.22 Map of Kansas showing subsurface distribution of Viola limestone

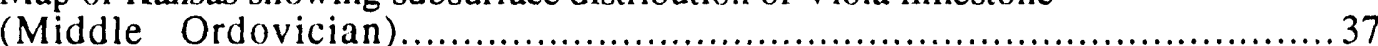

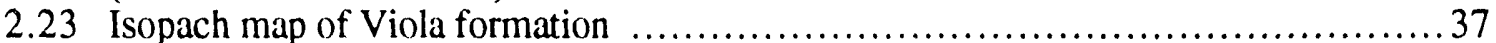

2.24 Stratigraphic column of the Ordovician, Silurian, and Devonian systems in Kansas................................................................... 38

2.25 Map of Kansas showing subsurface distribution of "Hunton" rocks ................... 40

2.26 Preliminary regional structural map contoured on top of "Hunton" rocks (Silurian-Devonian) in Kansas. Contour intervals are $100 \mathrm{ft} \ldots \ldots \ldots \ldots \ldots \ldots \ldots \ldots \ldots . . . . . . . . .40$

2.27 Preliminary regional structural map contoured on top of Mississippian

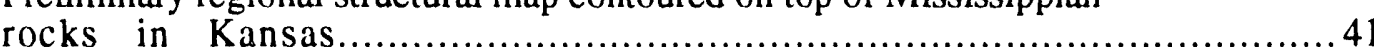

2.28 Isopachous map of "Mississippi Lime" in Southeastern Kansas .................... 41

2.29 Sketch map showing main structural elements in Kansas during Mississippian time........................................................................ 42

2.30 Sketch map of Kansas showing inferred post-Devonian pre-Mississippian

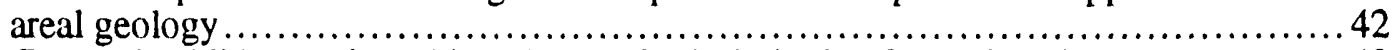

2.31 Generalized lithostratigraphic column of Mississippian formations in Kansas ......... 43

2.32 Composite stratigraphic section of the Osagean series. Lithology versus geophysical $\log$ response.

2.33 Structural cross sections in Eastern Kansas showing relation of Mississippian deposits to younger and older units

2.34 Map of Kansas showing generalized distribution of Mississippian units below Pennsylvanian deposits. Area of controversial Cowley formation is shown in South-Central Kansas.

2.35 Map of Kansas showing rocks underlying Pennsylvanian beds. Mississippian rocks are present except on Nemaha Anticline, Central Kansas Uplift, Cambridge Arch, and Pratt Anticline, where rocks as old as Precambrian underlie Pennsylvanian. 


\section{ILLUSTRATIONS-Continued}

Page

2.36 Subsurface distribution of lower Pennsylvanian rocks in Kansas.

A. Morrowan and B. Desmoinesian and Atokan.....................................47

2.37 Map of Kansas showing surface and subsurface distribution of

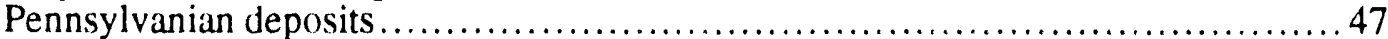

2.38 Sketch map showing early Pennsylvanian structural provinces in Kansas ............ 48

2.39 Pennsylvanian tectonic settings in Kansas and Oklahoma.............................4.48

2.40 Stratigraphic classifications of the Cherokee group in Southeastern Kansas.............. 50

2.41 Major post-Mississippian, pre-Desmoinesian structural elements of Kansas ...........50)

2.42 Basic vertical sequence of an individual Kansas Pennsylvanian cyclotherm, which is generally characteristic of Marmaton, Kansas City, Lansing, and Shawnee groups, showing lithology and interpreted environments and phases of deposition

2.43 Basic pattern of lateral facies relations in generalized Kansas cyclotherm across facies belts exposed along Midcontinent outcrop. Datum is interpreted approximate sea level at time that increased detriatal influx terminated deposition of regressive limestone member

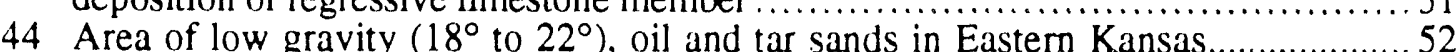

2.45 Vertical succession of facies in Cherokee fluvial shoestring sandstones .............. 53

2.46 Cross section of fluvial-dominated deltaic channel sand showing upper facies (continuous and discontinuous between wells) compartment and lower facies (more continuous sand)

2.47 Correlation of a composite log of well KE-92 (GR-N log-lithology log-core analysis) with well log of WH-69, Eastburn Sandstone, Eastburn Field, Vernon County, Missouri ................................................. 54

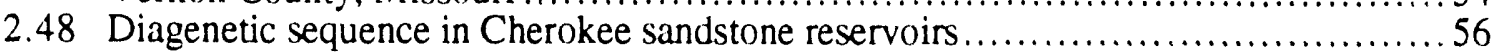

2.49 Stratigraphic column Missourian and Virgilian series, Pennsylvanian

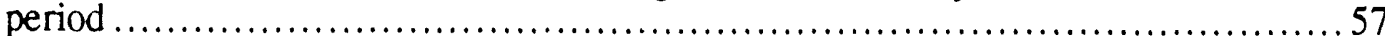

2.50 Thickness and principal lithologies of lower desmoinesian (Cherokee group equivalent) strata in the Midcontinent ......................................... 58

2.51 Preliminary regional structural map contoured on top of Lansing group (Missourian, Pennsylvanian) in Kansas.

2.52 Map of Eastern Kansas showing the approximate configuration of the upper surface of Pre-Cambrian rocks and Nemaha Uplift. Contour intervals are drawn

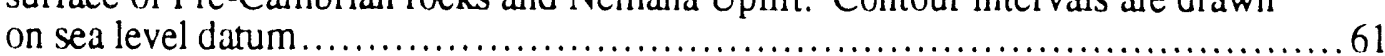

2.53 Map of Landsat photolineaments in the southwestem corner of the study area....... 62

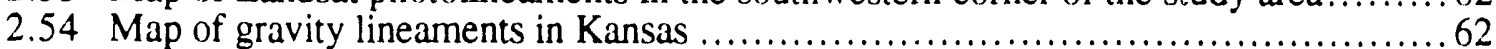

2.55 Map of aeromagnetic lineaments in Kansas .....................................6 63

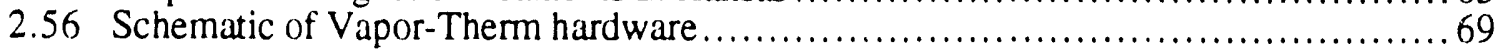

CHAPTER 3. HEAVY OIL OCCURRENCE AND INTEGRATED ANAI.YSES OF GEOLOGY AND ENHANCED OIL RECOVERY PROCESS APPLICATIONS

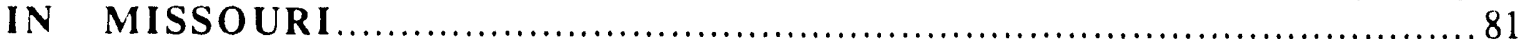

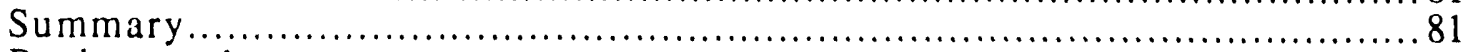

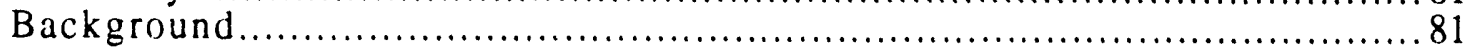

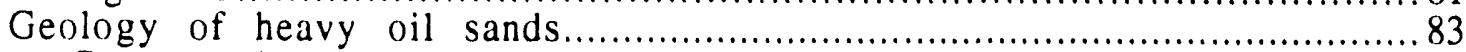

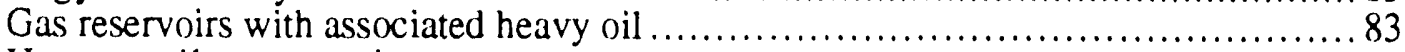

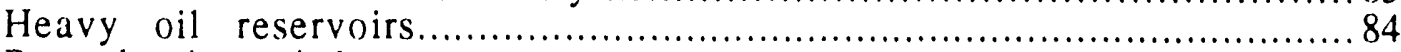

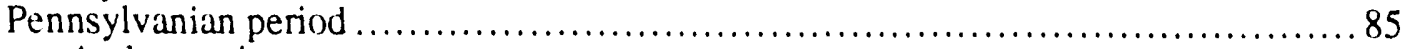

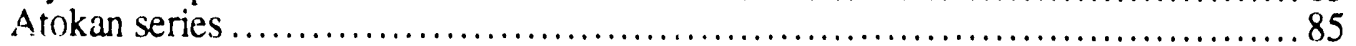




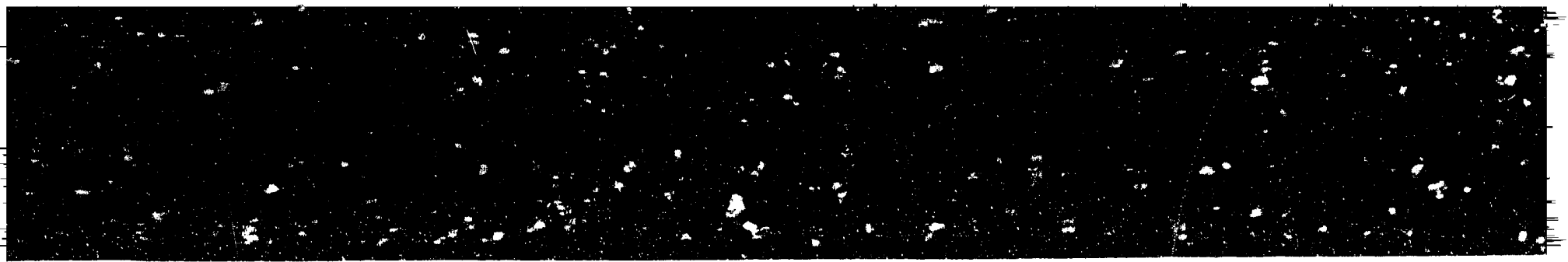

TABLE OF CONTENTS-Continued

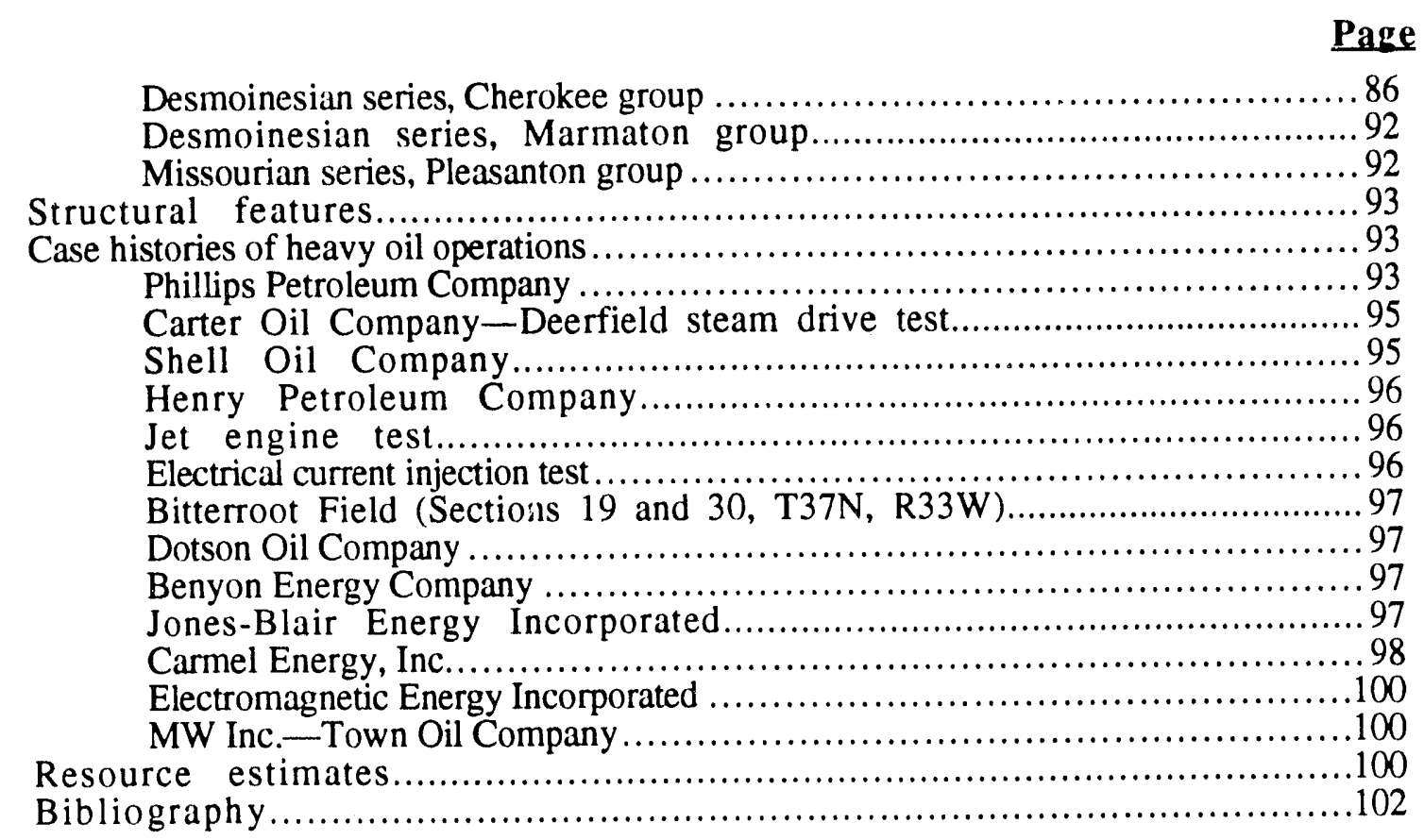

TABLES

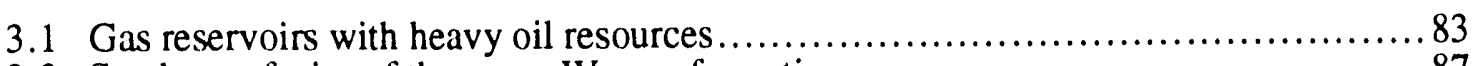

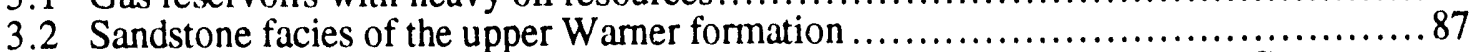

3.3 Inferred paragenetic sequence of the "Upper Warner" sandstone, Vernon County,

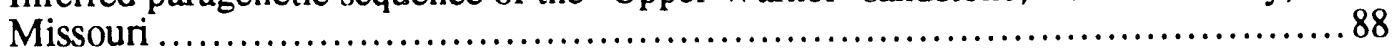

3.4 Stratigraphic sequence of the Eastburn sandstone, Eastburn field, Vernon County

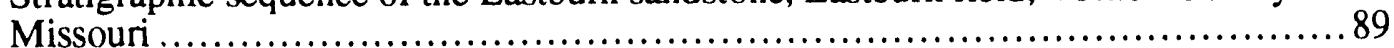

3.5 Phillips Petroleum Company (1955-1958) counterflow In Situ combustion process, Bellamy, Missouri........................................................... 94

3.6 Carter Oil Company (1955-1959) steam drive test, Deerfield, Missouri ............... 96

3.7 Shell Oil Company (1963-1966) thermal oil recovery (fireflood and steam) test,

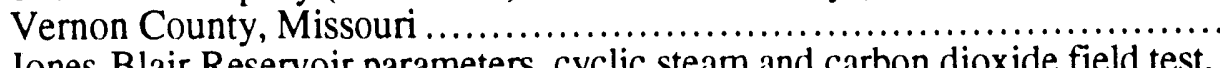

3.8 Jones-Blair Reservoir parameters, cyclic steam and carbon dioxide field test, Stotesbury field, Vernon County, Missouri (1982-1987) ........................... 99

3.9 Reservoir Parameters, Vapor Therm TEOR process, Carmel Energy, Inc. Eastburn field, Vernon County, Missouri

\section{ILLUSTRATIONS}

3.1 Generalized columnar section of Pennsylvanian strata for Western and Northwestern Missouri......................................................... 82

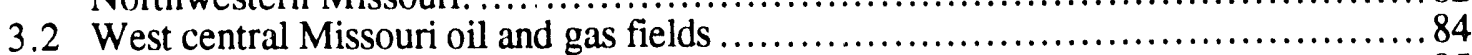

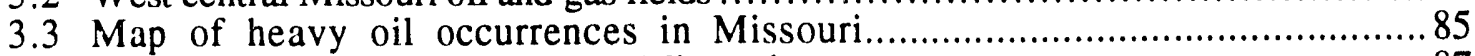

3.4 Oil bearing sandstones in Western Missouri ....................................... 87

3.5 Isopachous map of Eastburn sandstone, Eastburn Field, Vernon Co. Missouri .......90

3.6 Stratigraphic cross section of Eastburn sandstone......................................... 91

3.7 Annual heavy oil production in Missouri, total and principal reservoirs.................102 


\section{TABLE OF CONTENTS-Continued}

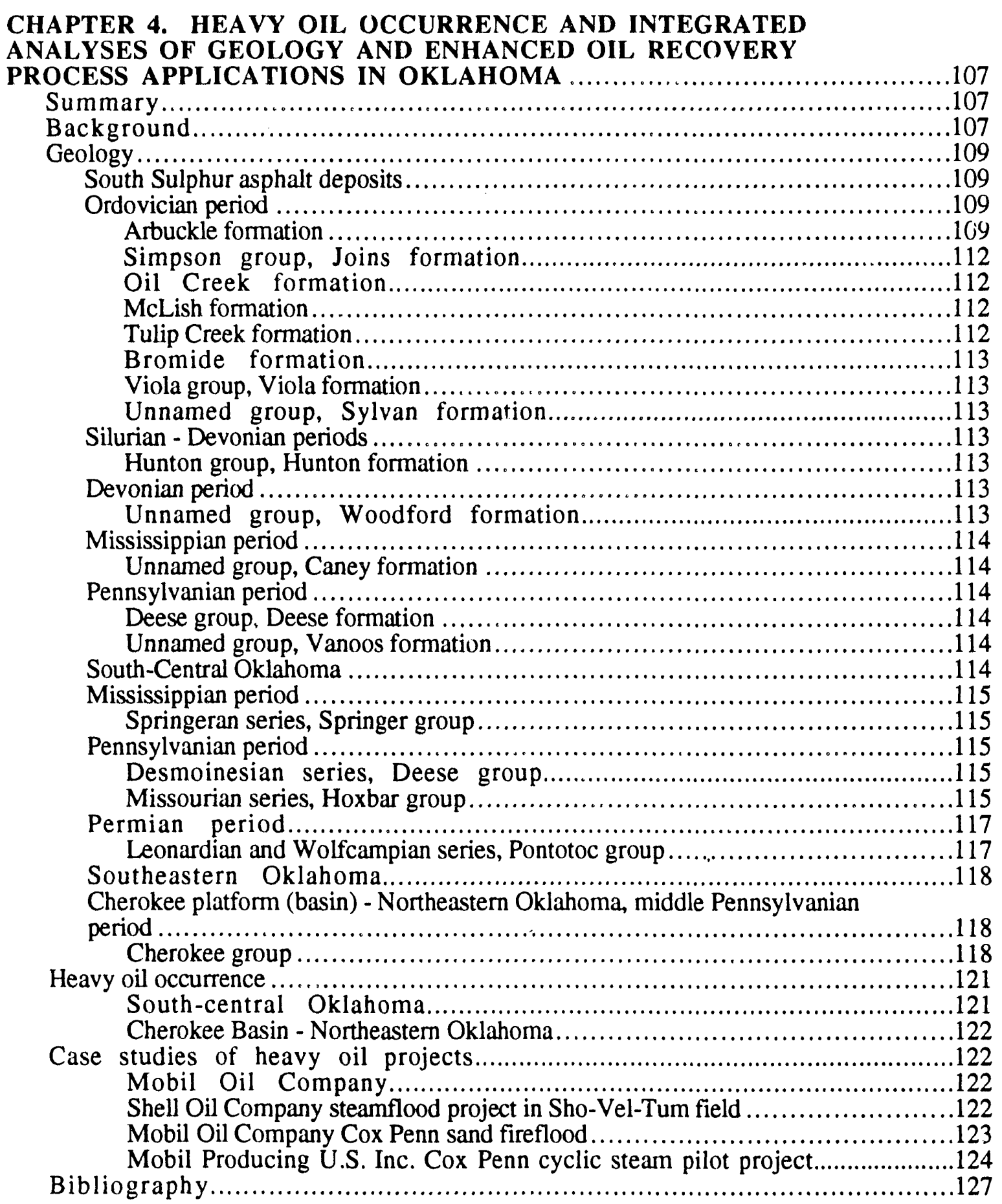




\section{TABLES}

4.1 Shell Oil Company, steamflood project, Sho-Vel-Tum field, Carter County, Oklahoma (1964-1966)

4.2 Mobil Oil Company, Cox Penn sand fireflood, Sho-Vel-Tum field, Carter County,

Oklahoma (1962-1968) .................................................... 124

4.3 Mobil Producing U.S. Inc., Cox Penn cyclic steam, Sho-Vel-Tum field, Carter County, Oklahoma (1986-present)

\section{ILLUSTRATIONS}

4.1 Map showing area in Craig and Ottawa counties which was investigated for heavy oil

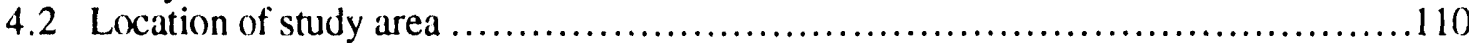

4.3 Southern Oklahoma Fold Belt showing structural provinces .......................110

4.4 Stratigraphic section, South Sulphur area, Murray County, Oklahoma ................111

4.5 Columnar section of outcropping Pennsylvanian strata in the Ardmore basin .........116

4.6 Stratigraphic column of Pennsylvanian and Permian strata in the Anadarko basin and the Hugoton Embayment ...............117

4.7 Index map of Oklahoma showing location of McCurtain County and of the area covered by this report. Inset map shows principal features in this county..............119

4.8 Generalized section of Cretaceous and younger rocks in McCurtain County, Oklahoma....

4.9 Structural Detail at inlier of Washita group along Bokchito Creek. Kwt, Woodbine Formation; Kw, Washita group ..........................................120

4.10 Geologic map of a portion of McCurtain County, Oklahoma..............................120

4.11 Nomenclature of middle Pennsylvanian rocks in the Tri-State area .................121

4.12 Depositional environment of the Cox Penn reservoir ...................................125

4.13 Schematic cross section of the Cox Penn reservoir ..............................125

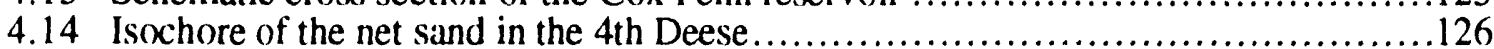

4.15 Schematic cross section of the Cox Penn reservoir .............................

\section{CHAPTER 5. ECONOMICS OF THERMAL HEAVY OIL PRODUCTION-}

OKLAHOMA， KANSAS， MISSOURI..........................................133

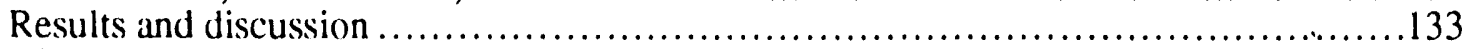

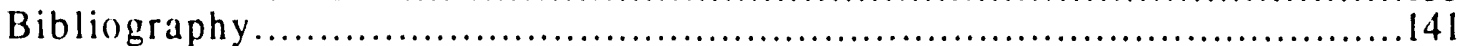

\section{TABLES}

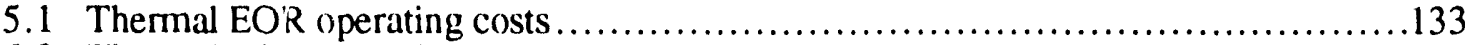

5.2 Thermal EOR operating costs-suggested yearly thermal steam operating cost

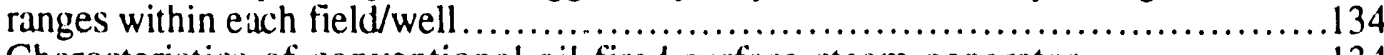

5.3 Characteristics of conventional oil-fired surface steam generator........................134

5.4 Conventionad oil-fired surface steam generator costs .............................135

5.5 Cost to dril! and equip a $1,000 \mathrm{ft}$ steam injection well ............................137

5.6 Cost to drill and equip a 1,000 ft steam production well....................................137

5.7 Oil production in thermal heavy oil projects in the Midcontinent ........................138

5.8 Comparison of economic factors affecting oil production from Midcontinent

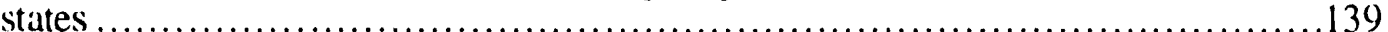

5.9 Crude oil prices of the last decade ............................................................. 140 


\section{ILLUSTRATIONS-Continued}

Page

5.1 Comparison of average yearly oil price of benchmark crude oils with

Kern River $13^{\circ}$ API gravity oil.

CHAPTER 6. APPLICATION FOR HORIZONTAL WELLS AND

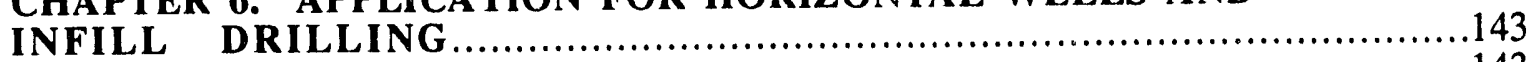

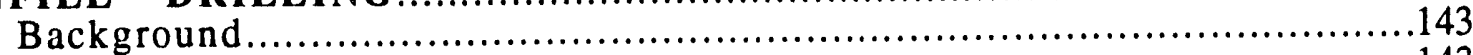

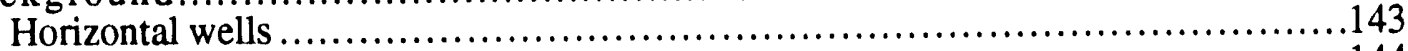

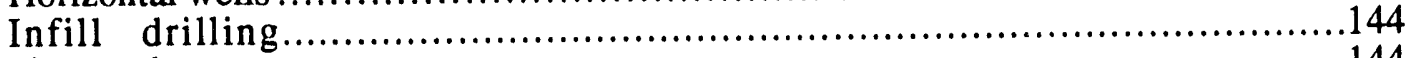

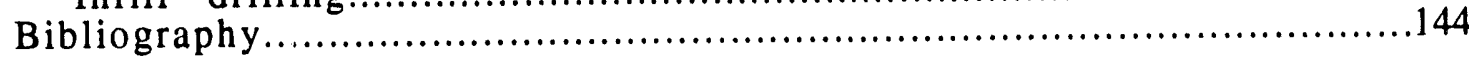

CHAPTER 7. ENVIRONMENTAL FACTORS AFFECTING HEAVY

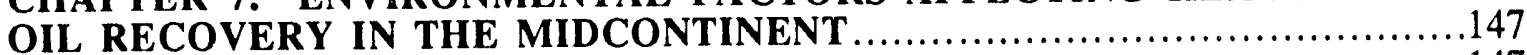

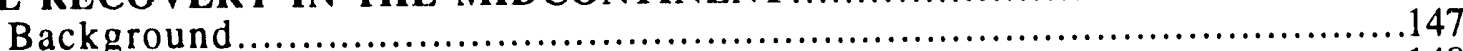

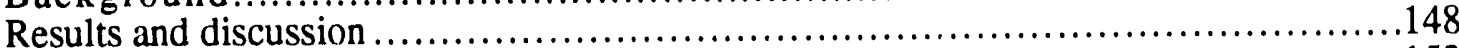

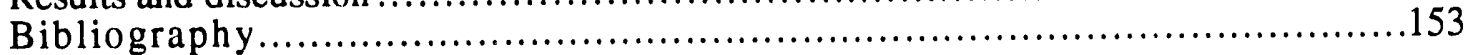

TABLE

7.1 Typical emissions from an oil-fired steam generator.

CHAPTER 8. HEAVY OIL TRANSPORT AND REFINING

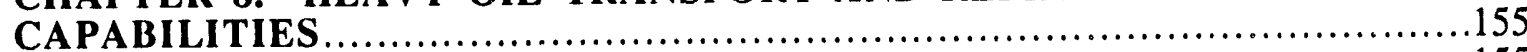

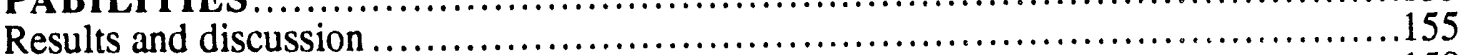

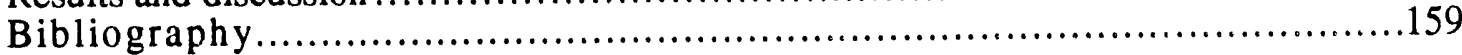

\section{TABLES}

8.1 Refinery capabilities of Kansas and Oklahoma .................................. 156

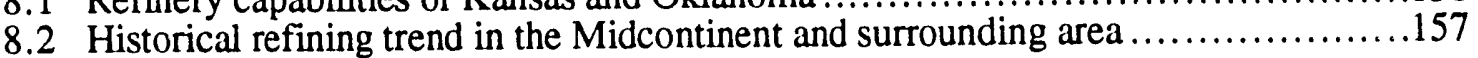

\section{ILLUSTRATIONS}

8.1 Total number of U.S. refineries

CHAPTER 9. CONCLUSIONS AND RECOMMENDATIONS .................161

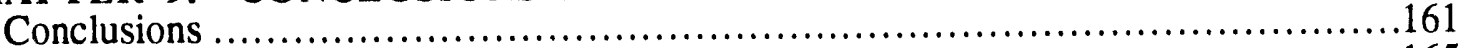

Recommendations

CHAPTER 10. TABULAR LISTING OF HEAVY OIL RESERVOIR

PROPERT I E S

\section{TABLE}

10.1 Midcontinent heavy oil reservoir ciata (major reservoirs) 


\title{
FEASIBILITY STUDY OF HEAVY OIL RECOVERY IN THE MIDCONTINENT REGION (KANSAS, MISSOURI, OKLAHOMA)
}

\author{
By D. K. Olsen and W. I. Johnson
}

\begin{abstract}
This report is one of a series of publications assessing the feasibility/constraints of increasing domestic heavy oil production. Each report covers a select area of the United States. The Midcontinent (Kansas, Missouri, Oklahoma) has produced significant oil, but contrary to early reports, the area does not contain the huge volumes of heavy oil that, along with the development of steam and in situ combustion as oil production technologies, sparked the area's oil boom of the 1960s. Recovery of this heavy oil has proven economically unfeasible for most operators due to the geology of the formations rather than the technology applied to recover the oil.

The geology of the southern Midcontinent, as well as results of field projects using thermal enhanced oil recovery (TEOR) methods (cyclic steam, steamflooding, steam and combustion gas, and in situ combustion) to produce the heavy oil, was examined based on analysis of data from secondary sources. Analysis of the performance of these projects showed that the technology recovered additional heavy oil above what was produced from primary production (often as small as $0.3 \mathrm{BOPD} /$ well) from the consolidated, compartmentalized, fluvial dominated deltaic sandstone formations in the Cherokee and Forest City basins. The only projects producing significant economic and environmentally acceptable heavy oil in the Midcontinent are in higher permeability ( $>500 \mathrm{mD}$ ), unconsolidated or friable, thick sands such as those found in south-central Oklahoma. There are domestic heavy oil reservoirs in other sedimentary basins that are in younger formations, are less consolidated, have higher permeability and can be economically produced with current TEOR technology. Heavy oil production from the carbonates of central and western Kansas has not been adequately tested, but oil production is anticipated to remain low.

The Midcontinent has an extensive, aging, light crude oil collection and transportation pipeline network. Refineries are small, sweet, light oil refineries with little capacity to process heavy oil. Significant expansion of Midcontinent heavy oil production is not anticipated because the economics of oil production and processing are not favorable.
\end{abstract}

\section{FORMAT OF REPORT}

This report is divided into four sections. The first part, chapter 1, provides a summary of the findings of the study, an explanation of the reasons why the authors believe the oil resource will remain undeveloped, and some background of previous studies. The second part, chapters 2 through 4 , provides the geologic background for the heavy oil analysis that was undertaken. This 


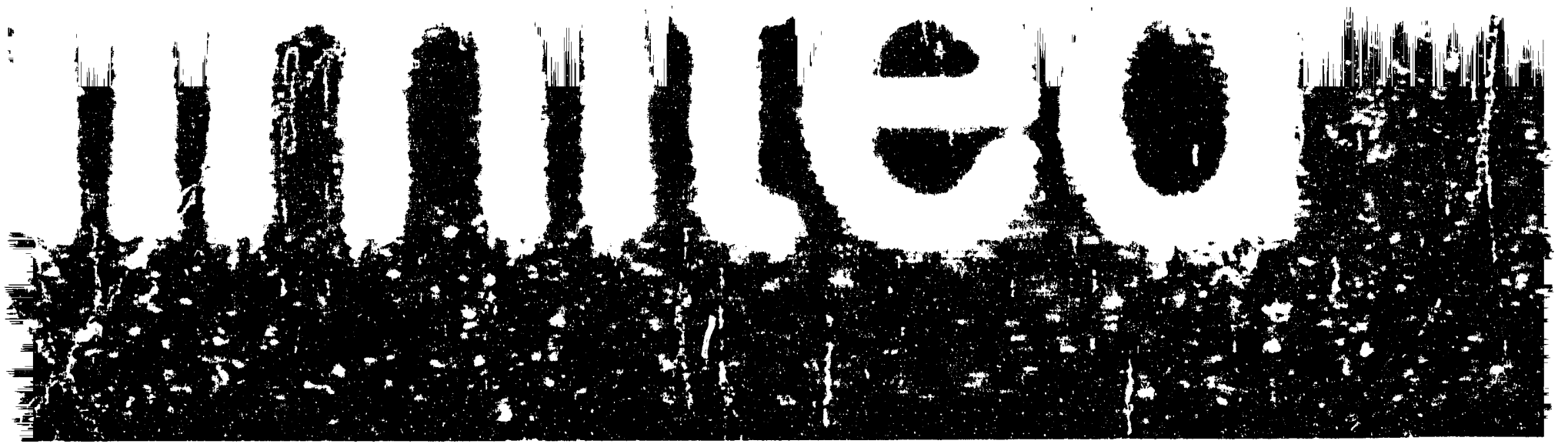

search was undertaken because numerous previous references reported large heavy oil resources but their definition of "heavy oil" was broad and the geology of many of the oil bearing formations was not as well defined as currently known. These chapters contain extensive bibliographies that provide a listing where more detailed information can be obtained on a given geologic formation or area. The third part, chapters 5 through 8 , covers the economics of production, potential of horizontal drilling, environmental factors influencing oil development, and oil transport and refining limitations. The fourth part, chapters 9 and 10, contains the conclusions and recommendations and a tabular listing of average reservoir data for heavy oil reservoirs in Kansas, Missouri, and Oklahoma. Emphasis of the report is not the reservoir database, since this is secondary to defining the problems that limit development of the heavy oil resource.

\section{OBJECTIVES OF RESEARCH}

The objectives of this feasibility study were (1) to identify and investigate the known heavy oil resources in the Midcontinent based upon publicly available information, (2) to screen this resource for potential thermal or other EOR application to produce this oil, and (3) to evaluate various economic factors/constraints that may impact the development of this resource. If the study had determined that expansion of production of heavy oil in this area were economically possible, recommendations would have been made to facilitate the production of this resource.

\section{ACKNOWLEDGMENTS}

This work was sponsored by the U.S. Department of Energy under cooperative agreement DE-FC22-83FE60149 as part of project SGP37. The authors thank E. B. Ramzel of NIPER for the database development and economic analysis; DOE/NIPER Student Interns, Everett Taylor, Robert Pendergrass, Jonathan Grigsby and Heather Horstman for preparation of the figures; R. Schatzinger, M. K. Tham and A. Strycker of NIPER, and T. B. Reid of the DOE Bartlesville Project Office for their critical reviews. The authors wish to thank the staff of the geologic surveys of Kansas, Oklahoma, and Missouri and the regulatory agencies of these states for their cooperation in defining the potential of heavy oil recovery in these states. 


\section{CHAPTER 1}

\section{ASSESSMENT OF HEAVY OIL RECOVERY IN THE MIDCONTINENT (KANSAS, MISSOURI, OKLAHOMA)}

\section{EXECUTIVE SUMMARY}

The Midcontinent region (Kansas, Missouri, Oklahoma) has developed a reputation for containing significant heavy oil. Major oil companies had millions of acres under lease during the 1960s and 1970s. The question continues to be asked "Why hasn't this heavy oil been developed like the heavy oil reserves of California, where more than $70 \%$ of California's oil production is heavy oil?" The answer to this question lies in the geology of the Midcontinent heavy oil reservoirs. Previous reports that incicated billions of barrels of heavy oil in Pennsylvanian age formations in the Cherokee Basin were speculative and based upon considering the formations as widespread blanket sands where heavy oil appeared in numerous wells. More recent U.S. DOE supported studies indicate that these heavy oil resources are of the magnitude of hundreds of millions of barrels. NIPER's analysis of the geology shows many of the fluvial dominated deltaic reservoirs are highly compartmentalized, have complex internal architecture, and are fractured. Aerial photos show surface fractures, which are an indication that shallow reservoir rock and confining beds may also be fractured. Many previous TEOR operations (cyclic steam, steamflooding, steam and combustion gas, and in situ combustion) provided only nominal oil production above primary production (often $<0.3 \mathrm{bbl} /$ well/day). Some oil recovery operations repressurized the reservoir, and, in some instances, oil and produced water leaked to the surface. In today's safety and environmentally conscious petroleum industry, the environmental problems associated with shallow aquifer contamination or leakage to the surface are unacceptable/uneconomic risks.

Thermal recovery of heavy oil has been tested since the early 1960 s in the Cherokee and Forest City basins as well as other parts of thc Midcontinent. This area was one of the original areas where numerous petroleum companies tested heavy oil recovery technologies. Major TEOR technologies have not changed since the early 1960s although efficiency in steam generation, delivery of steam to the formation (insulated tubulars), heat management, emission control using gas-fired rather than oil-fired steam generators, and treatment of emulsions in produced fluids has significantly improved. The technology used in the field tests in the Midcontinent by many of these early operators was basically the same as current technology. In the early years of TEOR, results from operations were company secrets. In the last 15 years, thermal recovery with steam has been commercialized and well documented. Many of the world's TEOR operators learned from their TEOR pilots that they conducted in the Midcontinent and elsewhere and moved their operations to fields with younger formations that are thicker, are unconsolidated or friable, have 
more oil per acre, have more oil per acre foot, and thus are more amenable to economic thermal heavy oil production.

Some of the results (lessons learned) from the early pilots are highlighted in this report. During the course of this study, NIPER contacted operators and former operators of heavy oil producing operations in the Midcontinent. The discussions indicated that major oil companies and some independents learned from their pilot tests in the Midcontinent and other TEOR pilots conducted throughout the world during the 1960s and 1970s. Some operators may not have had access to or time to analyze all the literature which was available to the public or perhaps read only the early speculative literature which did not specifically spell out the limitations of oil recovery from tight, consolidated, fractured, compartmentalized formations typical of the Cherokee Basin and much of the Pennsylvanian Age Midcontinent reservoirs. A number of smaller operators that were contacted continue to cite early trade journal and government reports that expound on the availability of the billions of barrels of heavy oil in the region. These reports were based on these reservoirs being continuous formations rather then reflecting the actual geology and the results of more recent U.S. DOE and state funded studies.

The best estimates of heavy oil resources in sandstone reservoirs are those of Missouri, and the least well known are those in Oklahoma. Economically recoverable heavy oil for the Cherokee Basin is estimated at $5,000,000 \mathrm{bbl}$, whereas the estimated recoverable heavy oil from friable or unconsolidated sand formations of south-central Oklahoma is estimated to be $40,000,000 \mathrm{bbl}$. These are low recovery factors for consolidated sediments and higher $(>30 \%)$ for unconsolidated sands, but this is due to the geology of the reservoirs rather than the oil recovery process. Heavy oil contributes to Midcontinent oil production, but not significantly. Although Missouri has the highest percentage of heavy oil to total oil produced for any state in the Nation, the total annual production is less than $20 \%$ of the daily heavy oil production of California.

This study has determined that heavy oil recovery from low-permeability, fluvial-dominated, consolidated sandstone reservoirs such as those of the Cherokee Basin, with current technology including that of horizontal wells, would be marginal or uneconomic (only a small fraction of the resource is amenable to economic recovery). The steeply dipping, high-permeability ( $>500 \mathrm{mD})$, unconsolidated sands that are on the north side of the Arbuckle mountains in south-central Oklahoma produce heavy oil by primary as well as by thermal methods. It is from these more massive unconsolidated or friable sandstone formations that heavy oil has the best potential for being economically produced. In these unconsolidated sands, TEOR on close spacing can supply heat to reduce oil viscosity and gravity drainage can assist oil recovery. Neither recovery from nor estimation of the volume of the resource of heavy oil in carbonate reservoirs of central and western Kansas has been adequately tested, but oil production is anticipated to remain low. Current tests of 
thermal heavy oil recovery from carbonate reservoirs are being conducted in Canada and Turkey and will help to define the future potential for heavy oil production from carbonates.

The refineries in the Midcontinent (Kansas, Missouri, Oklahoma) are small volume, light, sweet crude refineries constructed decades ago to process locally produced oil. They are not designed to process heavy oil and have little hydrocracking and coking capacity. If heavy oil were made available from outside the region, these refineries would quickly lose their efficiency and the ability to process light oil because processing the heavy ends of crude $\left(>1050^{\circ} \mathrm{F}\right.$ ) limits their entire operation. Many older, smaller, refineries closed during the last decade, and more refinery abandonments are anticipated within the next decade. This is due to declining supplies of local light sweet oil, economy of scale, and the fact that these plants have older, less efficient units that do not allow for an adequate economic rate of return to meet the demands imposed by higher product quality and the necessary investment in upgrades to meet environmental regulations. The pipeline network of the Midcontinent region could dilute a small volume of heavy oil with light crude but only on a limited scale because there are no heated pipelines in the network.

Although these states contain heavy oil listed as resources, only a very small fraction is amenable to economic recovery. The three states have been the site of over 30 years of field pilot tests designed to recover heavy oil. With few exceptions, each project produced heavy oil, but in only three projects was the rate of oil production high enough to continue expansion or continued operation. One of these projects would probably be suspended in today's environmentally conscious petroleum industry. Of the three projects deemed possibly economic, their geologic setting and the oil recovery process combined to make the project a success. In most pilots the oil recovery process worked but the geologic environment (internal architecture of the reservoir) limited economic success.

The conclusions of the technical, historical, and economic analyses of previous heavy oil recovery projects (1955 - 1990) conducted in shallow heavy oil Midcontinent reservoirs, include:

1. Economic thermal heavy oil production has been shown for the unconsolidated, dipping, high-permeability reservoirs of south-central Oklahoma where the oil migrated into reservoirs early, and extensive diagenesis of reservoirs has not occurred. Stripper production of heavy oil is marginally economic in most of the Midcontinent (about $0.3 \mathrm{bbl} /$ well/day).

2. Heavy oil is recoverable by thermal processes from shallow consolidated sandstone reservoirs in the Midcontinent. In situ combustion, steamflooding (drive), cyclic steam, and steam injection processes combined with injection of hot gases (Vapor Therm and others) were technically successful thermal processes conducted in Midcontinent sandstone reservoirs during the last 30 years. However, most of the technically successful projects were economically unsuccessful. 
3. Implementation of TEOR processes in thin fluvial deltaic consolidated sandstone heavy oil reservoirs may not be economic, (see Table 1.1).

4. Only a site specific economic/engineering/geologic analysis can determine if the recovery process chosen for a specific reservoir may be economic. A pilot test is required to customize the process to determine site-specific constraints and technical and economic feasibility.

5. The most favorable facies for best recovery of incremental heavy oil in consolidated sandstone deposited by a fluvial-dominated deltaic system in the Midcontinent is a trough-bedded channel-fill facies. Poor heavy oil recovery results from implementing TEOR processes in more compartmentalized, discontinuous-bedded, lenticular, upper pointbar, channel-fill sandstone facies. There are more reservoir quality damaging diagenetic changes, including bedding boundary permeability barriers, in upper facies sandstones than in trough-bedded, lower facies sandstones. Reservoir analysis can help to determine where the better geologic facies for process implementation may be located in a reservoir.

6. Fields with old stripper wells, wells with poor casing integrity, poorly plugged wells or unknown wells are liabilities with TEOR processes or recovery processes that significantly increase reservoir pressure. TEOR requires wells to be properly completed to accommodate heat and pressure. Well spacing must be less than that of compartmentalization (usually less than 1 acre). TEOR well spacing in many unconsolidated sands in California oil fields is $1-1 / 4$ or $5 / 8$ acre spacing. East Texas field of East Texas was developed on 1-3/4 acre spacing.

TABLE 1.1. - Oil production from thermal heavy oil projects in the Midcontinent

\begin{tabular}{|c|c|c|c|c|c|c|c|}
\hline Description & Location & Process & $\begin{array}{l}\text { Project } \\
\text { life, } \\
\text { yr }\end{array}$ & $\begin{array}{l}\text { Total } \\
\text { oil } \\
\text { barrels }\end{array}$ & $\begin{array}{c}\mathrm{CDOR}_{1}{ }^{1} \\
\text { barrels }\end{array}$ & Wells & $\mathrm{BOPD} / \mathrm{w}^{3}$ \\
\hline $\begin{array}{l}\text { U.S. DOE } \\
\text { Sun Oil } \\
\text { Sinclair }\end{array}$ & $\begin{array}{c}\text { Bartlett, KS } \\
\text { Iola, KS } \\
\text { Allen Co., KS }\end{array}$ & $\begin{array}{l}\text { Fireflood } \\
\text { Fireflood }\end{array}$ & 4 & $\begin{array}{c}\mathrm{NA}^{2} \\
61,766 \\
79,000\end{array}$ & $\begin{array}{l}<1 \\
52\end{array}$ & $\begin{array}{l}20 \\
20\end{array}$ & $\begin{array}{l}2.6 \\
2.7\end{array}$ \\
\hline $\begin{array}{l}\text { Carmel Energy } \\
\text { Carter } \\
\text { Shell } \\
\text { Dotson Oil } \\
\text { Jones-Blair }\end{array}$ & $\begin{array}{c}\text { Allen Co., KS } \\
\text { Deerfield, MO } \\
\text { Vernon Co., MO } \\
\text { Vernon Co., MO } \\
\text { Stotsbury Fld., MO }\end{array}$ & Steam & $\begin{array}{l}1.5 \\
4 \\
2 \\
4 \\
5\end{array}$ & $\begin{array}{c}4,222 \text { est } \\
6,752 \\
6,600 \\
17,953 \\
133,018\end{array}$ & $\begin{array}{c}4.6 \\
12.3 \\
73\end{array}$ & $\begin{array}{c}16 \\
32 \\
32 \\
\mathrm{NA}^{2}\end{array}$ & $\begin{array}{l}7.8 \\
0.29 \\
.28 \\
0.384\end{array}$ \\
\hline $\begin{array}{l}\text { Carmel Energy } \\
\text { Mobil } \\
\text { Shell } \\
\text { Mobil } \\
\text { Currently operat }\end{array}$ & $\begin{array}{l}\text { Eastburn Fld., MO } \\
\text { Stephens Co., OK } \\
\text { Shovel-Tum Fld., OK } \\
\text { Cox Penn, OK } \\
\text { 1992): }\end{array}$ & Fireflood & \pm 2 & $\begin{array}{c}550,000 \\
\mathrm{NA}^{2} \\
\mathrm{NA}^{2} \\
\mathrm{NA}^{2}\end{array}$ & & $\begin{array}{c}95 \text { est } \\
20\end{array}$ & 1.32 \\
\hline Mobil & Stephens Co., OK & Steamflood & $>4$ & $\mathrm{NA}^{2}$ & $>250$ est & & \\
\hline
\end{tabular}

1 CDOR - Calendar day oil recovery.

2 NA - Not available.

3 BOPD/W - Barrels of oil per day per well. 
7. Injection pressures that exceed the reservoir fracturing pressure may cause environmental problems at the surface or in the subsurface if injected fluids or formation fluids escape.

8. Development of old fields with horizontal wells must carefully consider the geology and expected oil recovery to justify the increased expenditure. Horizontal wells for heavy oil recovery in the Cherokee Basin do not look economical because of the geology of the reservoir.

This report illustrates some of the lessons learned by operators who moved their heavy oil recovery operations to other parts of the world where the heavy oil is in reservoirs with unconsolidated or friable sandstone. It also shows why light oil production operators in the Midcontinent are marginally successful in drilling infill wells. Operators drilling infill wells typically encounter reservoir pressure above that of surrounding old wells and obtain flush production that rapidly declines to stripper levels, the results of reservoir compartmentalization. Each of the TEOR operations analyzed produced heavy oil but it is these authors opinion after looking at the Midcontinent and other U. S. Basins that there are much better reservoirs containing heavy oil that can be more economically produced with current technology than those occurring in the Midcontinent. The exception being the unconsolidated sand reservoirs in south central Oklahoma. It is in the unconsolidated sand formations and select consolidated formations where additional domestic heavy oil production is possible.

\section{BACKGROUND}

Heavy crude oil is defined as having gas-free viscosity, $>100$ and $<10,000$ MPas (centipoise, $\mathrm{cP}$ ) inclusive at original reservoir temperature or a density of $943 \mathrm{~kg} / \mathrm{m}^{3}\left(20^{\circ}\right.$ API gravity) to $1,000 \mathrm{~kg} / \mathrm{m}^{3}\left(10^{\circ} \mathrm{API}\right.$ gravity) inclusive at $15.6^{\circ} \mathrm{C}\left(60^{\circ} \mathrm{F}\right)$ and atmospheric pressure (Group, 1981). The current United States production of heavy oil is approximately 750,000 to 800,000 BOPD (Olsen, 1991) and accounts for $11 \%$ of the total daily oil produced (7.0 million BOPD). The daily production of heavy oil by TEOR is 461,000 BOPD (Moritis, 1992). The 1984 National Petroleum Council report suggests that with 1984 technology that thermal oil production would increase to about 1 million BOPD and 2 million with advanced technology by the year 2010 (NPC, 1984). This essentially calls for more than doubling the domestic heavy oil production or increasing TEOR at least threefold, a projection that is unprecedented in that it took nearly 30 years to develop California's TEOR industry to its current level. The present and projected energy situation in the United States is heavily oriented toward imported petroleum and use of "clean" domestically mined coal. Extraction technology directed toward both light and heavy oil production will become increasingly important to reduce the rate of decline of U.S. oil production. 


\section{Structure and Scope of the Study}

Recovery of heavy crude oil by steam is well established and successful method in several areas of the world. Some heavy oil is known to exist in certain locations of the Midcontinent region but the use of thermal methods to recover this oil has not commonly been applied. An interest in expanding domestic oil production led to this feasibility study. Consequently, a feasibility study was proposed to investigate the known heavy oil resources from available informational sources in Kansas, Missouri and Oklahoma; screen them for potential thermal applications; and evaluate various economic facets that may limit development of the resource.

The scope of this study includes (1) collect and compile a listing and description of heavy oil resources from the Midcontinent using publicly available information, (2) determine the capabilities of refineries in this area to refine additional heavy oil that may result form an increase TEOR production, and (3) screen reservoirs data collected in determining the potential for applying TEOR or other EOR techniques to recover additional heavy oil. As the project progresses, it was realized that sufficient reservoir data (subsurface control and other data on these heavy oil deposits were sparse and fragmentary resulting in wide ranging resource base estimates and were not available to perform detail screening based on established screening criteria. Therefore, limited geological information and experience of prior TEOR pilots were relied upon heavily in this study to estimate recoverable resource and the constraints to production.

Most previous studies on heavy oil deposits in Kansas, Missouri, and Oklahoma have concentrated on only a few counties in each state near or including outcrop areas of Cherokee Group, Desmoinesian Stage, Middle Pennsylvanian System (age) heavy oil-impregnated sandstones or in the Arbuckle Mountains of south-central Oklahoma. This study includes former areas of investigation but also encompasses other heavy oil deposits and production that have been reported or are being reported on an annual basis in these states. Accumulations of heavy oil in producing and nonproducing accumulations in reservoir rocks from Cambrian through Pennsylvanian age within several different sedimentary basins in the study area were examined. .

Proprietary, DOE/industry-funded, and DOE-funded pilot-scale and full field-scale TEOR. projects for heavy oil recovery in the study area have been analyzed for causes of success or failure of the project. Success and/or failure of selected processes and projects were compared to successful TEOR projects in California, Canada, Venezuela, and Indonesia.

Chapters 2, 3 and 4 discussed the geology of the resource documented in the literature. Some previous studies have considered heavy oil as oil with API gravity as $<25^{\circ}$ API while other authors did not qualify their term of "heavy oil." Therefore, many of the formations analyzed in this report were found to produce medium crude oil, $>20^{\circ}$ API and $<30^{\circ}$ API. The number of reservoirs with medium gravity oil in the Midcontinent is at least twice that of heavy oil. To evaluate the feasibility of recovering these resources by TEOR, information on depositional 
heterogeneity's such as discontinuous compartments, clay distribution and laminated parallel bedding, diagenetic heterogeneities (cementation, dissolution, clay deposition etc.) and structural heterogeneities (dip angle, faults and fractures) were collected. The effects of these heterogeneities on TEOR efficiency and oil recovery were evaluated.

Based on the results of previous EOR projects in Kansas, Missouri and Oklahoma, the economics of TEOR projects in different parts of the projects area were studied in Chapter 5, the geologic factors affecting the economics were also discussed. The advantages and disadvantages of using horizontal and infill wells in recovering additional oil from heavy oil reservoirs in Kansas, Missouri and Oklahoma were examined in Chapter 6, and the environmental considerations in applying TEOR in the Mid-continent states we:e discussed in Chapter 7. Refining capacities and the pipeline transportation network can have an in pact on heavy oil recovery potential in a project area and are discussed in Chapter 8. Chapter 9 summarized the important conclusions and recommendations of this study. Finally, information on the heavy oil reservoirs in the Midcontinent area and their properties were tabulated in Chapter 10.

\section{Geology of Some Midcontinent Reservoirs}

Since the authors contend that the major limiting factor in developing the heavy oil resources of the Midcontinent is the geology of the reservoir and not the oil recovery process, an explanation of some aspects of the geology of Pennsylvanian age (300 million years old), fluvial and deltaic reservoirs in relation to thermal recovery of heavy oil is required. This analysis is not limited to heavy oil since heavy and light oil reservoirs are found in the same reservoir rocks of the same age and depositional environment, where during the course of time some of the light oil was water washed, biodegraded or lighter hydrocarbons escaped to form a heavy oil. One example is the Bartlesville sandstone, a Cherokee Group, Desmoinesian Series, Middle Pennsylvanian System (age) fluvial-dominated deltaic deposit, commonly found as a reservoir rock for both heavy and light oil in the study area.

Cherokee Group sandstones in the Cherokee and Forest City basins were deposited in a fluvial deltaic environments as shown in Fig. 1.1 (Willhite, 1986; Pettijohn, Potter and Siever, 1972; Allen, 1965). These sandstones are dominated by channel filling, multi-storied, discontinuous, fining-upward, multiple-pointbars deposited in channels cut into underlying older Pennsylvanian and/or Mississippian rocks. Channels where these sandstones were deposited were commonly no larger than about one-fourth mile in width at any given time. Many Cherokee Group fields are much wider than one-fourth mile at present, due to lateral accretion of the pointbar deposits as the stream meandered across the flood plain, but were probably no larger then about one-fourth mile at any given time during their depositional history. 


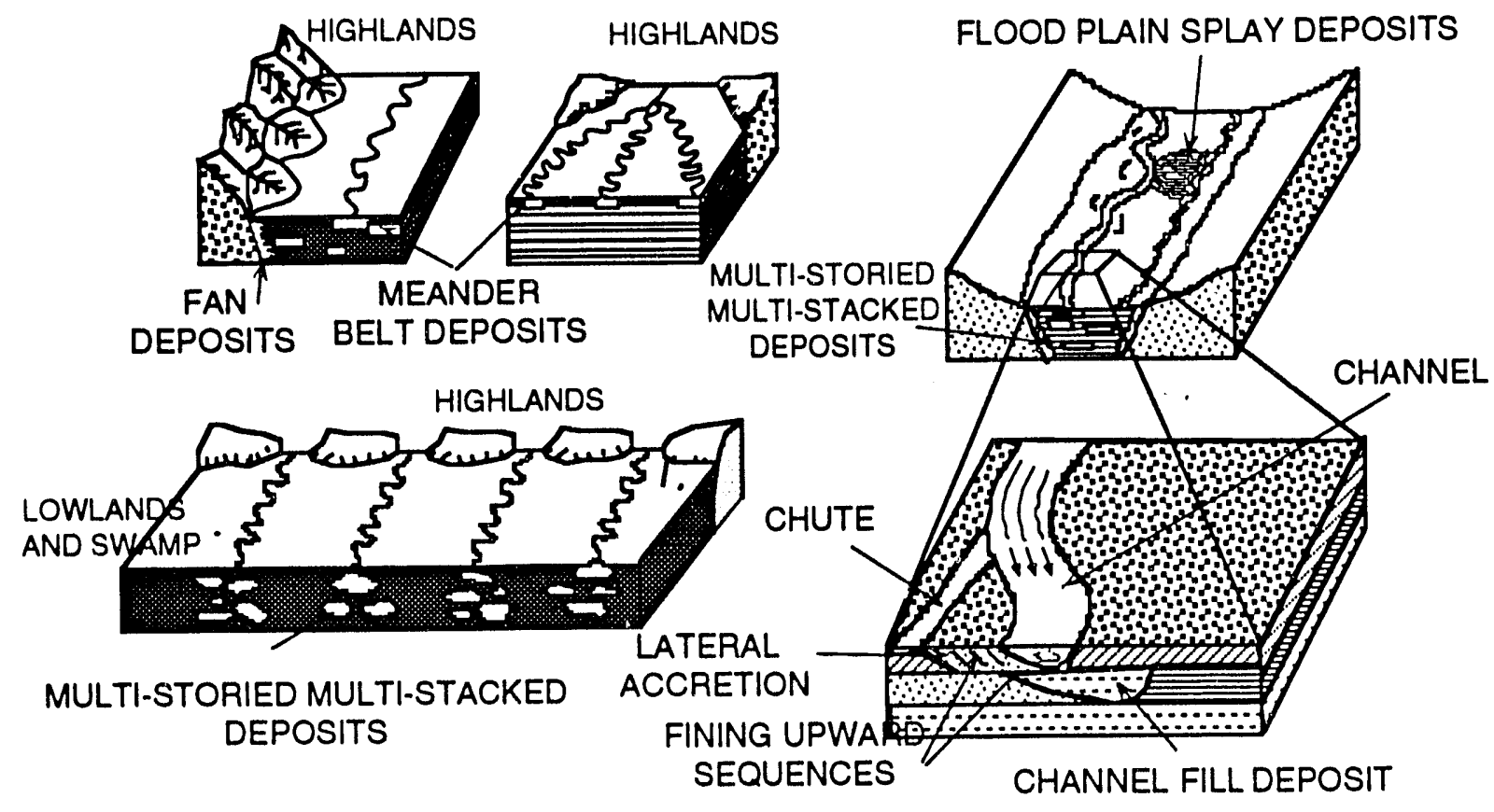

FIGURE 1.1 - Fluvial and deltaic depositional environment showing geometry of meandering channel deposits, multi-storied channel deposit (after Allen, 1965).

Many of the Pennsylvanian Cherokee sandstones that form current Midcontinent oil reservoirs were deposited as fluvial deltaic reservoirs in lower alluvial valleys or on deltaic coastal plains by streams or distributaries whose channels cut into and were confined by unconsolidated sediments. Many of the Midcontinent reservoirs were fluvial and had straight unbraided courses (as opposed to the braided or meandering steams, Fig. 1.1) and had relatively little bedload and thus are not massive or thick sands. Ultimate recovery of oil from reservoirs in Cherokee Group sandstones is affected by facies type, small scale sedimentary structures, bedding boundary and intergranular small-scale permeability barriers, and diagenetic changes, (internal architecture) commonly identified as "heterogeneities", within the sandstone body. The scale of the barriers is shown in Fig. 1.2, A through F (Allen, 1965). With consolidated sediments, many of these small scale barriers (low permeability bedding boundaries) may be sealing. In contrast, in unconsolidated sands these small barriers may be breached by an oil recovery process producing significant oil. The Tertiary age (65 to 5 million years in age) unconsolidated sands are the major heavy oil producing reservoirs of California, Canada or Venezuela. The dynamics of channels formation in unconsolidated sediments is well known and predictable based on modern hydrology (Leopold, Wolman and Miller, 1964; Swanson, 1981, Swanson, 1981, Swanson, 1992; 


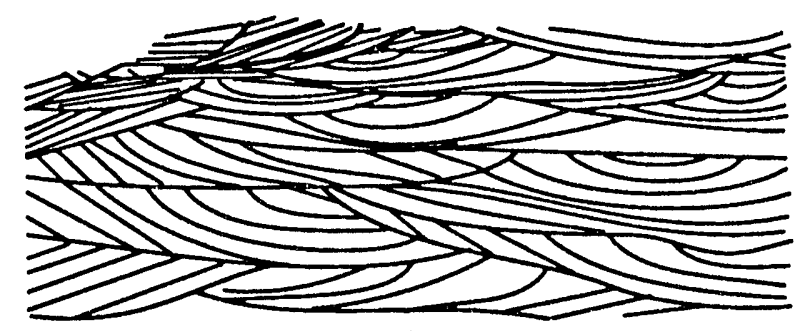

$0 \mathrm{ft} .3$
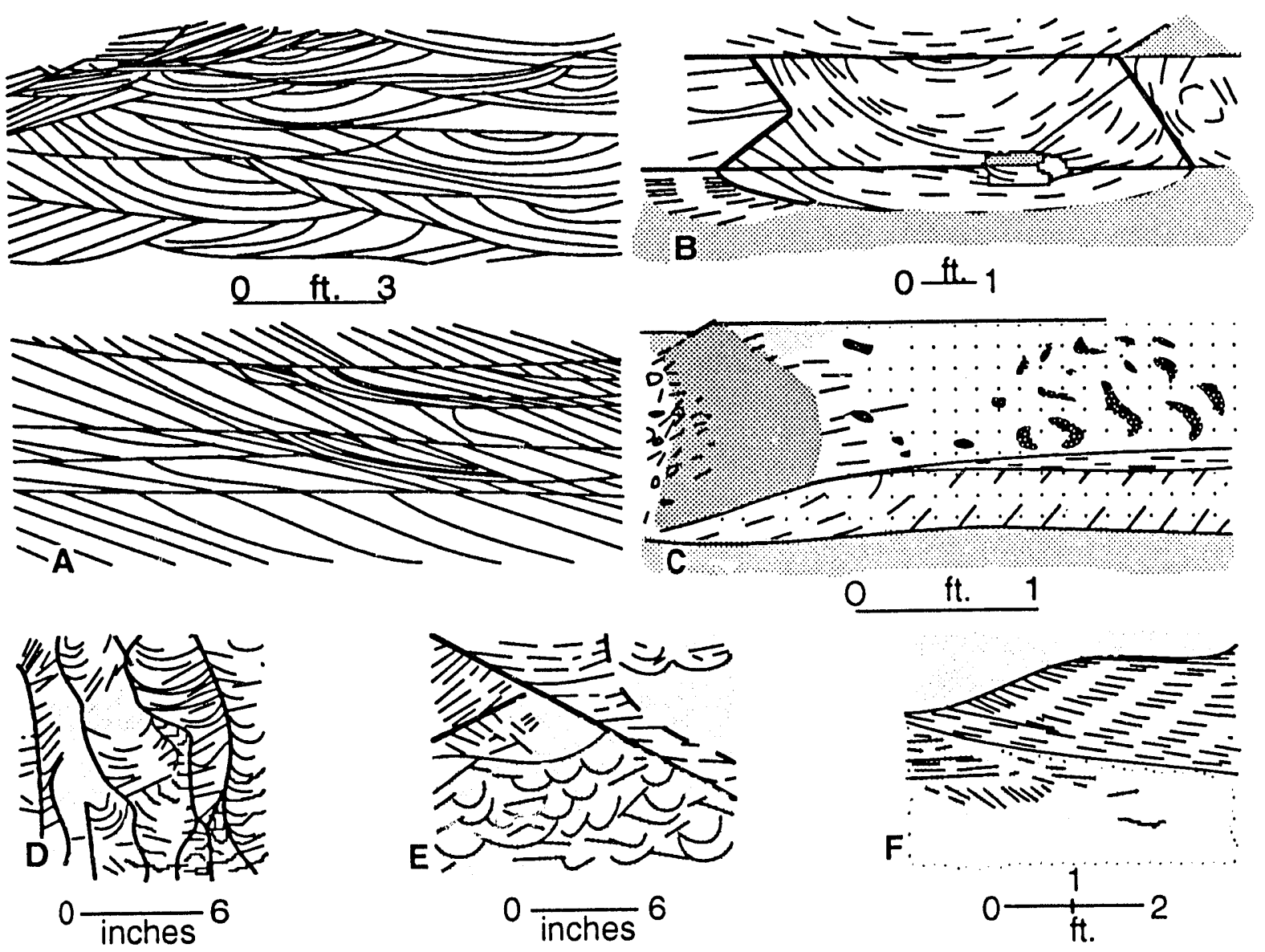

FIGURE 1.2 - Small scale permeability barriers found in pointbars (sediment deposited on the inside of a meander loop) as part of fluvial deltaic deposit (from Allen, 1965). A. Large scale trough bedded cross-stratification in vertical sections perpendicular (upper diagram) and parallel (lower diagram) to flow. B. Large scale trough bedded cross-stratification in horizontal and vertical section looking down current. C. Large scale planar bedded cross-stratification in large scale ripple. D. Small scale trough bedded cross-stratification in horizontal section. E. Small scale trough bedded cross-stratification in section perpendicular to flow. F. Flat-bedded sand in vertical section.

Pettijohn, Potter and Siever, 1972). Many of the features of pointbar deposits (sediment deposited on the inside of meander loop) are shown in Fig. 1.3.

Lower sandstone facies (e.g., lower channel fill or pointbar) will probably have the largest volume of economically recoverable oil during primary, waterflood, and/or EOR phuses of production. Upper sandstone facies (e.g., upper channel fill or pointbar) that are part of the oil reservoir will contribute small quantities of oil throughout the productive life of the reservoir and be produced on a less cost-effective basis. Figure 1.4 shows a conceptual model of progressively increasing complexity of a Midcontinent stream channel illustrating the facies described. The central injector, shown in Fig. 1.5 when completed open hole or perforated over the entire sand is 


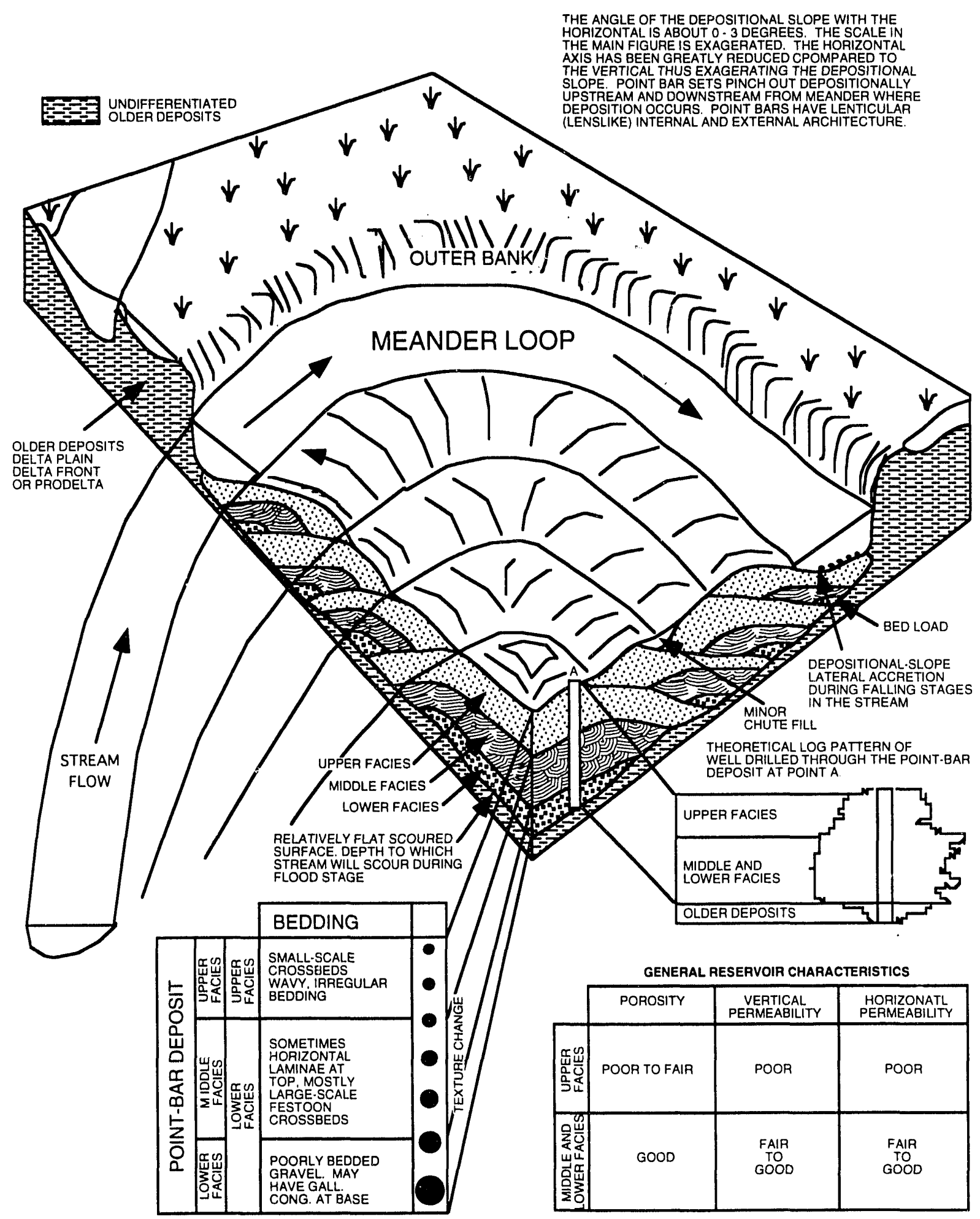

FIGURE 1.3 - Pointbar deposit-common depositional environment for Pennsylvanian Age petroleum reservoirs of the Midcontinent (Modified from Swanson, 1983). 

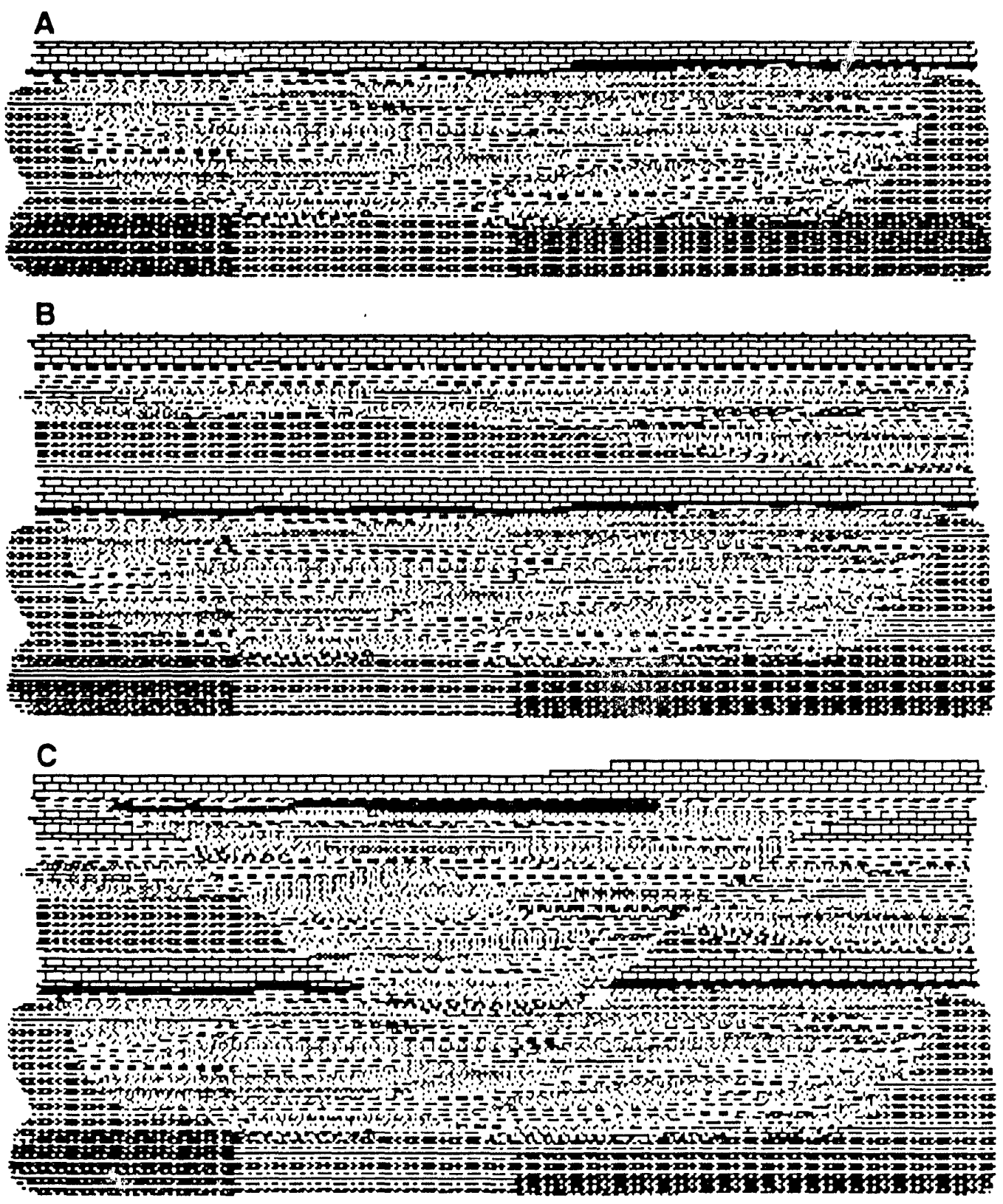

\begin{tabular}{|c|c|c|c|c|c|}
\hline 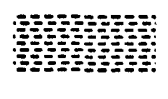 & SHALE & 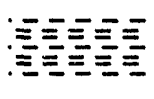 & $\begin{array}{l}\text { CHANNEL-FILL } \\
\text { SHALE }\end{array}$ & $\%$ & $\begin{array}{l}\text { FINE-GRAIN } \\
\text { SANDSTONE }\end{array}$ \\
\hline in & $\begin{array}{l}\text { SANDY } \\
\text { SILT }\end{array}$ & 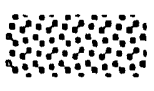 & CONGLOMERATE & 贾 & LIMESTONE \\
\hline BE:EE & SILT & & COAL & & $\begin{array}{l}\text { COARSE-GRAIN } \\
\text { SANDSTONE }\end{array}$ \\
\hline
\end{tabular}

FIGURE 1.4 - Conceptual Model of Progressive Development of a channel-fill depositional complex. A is early stage of development and $B$ and $C$ are later stages, more complex development of a multi-storied reservoir sequence. 


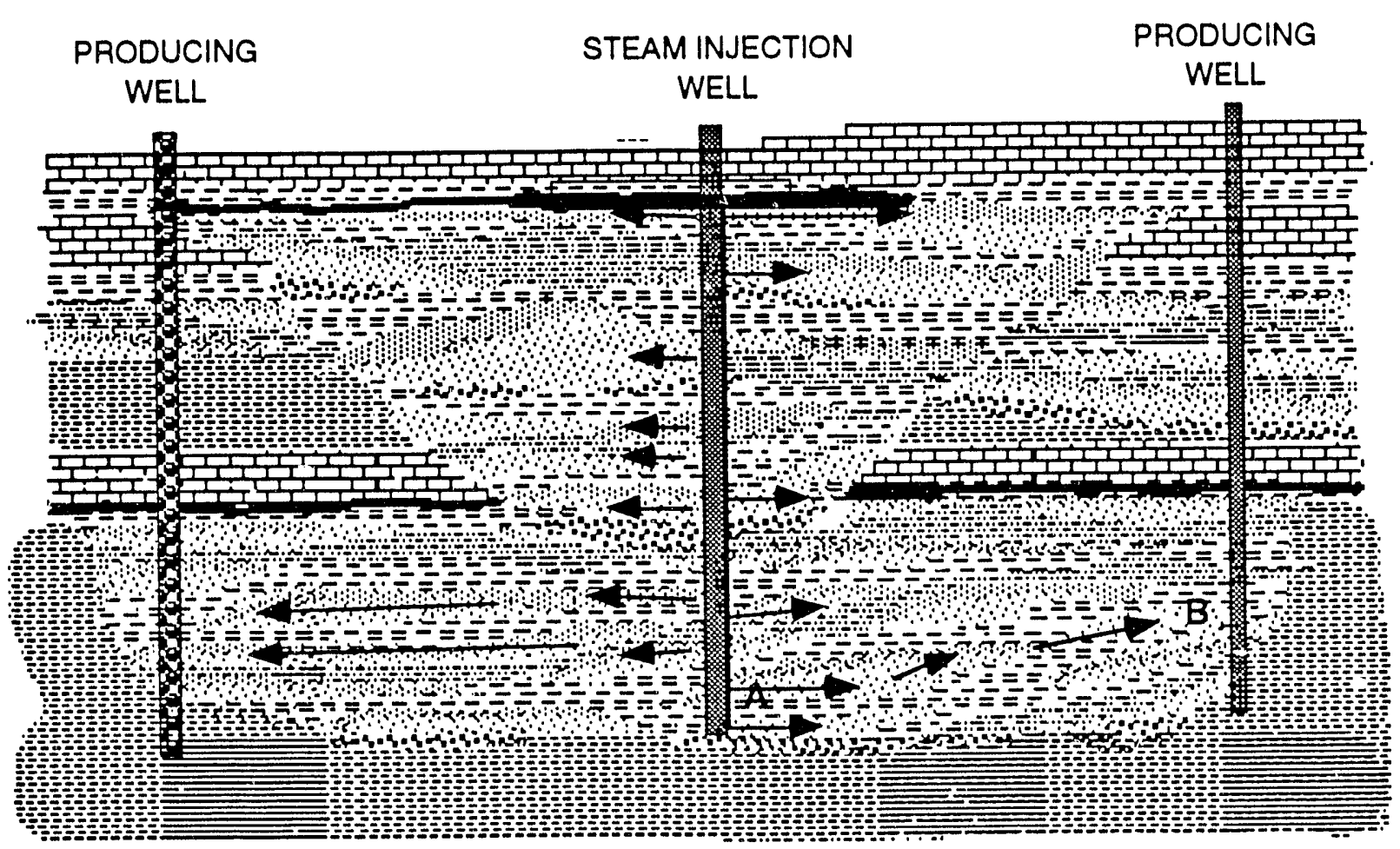

FIGURE 1.5 - Schematic cross section of a pointbar with steam injection into center well and path of steam sweeping those continuous sands but much of the reservoir has compartments uncontacted. For explanation of symbols see figure 1.4.

exposed to numerous sand bodies but only the lower facies is connected to the producing well on the left of the figure. Two sands (lower facies shown as "A" and a high permeability sand in an upper facies "B" connect) are in communication between the injector and the producing well on the right. The implication for fluid flow between the entire injector and producer(s) is that only a small fraction of the reservoir is swept. Drilling infill wells between current injector and producing wells will allow more contact between continuous sand bodies and may yield higher recovery. Determination of the spacing necessary to contact and drain the sand bodies is critical. The economics of infill drilling on close spacing must be carefully analyzed beciause oil production may not be enough for payout and an economic rate of return.

Figure 1.4C shows two sand-filled stream channels typical of Midcontinent fluvial deltaic upper point bar facies that commonly contain oil entrapped in discontinuous depositional compartments. This compartmentalization is affected by both depositional conditions and diagenetic changes. Depositional compartmentalization caused by sandstone lenses commonly have spatial variation smaller than the prevailing Midcontinent oil field well spacing (5, 10, 20, or 4() acres). Spatial variation of depositional compartmentalization may be 1 acre or less. Bedding boundary and intergranular small scale permeability barriers are associated with depositional 
compartmentalization and may form sealing boundaries. Bedding boundary permeability barriers are formed by early, partial to almost complete, cementation and/or compaction of very-finegrained sediment (e.g. very-fine grained sand, silt or clay) deposited along sand lenses boundaries as shown in Fig. 1.2. Small-scale intergranular permeability barriers may be formed by precipitation of diagenetic clays or by clay or shale pebbles deposited with sandstone grains. Depositional compartmentalization and bedding boundaries and small-scale intergranular pcrmeability barriers are commonly noted as reservoir "heterogeneities," a generic non-specific descriptive term.

A schematic of thin (a few inches to a few feet thick), laminated parallel bedded sandstone is shown in Figs. 1.2, 1.3 and 1.4, which may be present in an upper facies of a point bar. If parallel bedded sandstone has porosity, permeability, and oil saturation as good as that of lower facies of a point bar, oil may be swept by secondary and EOR processes from this zone. Parallel bedded sandstone may also act as a "thief" zone (zone where fluids can flow faster) for waterflood or enhanced waterflood operations, creating a direct path between wells. Direct communication (fluid flow path) is created because of the continuous permeability path between wells in parallel bedded sandstone, in contrast to discontinuous permeability paths between wells in depositional compartmentalized sandstone. If permeability is continuous between wells, the sweep efficiency should be significantly higher. If permeability is discontinuous between wells, as with depositional compartmentalized sandstone, sweep efficiency will be poor to nonexistent. This "bypassed" or "unswept" oil in depositionally compartmentalized sandstone is often targeted by infill wells. Drilled late in the life of a Cherokee Group sandstone field, an operator may complete "good" oil producing wells. These wells commonly last a few days to a few weeks before they are producing at stripper levels of 0.5 to 2 BOPD. These wells may be economical and pay out in months to years, depending on the rate of decline. If the "good" oil producing well has been completed in an upper facies, with extensive depositional compartmentalization (highly compartmentalized) in the oil reservoir, payout may be in a few months, years, or never depending of the relationship of the well spacing to the size of compartments. Vertical infill wells for development (recovery) of the "unswept" oil resource entrapped in depositional compartments may not be economical.

Horizontal wells will encounter the same problems as vertical infill wells. Therefore, horizontal well technology with present completion technology may not be the solution for recovering depositionally compartmentalized oil when compartments are smaller than a certain size or whose geometry is adverse. Well stimulation by hydraulic fracturing with a proppant will create a vertical fracture (principal direction of $\pm N E-S W$ in the Midcontinent), tending to be aligned parallel to the direction of least principal stress, when implemented in reservoirs deeper than about $1,000 \mathrm{ft}$. These fractures, created by hydraulic fracturing, will contact a limited number of 
compartmentalized sandstone lenses or the same compartments in which a well is located. This offers a temporary solution for increasing oil recovery since fracturing will have the same problems as a vertical well perforated in upper point bar facies.

The lower trough horizontally cross bedded facies of Cherokee Group sandstones will have the best potential for oil recovery. Trough cross bedded sandstone is generally fine- to mediumgrained cemented quartz sand with less depositional compartmentalization. These facies are more continuous and less "heterogeneous" than the upper point bar facies. When waterflooding and enhanced waterflooding are implemented in the lower facies, oil will be swept between wells from injector to producer. This facies is preferentially swept by injected fiuids because the lower facies has more continuous favorable porosity and permeability which allows for better sweep efficiency. A direct path is sometimes developed in. lower channel fill or point bar facies reservoir rocks because they have more permeable sands unevenly distributed across the reservoir aligned in the direction of the source of sediments. This may be recognized by early breakthrough of injected fluids in lower facies or thin parallel bedded the upper point bar facies. The lower channel fill facies reservoir rock may have porosity, permeability, and oil saturation equal to or greater than upper facies. Oil from an upper facies is sometimes produced by imbibition through secondary and enhanced waterflooding. Wells producing small quantities (0.2 to 2 BOPD) of oil after 40 to 50 years of waterflooding are probably producing oil by imbibition or gravity drainage through fractures from an upper facies.

\section{Heavy Oil and Light Oil Reservoirs in the Same Depositional Environment}

The difference between light oil reservoirs and heavy oil reservoirs is the gravity and viscosity of the oil. Numerous operators in the Cherokee Basin and throughout the Midcontinent make their living by drilling and producing light oil. They encounter nearly original reservoir pressure when they drill these wells and obtain flush oil production. Oil production and pressure decline rapidly and wells become strippers within weeks to months but there is usually enough production to pay for operations. A major lesson that can be learned from this study is that the geology of the reservoir controls production in many of these Midcontinent reservoirs. The new oil contacted by infield drilling is entrapped by depositional compartmentalization (internal architecture as described by Johnson and Olsen, 1991; Willhite, 1986; and Walton, et al, 1986). Discontinuous, channel-filling, multiple-stacked pointbar, fluvial deltaic sandstones with bedding boundary and intergranular permeability barriers due to stream deposition and diagenetic changes are the reservoir rock for both heavy and light oil reservoirs in much of the Midcontinent. Production problems of incomplete drainage ("bypassed oil" or "unswept oil") of light and heavy oil reservoirs in Midcontinent fluvial deltaic sandstones are caused by depositional compartmentalization (internal architecture). 


\section{BIBLIOGRAPHY}

Allen, J. R. L. A Review of the Origin and Characteristics of Recent Alluvial Sediments, Sedimentology, v. 5, 1965, p. 191.

Barwis, H. H., J. G. McPherson and J. R. J. Stadlick. Sandstone Petroleum Reservoirs, Springer-Verlag, New York, NY, 1990.

Broussard, Martha Lou (Ed). Deltas models for exploration, Houston Geological Society, Copyright 1975.

Group of Experts. UNITAR Proposal for the Definition of Heavy Crude and Tar Sands and Addendum, Second International Conference on Heavy Oil and Tar Sands, Caracas, Venezuela, February 1981.

Johnson, W. I. and D. K. Olsen. Midcontinent Fluvial Depositional Environments and Their Influence on Enhanced Oil Recovery. Pres. at Petroleum-Reservoir Geology in the Southern Midcontinent Workshop, Univ. of Oklahoma, Mar. 26-27, 1991.

Johnson, W. I. and D. K. Olsen. Midcontinent Fluvial Depositional Environments and Their Influence on Enhanced Oil Recovery. In Petroleum-Reservoir Geology in the Southern Midcontinent, Ed. by K. S. Johnson and J. A. Campbell, Oklahoma Geologic Survey, Circular 95, 1993.

Leopold, L. B. and T. Maddock. The Hydraulic Geometry of Stream Channels and some Physiographic Implications. U.S. Geologic Survey Prof. Paper 252, 1953.

Leopold, L. B. , M. G. Wolman and J. P. Miller. Fluvial Processes in Geomorphology, Freeman, San Francisco, 1964.

Moritis, G. Biennial EOR Review, EOR Increases $24 \%$ Worldwide; Claims $10 \%$ of U.S. Production. Oil \& Gas. J., v. 99, No. 16, Apr. 20, 1992, pp. 51-79.

National Petroleum Council, Enhanced Oil Recovery Report, National Petroleum Council, June 1984, p 77.

Olsen, D. K., W. I. Johnson and E. B. Ramzel. Feasibility Study of Heavy Oil Recovery in the Lower 48 States, Department of Energy Report No. NIPER-521, January 1991.

Olsen, D. K. and W. I. Johnson. Feasibility Study of Heavy Oil Recovery in the Midcontinent Region. Pres. at Petroleum-Reservoir Geology in the Southern Midcontinent Workshop, Univ. of Oklahoma, March 26-27, 1991.

Pettijohn, F. J., P. E. Potter and R. Siever. Sand and Sandstone, Springer-Verlag, New York, New York, 1972.

Schumm, S. A., P. M. Mosley, and W. E. Weaver. Experimental Fluvial Geomorphology, John Wiley and Sons, New York, NY, 413 pp.

Shirley, Martha Lou and James A. Ragsdale (Eds.) Deltas in their geologic framework, Houston Geological Society, Copyright 1966.

Swanson, D. C. Deltaic Reservoir Handbook, Lafayette Geol. Soc. and Swanson Consulting Services, 1981, 100 pp. 
Swanson, D. C. Meandering Stream Deposits, Swanson Petroleum Enterprises, 1981, 30 pp.

Walton, A. W., D. J. Bouquet, R. A. Evenson, D. H. Rofheart, M. D. Woody. Characterization of Sandstone Reservoirs in the Cherokee Group (Pennsylvinian, Desmoinesian) of Southeastern Kansas. In: Reservoir Characterization, Edited by L. W. Lake and H. B. Carroll, Jr., 1986.

Willhite, G. P. Waterflooding. SPE Textbook Series Volume 3, Society of Petroleum Engineers, Richardson, TX, 1986, pp. 240-301. 


\section{CHAPTER 2}

\section{HEAVY OIL OCCURRENCE AND INTEGRATED ANALYSES OF GEOLOGY AND ENHANCED OIL RECOVERY PROCESS APPLICATIONS IN KANSAS}

\section{SUMMARY}

Heavy oil is found in shallow low permeability $(<500 \mathrm{mD})$ consolidated sandstone formations in southeastern Kansas and in carbonates in central and western Kansas. These sandstones were principally deposited as meandering stream channels. They occur as narrow elongated fields and are often found parallel to light oil reservoirs of the same geologic age. The geologic age of most Midcontinent oil producing formations is Pennsylvanian (310 million years) and older. Time has allowed for extensive diagenesis whereas many heavy oil producing sands of California, Canada and Venezuela are tertiary ( $<66$ million years) where far fewer changes to the formation occurred. Reservoir rock is highly compartmentalized and fractured. Fracture alignment is generally in a northeast-southwest direction with the secondary fractures in a perpendicular direction. Surface fractures are an excellent indication that reservoir rock and confining beds are also fractured. Small volumes of heavy oil ( $<0.3 \mathrm{BOPD})$ are obtained by primary production from these sandstone reservoirs. TEOR methods, cyclic steam, steamflooding, steam and combustion gas, and in situ combustion have proven that the oil can be recovered using close spaced wells $(<250 \mathrm{ft})$ in sandstone reservoirs. The heavy oil of the carbonate reservoirs of central and western Kansas have seen little development because of the difficulty in producing high viscosity oil from tight carbonate formations even though they can have a high oil saturation. However, none of the projects reported look to be economically and environmentally acceptable.

An analysis of published data indicates that many previous reports considered heavy oil as oil up to $25^{\circ}$ API. However, it is seldom defined within the report. Major companies had large acreages under lease in southeast Kansas during the heavy oil boom of the 1960s. Shell had as much as a million acres under lease. There has been a driving force for companies to lease properties, and there has to be reasons for them to release the acreage. Much of the driving force to lease acreage is the strong belief that in situ combustion could be widely applied, that steam could also be used to recover heavy oil, and that the heavy oil belt of southeast Kansas, western Missouri, and northeast Oklahoma was continuous. In situ combustion has proven to be one of the most difficult EOR technologies to control. Steam has proven to be a very efficient oil recovery process but not in tight, fiesh water sensitive, fractured sandstone formations. Many times, well spacing required for effective steam sweep of these Midcontinent reservoirs is less than one acre and recovery may cost more than the original oil-in-place is worth. Although heavy oil shows up in various fields and is behind casing in a lot of wells drilled to tap deeper light oil, the geology of the Pennsylvanian sands is predominantly that of fluvial dominated deltaic deposits. These sands are not large broad, widespread, blanket, sand deposits as originally believed. Analysis of major 
companies findings (geologic and thermal oil production) experience showed that better response (economic oil production) could be achieved from thicker, unconsolidated or friable sandstone formations, which were usually younger Tertiary in age. These formations are common in California, Venezuela, Canada, and Indonesia, sites of the majority of current thermal heavy oil production.

\section{BACKGROUND}

Prior studies on heavy oil occurrence in Kansas have concentrated on three southeastern counties, Cherokee, Crawford, and Bourbon. Occurrences of heavy oil have been found in these counties at shallow depths and in outcrop in some sandstones of the Cherokee Group, Desmoinesian Stage, Pennsylvanian System (Figs. 2.1 and 2.2). This study takes into account occurrences of heavy oil in reservoirs of all ages throughout the state of Kansas rather than concentrating on the same areas that have been investigated thoroughly in the past for occurrences of heavy oil. In Kansas, oil occurs and is being produced from reservoirs found in Precambrian fractured basement rocks, as well as in sandstone and carbonates from Cambrian through Pennsylvanian in age (Fig. 2.3) (Newell, et al., 1987). Descriptions of heavy oil impregnated reservoir rocks will be given in order of age.

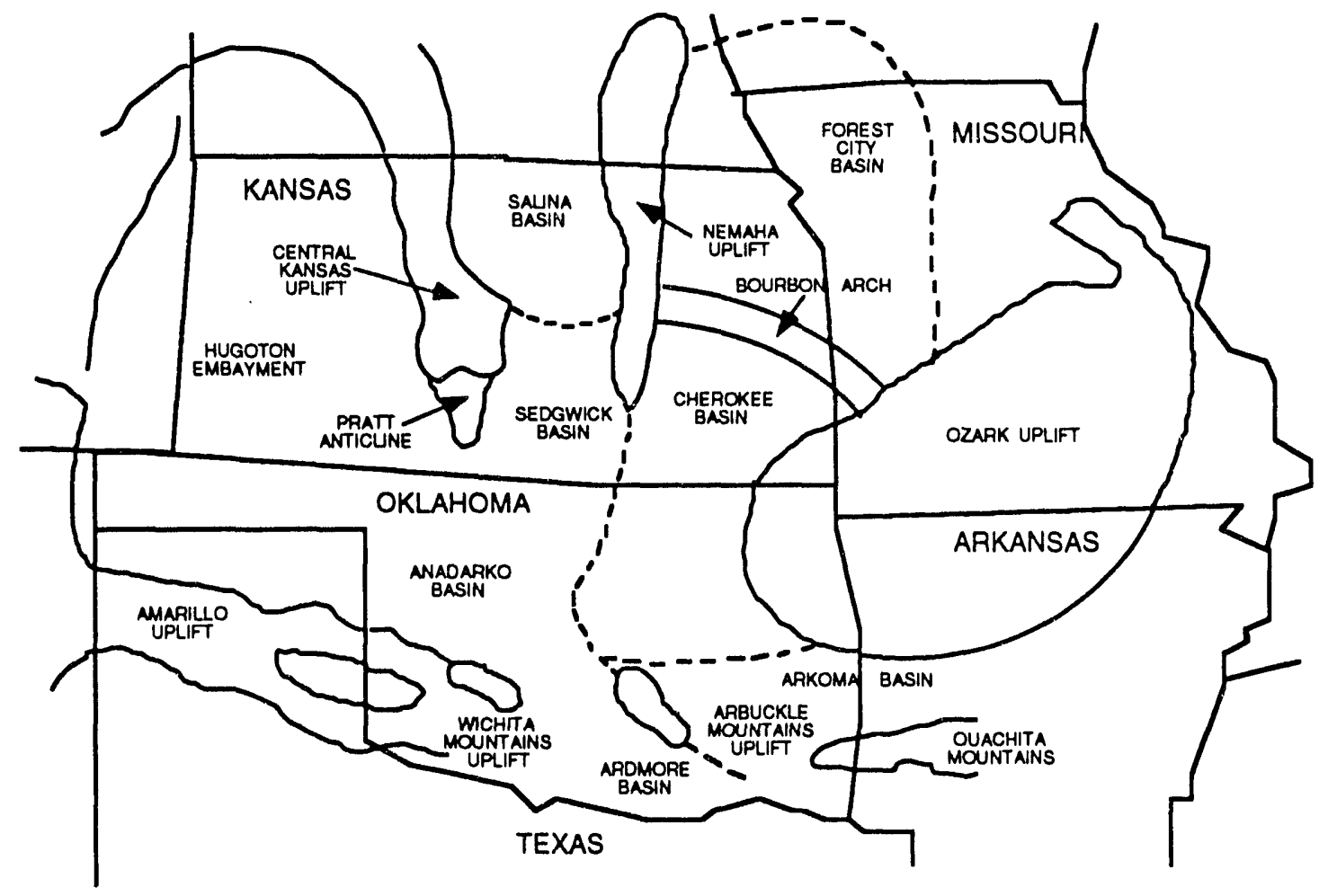

FIGURE 2.1. - Southern Midcontinent Basins. 


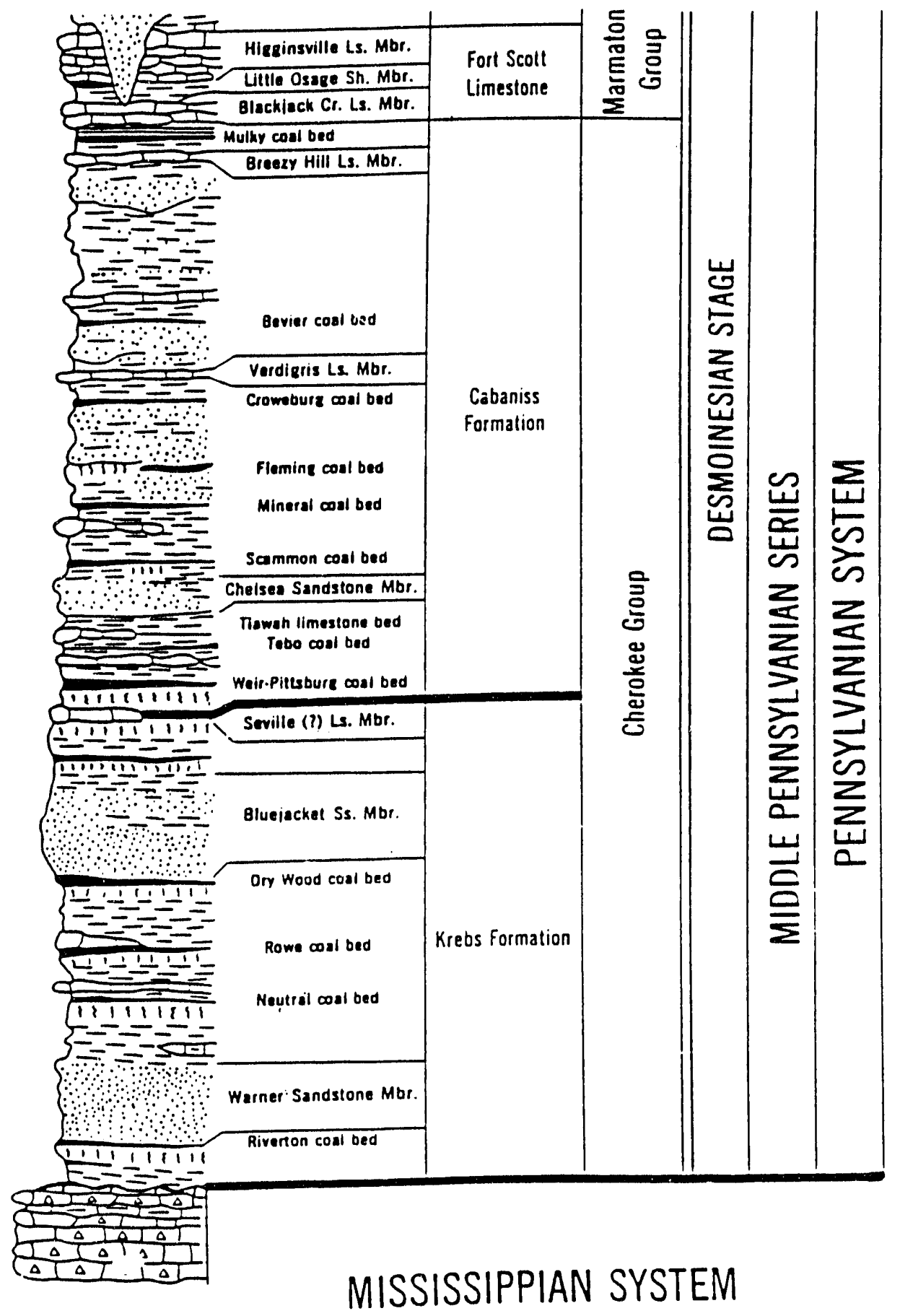

FIGURE 2.2. - Formal Stratigraphic Classification of the Cherokee Group (from Staton, 1987). 


\begin{tabular}{|c|c|c|c|c|c|}
\hline $\begin{array}{l}\text { TIME } \\
\text { MM } \\
\text { YEARS }\end{array}$ & ERA & PERIOD & SERIES & STAGE & $\begin{array}{c}\text { MANOR PETROLEUM } \\
\text { PRODUCING ROCK GROUP }\end{array}$ \\
\hline \multirow{2}{*}{1.6} & \multirow{2}{*}{ CENOZOIC } & QUATERNARY & & & \\
\hline & & TERTIARY & & & \\
\hline \multirow{3}{*}{$\begin{array}{l}66 \\
144\end{array}$} & \multirow{4}{*}{ MESOZOIC } & & UPPER & & NIOBRARA FORMATION \\
\hline & & CRETACEOUS & LOWER & & \\
\hline & & JURASSIC & & & \\
\hline 208 & & TRIASSIC & & & \\
\hline \multirow[t]{2}{*}{245} & \multirow{18}{*}{ PALEOZOIC } & \multirow{2}{*}{ PERMIAN } & & $\begin{array}{l}\text { CUSTERIAN } \\
\text { CIMARRONIAN }\end{array}$ & $\begin{array}{l}\text { SUMNER GROUP } \\
\text { COUNCIL GROVE GROUP }\end{array}$ \\
\hline & & & & GEARYAN & $\begin{array}{l}\text { CHASE GROUP } \\
\text { ADMIRE GROUP } \\
\text { WABAUNSEE GROUP } \\
\end{array}$ \\
\hline \multirow[t]{5}{*}{296} & & & & VIGILIAN & $\begin{array}{l}\text { SHAWNEE GROUP } \\
\text { DOUGLAS GROUP } \\
\text { LANSING GROUP }\end{array}$ \\
\hline & & & UPPER & MISSOURIAN & $\begin{array}{l}\text { KANSAS CITY GROUP } \\
\text { PLEASANTON GROUP } \\
\text { MARMATON GROUP }\end{array}$ \\
\hline & & PENNSYLVANIAN & MIDDLE & DESMOINESIAN & $\begin{array}{l}\text { CHEROKEE GROUP } \\
\text { "ATOKAN" ROCKS }\end{array}$ \\
\hline & & & & ATOKAN & "MORROWAN" ROCKS \\
\hline & & & LOWER & MORROWAN & "CHESTERAN" ROCKS \\
\hline \multirow[t]{2}{*}{320} & & & UPPER & $\begin{array}{l}\text { CHESTERAN } \\
\text { MERAMECIAN }\end{array}$ & \\
\hline & & MISSISSIPPIAN & LOWER & $\begin{array}{l}\text { OSAGIAN } \\
\text { KINDERHOOKIAN } \\
\end{array}$ & \\
\hline \multirow[t]{2}{*}{408} & & DEVONIAN & UPPER & & "UIINTON" IMESTONE \\
\hline & & & $\frac{\text { MIDDLE }}{\text { LOWER }}$ & & "HUNTON" LIMESTONE \\
\hline \multirow[t]{4}{*}{438} & & & UPPER & & \\
\hline & & SILURIAN & LOWER & & \\
\hline & & ORDOVICIAN & UPPER & & MAQUOKETA SHALE \\
\hline & & ORUUVIVIAT & MIDDLE & & $\begin{array}{l}\text { VIOLA LIMESTONE } \\
\text { SIMPSON GROUP }\end{array}$ \\
\hline \multirow{3}{*}{505} & & & LOWER & & ARBUCKLE GROUP \\
\hline & & & UPPER & & —BONNETERRE DOLOMITE \\
\hline & & CAMERIAN & $\begin{array}{l}\text { MIDDLE } \\
\text { LOWER }\end{array}$ & & REAGAN SANDSTONE \\
\hline 570 & PRECA & AMBRIAN & \multicolumn{2}{|c|}{ PRECAMBRIAN } & PRECAMBRIAN \\
\hline
\end{tabular}

FIGURE 2.3. - Geologic Timetable and Kansas Rock Chart Showing the Various Producing Zones Considered in this Report (from Newell et al., 1987). 
Drilling for petroleum in Kansas is reported to have started in 1860 , only one year after Colonel Drake's well first produced oil near Titusville, Pennsylvania. A site in the Forest City Basin of eastern Kansas in Miami County near Paola was the location of the first efforts in Kansas to find commercial oil production (Haworth, 1908; Jewett, 1954). By 1884, Paola was supplied with gas piped in from a nearby field. Sporadic drilling found minor amounts of oil and gas, but the first significant commercial oil field in Kansas was developed near Neodesha in 1893 (Owen, 1975). Light oil was of commercial value, gas was often flared due to low price, and heavy oil was not commercial.

Heavy oil is found in some Cherokee Group sandstones and limestones. Ockerman (1932) described the occurrence of heavy oil in sandstones and limestones in eastern Kansas that were being mined in open pit quarries for use by the highway department for paving roads (Figs. 2.4 and 2.5).

\section{RESULTS AND DISCUSSION}

\section{INTRODUCTION}

Geology of Paleozoic heavy oil producing formations will be discussed in this section (Fig. 2.3). Over 60 heavy oil reservoirs that produce from sediments of Cambrian through Pennsylvanian ages have been identified in Kansas. It is believed that all heavy oil reservoirs in

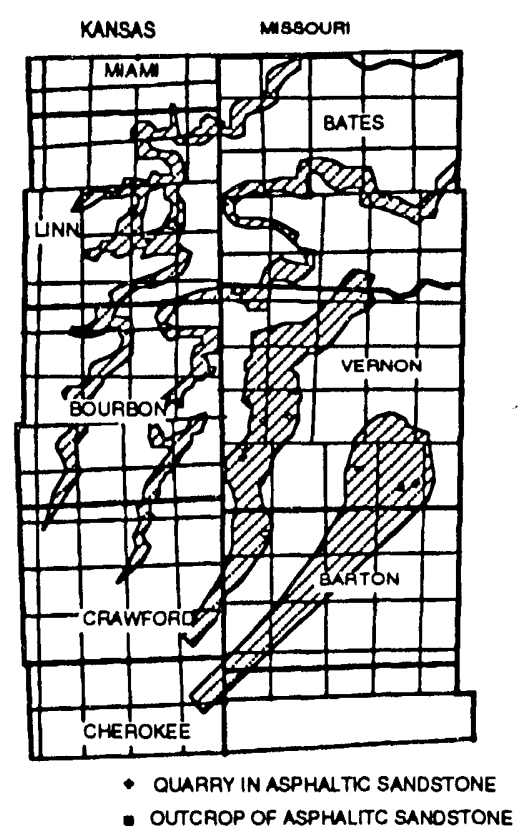

FIGURE 2.4. - East Kansas Asphaltic Sandstone Outcrops and Quarries (from Okerman, 1932). 


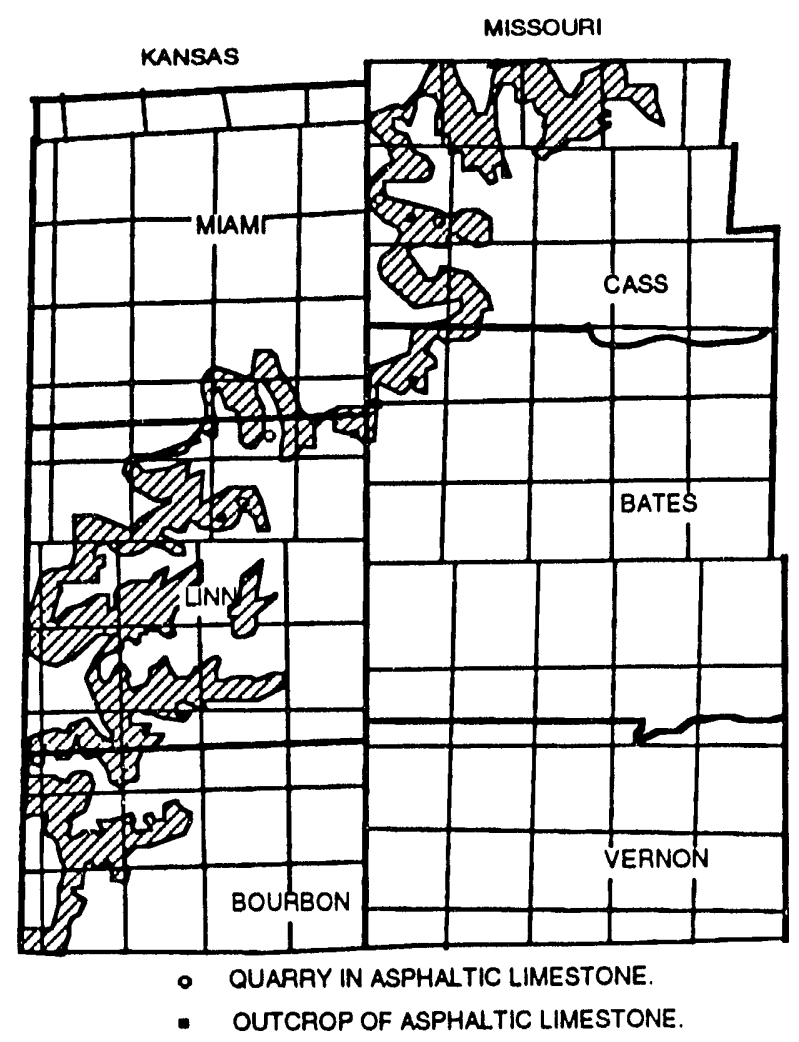

FIGURE 2.5. - East Kansas Asphaltic Limestone Outcrop and Quarries (from Okerman, 1932).

the state have not been identified in this report because Goebel (1966) reported that over 100 reservoirs produce heavy oil in Kansas. Goebel did not define heavy oil, but his definition is believed to be oil $<25^{\circ} \mathrm{API}$ gravity. Evidence that all producing heavy oil reservoirs are not listed in the Kansas Geological Survey Oil and Gas Production Reports is that a producing heavy oil reservoir in eastern Paola Field was identified in a conversation and visit with Lester Town, owner of Town Oil Company (1990). Because this heavy oil reservoir was not identified in published data on oil and gas production records, it is believed, but difficult to prove, that other heavy oil reservoirs exist in eastern Kansas, in known oil fields that are producing lighter API gravity oil (Fig. 2.1). Reservoir rock descriptions are given in ascending order from oldest to youngest, Cambrian to Tertiary. 


\section{GEOLOGY}

\section{CAMBRIAN PERIOD}

\section{Reagan Formation}

The Reagan Sandstone is a formation of Cambrian age that produces heavy oil in Kansas (Fig. 2.6). Annual oil and gas reports compiled and published by the Kansas Geological Survey list two oil fields that produce heavy oil from the Reagan Sandstone.

Reservoir quality rocks of the Reagan Sandstone average 40 feet $(12 \mathrm{~m})$ in thickness (Fig. 2.7) (Goebel, 1968). The dominant types of Reagan Sandstone are quartzose sandstone, dolomitic sandstone, quartz-glauconite sandstone, arkose and feldspathic sandstone. They were deposited rapidly as a basal Paleozoic transgressive sandstone on a nearly flat surface sometimes directly on Precambrian basement (Figs. 2.8 through 2.10). Precambrian basement is composed of igneous, sedimentary, and/or metamorphic rocks which supplied much of the material found in the Reagan (Figs. 2.11 and 2.12). These source rocks greatly influencing composition and texture of the Reagan sandstone. Eolian (wind dominated transport) processes greatly influenced the supply, rounding of quartz grains, and distribution of quartz, mica, and feldspar to offshore areas where carbonate deposition was simultaneously occurring during deposition of sandstone. This basal Palenzoic sandstone may range from fine to coarse grained quartzose, arkosic, or feldspathic sandstone (McElroy, 1965 and Newell et al., 1987).

\begin{tabular}{|c|c|c|c|c|c|}
\hline \multirow{2}{*}{$\begin{array}{l}\text { TIME } \\
\text { MM } \\
\text { YEABS }\end{array}$} & & & \multicolumn{3}{|c|}{ ROCK-STRATIGRAPHIC UNITS } \\
\hline & SYSTEM & SERIES & $\begin{array}{c}\text { BASED ON CORRELATION WITH } \\
\text { SURFACE SECTIONS (KANSAS } \\
\text { GEOL.SURVEY BULL. 189) }\end{array}$ & LITHOLOGY & $\begin{array}{l}\text { COMMONLY USED } \\
\text { KANSAS GEOLOGISTS } \\
\text { TERMINOLOGY }\end{array}$ \\
\hline \multirow[t]{2}{*}{440} & \multirow{4}{*}{ ORDOVICIAN } & UPPER & MAQUOKETA SHALE & $\ddot{\prime \prime} \overline{-}=$ & MAQUOKETA SHALE \\
\hline & & MIDIF & VIOLA LIMESTONE & 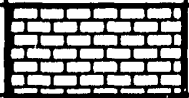 & VIOLA LIMESTONE \\
\hline \multirow[t]{4}{*}{470} & & (1) & SIMPSON GROUP & $-\infty$ & SIMPSON GROUP \\
\hline & & LOWER & ARBUCKLE GROUP & 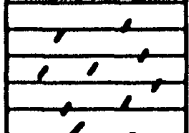 & \multirow[t]{3}{*}{ "ARBUCKLE " GROUP } \\
\hline & \multirow{2}{*}{ CAMBRIAN } & \multirow[t]{2}{*}{ UPPER } & BONNETERRE DOLOMITE & $2^{2}=$ & \\
\hline & & & REAGAN SANDSTONE & & \\
\hline$>570$ & \multicolumn{2}{|c|}{ PRECAMBRIAN } & PRECAMBRIAN & $\because \because \because \because \because$ & PRECAMBRIAN \\
\hline
\end{tabular}

FIGURE 2.6. - Time Stratigraphic Units-Cambrian and Ordovician Systems (from Cole, 1975). 


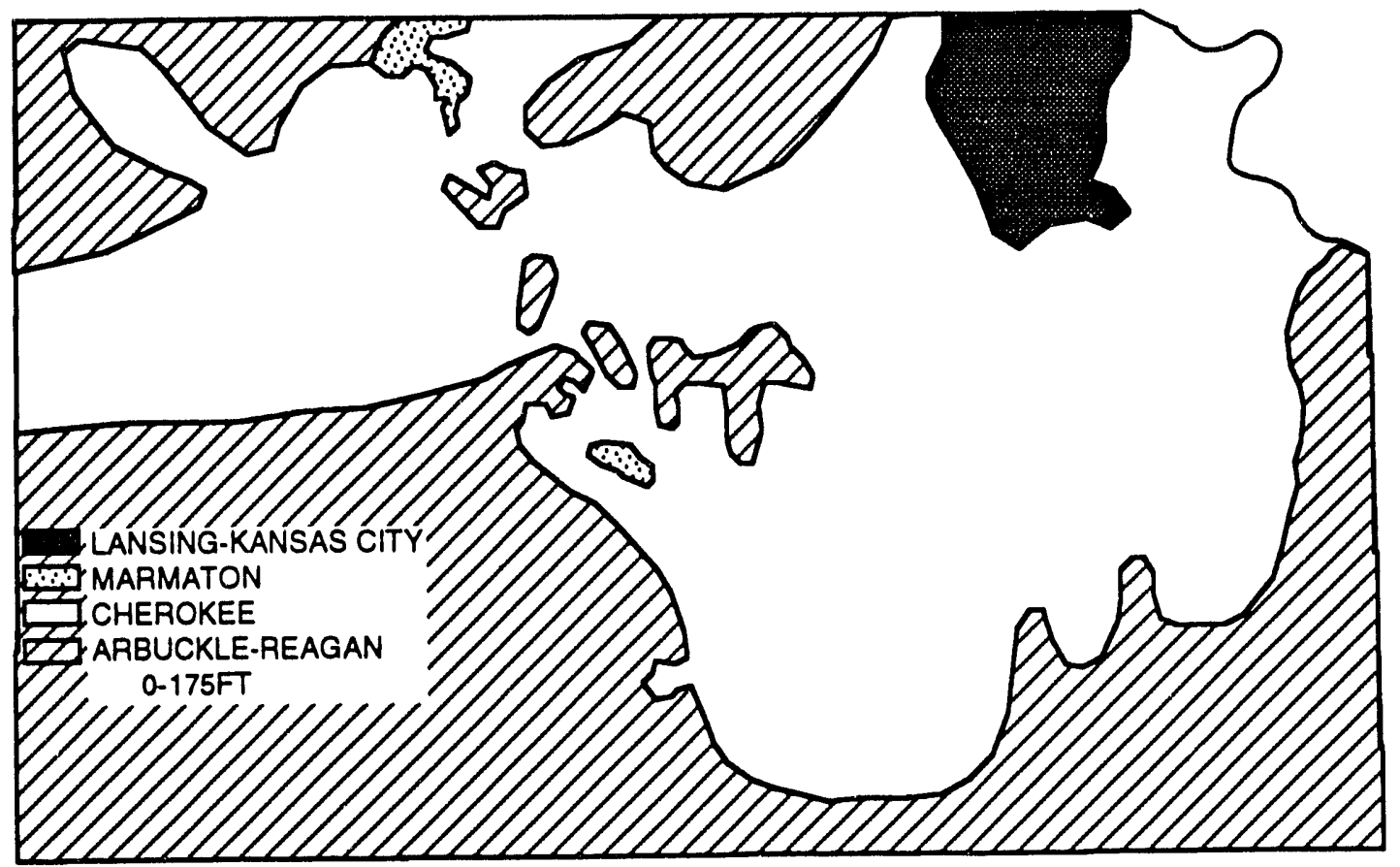

FIGURE 2.7. - Map Showing General Thickness of the Reagan Sandstone in Kansas. Map Base Shows Generalized Distribution of Rocks Which Rest on the Precambrian (from McElroy, 1965).

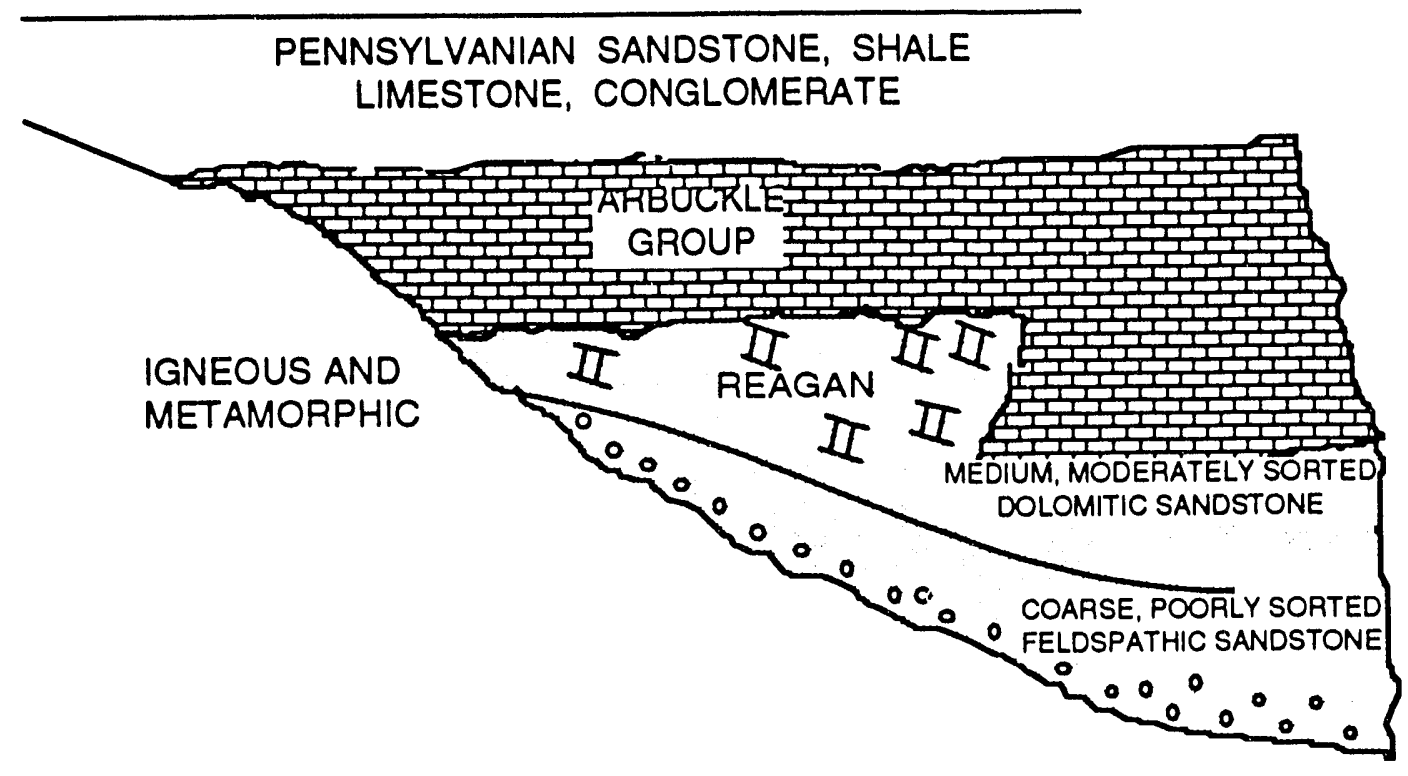

FIGURE 2.8. - Diagram Showing Proposed Lithologic and Overlap Relationships Between the Reagan Sandstone and the Arbuckle Group Over Precambrian "highs" in Central and Northwest Kansas (from McElroy, 1965). 


\section{$X$ WEST}

EAST $X^{\prime}$

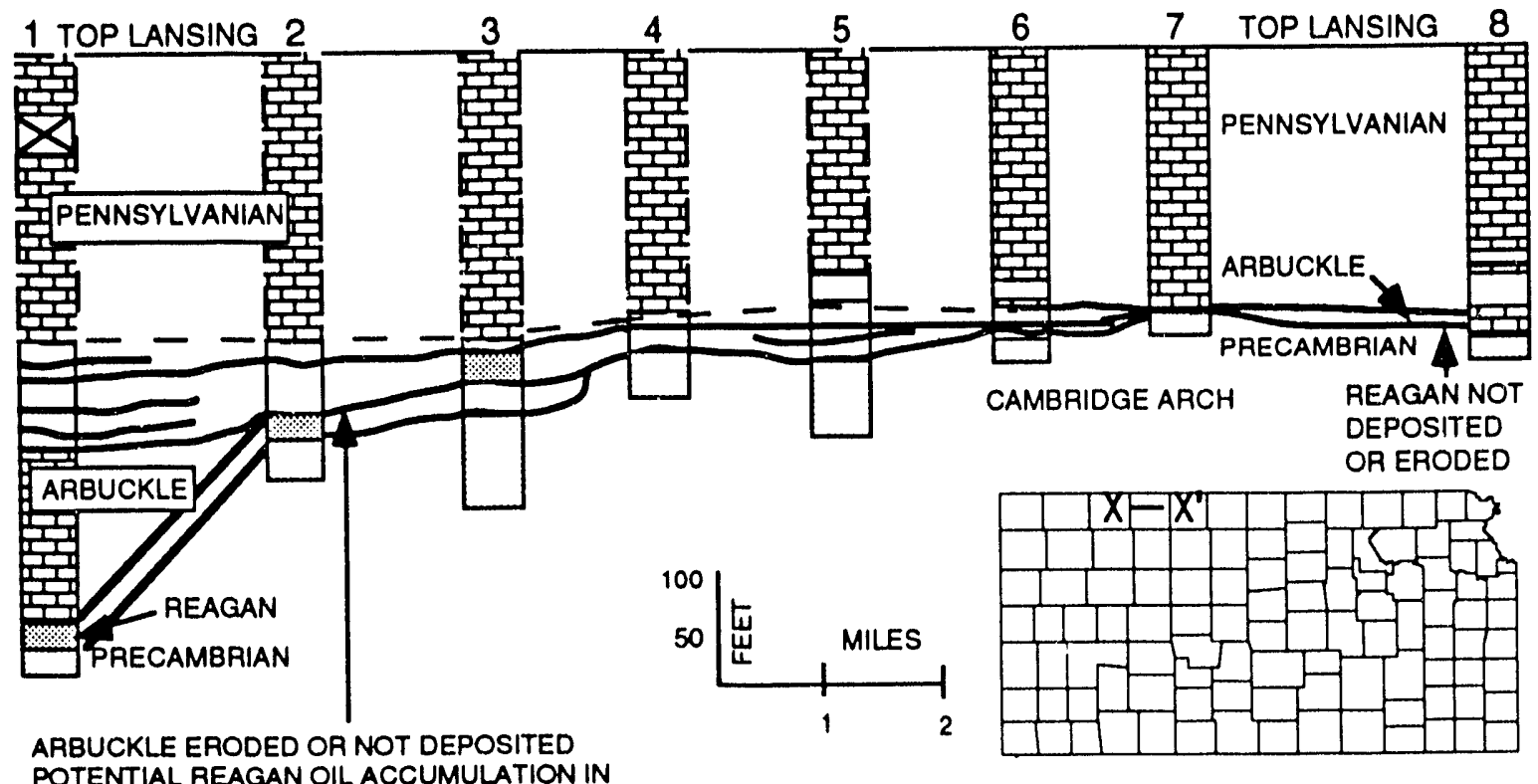

POTENTIAL REAGAN OIL ACCUMULATION IN

CONTACT WITH PENNSYLVANIAN SOURCE ROCK

FIGURE 2.9. - West-East Cross Section, Based on Logs of Kansas Sample Log Service, Across Cambridge Arch Showing Relation of Lower Pennsylvanian Rocks to Older Beds on Crest of Arch. Where Reagan is Absent, Arbuckle is in Direct Contract with Underlying Precambrian (from Merriam, 1983).

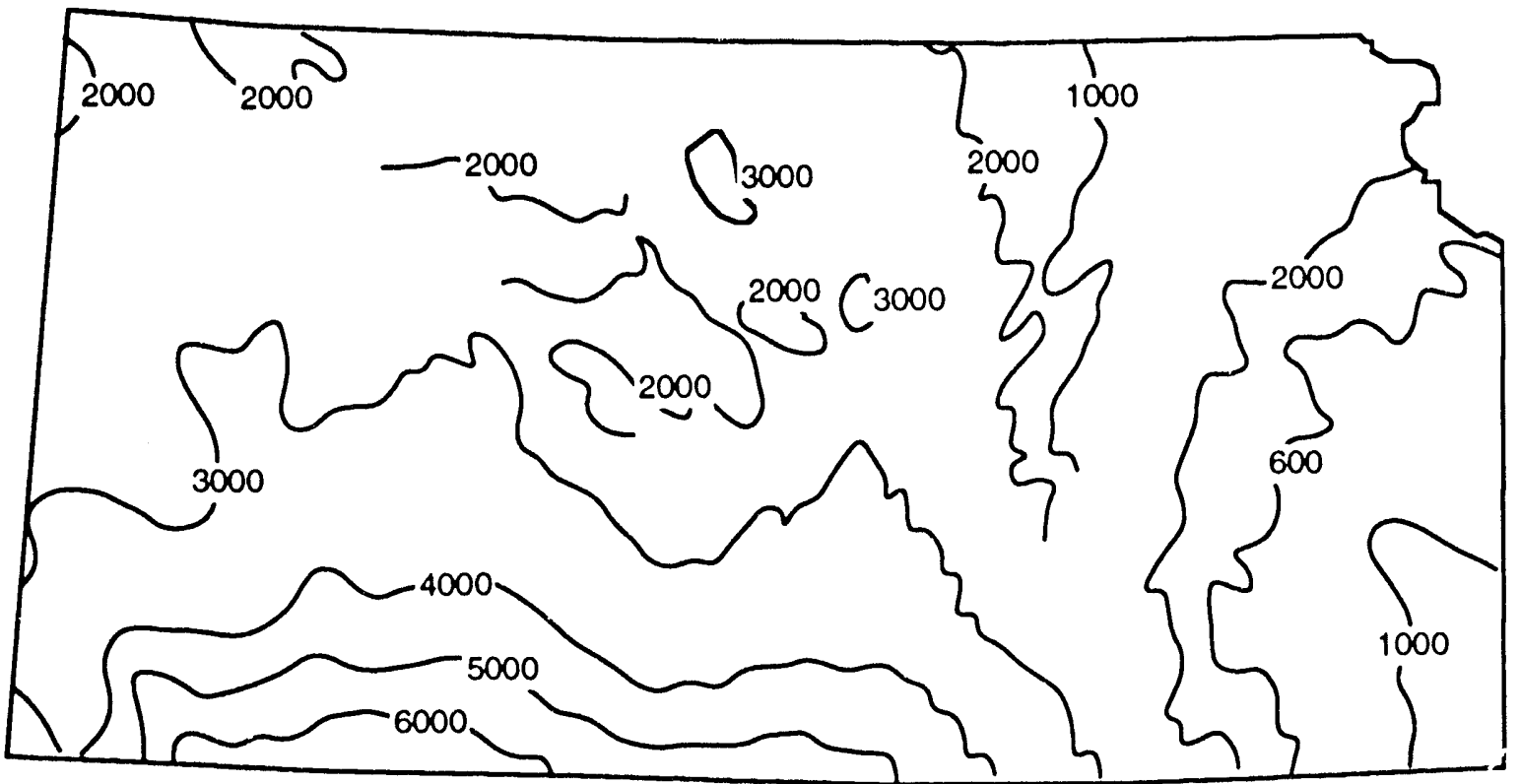

FIGURE 2.10. - Regional Configuration Map on Top of Precambrian Basement Complex in Kansas. This Map Shows Present Day Depth in Kansas (modified after Merriam, 1983). 


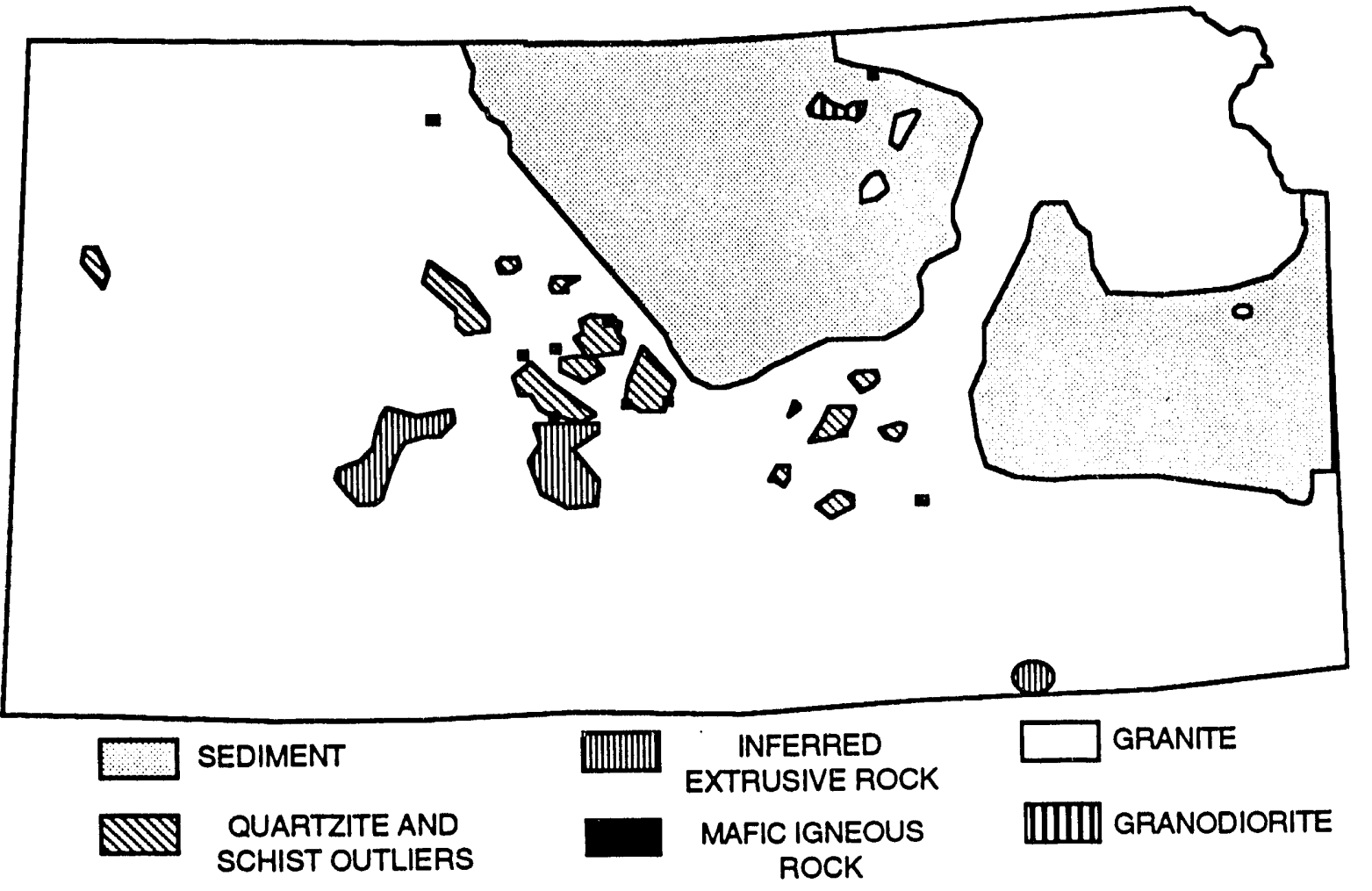

FIGURE 2.11. - Map of Kansas Showing Generalized Precambrian Basement Rock-Type Distribution Based on About 2,200 Wells (from Merriam, 1983).
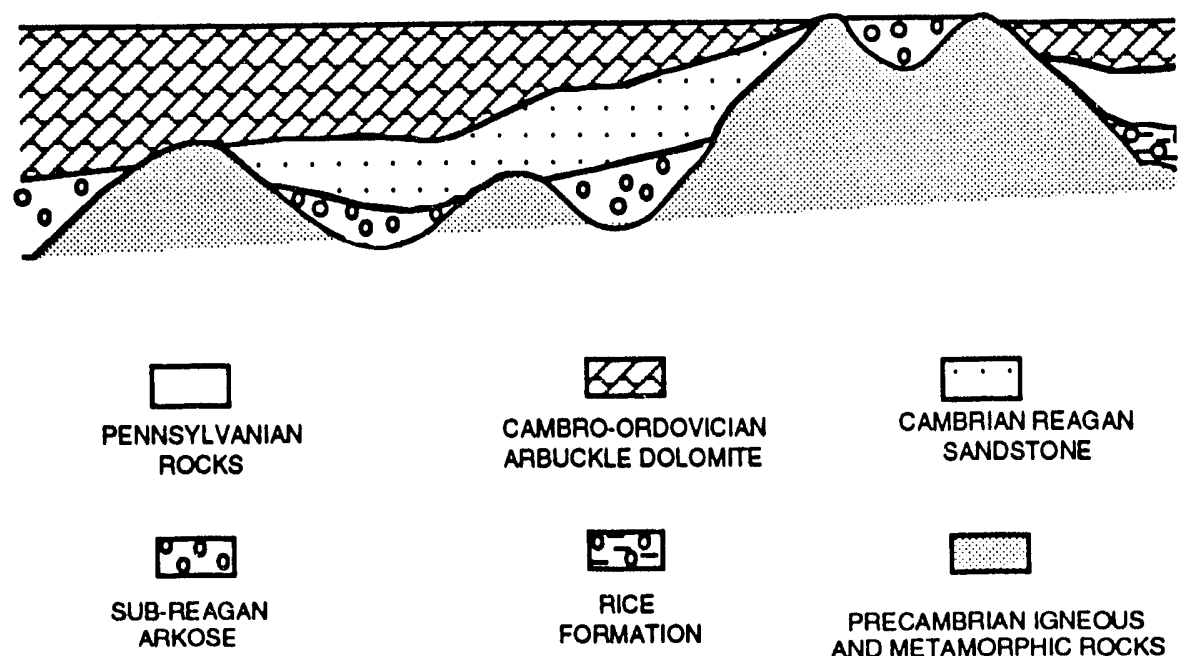

FIGURE 2.12. - Stratigraphic Diagram Showing Relationships Between Paleozoic Rocks and Precambrian Rocks in Northwestern Kansas (from McElroy, 1965). 
Oil accumulations in the Reagan sandstone are due, in part, to erosion or nondeposition of the overlying Arbuckle Group (Figs. 2.8 and 2.9). Fractured basement rock in contact with the Reagan formation sometimes produces oil because of migration downward into fractured rock that offers porosity for entrapment. Reagan sandstone deposition and oil occurrence are associated with buried Precambrian basement hills that offer structural highs for migration and oil accumulation. Source rocks for oil found in Reagan sandstone are overlying Pennsylvanian shales or nearby eroded Arbuckle dolomites on the flanks of structures or paleotopographic highs (Walters, 1953; Newell et al., 1987).

\section{CAMBRIAN-ORDOVICIAN PERIOD}

\section{Arbuckle Formation}

Arbuckle Formation carbonate sediments make up the entire section of sediments with their age crossing the Cambrian-Ordovician time boundary in Kansas and Oklahoma (Fig. 2.6). Most Arbuckle reservoirs are found over the Central Kansas uplift and its southward extension, the Pratt anticline (Fig. 2.1). Some Arbuckle carbonate reservoirs produce heavy oil in the southern Cherokee and Sedgwick Basins of southeastern Kansas. The annual oil and gas production reports compiled and published by the Kansas Geological Survey list 27 oil fields that produce heavy oil from the Arbuckle Formation.

The Arbuckle Group, composed mostly of light gray to white vuggy, cherty dolomite, has been subdivided and correlated with equivalent surface outcrop exposures in adjacent states by studying insoluble residues (Newell et al., 1987). This group includes rocks comprised of dolomite, sandy or cherty dolomite and sandstone, which may have excellent porosity and permeability. Oldest Arbuckle Group rocks, basal Arbuckle, in the subsurface are quartz sandstone, sandy carbonates, or feldspathic, "granite wash" sandstone. Dolomite above the basal sandstone may be sandy, gray to white or buff to light-brown in color having textural variations from coarse to fine. Upper Arbuckle Group dolomite (Ordovician age) is generally sandier, containing more chert distinguishing it from younger dolomite beds by the presence of oolites or concentrically banded chert. These rocks have little or no shale except at the top, directly underlying the Simpson Group (Cole, 1975).

Pre-Simpson uplift and erosion account for thin to absent Arbuckle carbonates locally and on some basement structural highs, the Nemaha uplift, Cambridge arch, and Central Kansas uplift in Kansas counties of Marshall, Pottawatomie, Riley, western Nemaha, eastern Washington, Chase, Butler, Norton, and Decatur (Figs. 2.1, 2.8, 2.9, 2.13 and 2.14) (Newell, 1987; Jewett, 1951, 1954; Merriam, 1963). In some areas Arbuckle dolomite may be quite thick locally, but generally thickens southward to a thickness in excess of 1,000 feet (Fig. 2.15)-along the KansasOklahoma state line (Cole, 1975). 


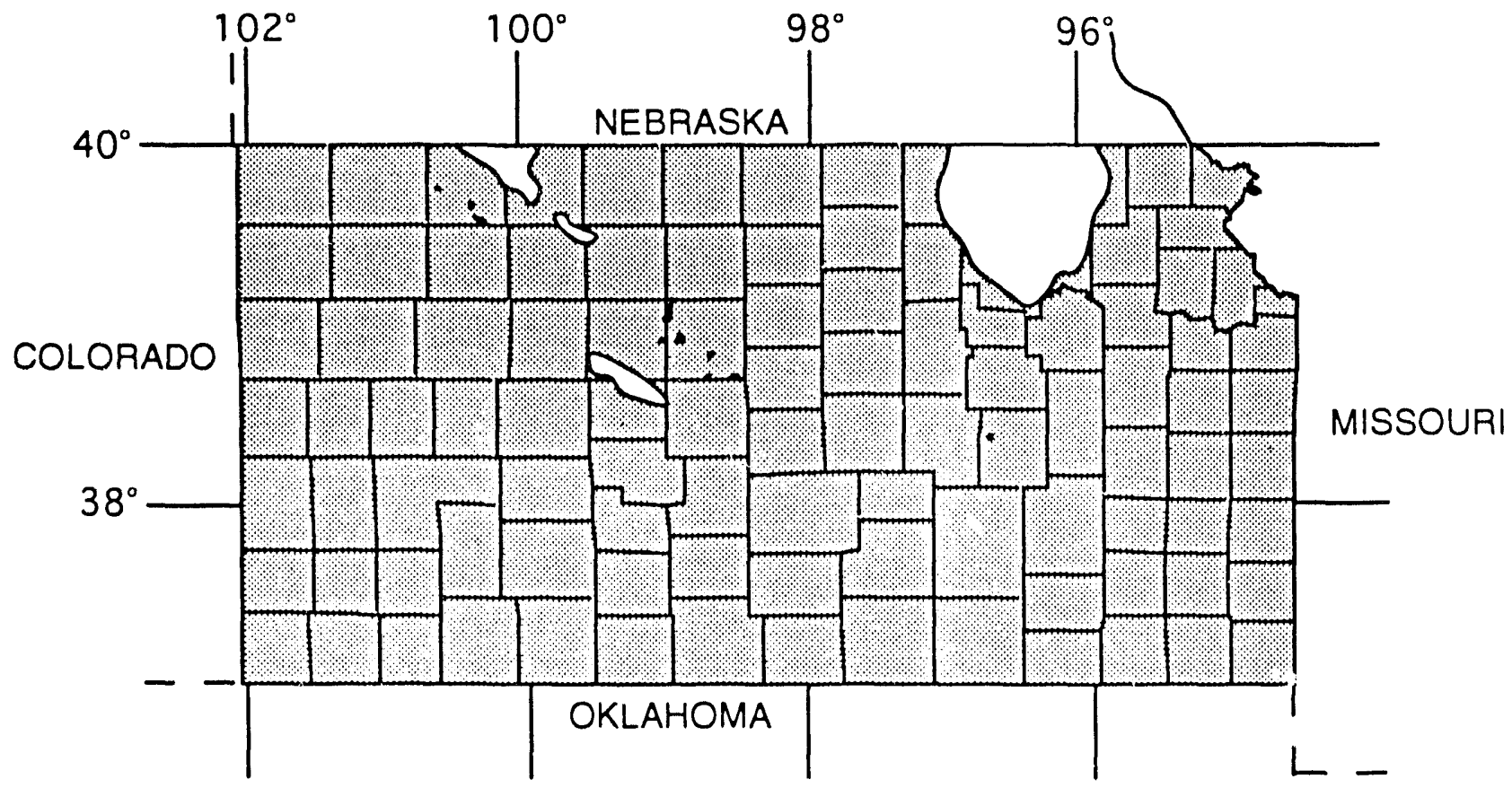

FIGURE 2.13. - Map of Kansas Showing Subsurface Distribution of Arbuckle Group (CambrianOrdovician) (from Merriam, 1983).

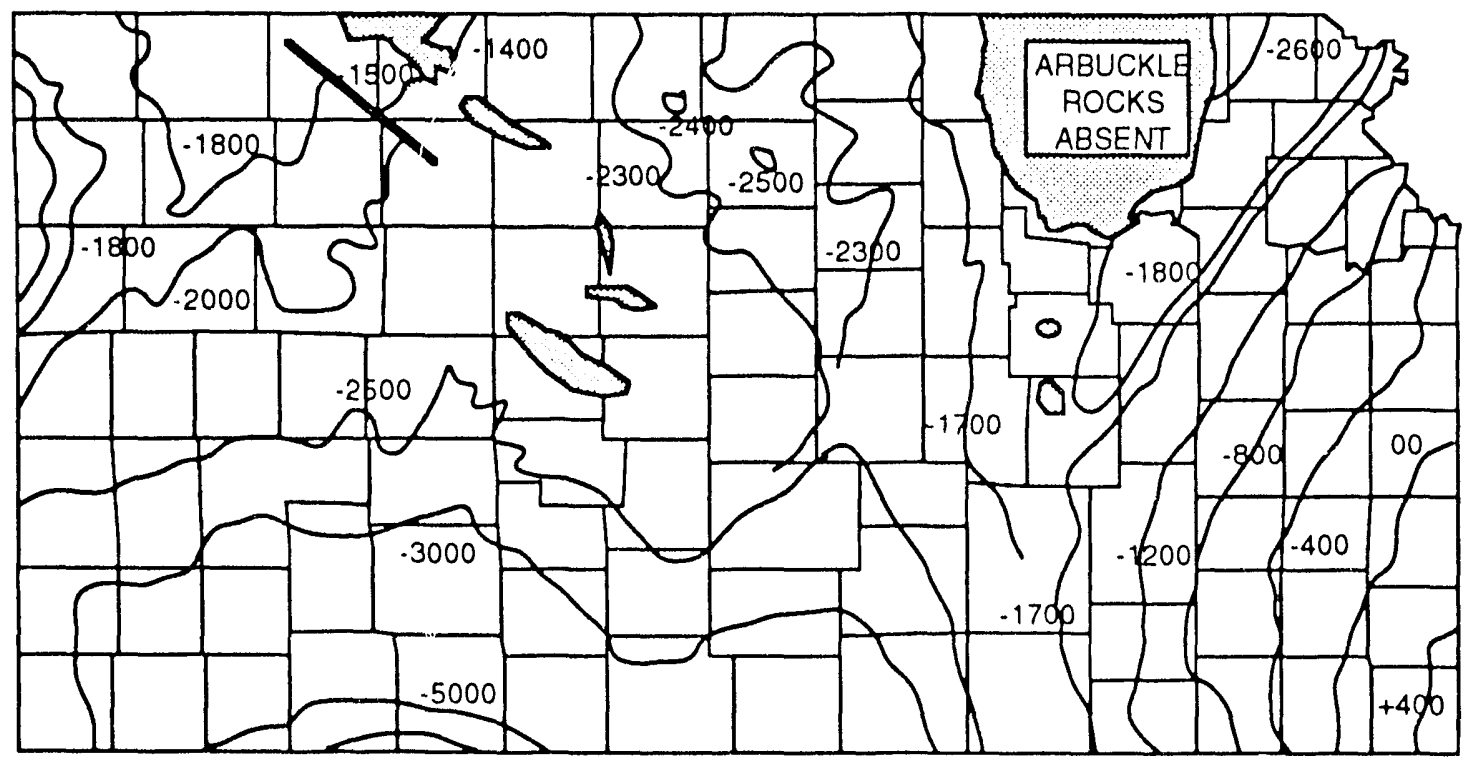

FIGURE 2.14. - Preliminary Regional Structural Map Contoured on Top of Arbuckle Rocks (Cambrian-Ordovician) in Kansas. Contour interval is in feet (from Merriam, 1983). 


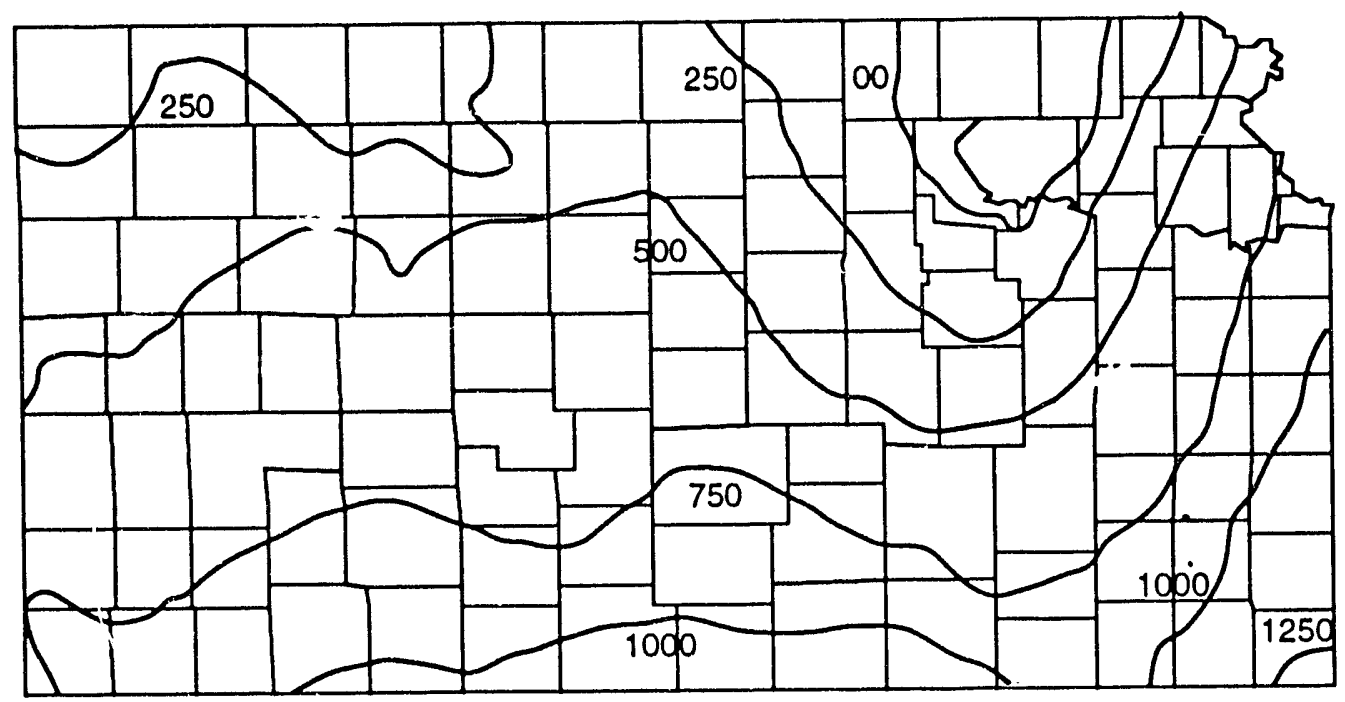

FIGURE 2.15. - Isopach Map, Arbuckle Formation, contour interval is in feet (from Cole, 1975).

\section{MIDDLE ORDOVICIAN PERIOD}

\section{Simpson Formation}

The Simpson Formation is the lowest Middle Ordovician heavy oil producing reservoir (Fig. 2.6). Annual oil and gas production reports compiled and published by the Kansas Geological Survey list two oil fields that produce heavy oil from the Simpson Formation.

Simpson production is primarily limited to south-central Kansas. Producing trends from Simpson rocks may be found along the Pratt anticline, throughout the Sedgwick and Forest City Basins, flanks of the Chautauqua arch, and along the periphery of the Central Kansas uplift (Figs. $2.1,2.16,2.17$, anc 2.18 ). Some oil reservoirs where Simpson production may be found beneath the pre-Pennsylvanian unconformity are in Butler, Coffey, and Sumner counties in southeastern Kansas (Fig. 2.19) (Jewett, 1954; Newell et al., 1987).

The basal unit of the long term North American continental Tippecanoe transgression is known as the Simpson Group in the Midcontinent. This group of sediments was probably deposited over most of the state, but erosion throughout various parts of the state resulted in removal. Tectonic movement in Late Mississippian-Early Pennsylvanian Periods accounts for the removal of this group over much of the Central Kansas uplift, the Nemaha uplift, and Northwestern Kansas. The Simpson is not present in southeastern Kansas southeast of a line from Cowley County to Miami County (Fig. 2.17) (Merriam, 1983). The broad northwest-southeasttrending pre-Devonian (pre-Chatanooga) Chautauqua Arch caused the absence of the Simpson group in this area (Figs. 2.16 and 2.18). 


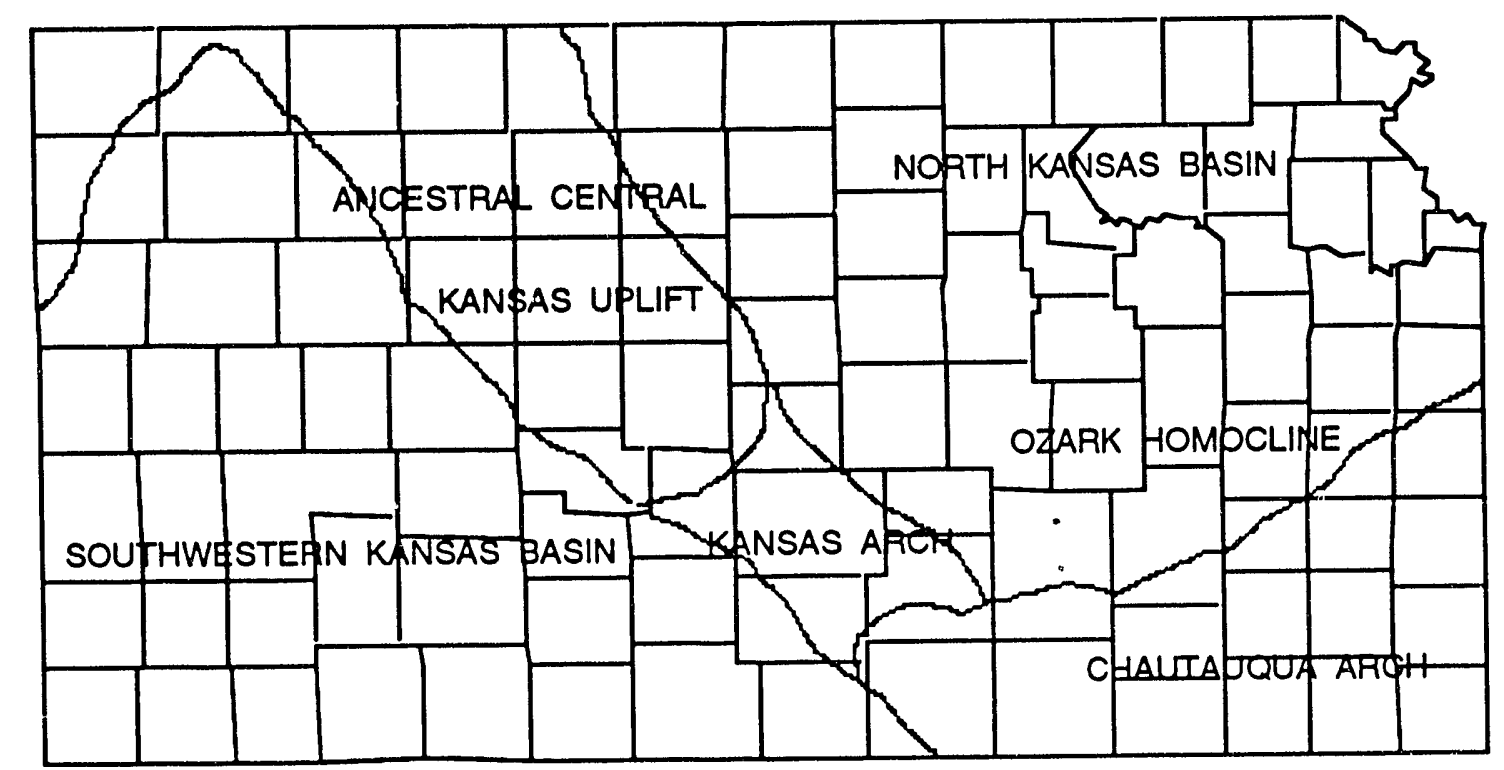

FIGURE 2.16. - Pre-Mississippian-Post-Devonian Structural Features in Kansas (from Merriam, 1983).

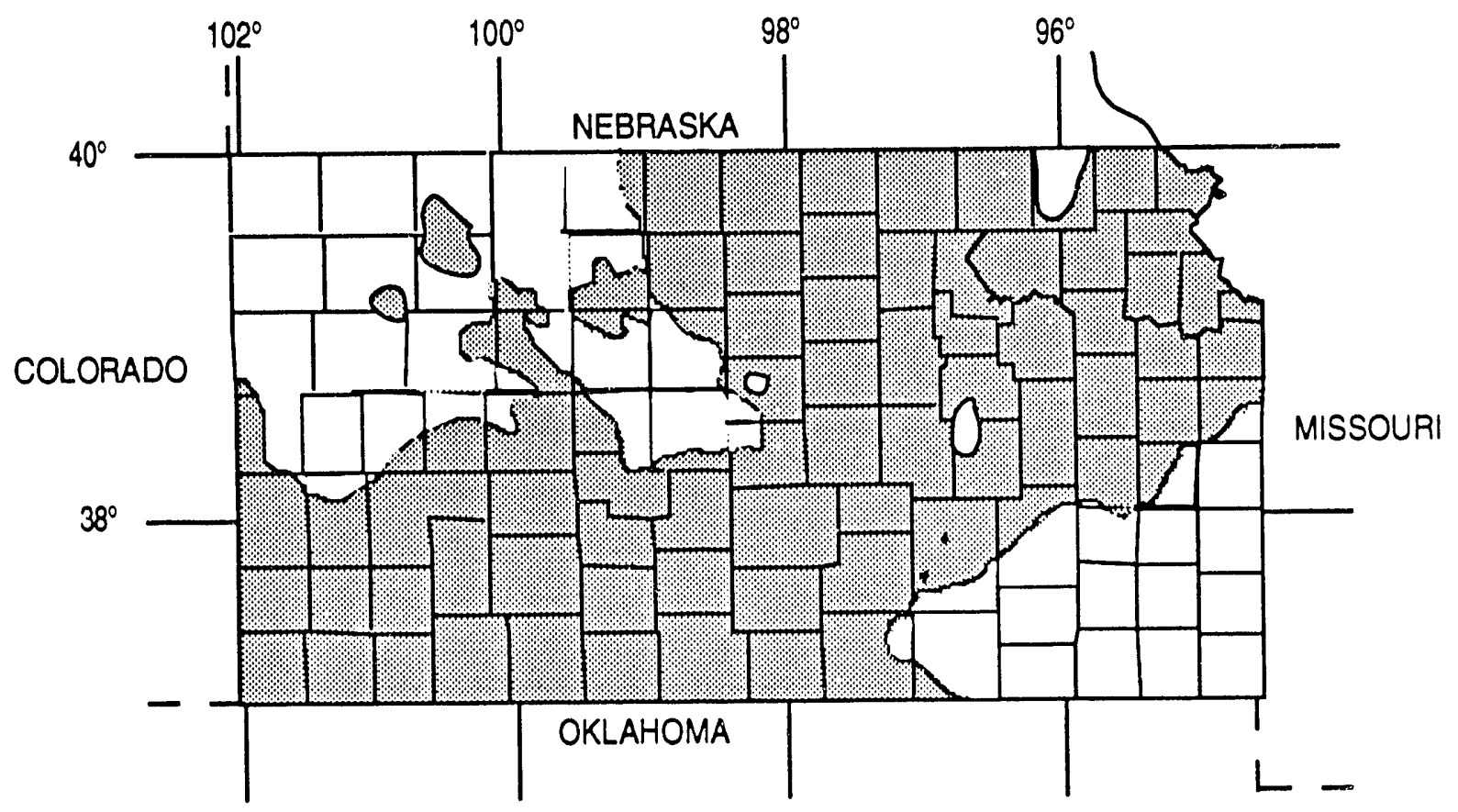

FIGURE 2.17. - Map of Kansas Showing Subsurface Distribution of Simpson Group (Middle Ordovician) (from Merriam, 1983). 


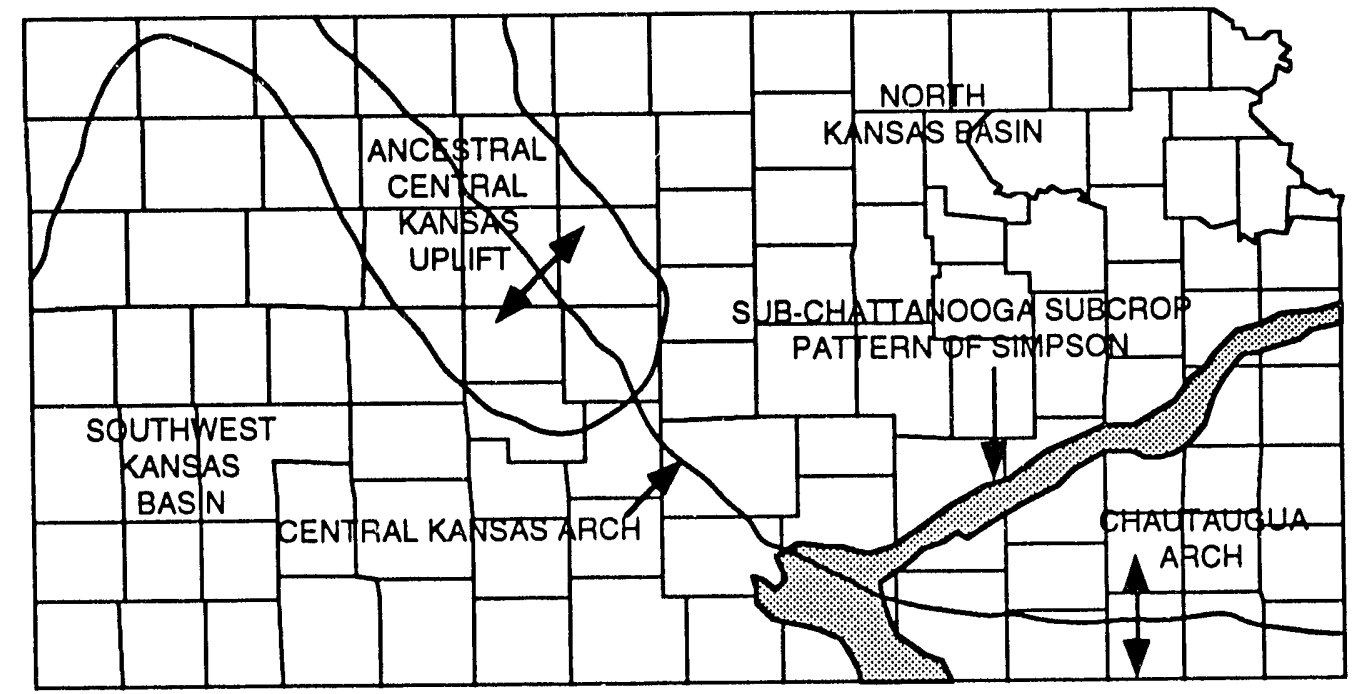

FIGURE 2.18 - Pre-Mississippian-Post-Ordovician Structural Features of Kansas. Subcrop Pattern of Simpson Below the Chattanooga Shale (from Newell et al., 1987).

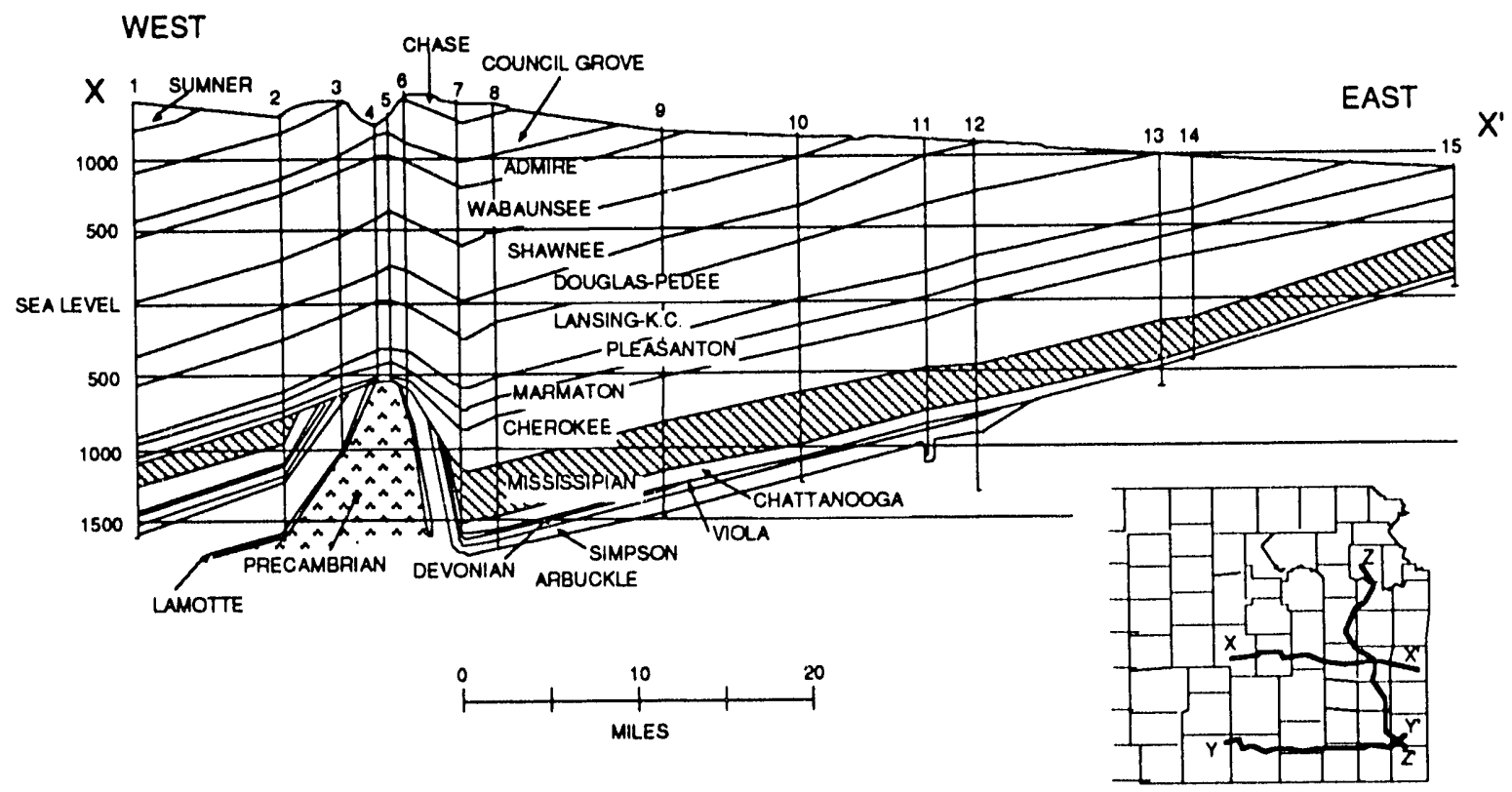

FIGURE 2.19. - Pre-Pennsylvanian Sediments in Contact With Pennsylvanian in an Eastern Kansas Structural Cross Section Structure (from Merriam, 1963). 
Off the flanks of the Chautauqua arch the Simpson Group is thickest. It reaches a thickness of $150 \mathrm{ft}(45 \mathrm{~m})$ in northeastern Kansas along the western flank of the Forest City basin and eastern flank of the Salina basin. Maximum thickness in southern Kansas is $250 \mathrm{ft}(75 \mathrm{~m})$ in Harper County near the Kansas-Oklahoma state line (Fig. 2.20) (Cole, 1975). It thickens southward into Oklahoma where it is divided into several stratigraphic units (Ireland, 1965). Local thicknesses in eastern Kansas in excess of $400 \mathrm{ft}(125 \mathrm{~m})$ are attributed to sinkholes that developed in the underlying Arbuckle Group carbonate rocks (Newell et al., 1987).

In Kansas, the Simpson Group is a sand-shale sequence with minor carbonate beds. Lightgray, quartz-rich sheet sandstones sometimes called the St. Peter or Wilcox sandstone are the main reservoir rocks of the Simpson (Fig. 2.6) (Goebel, 1968). There may be more than one producing sandstone reservoir present when oil accumulation is found. In the Forest City Basin, Simpson shales are credited as the source beds for oil (Newell et al., 1985).

There are three geologic settings for oil accumulations in the Simpson: (1) the Simpscn is truncated by the sub-Pennsylvanian unconformity forming structural-stratigraphic and stratigraphic traps, occurring along the periphery of the Central Kansas Uplift and along the crest of the Nemaha Uplift and Pratt anticline, (2) the Simpson is truncated by the pre-Chattanooga unconformity forming structural-stratigraphic and stratigraphic traps, occurring in southeastern Kansas along the subcrop trend on the northern flank of the Chautauqua Arch, and (3) structural traps where the Simpson is found in a normal sequence below the Viola Formation and above the Arbuckle Group, occur in the Forest City, Sedgwick, and southern Salina basins (Figs. 2.1, 2.16, and 2.18) (Newell et al., 1987).

\section{Viola Formation}

The Viola Formation is the uppermost Middle Ordovician age reservoir rock to be discussed in this section (Figs. 2.6 and 2.21). There are 4 reservoirs identified in the annual oil and gas production reports compiled and published by the Kansas Geological Survey that produce heavy oil in Kansas.

Viola production is distributed through south-central and northeast Kansas approximately the same as the underlying Simpson Group. Oil and gas are produced on the Pratt anticline, but oil production is dominant in other areas. Viola and the younger "Hunton" carbonates are the main producing formations in the Forest City Basin (Fig. 2.1). 


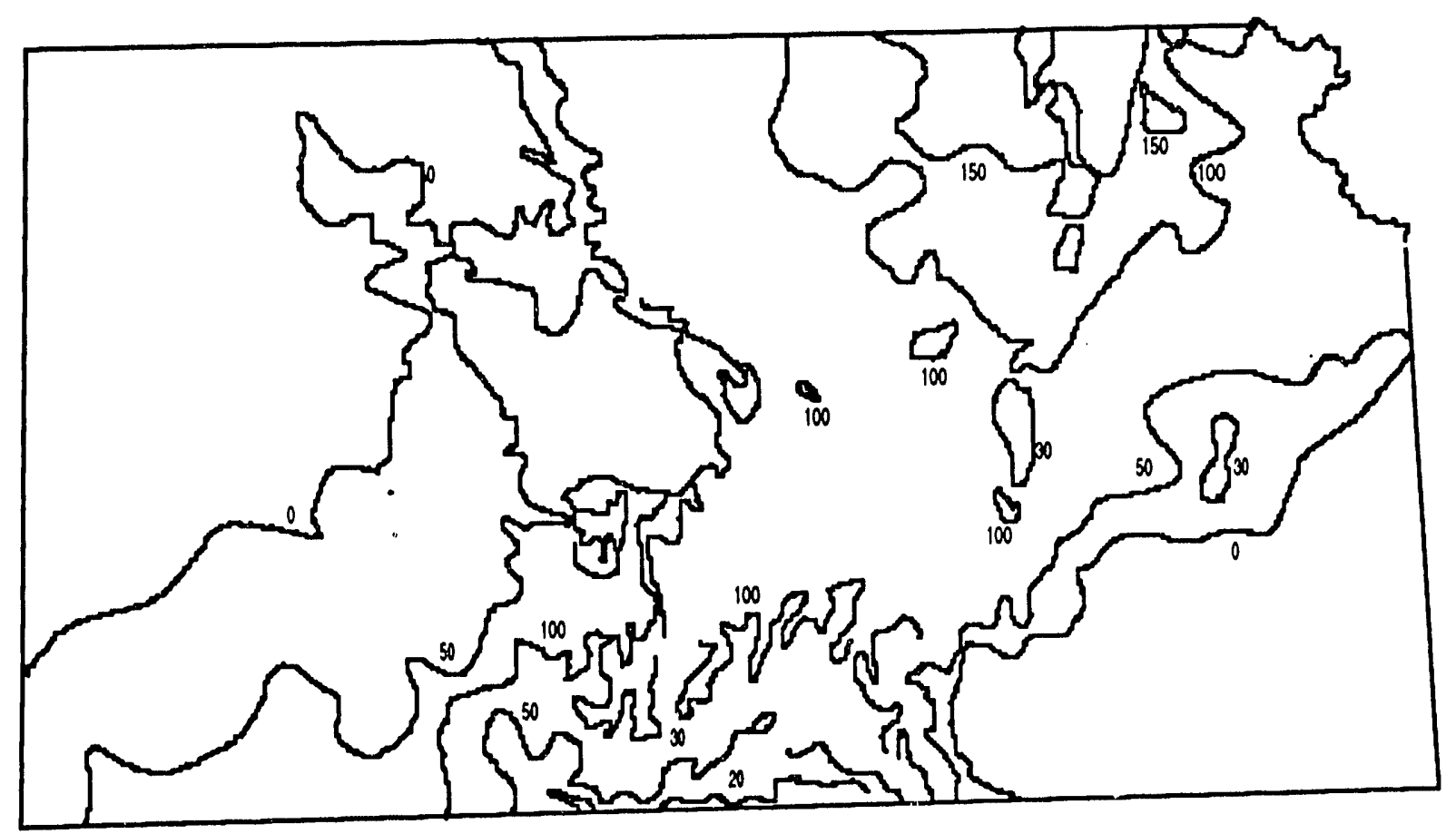

FIGURE 2.20. - Isopach Map of the Simpson Group (from Cole 1975). Contour is in feet.

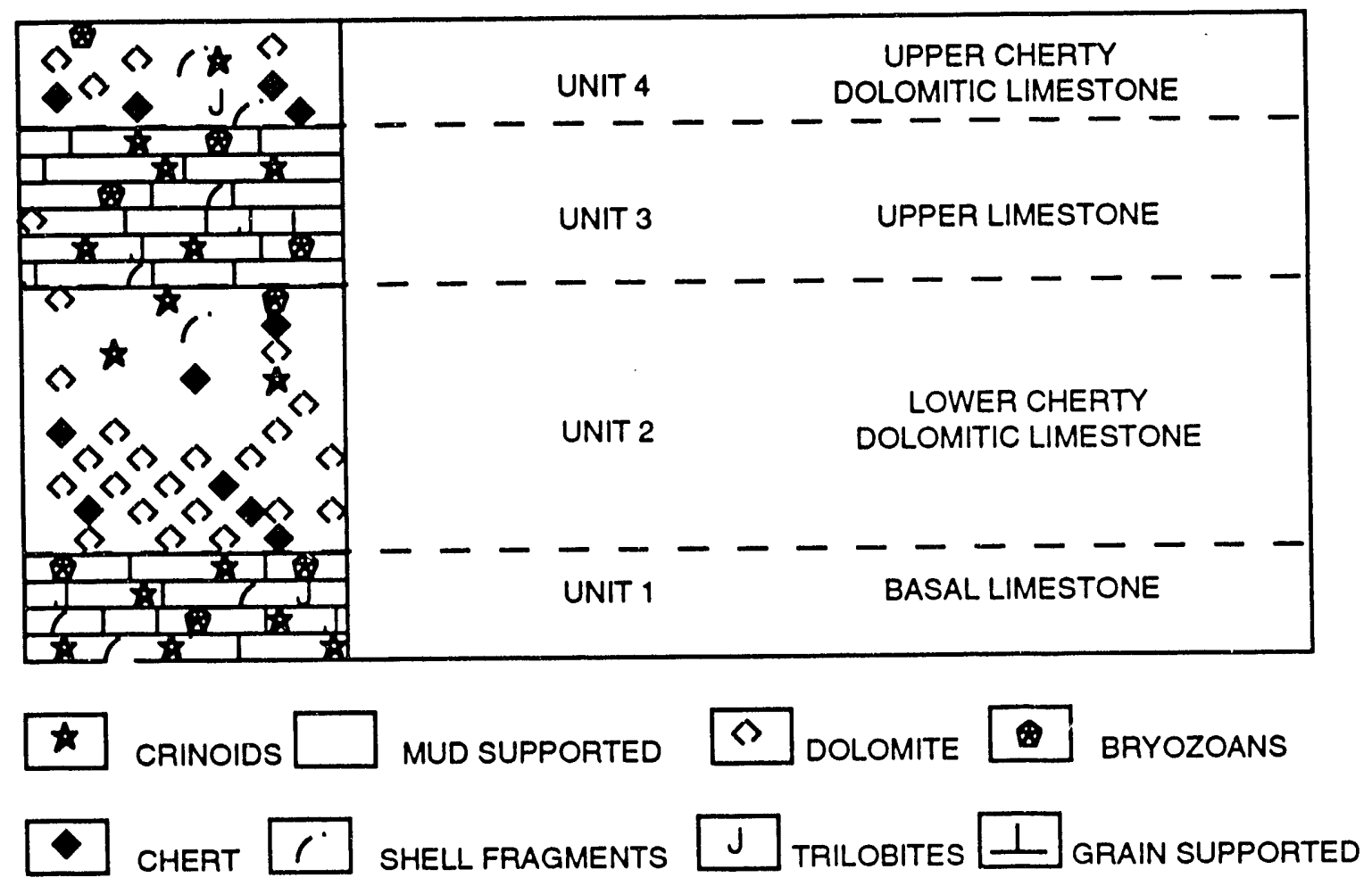

FIGURE 2.21. - Generalized Stratigraphic Section of the Viola Limestone in South-Central Kansas (from St. Clair, 1982). 
Pre-Pennsylvanian erosion in northwest Kansas, the northern part of the Nemaha uplift and the Central Kansas uplift removed the Viola Limestone in these areas (figure 2.22). PreChattanooga erosion on the Chautauqua arch in southeastern Kansas also accounts for the absence of Viola Limestone (Merriam, 1963). The Viola exceeds $300 \mathrm{ft}$ in Jewell and Republic counties, where it is thickest (Figs. 2.16, 2.19, and 2.23, Cole, 1975). It is fine- to coarse-grained limestone and dolomite with variable quantities of chert. This formation is characterized by dolomitic limestone in south-central Kansas. In the Forest City and eastern Salina basins it is nearly all dolomite (Goebel, 1968, Cole, 1975). Intergranular, vuggy, moldic, and fracture porosity are common in the Viola (Caldwell and Boeken, 1985; St. Clair, 1985). Taylor (1947), Ver Wiebe (1948), and St. Clair (1985) have divided the Viola into informal subdivisions in Kansas (Newell et al., 1987).

The most significant oil production from Viola carbonates in the Midcontinent occur in Kansas. Elsewhere in the Midcontinent, it is not a major oil producing formation. Oil production from the Viola is found in structural and stratigraphic traps in Kansas (Newell et al., 1987).

\section{SILURIAN AND DEVONIAN PERIODS}

Rocks of Silurian and Devonian age are not significant formations for oil production in Kansas (Fig. 2.24). These rocks are commonly identified by drillers as "Hunton" in Kansas. These rock that are identified as "Hunton" in Kansas are a misnomer because the name has been applied to a group of limestones and dolomites sandwiched between overlying Chattanooga Shale and underlying Maquoketa shale. The true Hunton Formation in the Midcontinent is a unit of lower Devonian limestones deposited in the Ardmore and Anadarko basins in southern Oklahoma. Rocks that are equivalent to these are missing in Kansas (Newell et al., 1987). One heavy oil producing reservoir is listed in the annual oil and gas proc'uction reports compiled and published by the Kansas Geological Survey. This may be accurate since these sediments are not major oil producers in Kansas.

The zone between the Silurian and Middle Devonian that is missing in Kansas can be recognized in a few localities by a zone that carries varying low percentages of sand grains. In areas where this sand is not present, the unconformity is difficult to recognize (Merriam, 1963). Hunton rocks in Kansas have been zoned by insoluble residues and microfossils. Where these rocks can be differentiated by lithology, those of Devonian age are generally gray to brown, finegrained, crystalline dolomite or limestone with minor chert. Silurian age rocks are cherty, but coarser-grained and slightly sandy dolomite with vuggy porosity (Merriam, 1963; Newell et al., 1987). 


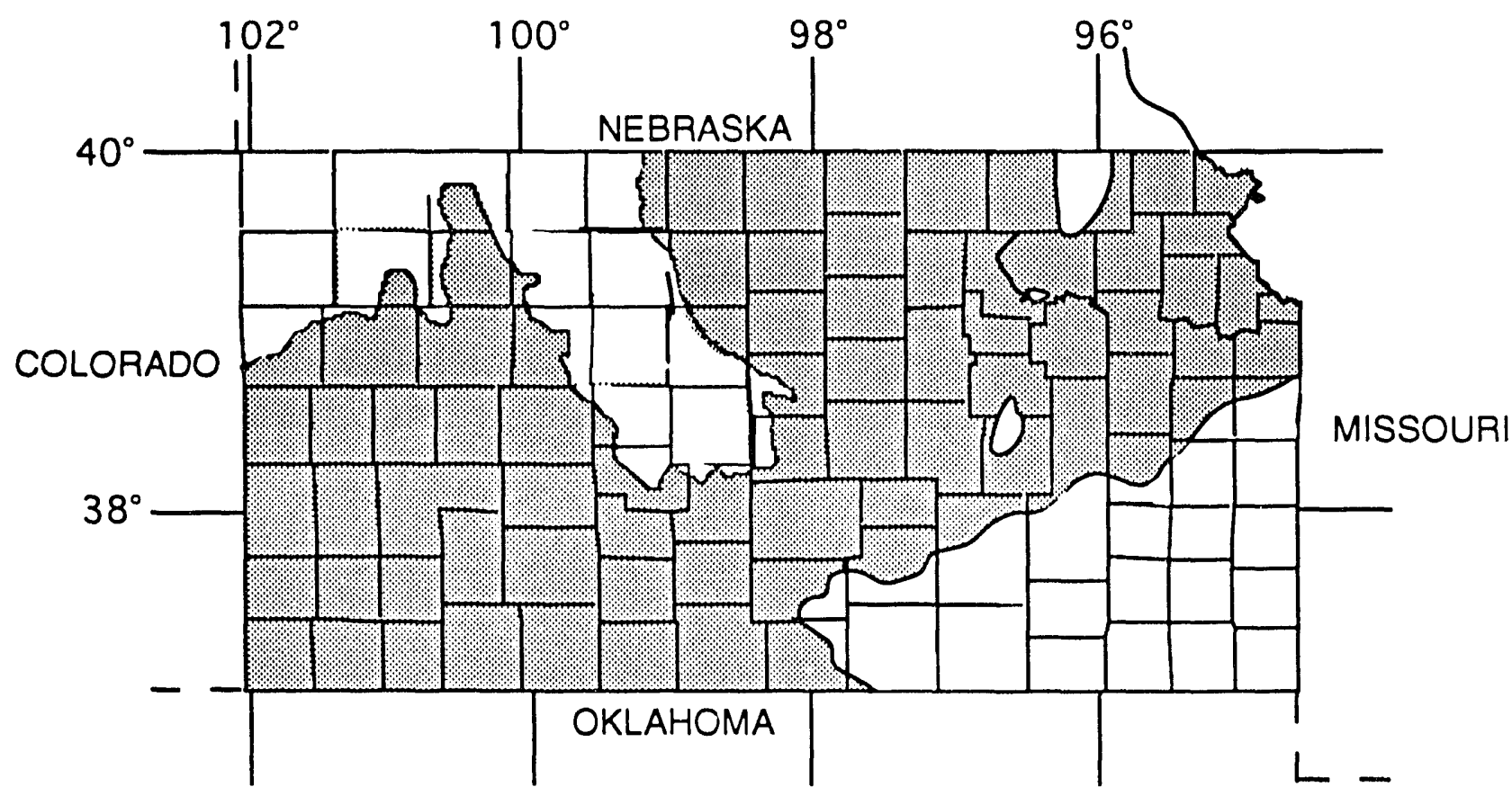

FIGURE 2.22. - Map of Kansas Showing Subsurface Distribution of Viola Limestone (Middle Ordovician) (from Merriam, 1983).

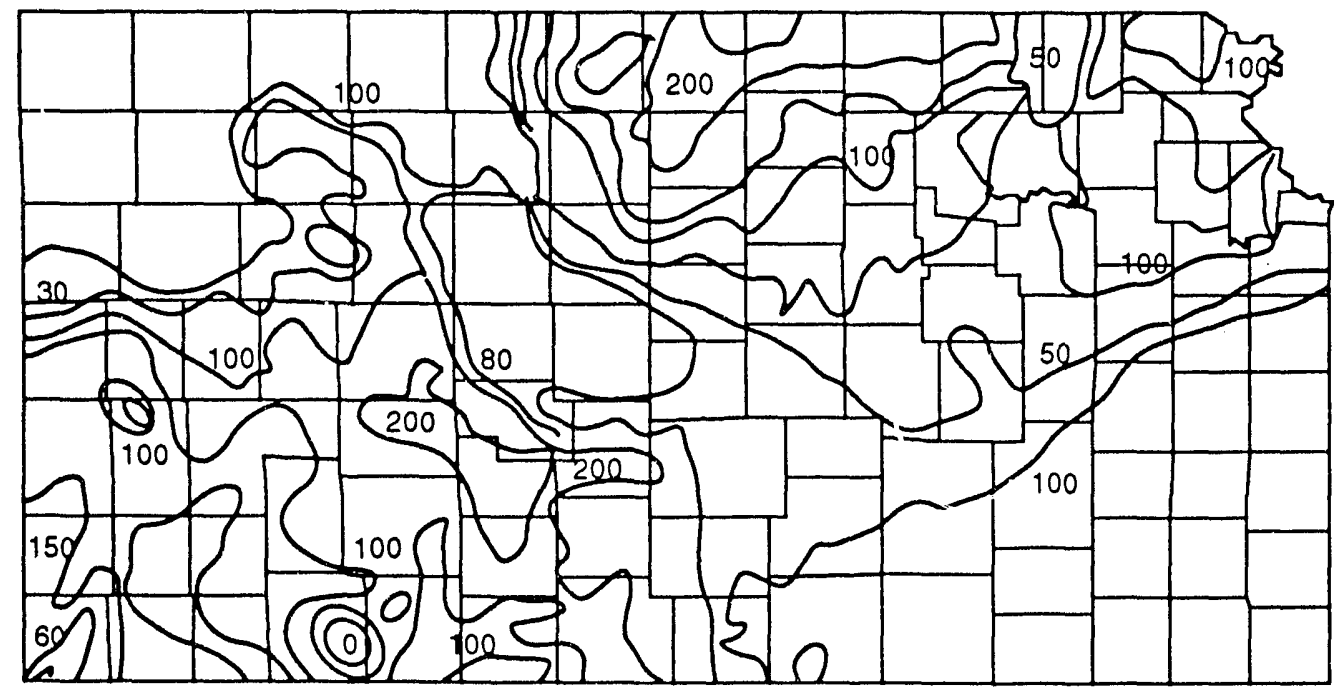

FIGURE 2.23. - Isopach map of Viola Formation (from Cole, 1975). Contour is in feet. 


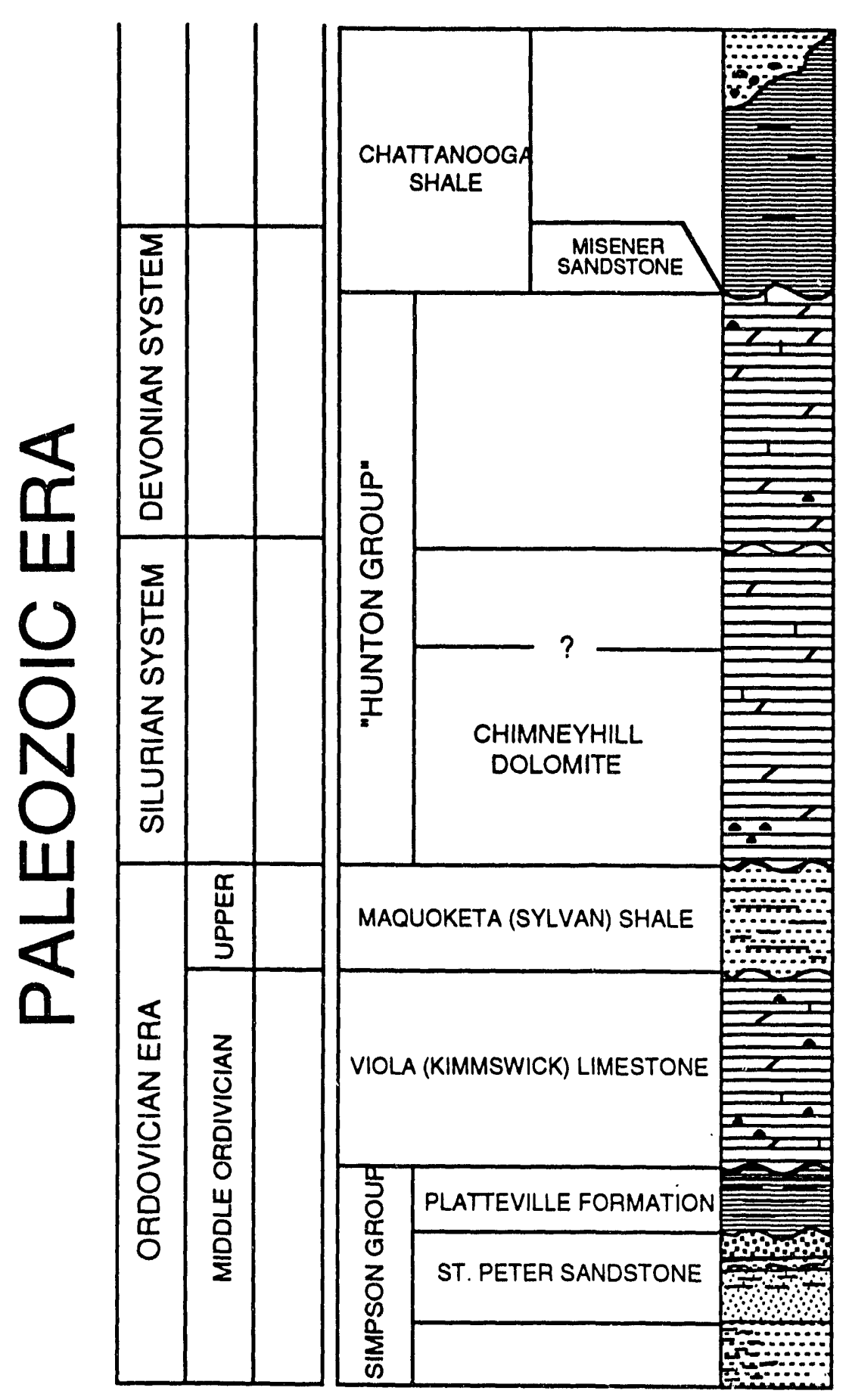

FIGURE 2.24. - Stratigraphic Column of the Ordovician, Silurian, and Devonian Systems in Kansas (from St. Clair, 1982). 
Kansas producing trends for Silurian and Devonian rocks cover a broad east-west trend through six counties in east-central Kansas (Marion, McPherson, Harvey, Reno, Butler, and Sedgwick counties) in the northern part of the Sedgwick basin (Figs. 2.1 and 2.25). There is a north-northeasterly producing trend in Morrison County extending to the Kansas-Nebraska state line, in the Forest City basin and on the adjacent Nemaha uplift. Silurian and Devonian rocks are mostly limited to these areas of Kansas. Maximum thickness is in eastern Nemaha County where it reaches approximately $650 \mathrm{ft}$ (Fig: 2.26) (Jewett and Merriam, 1959; Newell et al., 1987).

\section{MISSISSIPPIAN PERIOD}

Seven heavy oil reservoirs in fields that produce from Mississippian age rocks were identified. None of these reservoirs are major and qualify as between $10^{\circ}$ and $20^{\circ} \mathrm{API}$ gravity. Because of the large number of Mississippian oil fields in the state and the lack of oil gravity data for all reservoirs in the annual oil and gas production reports by the Kansas Geological Survey, there may be more heavy reservoirs in Kansas than those identified for this study.

Thickness of Mississippian rocks is largely dependent upon structural movement during late Mississippian-early Pennsylvanian time (Figs. 2.27 through 2.30)). These rocks are thin to absent across structurally uplifted areas and local anticlines. They are thickest in synclines and basins (Newell et al., 1987).

Kinderhookian, Osagian, and Meramecian rocks are older Mississippian rocks in Kansas. They consist of sandstones with minor limestones, cherts, and cherty limestones that underlie younger Mississippian rocks that are Chesteran age (Figs. 2.31 and 2.32). These older sediments have been removed from the Central Kansas uplift and parts of the Nemaha uplift by late Mississippian-early Pennsylvanian erosion, but are present over most of the rest of Kansas. PreChesteran-age Mississippian rocks in Kansas reach a thickness of approximately $1,4())$ ft in the Hugoton basin where this section is preserved (Goebel, 1968; Newell et al., 1987).

Chesteran age Mississippian rocks are younger than those described above. They consist of marine and nonmarine shales and sandstones with minor limestones, cherts and cherty limestones. These rocks reach their maximum thickness of $5(x) \mathrm{ft}$ along the Kansas-Oklahoma state line in the Anadarko Basin. This thickness occurs in southwestern Kansas in Stanton, Grant, Haskell, Morton, Seward, and Meade Counties (Goebel, 1968).

Mississippian oil production dominates along the flanks of the Nemaha uplift and western side of the Cherokee basin. Gas and associated oil production are present in the Sedgwick and Hugoton basins and on the Pratt anticline (Fig. 2.1). Significant gas is associated with oil production on the flank of the Hugoton basin southwest of the Central Kansas uplift (Newell et al., 1987). Most Mississippian production in the Midcontinent occurs at or near the top of the 


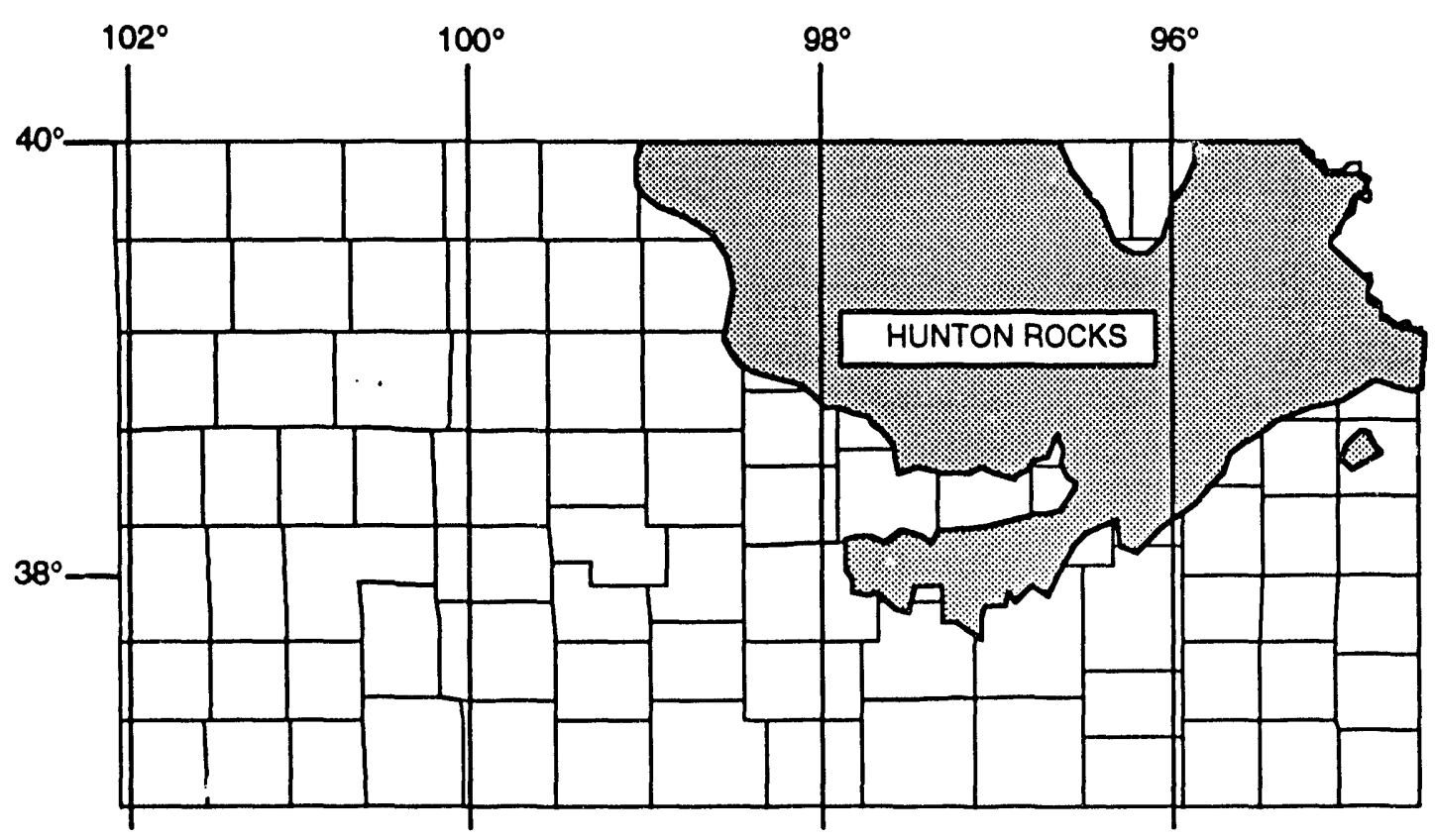

FIGURE 2.25. - Map of Kansas Showing Subsurface Distribution of "Hunton" Rocks (from Merriam, 1983).

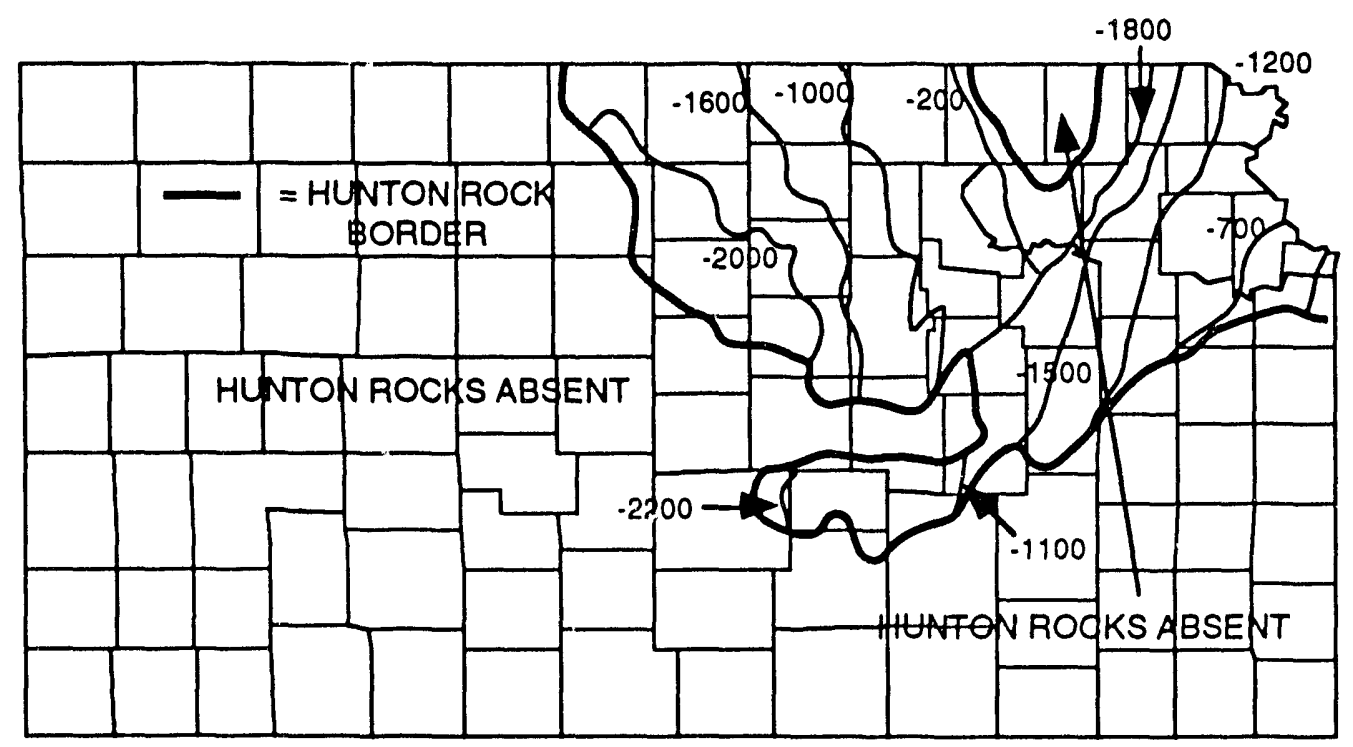

FIGURE 2.26. - Preliminary Regional Structural Map Contoured on Top of "Hunton" Rocks (Silurian-Devonian) in Kansas. Contours are in feet (from Merriam, 1983). 


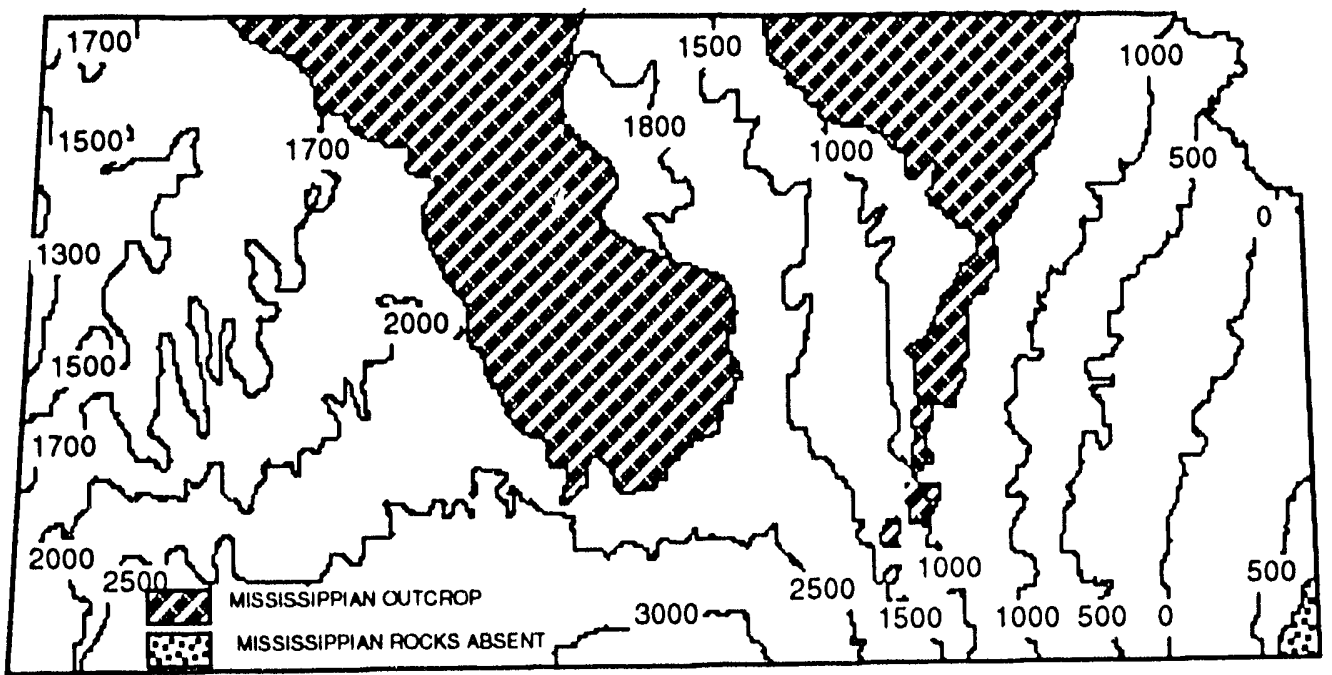

FIGURE 2.27. - Preliminary Regional Structural Map Contoured on top of Mississippian Rocks in Kansas (from Merriam, 1983). Contours are in feet.

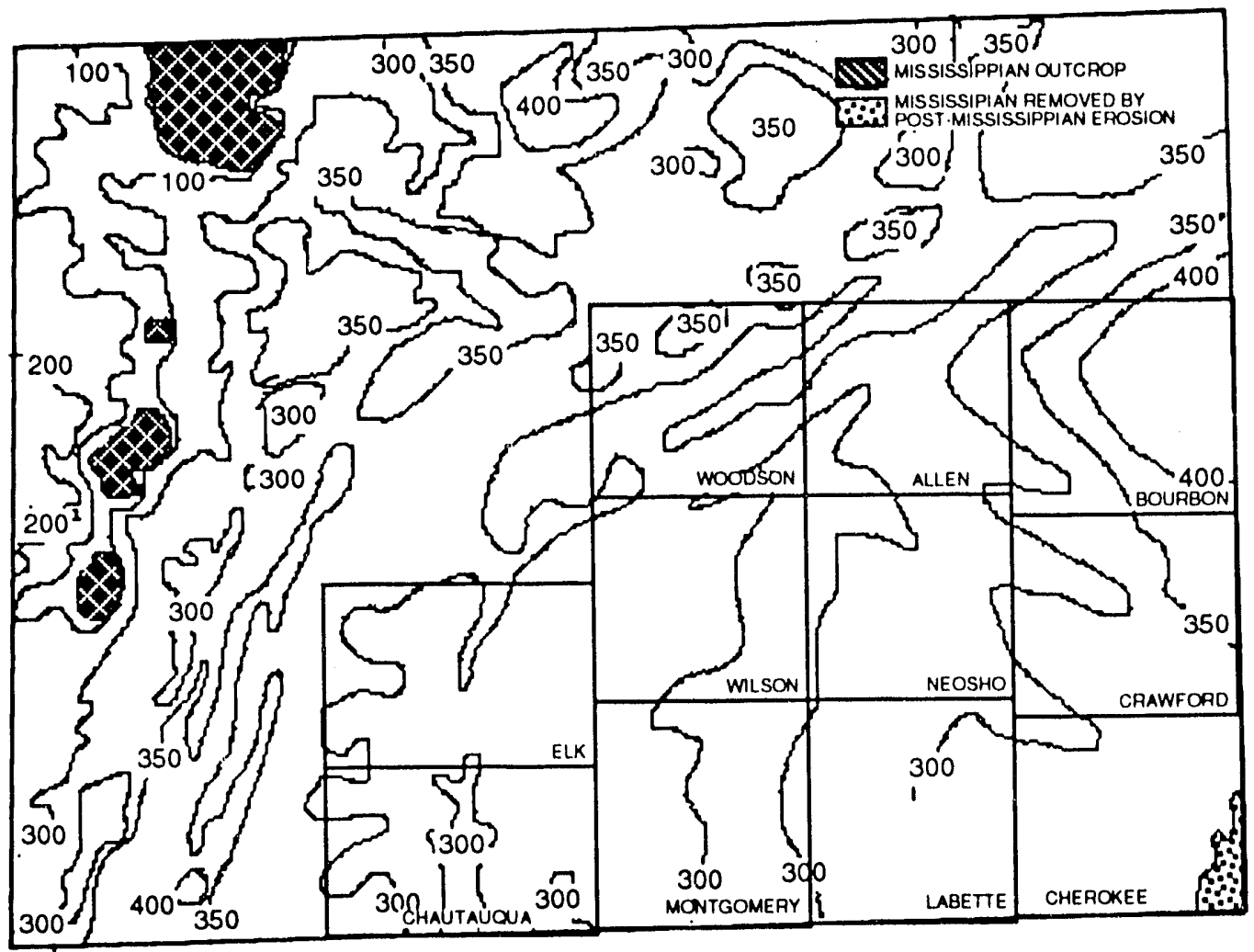

FIGURE 2.28. - Isopachous Map of "Mississippi Lime" in Southeastern Kansas. Note North- to Northeast-Trending Thick and Thin Areas, Which Coincide with Known Synclines and Anticlines. Contour Interval is 50 ft (from Merriam, 1983). 


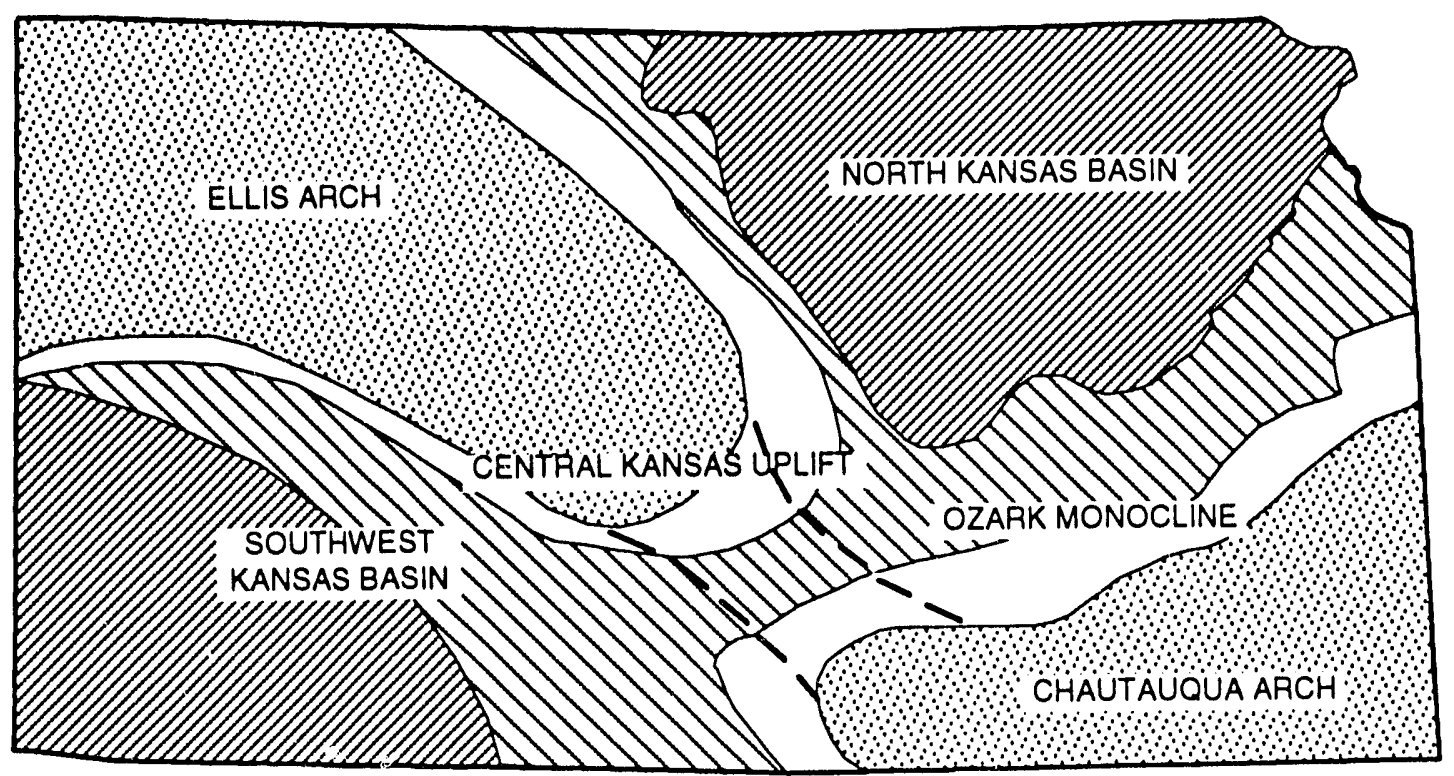

FIGURE 2.29. - Sketch Map Showing Main Structural Elements in Kansas During Mississippian Time (Jewett, 1979).

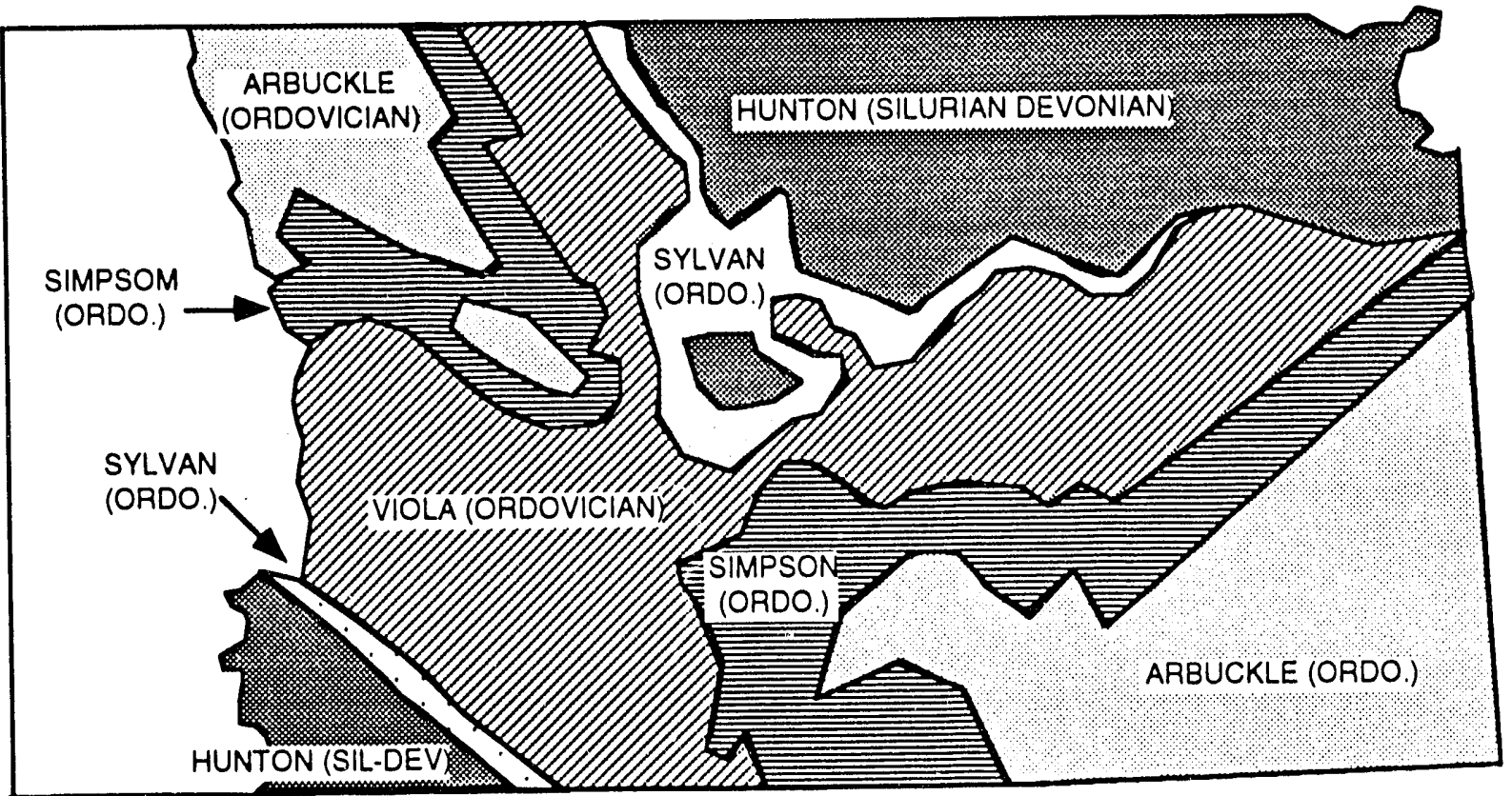

FIGURE 2.30. - Sketch Map of Kansas Showing Inferred Post-Devonian Pre-Mississippian Areal Geology (from Jewett, 1979). 


\begin{tabular}{|c|c|c|c|c|c|}
\hline \multirow{2}{*}{\begin{tabular}{|c|} 
TIME \\
MM \\
YEARS \\
\end{tabular}} & & & \multicolumn{3}{|c|}{ ROCK-STRATIGRAPHIC UNITS } \\
\hline & SYSTEM & SERIES & STAGE & LITHOLOGY & $\begin{array}{c}\text { LIMESTONE } \\
\text { FORMATION } \\
\text { (UNLESS SPECIFIED) }\end{array}$ \\
\hline 320 & PENNSYLVANIAN & & & & \\
\hline \multirow{4}{*}{340} & \multirow{4}{*}{ MISSISSIPPIAN } & \multirow[b]{2}{*}{ UPPER } & CHESTERIAN & & UNNAMED \\
\hline & & & MERAMECIAN & 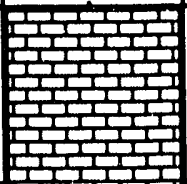 & $\begin{array}{l}\text { STE. GENEVIEVE } \\
\text { ST. LOUIS } \\
\text { SALEM } \\
\text { WARSAW }\end{array}$ \\
\hline & & \multirow[b]{2}{*}{ LOWER } & OSAGEAN & 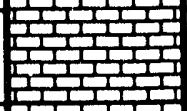 & $\begin{array}{l}\text { REORUK } \\
\text { BURLINGTON } \\
\text { EERN GLEN }\end{array}$ \\
\hline & & & KINDERHOOKIAN & & $\begin{array}{c}\text { GILMORE CITY } \\
\text { SEDALIA DOLOMITE } \\
\text { CHOUTEAU } \\
\text { BOICE SHALE }\end{array}$ \\
\hline 360 & DEVONIAN & UPPER & & & CHATTANOOGA SHAL \\
\hline
\end{tabular}

FIGURE 2.31. - Generalized Lithostratigraphic Column of Mississippian Formations in Kansas (from Ebanks, 1979).

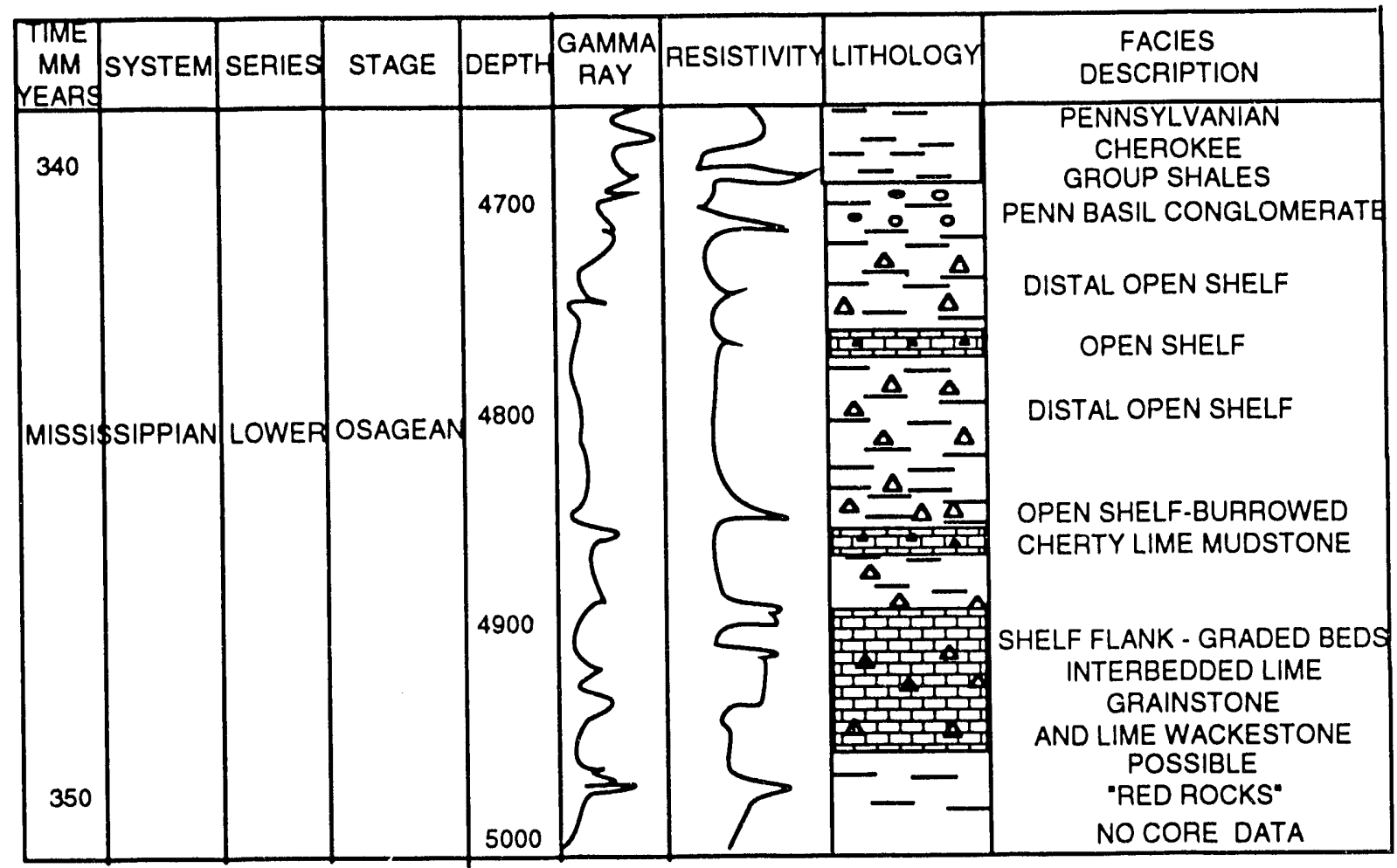

FIGURE 2.32. - Composite Stratigraphic Section of the Osagean Series. Lithology Versus Geophysical Log Response. Type Well KBW Oil Property Management, \#1 McCracken (from Thomas, 1982). 
Mississippian section just below the sub-Pennsylvanian unconformity (Figs. 2.30, 2.33, 2.34, and 2.35) (Adler, 1971). Solution weathering of Mississippian limestone commonly produces a residual chert zone that is known as the Mississippian "Chat" by drillers. The "Chat" is thickest in
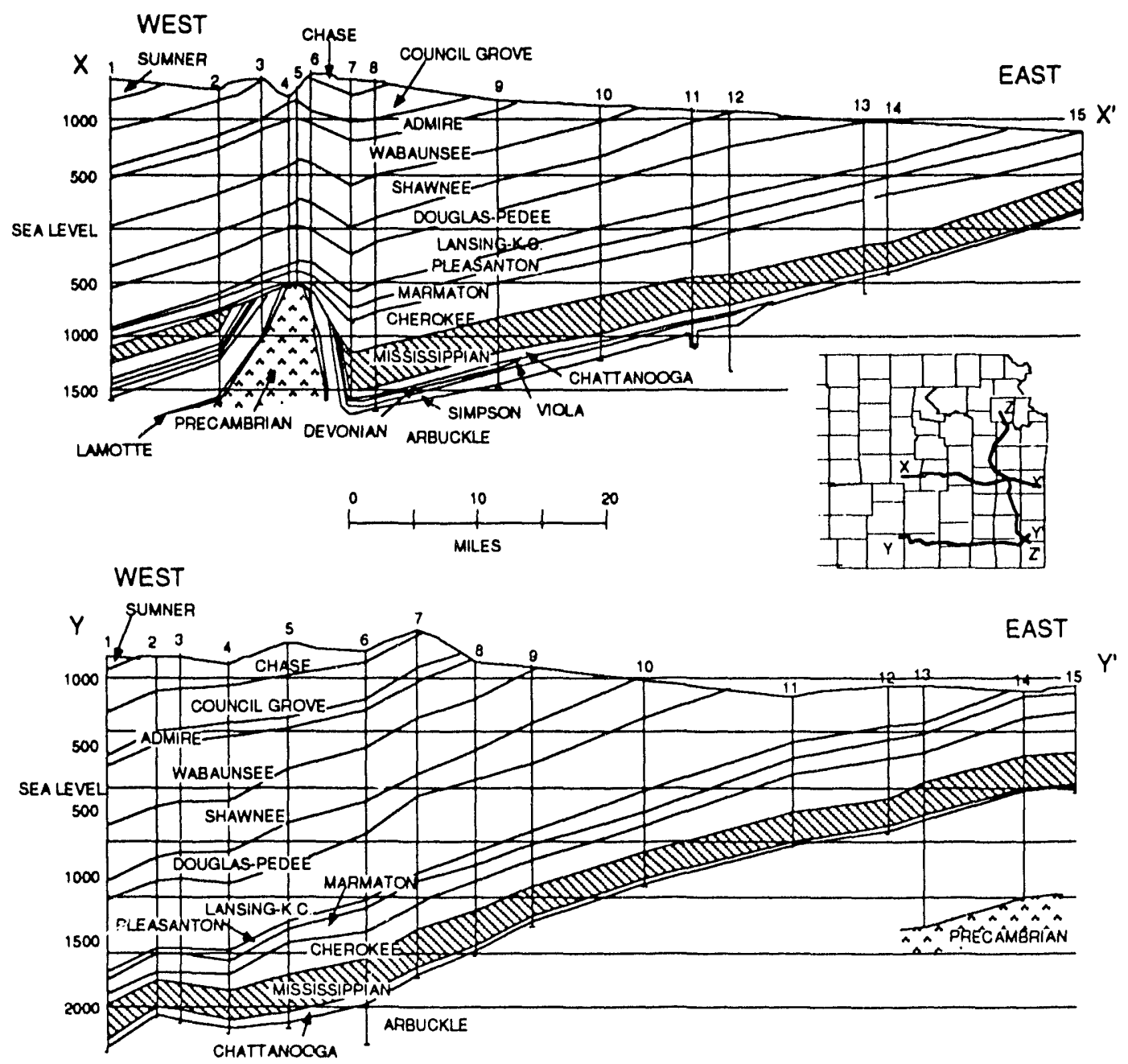

NORTHWEST

SOUTHEAST

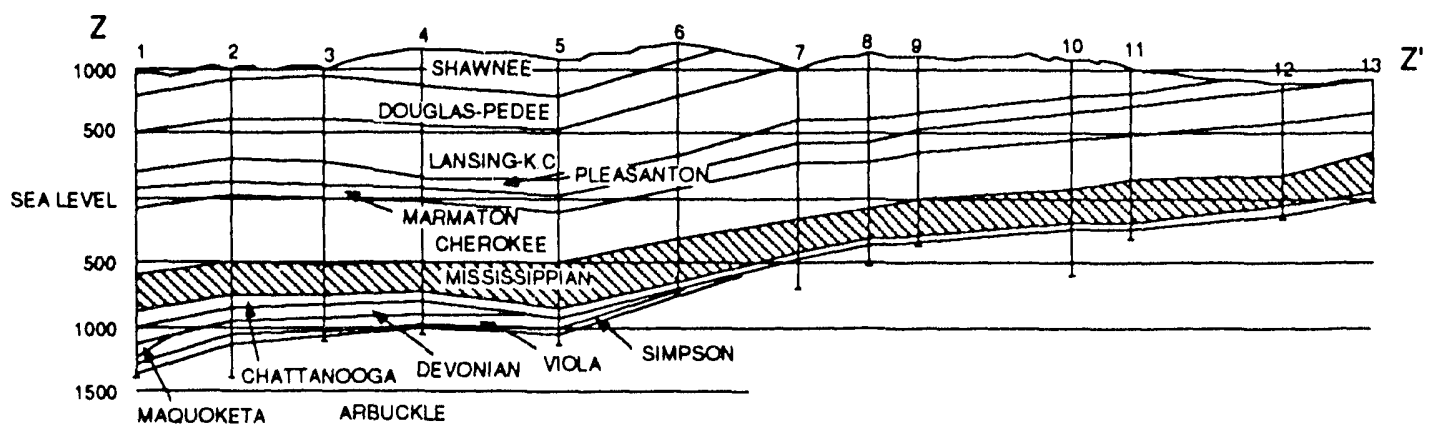

FIGURE 2.33. - Structural Cross Sections in Eastern Kansas Showing Relation of Mississippian Deposits to Younger and Older Units (from Merriam, 1983). 


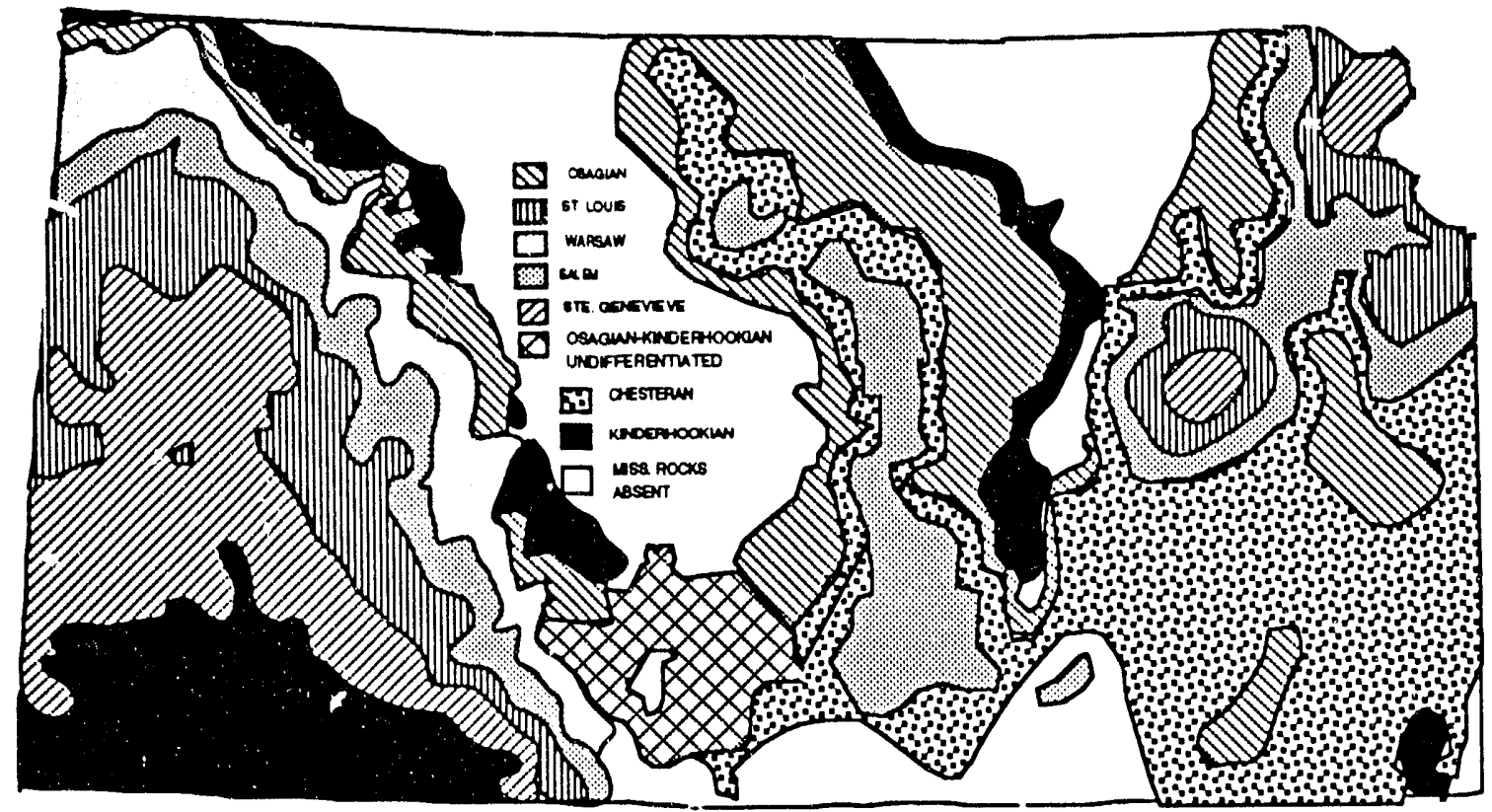

FIGURE 2.34. - Map of Kansas Showing Generalized Distribution of Mississippian Units Below Pennsylvanian Deposits. Area of Controversial Cowley Formation is Shown in South-Central Kansas (from Merriam, 1983).

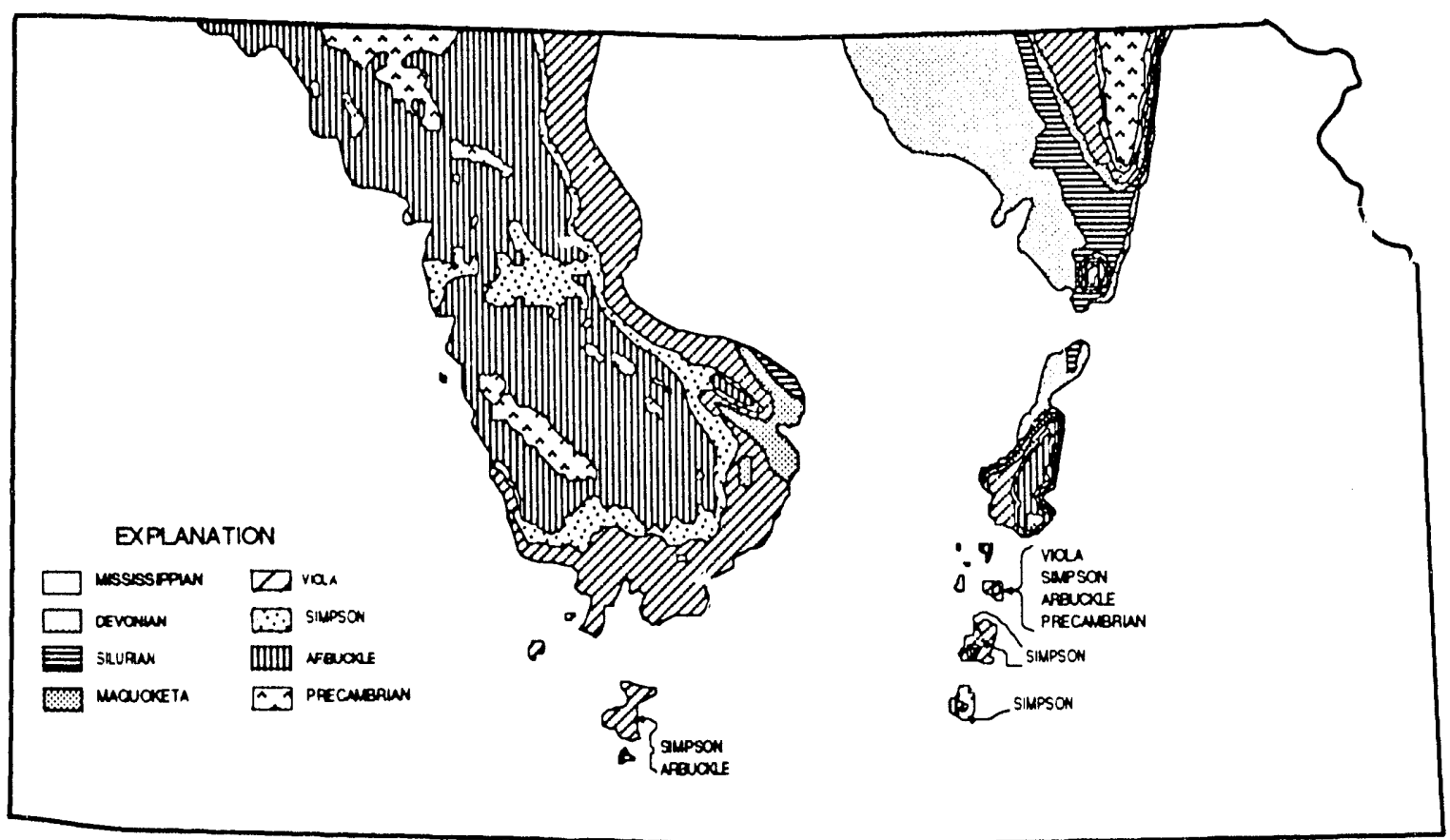

FIGURE 2.35. - Map of Kansas Showing Rocks Underlying Pennsylvanian Beds. Mississippian Rocks are Present Except on Nemaha Anticline, Central Kansas Uplift, Cambridge Arch, and Pratt Anticline, Where Rocks as Old as Precambrian Underlie Pennsylvanian (from Merriam, 1983). 
the vicinity of the Central Kansas uplift and the Pratt anticline. Reservoir characteristics in the "Chat" can be quite variable and difficult to predict. Mississippian "Chat" is difficult to distinguish from the overlying basal Pennsylvanian conglomerate that also serves as an oil reservoir. Mississippian oil fields are found on structural and combination structural-stratigraphic traps (Adler, 1971; Newell, 1987).

\section{PENNSYLVANIAN PERIOD}

\section{Morrowan and Atokan Groups}

Sediments of the Morrowan and Atoka Groups were deposited during earliest Pennsylvanian time (Fig. 2.3). Two oil fields (neither major) produce heavy oil from Morrow sediments in Kansas. Morrowan and Atoka age sediments were either not deposited or eroded in the Cherokee and Forest City basins (Figs. 2.1, 2.36, 2.37, 2.38, and 2.39). Therefore, eliminating a large part of the state as having potential reservoirs in rocks of this age. These rocks are also primarily gas reservoirs in southwestern Kansas. Ebanks et al. (1977) places the lower Warner sandstone in the Cherokee Group, Pennsylvanian Period rather than placing it as a member of the Riverton Formation, Atokan Group, Pennsylvanian Period as Wells and Anderson (1968) did in their heavy oil sand study of southwestern Missouri. The lower Warner sandstone of Kansas will be treated as a member of the Cherokee Group after Ebanks et al., (1977) in the discussion for Kansas in this report.

Atoka sediments do not produce oil or gas in Kansas. Gas is produced from Morrow age reservoirs in southwestern Kansas counties of Clark, Meade, Seward, Stevens, and Morton. Oil is produced from Morrow age reservoirs northward of these counties in a triangular pattern with the apex in Wallace county (Newell et al., 1987).

The embayment in which Morrow and Atoka sediments were deposited covers western Kansas and Oklahoma, the Texas Panhandle, and eastern Colorado. These sediments wedge out eastward and northward through Cheyenne, Kansosto, Clark, and Comanche counties Kansas (Newell et al., 1987). Maximum thickness in Kansas is in excess of $500 \mathrm{ft}$ (Roscoe and Adler, 1983). Morrow and Atoka sediments were deposited onto a pre-Pennsylvanian eroded surface (Fig. 2.36). Prior to deposition of Pennsylvanian sediments, older rocks were uplifted and eroded. As a result of this erosion, Pennsylvanian sediments were deposited on rocks that are Mississippian through Cambrian periods in age.

Lower Morrow reservoirs, referred to as "Keys sandstones," were deposited as beach, barrier-island, and offshore-marine sand bars (McManus, 1959; Adams, 1964; Khaiwka, 1973; Franz, 1984; Roscoe and Adler, 1984). These rocks are lenticular, ranging from poor to wellsorted, very fine- to coarse-grained, glauconitic, fossiliferous, clean quartz to feldspar-rich 

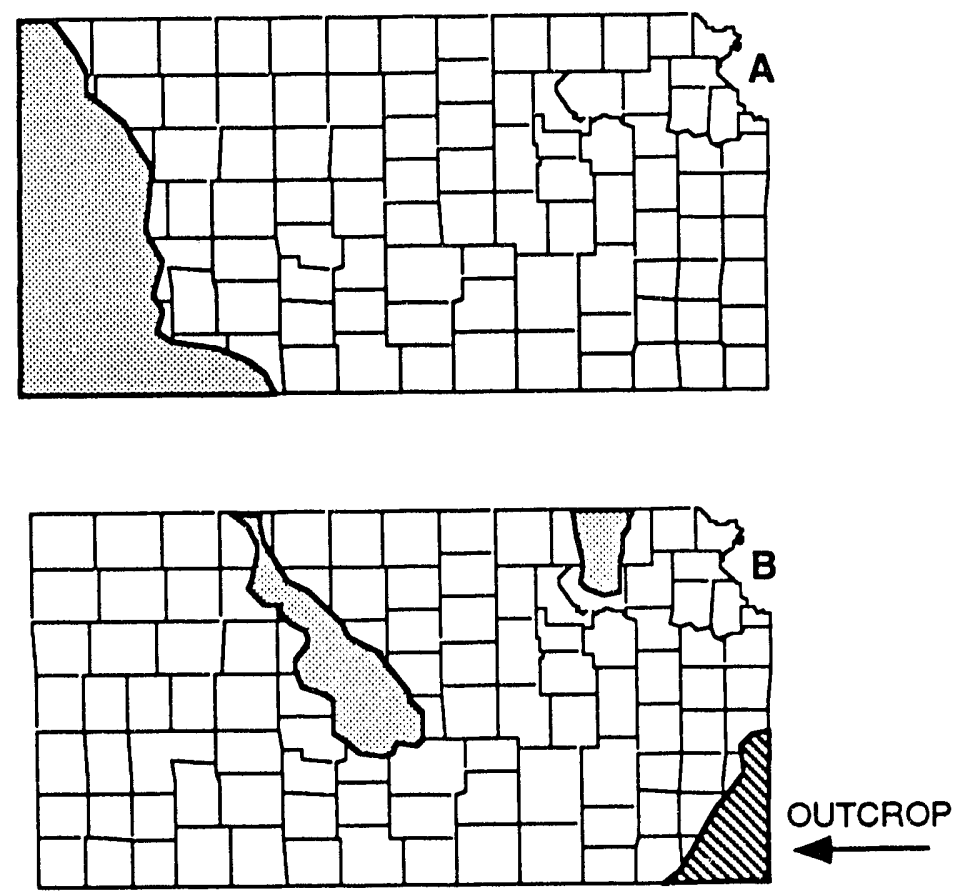

FIGURE 2.36. - Subsurface Distribution of Lower Pennsylvanian Rocks in Kansas. A. Morrowan and B. Desmoinesian and Atokan (from Merriam, 1983).

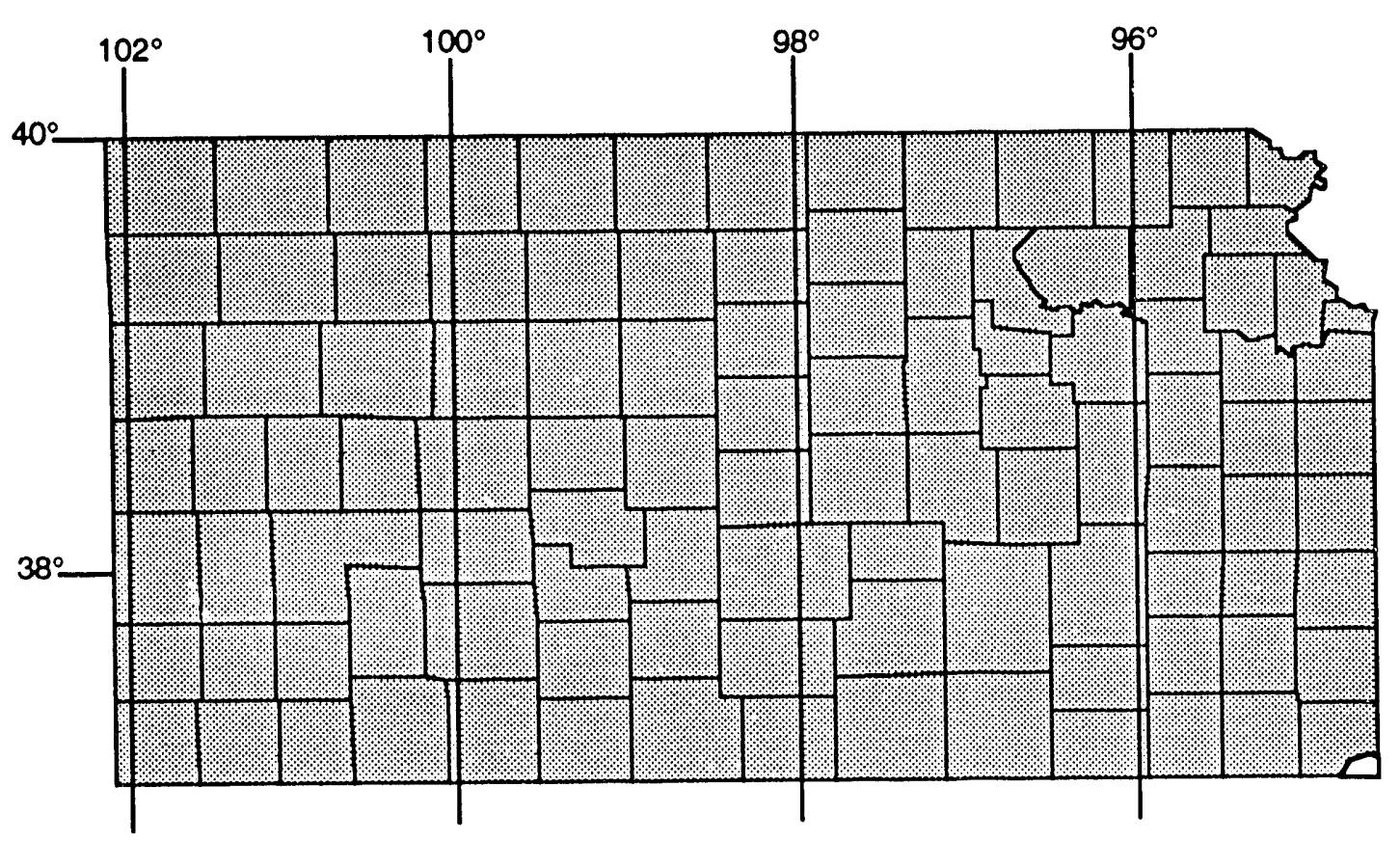

FIGURE 2.37. - Map of Kansas Showing Surface and Subsurface Distribution of Pennsylvanian Deposits (from Merriam, 1983). Not absent in southeast Kansas. 


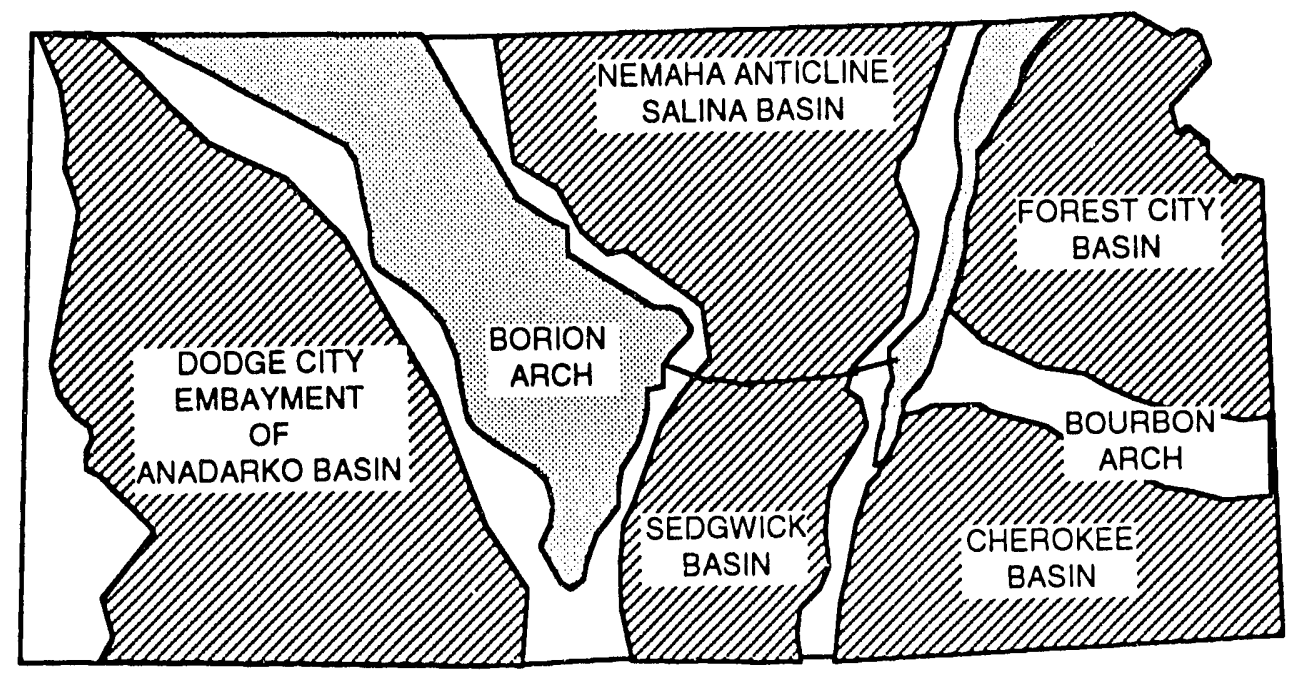

FIGURE 2.38. - Sketch map Showing Early Pennsylvanian Structural Provinces in Kansas (from Jewett, 1964).

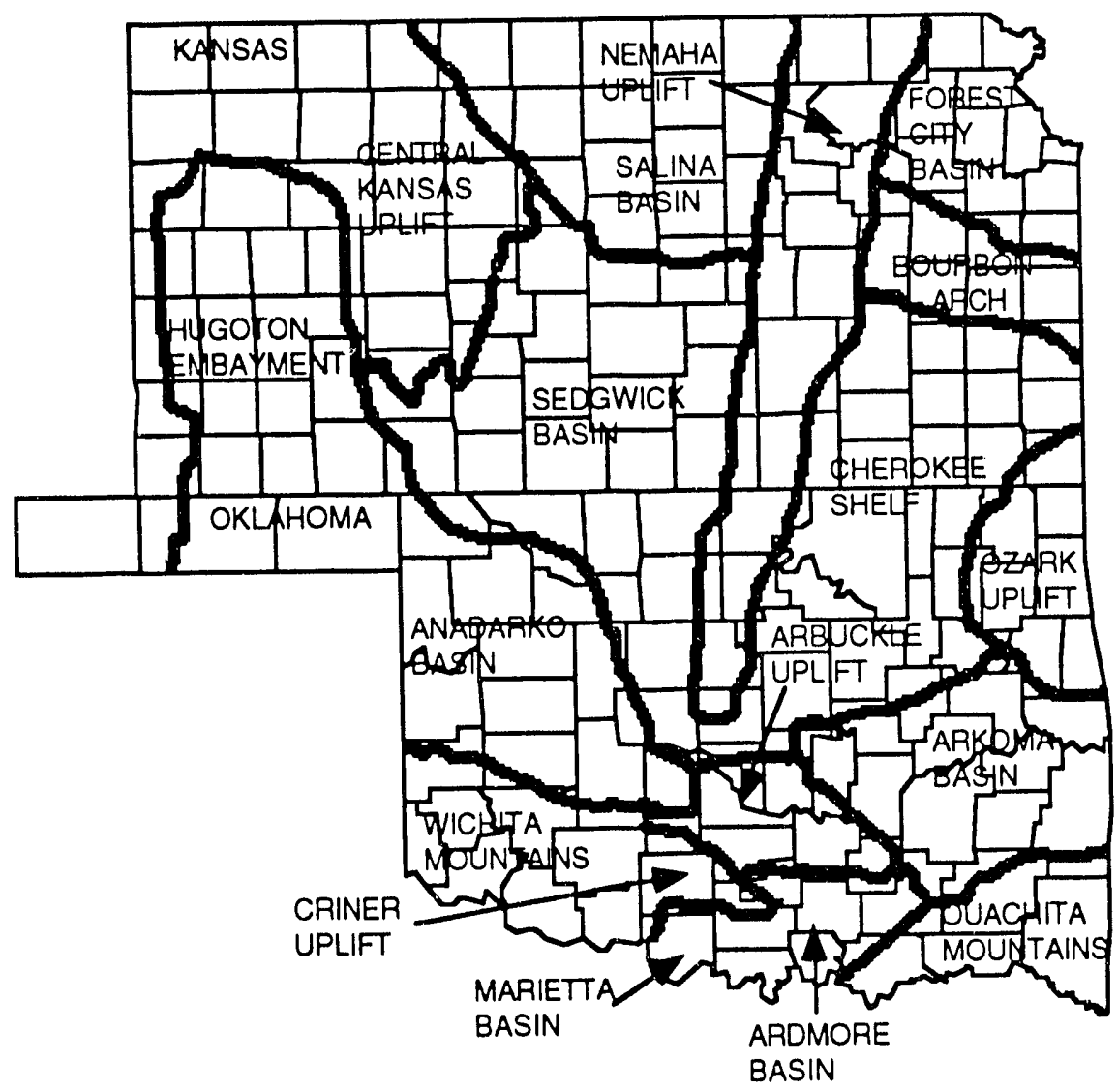

FIGURE 2.39. - Pennsylvanian Tectonic Settings in Kansas and Oklahoma (from Brenner, 1989). 
sandstone commonly containing pore filling calcite, dolomite, quartz, and kaolinite or chlorite clay minerals (Franz, 1984). Upper Morrow reservoirs were deposited by fluvial-deltaic systems during a still-stand or minor regression. Stream-mouth bar, distributary-channel, and fluvial pointbar sandstones have been identified as upper Morrow reservoir rock (Swanson, 1979; Franz, 1984). These coarse-grained, locally conglomeratic, cross-bedded sandstones commonly have calcite cement, clay minerals, and plant fossils (Newell et al., 1987).

Upper Morrow lenticular sandstone oil and gas reservoirs range in thickness from 2 to $60 \mathrm{ft}$. Trapping mechanisms for Morrow age reservoirs are structural and structuralstratigraphic. Multiple producing zones sometimes occur in Morrow age fields (Newell et al., 1987).

\section{Cherokee and Marmaton Groups}

The Cherokee and Marmaton Groups are members of the Desmoinesian Stage, Middle Pennsylvanian Period (Figs. 2.2, 2.3, and 2.40). There are 15 Cherokee Group and 4 Marmaton Group reservoirs listed as heavy oil ( $10^{\circ}$ to $25^{\circ}$ API gravity) producers in the annual oil and gas production reports compiled by the Kansas Geological Survey. Only Iola field is a major field.

The Cherokee and Forest City basins east of the Nemaha uplift have large areas that produce oil and gas from Cherokee Group and Marmaton Group sandstones. Another large area that produces oil from these rocks is west of the Central Kansas Uplift. Oil reservoirs from these rocks are also scattered across southwest Kansas and the Pratt anticline in south-central Kansas (Figs. 2.1 and 2.41) (Newell et al., 1987).

The Cherokee Group was deposited prior to deposition of the Marmaton Group. The Marmaton Group consists of repeated sequences (cyclotherms) of shale, lenticular sandstones, thin coals, and minor limestones (Figs. 2.42 and 2.43). This sedimentary sequence is dominated by fluvial-deltaic rocks with minor terrestrial and open-marine rocks. Major occurrences of oil in eastern Kansas occur in marine bar deposits and meandering alluvial-stream deposits with abundant lesser oil accumulations in distributary-channel and crevasse-splay deposits in successive deltaic depositional systems (Fig. 2.44) (Rich, 1923; Rich, 1926; Bass, 1934; Huse, 1979; Harris, 1985; Newell et al., 1987). Oil and gas that commonly accumulates in updip areas of these sediments are classified as combination structural-stratigraphic traps (Busch, 1959; Newell et al., 1987).

Fining-upward, medium- to very-fine-grained, channel-filling, fluvial-deltaic sandstones up to $116 \mathrm{ft}$ in thickness are reservoirs for oil accumulations in eastern Kansas. These channel-filling sandstones are commonly made up of five lithofacies, a lower facies composed of three lithofacies 


\begin{tabular}{|c|c|c|c|c|c|c|c|c|c|}
\hline \multirow{2}{*}{\begin{tabular}{|c|} 
TIME \\
MM \\
YEARS \\
\end{tabular}} & \multirow[b]{2}{*}{ SERIES } & \multirow[b]{2}{*}{ STAGE } & \multirow[b]{2}{*}{ GROUP } & \multicolumn{2}{|c|}{ FORMATION } & \multicolumn{4}{|c|}{ STRATIGRAPHIC INTERVALS } \\
\hline & & & & $\begin{array}{l}\text { JEWETT } \\
\text { (1959) }\end{array}$ & $\begin{array}{l}\text { HOWE } \\
\text { (1956) }\end{array}$ & $\begin{array}{l}\text { EBANKS } \\
\text { ET AL. } \\
(1977) \\
\end{array}$ & $\begin{array}{l}\text { HULSE } \\
(1978)\end{array}$ & $\begin{array}{c}\text { KILLEN } \\
(1986)\end{array}$ & $\begin{array}{l}\text { STATON } \\
(1987)\end{array}$ \\
\hline \multirow{14}{*}{315} & \multirow{14}{*}{ 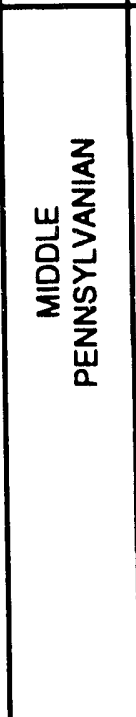 } & \multirow{14}{*}{ 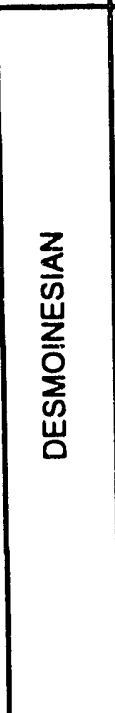 } & \multirow{14}{*}{$\begin{array}{l}\text { 岀 } \\
\frac{\mathbf{y}}{0} \\
\frac{\mathbb{1}}{\mathbf{T}} \\
\frac{T}{U}\end{array}$} & \multirow{8}{*}{ CABANIS } & $\frac{\text { EXCEIIO }}{M \| 1 \mathrm{KY}}$ & \multirow{4}{*}{ LAGONDA } & \multirow{3}{*}{ SQUIRREL } & \multirow{3}{*}{$\begin{array}{c}\text { UPPER } \\
\text { CHEROKEE }\end{array}$} & \multirow{3}{*}{$\begin{array}{l}\text { EXCELLO } \\
\text { BEVIER }\end{array}$} \\
\hline & & & & & LAGONDA & & & & \\
\hline & & & & & BEVIIER & & & & \\
\hline & & & & & $\begin{array}{l}\text { VERDIGRIS } \\
\text { CODWERIIRG }\end{array}$ & & VERDIGRIS & VSHALE & VSHALE \\
\hline & & & & & HEMING & \multirow{2}{*}{$\begin{array}{l}\text { MIDDLE } \\
\text { CABANIS }\end{array}$} & \multirow{2}{*}{ CATTLEMAN } & \multirow{2}{*}{ MINERAL } & MINERAL \\
\hline & & & & & $\frac{\text { MINEBAL }}{\text { SCAMMON }}$ & & & & SCAMMON \\
\hline & & & & & TEBO & \multirow{3}{*}{$\begin{array}{l}\text { LOWER } \\
\text { CABANIS }\end{array}$} & SKINNER & TEBO & TEBO \\
\hline & & & & & WEIR & & & WEIR-PITTSBURC & PITSBUBG \\
\hline & & & & \multirow{6}{*}{ KREBS } & \begin{tabular}{|l} 
SEVILLE \\
BIUE
\end{tabular} & & BURBANK & UPPEA BLUUACKEI & \multirow{6}{*}{ BLUEJACKET I } \\
\hline & & & & & JACKET & BLUE & BART FSVIUL & \multirow{5}{*}{ KREBS } & \\
\hline & & & & & $\frac{\text { DRYWOOD }}{\text { ROWE }}$ & JACKEI & & & \\
\hline & & & & & & UPPER & & & \\
\hline & & & & & WARNEH & WANNEH & & & \\
\hline & & & & & RIVERTON & & & & \\
\hline
\end{tabular}

FIGURE 2.40. - Stratigraphic Classifications of the Cherokee Group in Southeastern Kansas (modified after Staton, 1987).

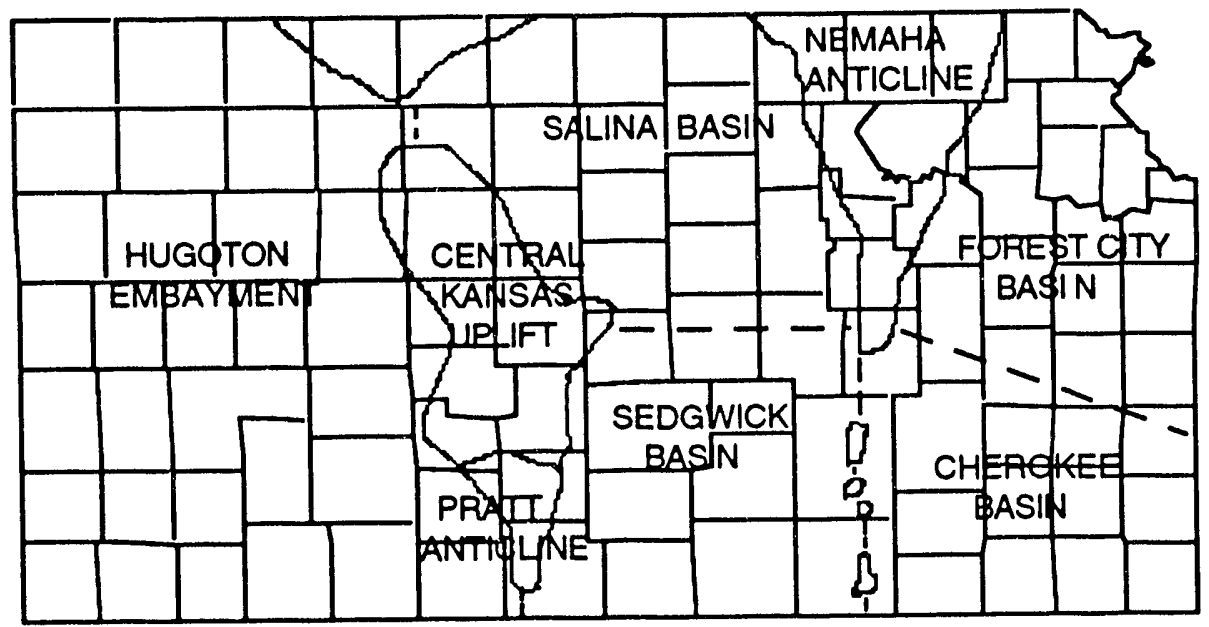

FIGURE 2.41. - Major Post-Mississippian-Pre-Desmoinesian Structural Elements of Kansas (from Thomas, 1982). 


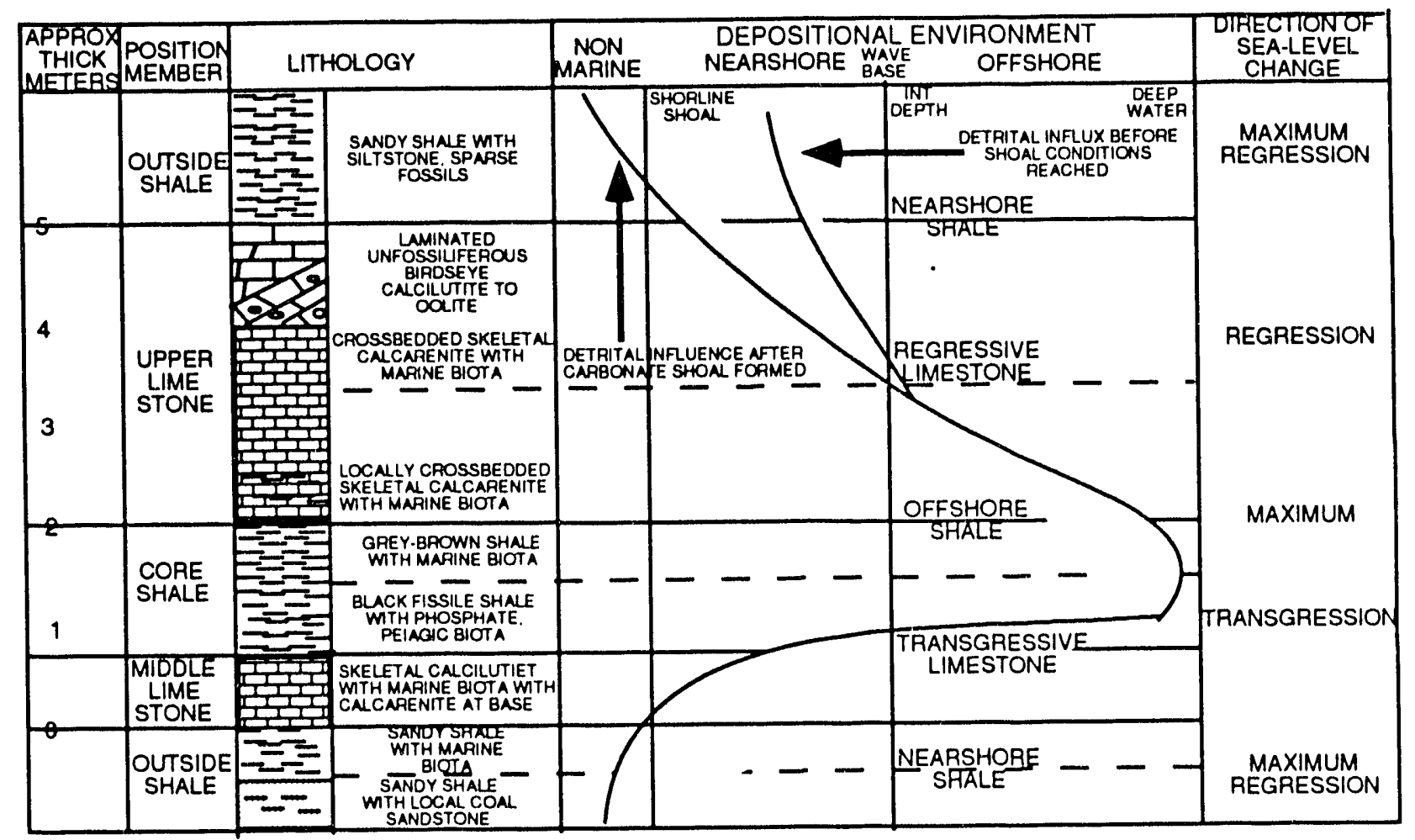

FIGURE 2.42 - Basic Vertical Sequence of an Individual Kansas Pennsylvanian Cyclotherm, Which is Generally Characteristic of Marmaton, Kansas City, Lansing, and Shawnee Groups, Showing Lithology and Interpreted Environments and Phases of Deposition (from Ebanks, 1979).

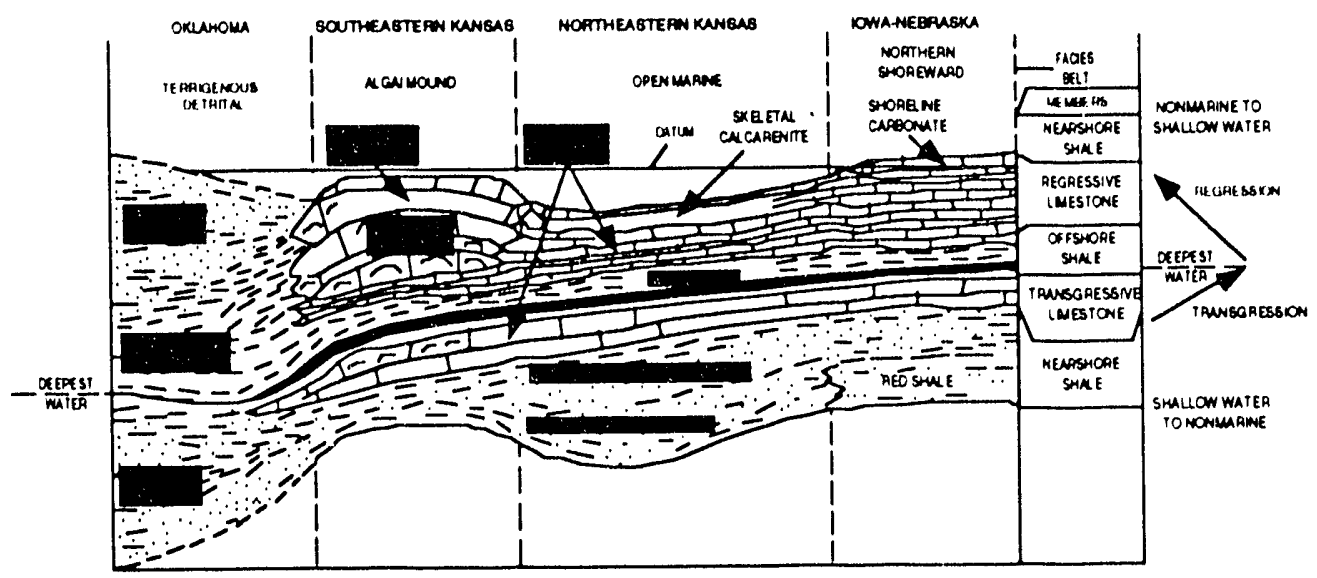

FIGURE 2.43. - Basic Pattern of Laterai Facies Relations in Generalized Kansas Cyclothem Across Facies Belts Exposed Along Midcontinent Outcrop. Datum is Interpreted Approximate Sea Level at Time That Increased Detrital Influx Terminated Deposition of Regressive Limestone Member (from Ebanks, 1979). 


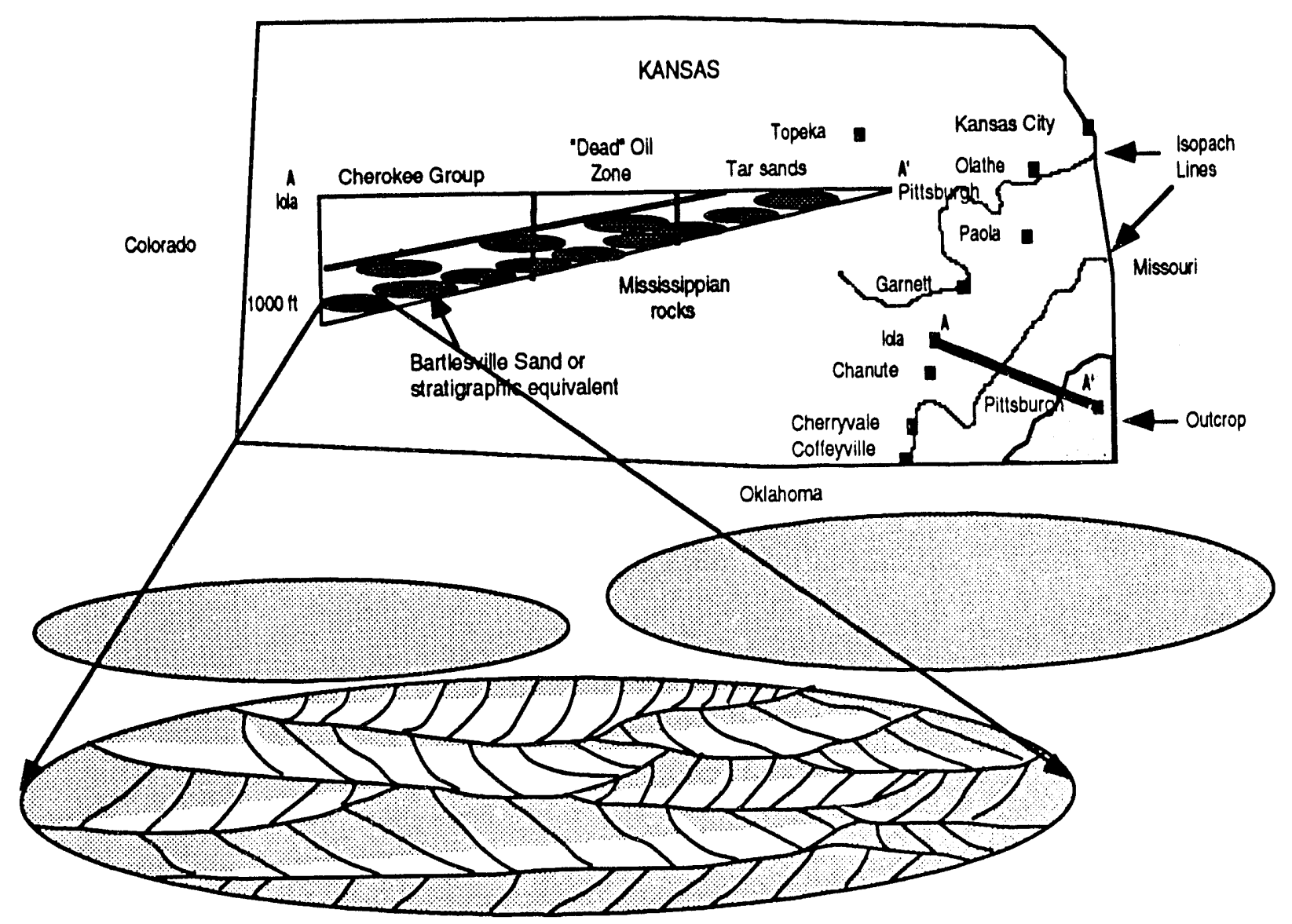

FIGURE 2.44. - Area of Low Gravity $\left(18^{\circ}\right.$ to $\left.22^{\circ}\right)$, Oil and Tar Sands in Eastern Kansas (from Goebel, 1966). Expansion of sand lens (Johnson and Olsen, 1993).

(Fig. 2.45) (1) basal conglomeratic sandstones, (2) crossbedded coarser sandstones and (3) an upper facies composed of two lithofacies (a) rippled finer sandstone and (b) interbedded sandstones, shales, and siltstones. These sandstones may be capped by conglomeratic sandstones. Mineralogy of these sandstones is generally the same throughout eastern Kansas, dominantly quartz with lesser amounts of feldspars, mica, and sedimentary and metamorphic rock fragments (Woody, 1984; Walton et al., 1986; Worthington, 1982).

Cherokee Group sandstones are dominated by those deposited as channel-filling, multistoried, multiple-stacked, discontinuous, fining-upward, multiple-point-bar deposits in channels cut into underlying older Pennsylvanian and/or Mississippian rocks. Channels where these sandstones were deposited were commonly no larger than about $1,300 \mathrm{ft}$ in width at any given time. Many Cherokee Group fields are much wider than 1,300 ft at present, due to deposition and 


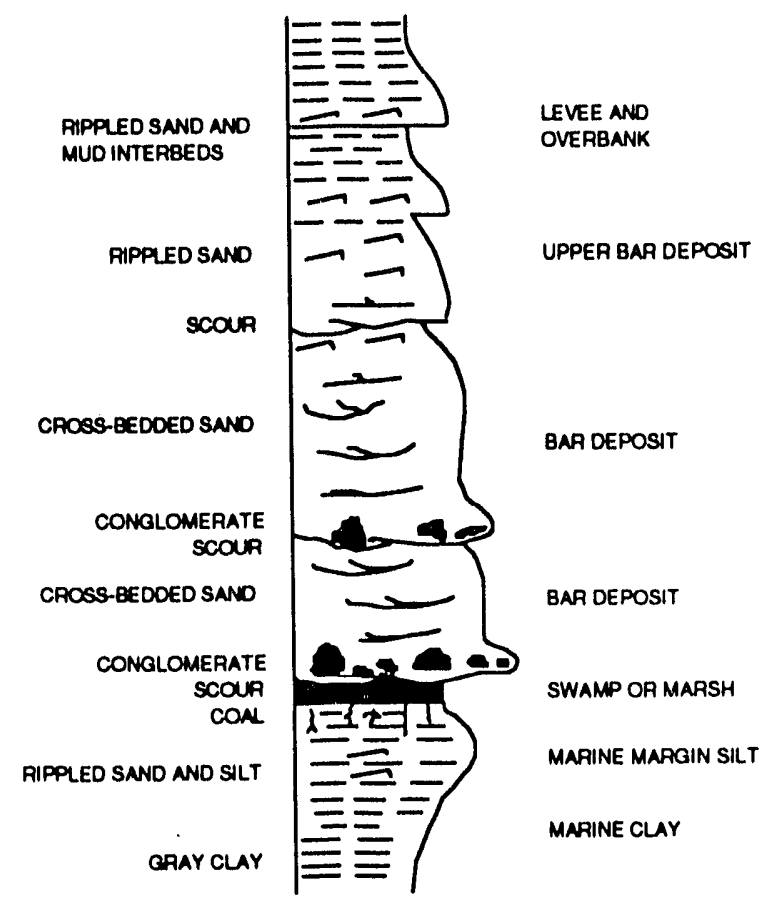

FIGURE 2.45. - Vertical Succession of Facies in Cherokee Fluvial Shoestring Sandstones. Intervals Between Scour Surfaces Range Up to $45 \mathrm{ft}$. Thick, Commonly They Are $30 \mathrm{ft}$. or Less (from Walton et al., 1986).

stacking of sand bodies as the stream meandered across the flood plain, but were probably no larger than about $1,300 \mathrm{ft}$ at any given time during their depositional history. The larger fields are made up of multiple sand bodies (correlating as the same sandstone) that have filled in a stream channel that was eroding while filling with multiple-point-bar sandstone deposits (Johnson and Olsen, 1991).

Ultimate recovery of oil from reservoirs in Cherokee Group sandstones is affected by the compartmentalization (intemal architecture), small scale sedimentary structures, bedding boundary and intergranular small scale permeability barriers, and diagenetic changes, commonly noted as heterogeneities, within the sandstone body. Lower sandstone facies will probably have the largest volume of economically recoverable oil during primary, waterflood, and/or enhanced oil recovery phases of production. Upper sandstone facies that are part of the oil reservoir will contribute small quantities of oil throughout the productive life of the reservoir, but will be produced on a less costeffective basis (Figs. 2.46 and 2.47) (Johnson and Olsen, 1991).

The upper facies of these sandstones commonly contain oil entrapped in discontinuous depositional compartments. This compartmentalization is affected by both depositional conditions 


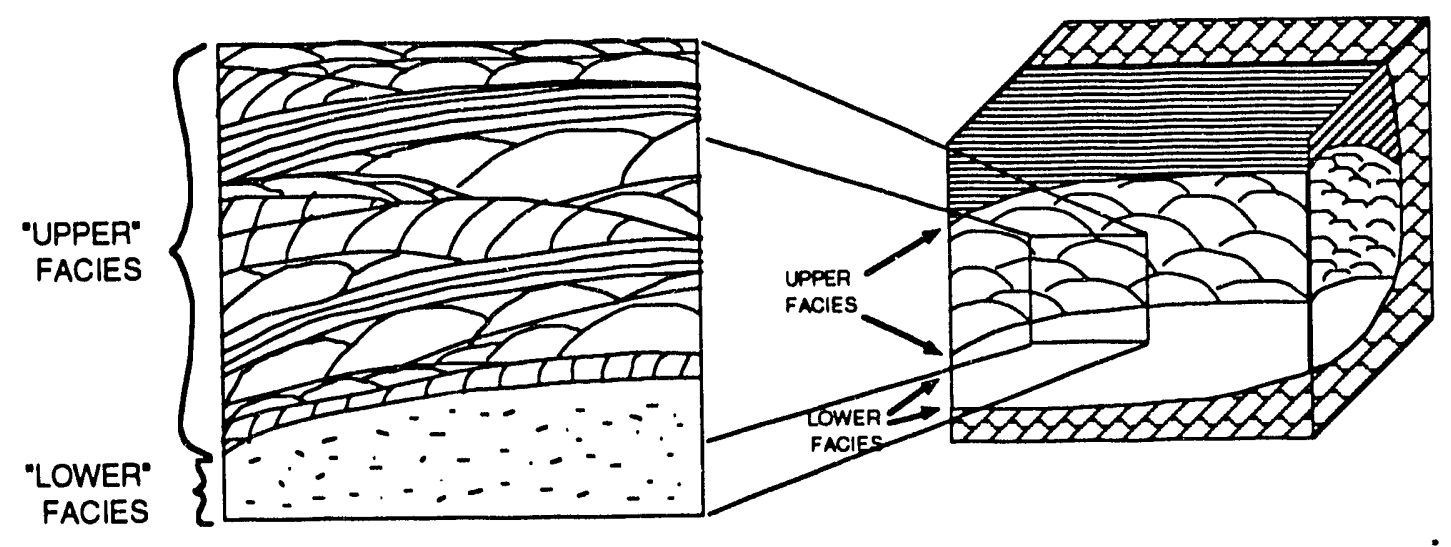

FIGURE 2.46. - Cross Section of Fluvial-Dominated Deltaic Channel Sand Showing Upper Facies (Continuous and Discontinuous Between Wells) Compartment and Lower Facies (More Continuous Sand) (from Johnson and Olsen, 1991).
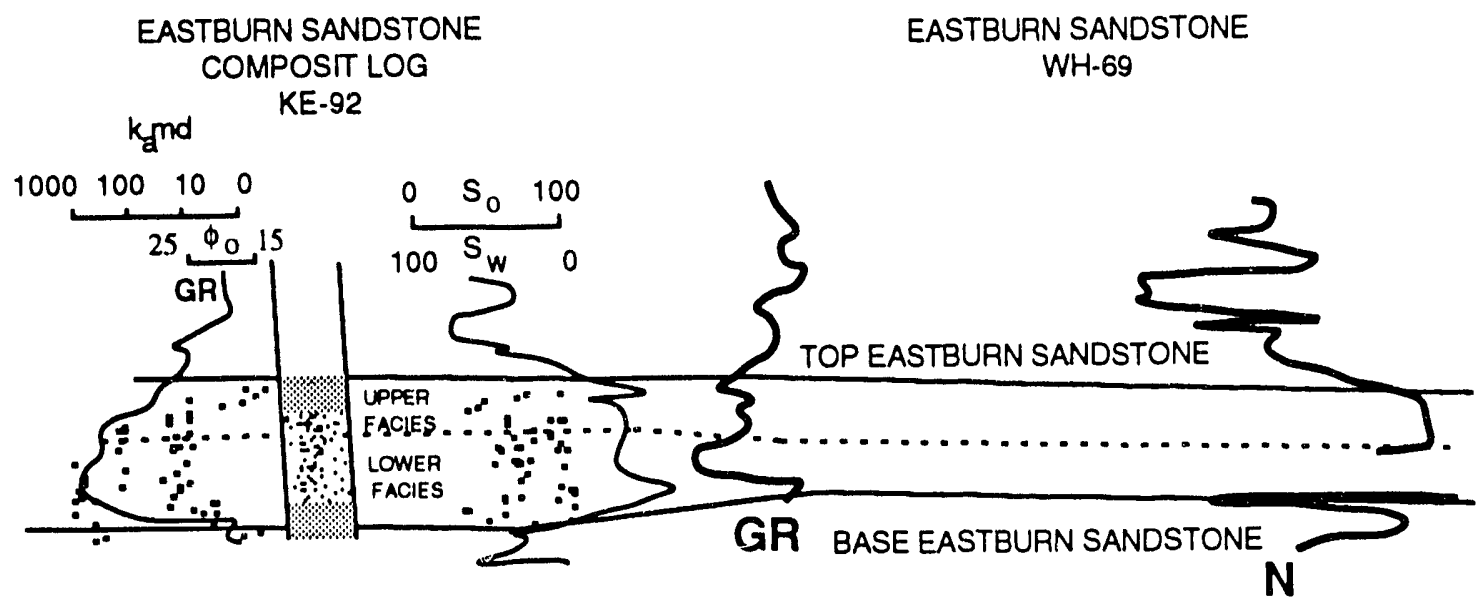

FIGURE 2.47. - Correlation of a Composite Log of Well KE-92 (GR-N Log-Lithology Log-Core Analysis) with Well Log of WH-69, Eastburn Sandstone, Eastburn Field, Vernon County, Missouri (from Johnson and Olsen, 1991).

and diagenetic changes. Depositional compartmentalization is caused by sandstone lenses with spatial variation smaller than the prevailing well spacing $(10,20,40$, or 80 acres). Spatial variation of depositional compartmentalization may be 1 acre or less. Bedding boundary and intergranular small scale permeability barriers are associated with depositional compartmentalization. Bedding boundary permeability barriers are formed by early, partial to almost complete cementation of very-fine-grained sediment deposited along boundaries of sand lenses. Small-scale intergranular permeability barriers may be formed by precipitation of diagenetic clays or by clay or shale pebbles deposited with sandstone grains (Fig. 2.46). 
Depositional compartmentalization and bedding boundary and small-scale intergranular permeability barriers are commonly noted as reservoir "heterogeneities" (Johnson and Olsen, 1991; Johnson and Olsen, 1993).

Diagenetic changes in Cherokee Group sandstone reservoirs affect oil recovery. These changes occurred in three stages. During Stage 1, precipitation of calcite concretions and spherulitic siderite resulted in nearly complete loss of porosity and permeability in scattered patches within the sandstones. During Stage 2, chlorite was precipitated as grain coatings. Precipitation of varying degrees of silica cement was inversely related to the presence of chlorite grain coatings, chlorite coated grains were not well cemented. Sand grains coated with chlorite in lower facies portions of channel-filling sandstone inhibited precipitation of silica cement, preserving part of the primary porosity. In upper facies of these sandstones, the lack of chlorite coating and compaction permitted extensive precipitation of silica cement, reducing porosity and permeability. During Stage 3, kaolinite, siderite, and dolomite-ankerite cements were precipitated in patches. Deposition of these minerals with precipitation of carbonate cements caused additional reduction in porosity and permeability. Secondary porosity was created during all three stages by dissolution of feldspars, micas, and argillaceous rock fragments (Fig. 2.48) (Woody, 1984; Walton et al., 1986; Worthington, 1982).

During diagenesis of these sandstones, fine- and very-fine-grained sediments were cemented first while coarser sediments were coated with chlorite. This sequence of precipitation caused finer-grained material at the bedding boundaries of upper facies sandstone to become cemented first (Woody, 1984; Worthington, 1982). Oil migrated into these sandstones after these diagenetic changes occurred. If hydrocarbons had migrated during or prior to diagenesis, limited alterations in porosity and permeability would have occurred (Worthington, 1982). This cementation in upper facies sandstone is a primary cause for depositional compartmentalization of oil in this facies. Depositional compartmentalization of oil in upper facies sandstone is a primary cause that oil in this facies is not swept during all phases of oil recovery. Diagenetic changes in reservoir rock affect reservoir storage capacity for oil and ultimate oil recovery from both heavy and light oil reservoirs. Sweep efficiency, thief zones (high permeability streaks), some depositional compartments, etc. in light and heavy oil reservoirs are affected and/or created by diagenetic changes to reservoir rock (Johnson and Olsen, 1991).

In western Kansas, the Cherokee Group, particularly in the upper part, becomes more marine with limestone replacing fluvial deltaic sandstones. Cherokee Group sediments were deposited on pre-Pennsylvanian erosional surface around the flanks and on the crest of the Central Kansas uplift. These sediments pinch-out locally around the flanks of the Central Kansas uplift. In the lower Cherokee Group, valley filling lenticular sandstones were deposited by rivers on the flanks 


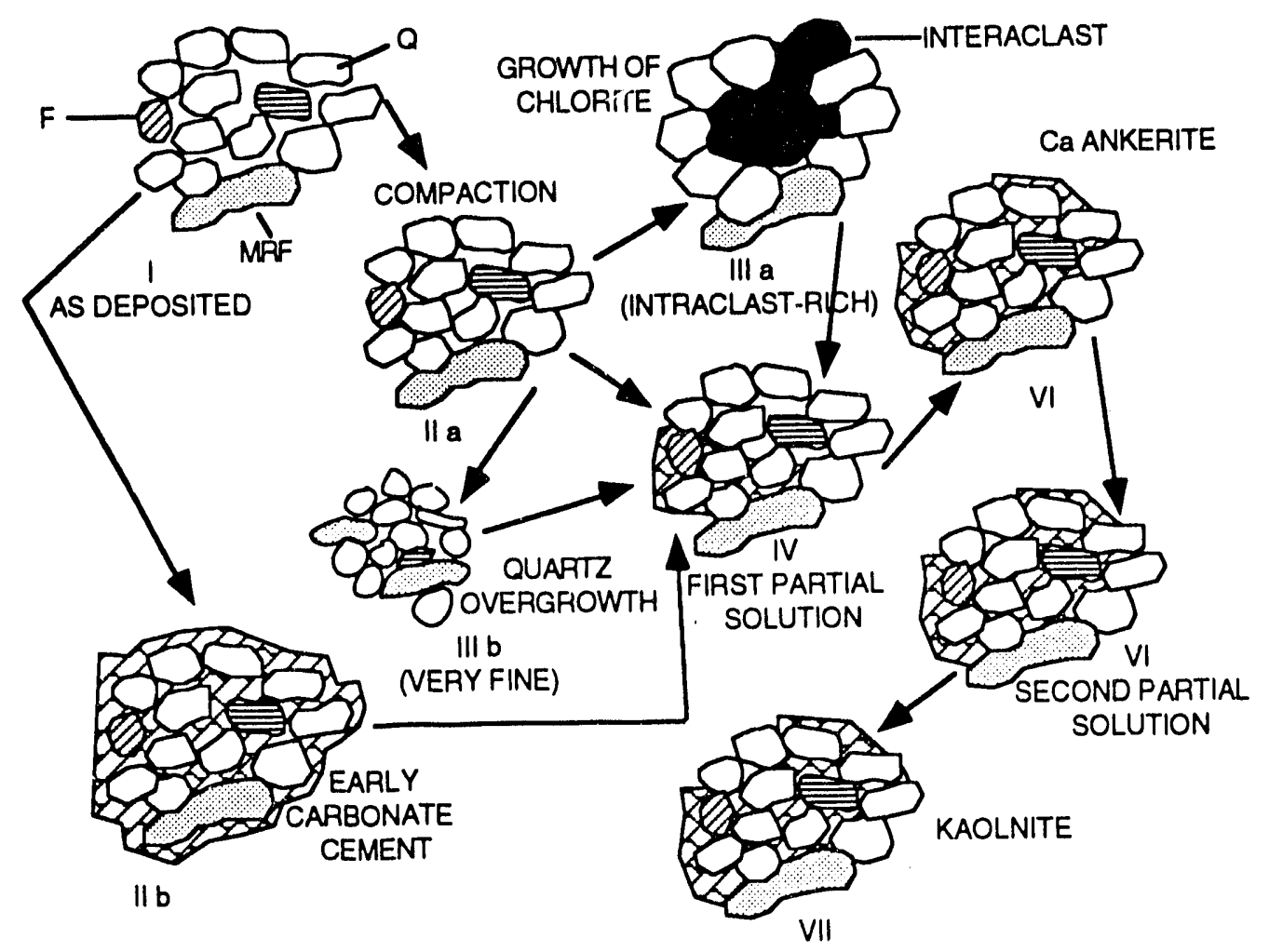

FIGURE 2.48. - Diagenetic Sequence in Cherokee Sandstone Reservoirs. Evidence for the second Period of Dissolution and the Relative Order of Formation of Kaolinite and Ca-Ankerite is equivocal (from Walton et al., 1986).

of the Central Kansas uplift. Basal Pennsylvanian conglomerates that range in age up to Missourian were deposited around uplifts. The oldest conglomerates are on the lower flanks of uplifts, becoming progressively younger toward the crests of uplifts. Pre-Pennsylvanian uplifts were the source for basal Pennsylvanian conglomerates. These conglomerates were deposited directly on Precambrian and Arbuckle erosional surfaces around uplifts (Newell et al., 1987).

Marmaton and Cherokee limestones are oil productive across western Kansas. The productive units of these limestones are regressive (upward-shallowing) components of cyclotherms. Exposure to weathering during late development of cyclotherms altered and leached high energy carbonate deposits such as oolitic limestones or mud-dominated carbonate buildups. Dissolution of carbonates after burial of carbonates resulted in the formation of porosity which may cause significant impact to local reservoir development in Marmaton and Cherokee limestones (Caldwell, 1985; Daniels, 1985; Newell et al., 1987).

Cherokee Group "shoestring" sandstones in eastern Kansas are known by a variety of names: Bartlesville (Bluejacket), Squirrel, Warner, Burgess, Lagonda, Cattleman, Burbank, Cabanis, Riverton, upper Cherokee, Krebs, and Penn-Basal Conglomerate. These sandstones are 
productive from stratigraphic, structural, and structural-stratigraphic traps. A common range of dimensions of these reservoirs is up to $55 \mathrm{ft}$ in thickness, $1,000 \mathrm{ft}$ to 2,000 ft in width, and as much as 14 miles in length. Desmoinesian sandstones have been the most productive reservoirs in the Midcontinent. Cherokee Group sandstones are the oldest oil exploration and exploitation plays in the Midcontinent, having their beginning during the 1860s. Marmaton carbonates are also major reservoirs in the Midcontinent (Fig. 2.49) (Newell et al., 1987).

\section{Missourian Group}

Missourian Group sediments were deposited during the upper Pennsylvanian Period (Fig. 2.50). These reservoirs include those of the Lansing, Kansas City, and Pleasanton Formations. There are 16 oil fields reported to have heavy oil production in the annual oil and gas production report compiled and published by the Kansas Geological Survey.

Missourian age rocks are divided into Pleasanton, Kansas City, and Lansing groups, in ascending order (Fig. 2.50). Pleasanton sediments are composed of shales and lenticular sandstones. These sandstones were deposited by a fluvial deltaic system. Locally, in the Cherokee and Forest City Basins of eastern Kansas, reservoirs in Pleasanton rocks are referred to as Hepler and Knobtown sandstones (Fig. 2.1) (Newell et al., 1987).

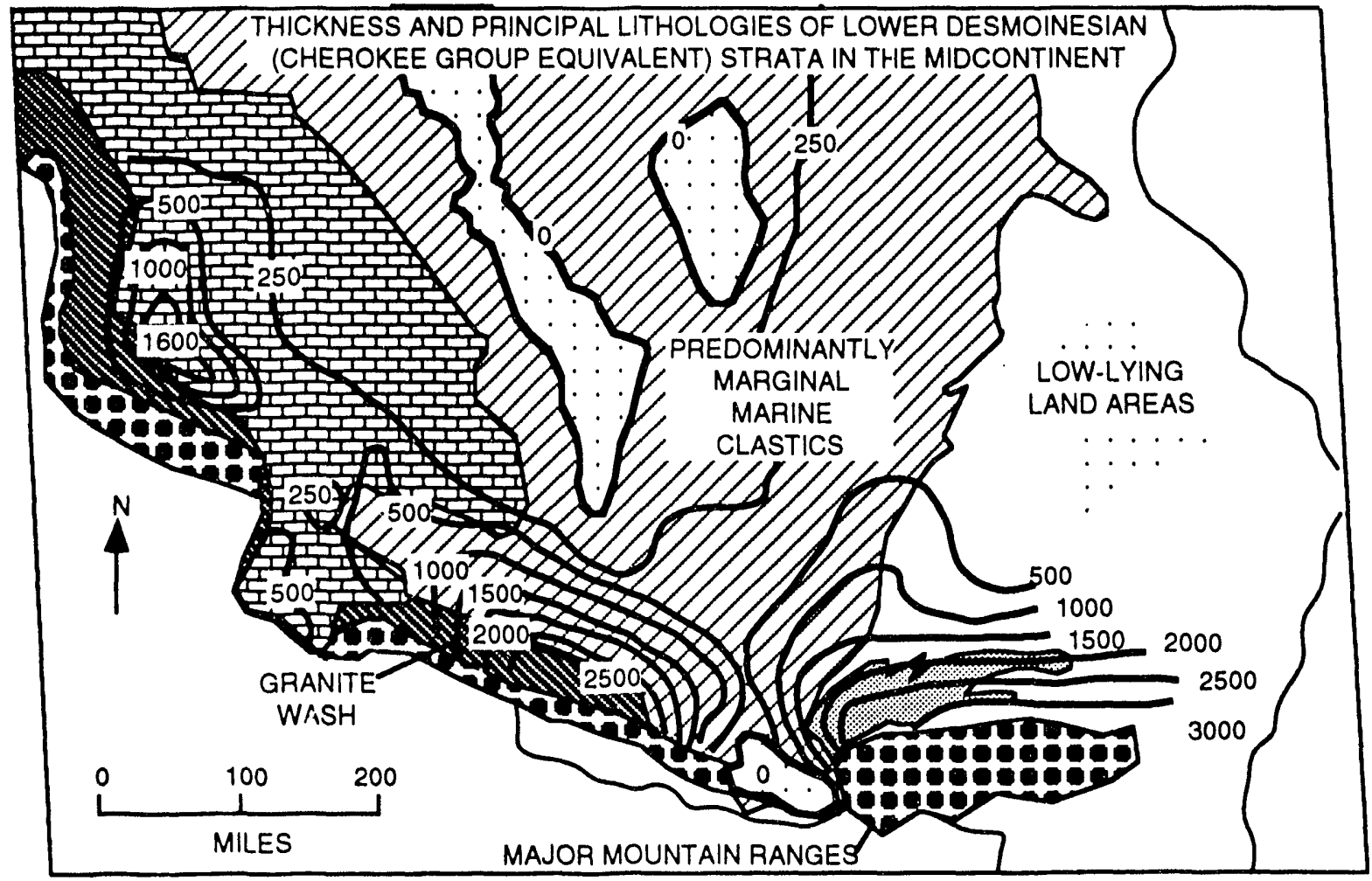

FIGURE 2.49 - Thickness and Principal Lithologies of Lower Desmoinesian (Cherokee Group Equivalent) Strata in the Midcontinent (from Harris, 1984). 


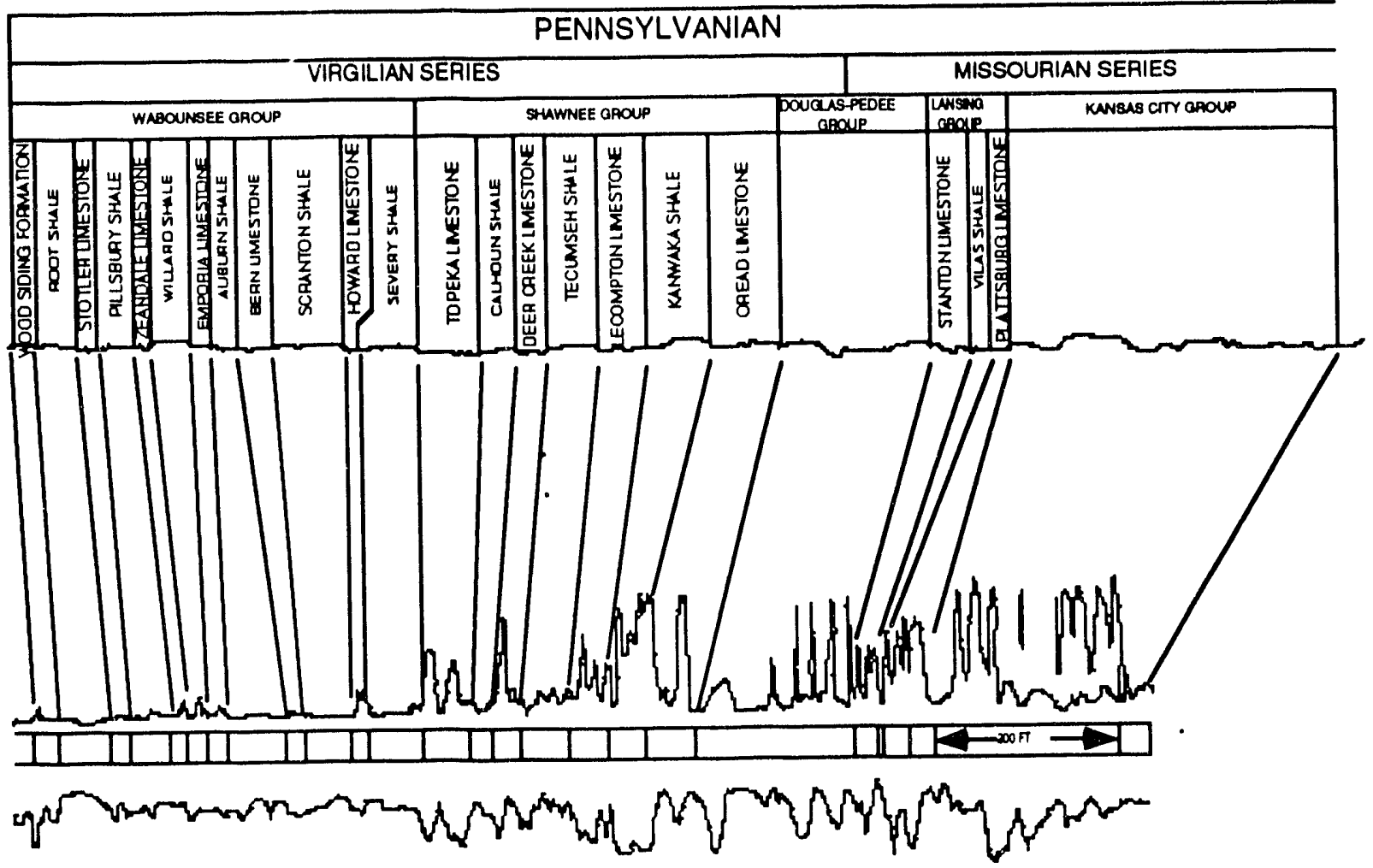

FIGURE 2.50 - Stratigraphic Column Missourian and Virgilian Series Pennsylvanian Period (from Merriam, 1963).

Kansas City and Lansing groups are made up of cyclotherms with regressive limestones as reservoir quality rocks (Figs. 2.42 and 2.43). In the subsurface in central and western Kansas, these two groups are referred to as the Lansing-Kansas City. They are the dominant Missourian age producing rocks in Kansas. The regressive limestones are grain-rich, shallowing-upward porous reservoir rock. The grain-supported fabric of this rock is the result of high-energy marine deposition near the top. These reservoir rocks were commonly exposed shortly after deposition, enhancing the original porosity and permeability of the regressive limestone. Lansing-Kansas City limestones produce on local, low relief structures (Fig. 2.51) (Watney 1980, 1984, 1986; Newell et al., 1987).

Oil production from Missourian reservoirs is widespread across western and central Kansas. It is concentrated over the Central Kansas uplift, but it is more scattered in adjacent basins (Fig. 2.1). These rocks also produce in southwest Nebraska, Oklahoma and Texas. Accumulations of oil and gas are found in structural, stratigraphic, and structural-stratigraphic traps in carbonates, sandstones and granite wash. Gas production is limited to extreme eastern Kansas and southwestern Kansas on the flanks of the Cimarron arch (Newell et al., 1987). 


\section{Virgilian Group}

Reservoirs of the Virgilian Group are Upper Pennsylvanian in age (figure 2.50). Douglas, Shawnee, and Wabaunsee Formations are reservoir rock for oil and gas fields in the Virgilian. Five fields produce heavy oil ( $10^{\circ}$ to $25^{\circ} \mathrm{API}$ gravity, none majo $)$ from these rocks according to annual oil and gas production reports compiled and published by the Kansas Geological Survey.

The Virgilian Stage is made up of rocks in the Douglas, Shawnee, and Wabaunsee groups in ascending order. These rocks are cyclotherms of limestones, shales, and minor sandstones (Figs. 2.42 and 2.43). Reservoir rock of the Shawnee and Wabaunsee groups are dominantly shallowing-upward, regressive limestones. Shawnee and Wabaunsee reservoir rocks are commonly in the Toronto, Topeka, and Howard limestones. Lenticular sandstones of the Douglas Group are dominantly in southern and southeastern Kansas. Douglas Group limestones, thickening from less than $50 \mathrm{ft}$ in northwest Kansas to greater than $400 \mathrm{ft}$ in southeast Kansas, are also reservoir rock. Douglas Group rocks were deposited in a marginal marine system in southern and southeastern Kansas. Thick sandstones of the Douglas Group pinch out northward onto a marine shelf in the western Sedgwick basin where there are abundant stratigraphic traps (Newell et al., 1987).

Oil and gas fields are found in Virgilian rocks associated with major structural features such as the Central Kansas uplift, the Pratt anticline, and portions of the Nemaha uplift (Figs. 2.1 and

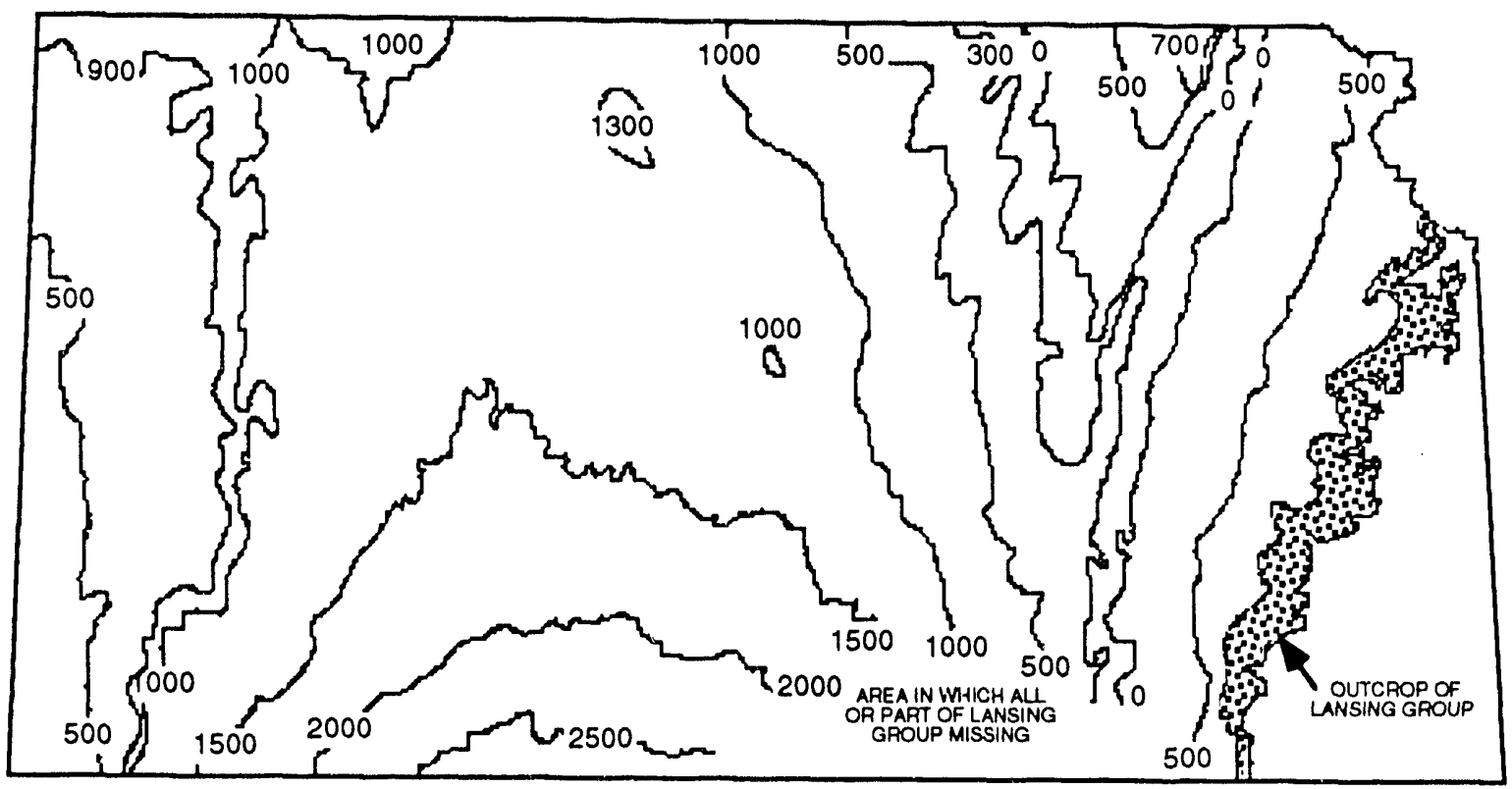

FIGURE 2.51 - Preliminary regional structural map contoured on top of Lansing Group (Missourian, Pennsylvanian) in Kansas. Contour Intervals are in feet (from Merriam, 1963). 
2.39). Fields are present in the Sedgwick basin and western Kansas. Oil production is concentrated in the northern portion of the Central Kansas uplift (Newell et al., 1987).

\section{STRUCTURAL FEATURES}

The Central Kansas uplift, Nemaha uplift, Humboldt fault system, Chautauqua arch, Pratt anticline, Cherokee basin, Forest City basin, Sedgwick basin, Hugoton basin, and Salina basin are major structural features and sedimentary basins in Kansas (Fig. 2.1). These features and basins have little or no surface expression. These features were recognized from drilling of exploratory tests for oil and/or gas as early as 1915. Since 1915, they have become defined and recognized as separate and distinct subsurface features (Newell et al., 1987). The Bourbon arch, trending to the northwest from Vernon County, Missouri into Kansas, separates the Cherokee and Forest City basins in eastern Kansas. It is a subsurface feature that extends from the Nemaha uplift in Kansas to the Ozark Dome in Missouri (Fig. 2.1). Moore and Jewett (1942) recognized and named the Bourbon arch.

The Central Kansas uplift and Nemaha uplift are major post-Mississippian structural highs recognized in the subsurface (Fig. 2.1). The Nemaha uplift was recognized as a dominant subsurface feature in 1915, and formally named in 1917 by Moore and Hanes in a treatise on Kansas oil and gas. The Nemaha uplift is a north-northeast-south-southwest oriented asymmetric, gently west dipping feature, extending from Nebraska across eastern Kansas into Oklahoma, bounded on the east by the Humboldt fault system. The eastern boundary of the Nemaha uplift marks the western boundary of the Cherokee and Forest City basins in eastern Kansas (Figs. 2.1 and 2.52) (Newell et al., 1987).

The Central Kansas uplift was recognized as a significant regional feature in the early 1920 s and named in 1932 by Nergab. It is a more symmetric northwest-southeast trending feature than the Nemaha uplift. Major oil fields are located on this structural feature. The Salina basin, named by Barwick in 1928, is located between the Central Kansas uplift and the Nemaha uplift (Fig. 2.1) (Newell et al., 1987).

The Pratt anticline extends southward from the Central Kansas uplift, separating the Hugoton and Sedgwick basins. The Hugoton basin, west of the Pratt anticline in southwest Kansas and the Sedgwick basin, east of the Pratt Anticline, are structural embayments on the northern flank of the Anadarko basin extending northward out of Oklahoma. Basement rocks are deepest $(-6,900 \mathrm{ft}$ subsea) on the Kansas-Oklahoma state line in the Hugoton basin in Mead County, Kansas (Figs. 2.10 and 2.52) (Newell et al., 1987).

The Central Kansas arch in south-central Kansas was the prominent structural feature in this region prior to geologic deformation in late Mississippian and early Pennsylvanian time. 


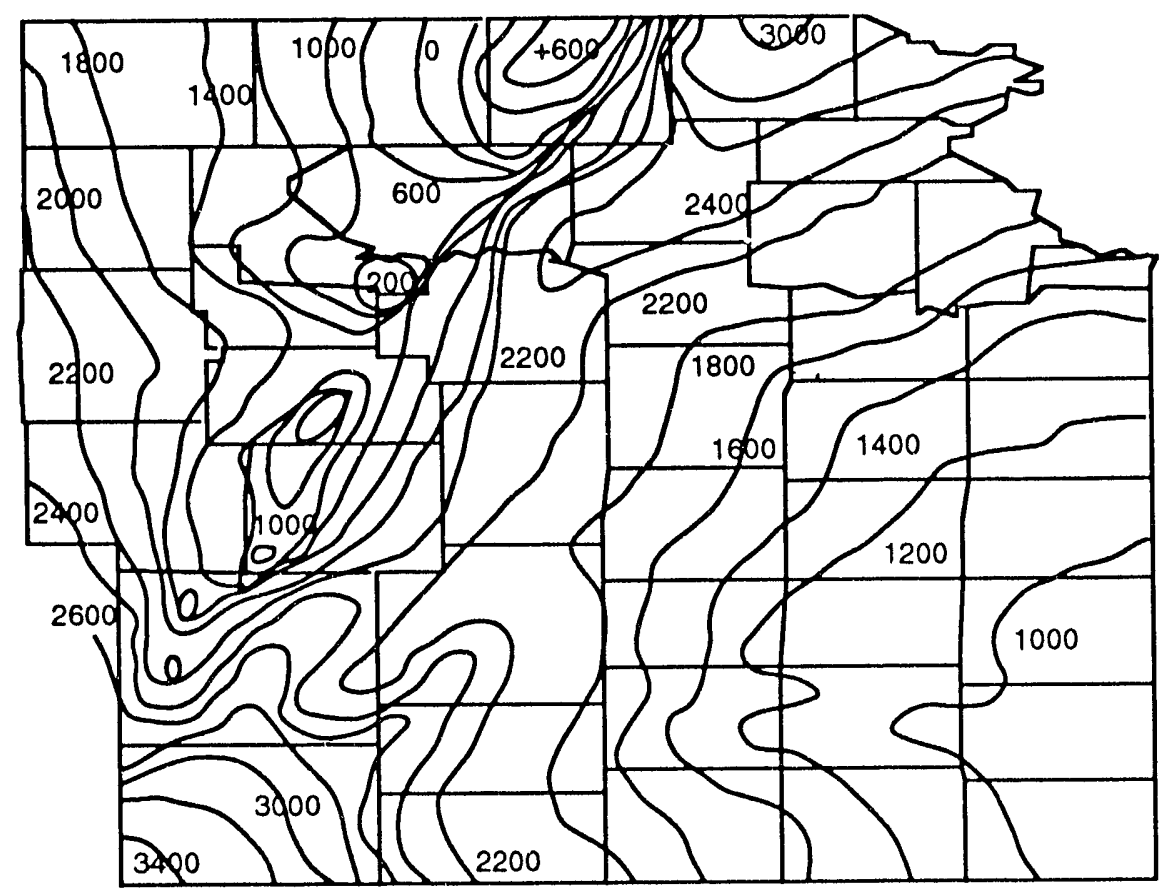

FIGURE 2.52. - Map of Eastern Kansas Showing the Approximate Configuration of the Upper Surface of Pre-Cambrian Rocks and Nemaha Uplift. Contour Intervals in feet are Drawn on Sea Level Datum (from Jewett, 1979).

Northwest and southeast extensions of this feature are respectively called the ancestral Central Kansas uplift and the Chautauqua arch (Figs. 2.1 and 2.16). The Central Kansas arch pre-dates the Nemaha and Central Kansas uplifts that were formed by geologic deformation during late Mississippian to early Pennsylvanian time (Merriam, 1963).

The North Kansas basin, named by Rich in 1933, was located north of the Central KansasChautauqua arch prior to geologic deformation that created the Nemaha uplift. With the formation of the Nemaha uplift, the North Kansas basin was split into the Forest City basin on the east and the Salina basin on the west. Pre-late Mississippian prominent structural features in Kansas are not recognizable because of the geologic deformation that occurred during late Mississippian-early Pennsylvanian time (Fig. 2.38) (Newell et al., 1987).

Natural fracturing occurs in Kansas sedimentary basins (Figs. 2.53 through 2.55). Primary orientation of fractures is generally in a northeast-southwest direction with a secondary set of fractures approximately perpendicular to the primary set. Many oil fields have reservoirs that are fractured by these natural fractures. Fracture patterns may be seen on the surface by examining areal photographs or by walking over the surface. Natural fractures may connect an oil or gas 


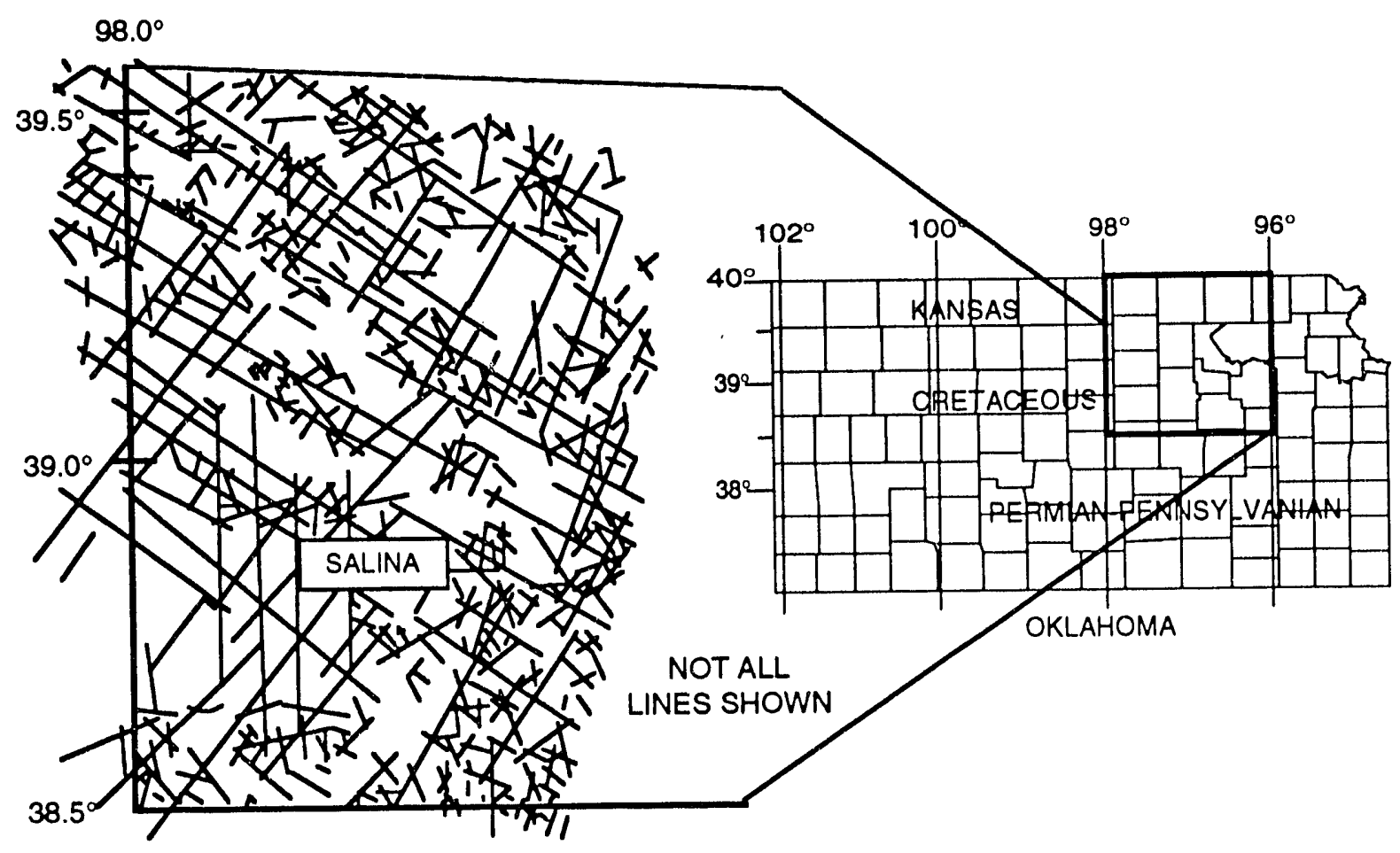

FIGURE 2.53. - Map of Landsat Photolineaments in the Southwestern Corner of the Study Area (from Johnsgard, 1988).

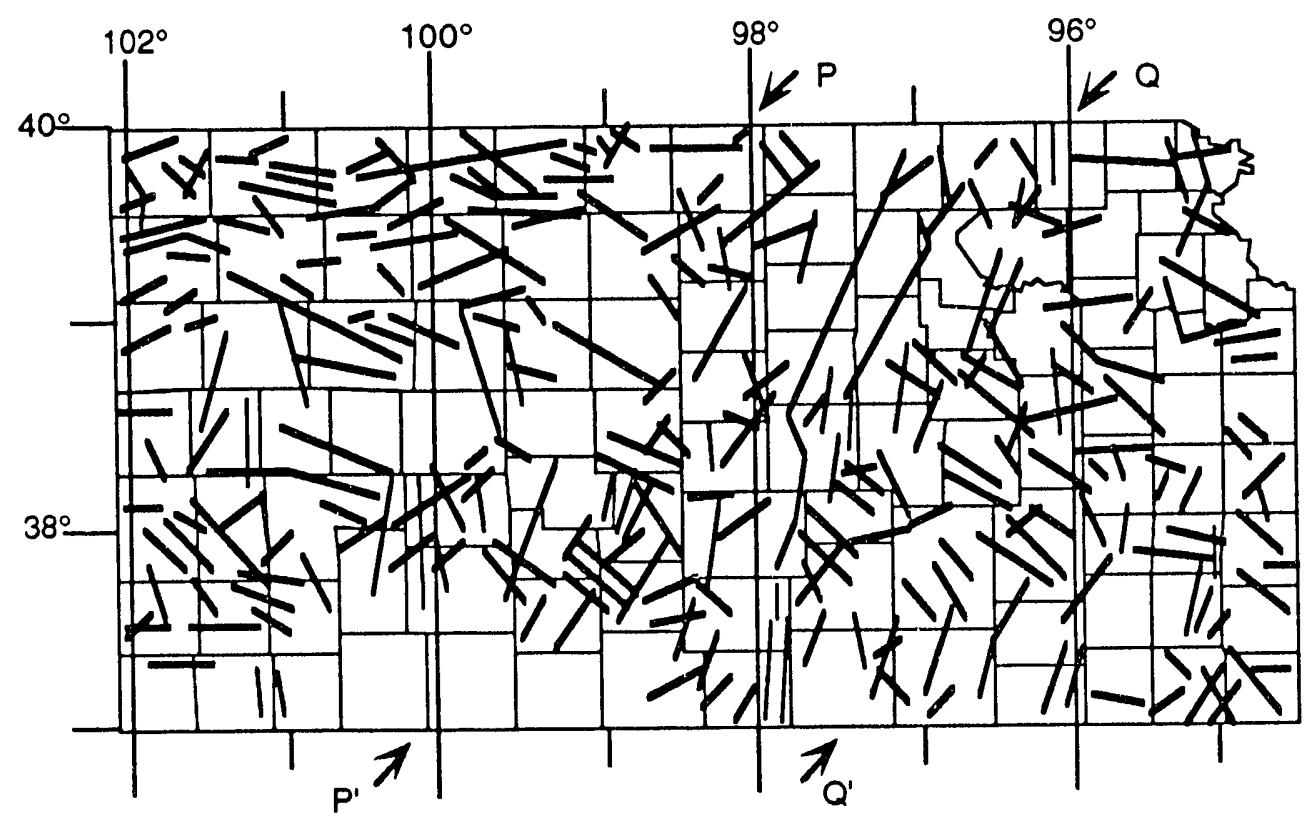

FIGURE 2.54 - Map of Gravity Lineaments in Kansas (from Johnsgard, 1988). 


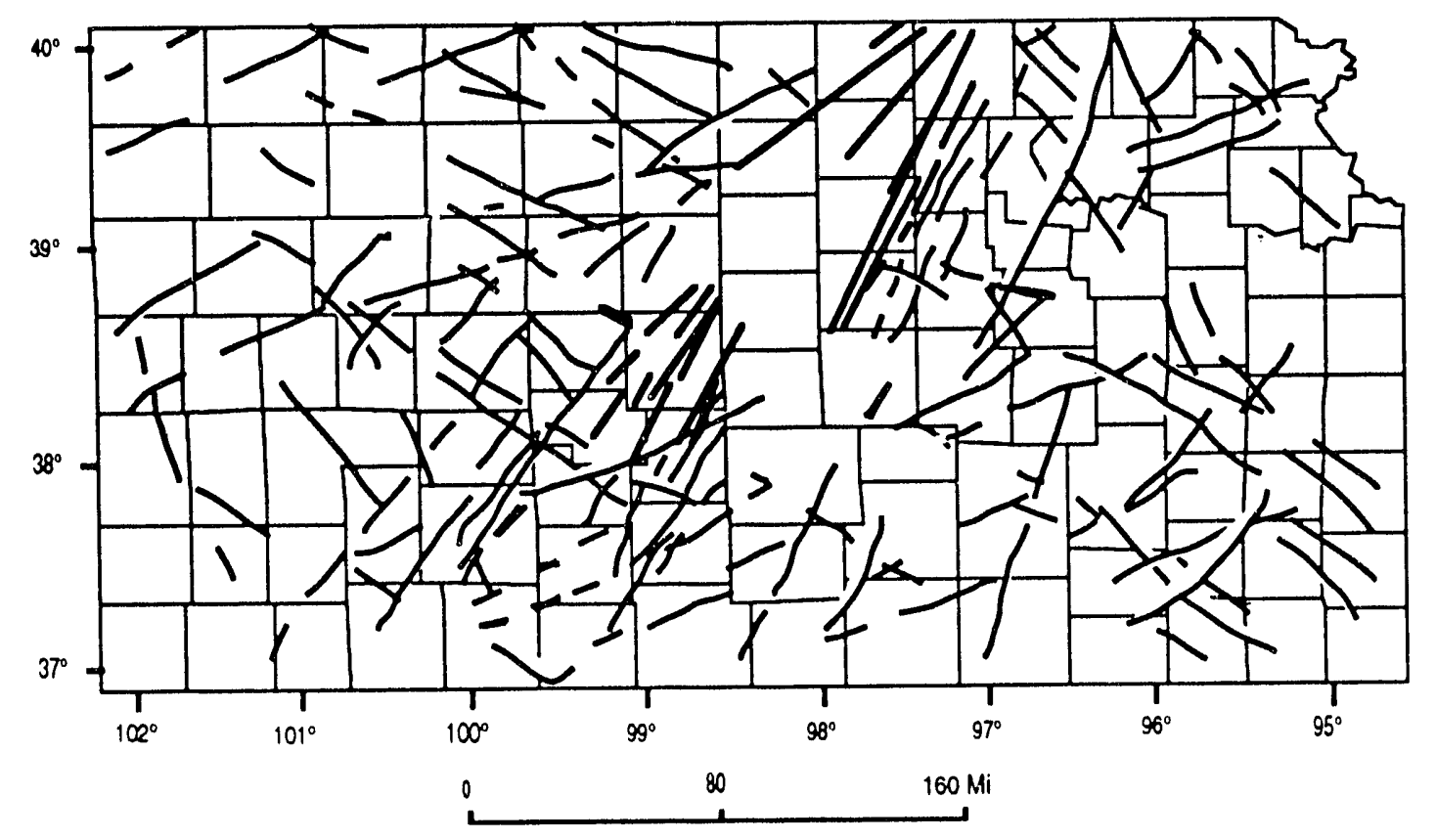

FIGURE 2.55 - Map of Aeromagnetic Lineaments in Kansas (from Johnsgard, 1988).

reservoir to overlying porous and permeable formations and to the surface. Frequently fracturing is recognized in reservoirs by early breakthrough of injected fluids during secondary recovery implementation. No mention has been made in literature reviewed about faulting that may connect subsurface reservoirs to the surface. However, discussion with many previous TEOR operators indicated that when these shallow sandstone reservoirs were repressurized they experienced leaks at old wells, previously abandoned wells, and gases and fluids appeared at the surface where previous manmade disturbances could not be found. These leaks to the surface and to formations overlying the zone where steam or gas were being injected are assumed to be the result of fractures. This poses a potential problem for contamination of shallow aquifers.

\section{HEAVY OIL OCCURRENCE}

Known occurrences of heavy oil production are throughout the state of Kansas. Reservoirs from Cambrian, Reagan Formation, through Upper Pennsylvanian produce heavy oil in Kansas. Many of the known fields that produce heavy oil have sandstones, carbonates, dolomite and/or limestone, as reservoir rock. Sandstones of the Cherokee Group probably contain the largest potential for shallow heavy oil production in Kansas. In the future, Cherokee Group sandstones will probably produce heavy oil through thermal enhanced oil recovery processes as oil prices rise and economics become more favorable. Heavy oil production may never account for a major portion of the oil production from the state of Kansas and in particular from the Cherokee and Forest City Basins. The heavy oil reserves suggested in the discussion of the Cherokee Group 
will probably be found in lenticular sandstone bodies with limited lateral extent containing a few million barrels of recoverable oil reserves each from the good, lower facies described by Bradshaw (1985), Woody (1984), and others.

Resource estimates have been made by several investigators (Table 2.1) for Cherokee Group sandstones in eastern Kansas. These are believed to be high as the definition of heavy oil is undefined. Sandstones of the Cherokee group hold the most potential, as heavy oil reservoir rock at a shallow depth, less than 3,000 feet in the Cherokee and Forest City basins of eastern Kansas. No resource estimate has been made for carbonate reservoir rock in central and western Kansas.

\section{CASE STUDIES OF THERMAL PROJECTS}

Case studies of several thermal enhanced oil recovery projects have been reviewed and analyzed from secondary data. An interpretation of cause(s) for successful or unsuccessful application of successful processes is presented in each case study. Cause(s) for successful or unsuccessful process implementation is (are) based upon review and analysis of these secondary data by the authors. These may not necessarily be the opinion of the company or companies conducting projects reported on from secondary sources.

\section{United States Department of Energy (1978-1981)}

The United States Department of Energy, Bartlesville Energy Technology Center, Bartlesville, Oklahoma conducted a TEOR process field demonstration project using in situ combustion on the Link Lease in Labette County, near Bartlett, Kansas. Prior to implementation of the in situ combustion project, cores of the reservoir were analyzed for reservoir characteristics (Table 2.2). Two attempts to achieve sustained in situ combustion in the Bartlesville sandstone reservoir were made between September 1978 and May 1981 (Miller and Spence 1983). The Bartlesville (Bluejacket) sandstone is a Cherokee Group, Desmoinesian Series, Pennsylvanian Period fluvial-dominated deltaic channel-fill deposit. Cherokee Group sandstones in the Midcontinent area commonly have upper and lower facies. The upper facies presents production problems because of depositional compartmentalization of oil trapped in this facies (Johnson and Olsen, 1991). The first attempt at ignition in September 1978 failed because of compressor failure, air bypass to unplugged wells outside the pattern, and characteristics of the Bartlesville sandstone reservoir. Before a second attempt was made to ignite the reservoir, a lower zone in the reservoir

TABLE 2.1. - Heavy oil resource estimates, Eastern Kansas

\begin{tabular}{lr}
\hline Resource estimate (barrels) & Reference \\
\hline $350,000,000$ (Southeastern Kansas in fielús with light oil production) & Ball, 1965 \\
$200,000,000$ to $225,000,000$ (Cherokee, Crawford, and Bourbon counties) & Ebanks, et al., 1977 \\
\hline
\end{tabular}


TABLE 2.2. - Average reservoir characteristics, United States Department of Energy Link Lease in situ combustion project, Labette County, Kansas (Modified after Miller and Spence, 1983)

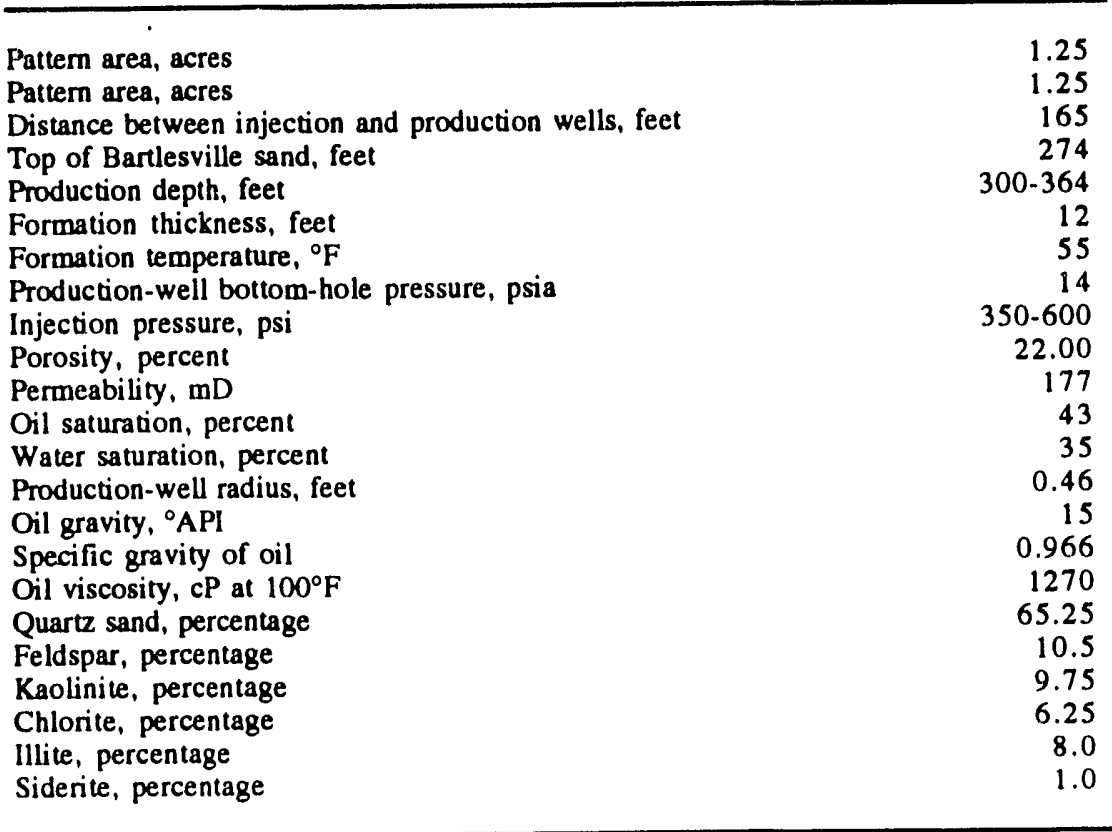

was chosen, and each of the productive wells on the inverted five-spot pattern were stimulated by sand frac. A second attempt at ignition was undertaken in January 1980. During this second attempt, ignition was achieved, but failed to be maintained due to: loss of air to overlying formations that were fractured during well stimulation, bypass of air to unplugged off-pattern wells, compressor failure, direct communication between injector and producer, increased water production after well stimulation, and complexity of the Bartlesville sandstone (Miller and Spence, 1983). The project was terminated due to production problems.

\section{Sun Oil Company, (1965-1968)}

Sun Oil Company conducted a TEOR process field pilot project through implementation of an in situ combustion test in Allen County, Kansas, between April 1965 and June 1968. The Iola Fire Flood Unit was located in southwest Moran Field in the Bartlesville Sandstone reservoir. The first record of oil production in this area was in 1883 (Hardy and Raiford, 1972). The Bartlesville (Bluejacket) sandstone is a Cherokee Group, Desmoinesian Series, Pennsylvanian Period fluvialdominated deltaic channel-fill deposit. Cherokee Group sandstones in the Midcontinent area commonly have upper and lower facies. The upper facies presents production problems because of depositional compartmentalization of oil trapped in this facies (Johnson and Olsen, 1991). The project consisted of two diamond shape patterns with well I-38 as an injection well for a 5-acre pattern and well I-39 as an injection well for a 15-acre pattern. Reservoir characteristics and 
process variables are summarized in Tables 2.3 and 2.4, respectively. The diamond shaped pattern was aligned in a northeast-southwest direction. Southeast and northwest pattern wells were low production wells, with wells on the northeast and southwest as better producers. Hardy and Raiford (1972) concluded that the orientation direction of the pattern was due to anisotropic characteristics of the Bartlesville sandstone reservoir. The primary components, determined by XRay Defraction analysis were quartz and Kaolinite clay (Hardy and Raiford, 1972). The anisotropic characteristics are probably a combination of depositional compartmentalization and natural fracturing in the reservoir. Natural fractures in a northeast-southwest direction occur in the Cherokee and Forest City basins (Johnson and Olsen, 1991). The I-38 injection pattern was implemented on April 9, 1965 and the I-39 pattern on October 1, 1961. The project was concluded in June 1968.

Additional problems occurred with old unplugged wells, poor quality tubingless completions, and produced emulsion. Operating and capital cost of the project were in line with crude oil prices, but Sun moved personnel and equipment to more profitable projects (Hardy and Raiford, 1972). This project did not move to full field implementation of the process.

TABLE 2.3. - Average reservoir characteristics, Sun Oil Company Iola Fireflood Project, Moran Field, Allen County, Kansas (Modified After Hardy and Raiford, 1972)

\begin{tabular}{lr} 
Date of discovery & Before 1920 \\
Formation & Bartlesville \\
Number of injection wells & 2 \\
Number of producing wells & 20 \\
Depth of pay, feet & 830 \\
Gross pay thickness, feet & 35 \\
Average net pay thickness, feet & 17 \\
Acres 1st pattern, I-38 & 5 \\
Acres 2nd pattern, I39 & 15 \\
Average porosity, percent & 21.2 \\
Horizontal permeability, mD & 88.1 \\
Connate water saturation, percent & 21.1 \\
Oil gravity, ${ }^{\circ}$ API & 20.1 \\
Original BHP, psig & 50 \\
Original BHT, oF & 77 \\
Viscosity of oil @ BHT, cP & 750 \\
Saturation GOR, scf/STB & $n i 1$ \\
Formation volume RB/STB & 1.0 \\
Oil content STB/acre-ft (4-9-65) & 1159 \\
Total oil in place, STB (4-9-65) & 788,100 \\
Oil displaced by project, barrels (includes 19,530 consumed in combustion) & 88,238 \\
Oil produced by project, barrels & 61,766 \\
\hline
\end{tabular}


TABLE 2.4. - In situ combustion process variables, Sun Oil Company, Iola Fireflood Project, Moran Field, Allen County, Kansas (Hardy and Raiford, 1972)

\begin{tabular}{lr}
\hline Air requirement scf/cu ft & 310 \\
Fuel consumption, bbVacre-ft & 210 \\
Oxygen utilization, percent & 97 \\
Actual H/C atomic Ratio & 0.85 \\
Apparent H/C atomic ratio & 2.0 \\
Combustion Temperature, ${ }^{\circ} \mathrm{F}$ & 800 \\
\hline
\end{tabular}

Sinclair Research, Inc. (1956-1960)

Sinclair Research, Inc., Tulsa, Oklahoma, conducted a thermal oil recovery test, in situ combustion, on a heavy oil reservoir in Allen County, Kansas. The test was conducted on a 60-acre site in a Bartlesville sandstone reservoir in Humboldt-Chanute Field between 1956 and 1960. Before breakthrough in five producing wells, 79,000 barrels of oil were recovered. There were 20 producing wells and six injection wells in this pilot fireflood project. No detailed description of the Bartlesville sandstone reservoir rock was given except as "a Bartlesville sand 'shoe-string,' typical of a number of small reservoirs in Southeastern Kansas." Since these sandstones were deposited in a fluvial-dominated deltaic environment, it may be concluded, for the Humboldt-Chanute Field heavy oil reservoir, that it is probably highly compartmentalized with numerous bedding-boundary permeability barriers as well as some trough bedded, less compartmentalized sandstone. Average reservoir parameters are listed in Table 2.5.

This pilot is considered to be an unsuccessful implementation of a successful process by the authors of this report. The oil recovered over the 4-year period of the pilot project was about 2.7 BOPD/well, if averaged over the project period. Daily oil production of this amount is marginally higher than present day primary heavy oil production in a similar reservoir in eastern Kansas that was visited during this feasibility study and documented through personal conversations with the field operator (Town, 1990). The $2.7 \mathrm{BOPD} /$ well is above the norm of 0.3 to $0.5 \mathrm{BOPD} /$ well achieved from primary production by several heavy oil producers in the area. Sweep efficiency was reported to be $59 \%$ of the original-oil-in-place for the area swept; however, the area swept by the fireflood project was not defined, unless it was assumed to be the area swept between the injection wells and the breakthrough wells. Oil recovered during the fireflood pilot project represents $11 \%$ of the original oil-in-place on the 60 -acre test site. The project demonstrated that fireflooding a heavy oil reservoir is possible, but more oil production is necessary for the process to be considered successful (economic). Probable cause for poor oil recovery is compartmentalization and diagenetic changes in the reservoir rock, commonly called "heterogeneities." 
TABLE 2.5. - Sinclair Research, Inc. (1956-1960), reservoir characteristics, Humboldt-Chanute Field Fireflood Project, Allen County, Kansas

\begin{tabular}{lr}
\hline & \\
Average depth, ft & 830 \\
Productive area, acres & 68.6 \\
Producing wells & 20 \\
Injection wells & 6 \\
Average sand thickness, ft & 8.8 \\
Maximum sand thickness, ft & 21 \\
Reservoir volume, acre-ft & 604 \\
Porosity, \% & 20.3 \\
Average specific permeability, mD & 85 \\
Reservoir temperature, ${ }^{\circ} \mathrm{F}$ & 78 \\
Gravity of produced crude, ${ }^{\circ}$ API & 23 \\
Oil viscosity at reservoir temperature, cP & 70 \\
Connate-water saturation, \% of pore space & 23 \\
.Estimated formation volume factor & 1.05 \\
Primary production, bbl (9-30-54) & 36,680 \\
Primary production, bbl/acre-ft & 61 \\
Average production during project b/d/well & 2.7 \\
Primary production, \% of original stock-tank oil & 5.3 \\
Estimated original-oil-in-place, bblacre-ft & 1,150 \\
Estimated oil-in-place at start of operation, bbl/acre-ft & 1,089 \\
Sweep efficiency of swept area during project \% OOIP & 59 \\
Oil recovery during project \% OOIP & 11.3 \\
\hline
\end{tabular}

\section{Carmel Energy, Inc. (Vapor Therm Process-1976-1978)}

Carmel Energy, Inc. conducted a pilot test of its patented Vapor Therm Process (Fig. 2.56) during 1976 - 1978 in the Carlyle Pool near Iola, Allen County, Kansas. The Carlyle Pool had produced oil from this reservoir for 50 years before implementation of the cost sharing project. Reservoir characteristics of the Carlyle Pool Vapor Therm pilot project area are summarized in Table 2.6. The project was conducted as a cost-sharing project with the U.S. Department of Energy. Heavy oil was successfully recovered from a Bartlesville sandstone reservoir during the project. A reported total of 9034 barrels of oil was produced by cyclic steam stimulation during four stimulation cycles over an 18 month period. A sustained average rate of $7.8 \mathrm{BOPD} / \mathrm{well}$ and a water/oil ratio of 1:3 were achieved during the project period. During the project period, approximately $6 \%$ (about $71.2 \mathrm{BSTO} / \mathrm{acre}-\mathrm{ft}$ ) of the original-oil-in-place (approximately 1,178 $\mathrm{BSTO} / \mathrm{acre}-\mathrm{ft}$ ) was produced from the project site. Maximum production of 21.6 BOPD/well was achieved during this time.

The Vapor Therm process causes thermal stimulation by injecting flue gas and steam into a reservoir at pressures and temperatures as high as $900 \mathrm{psi}$ and $700^{\circ} \mathrm{F}$ (Fig. 2.56). Steam may be generated by burning diesel, lease crude, natural gas, or other fuel. Wells in the five-spot pattern 


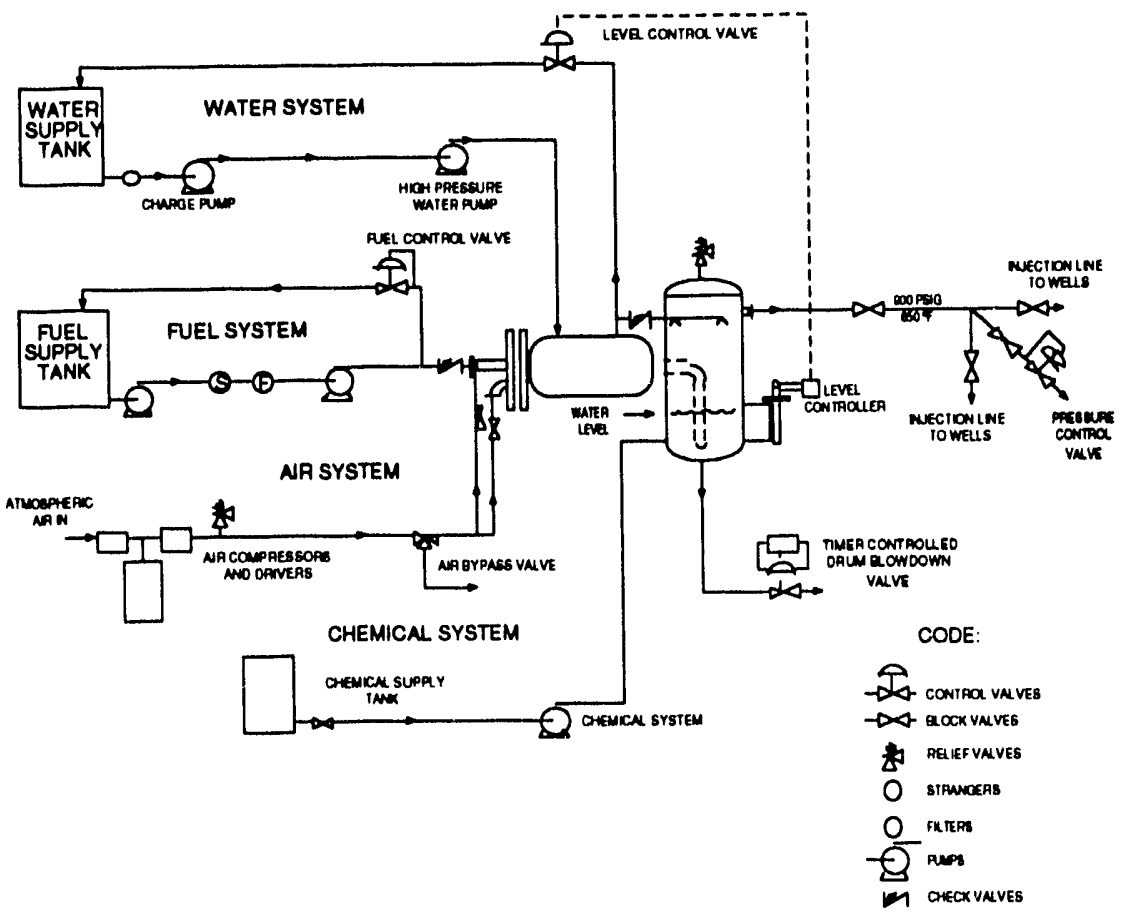

FIGURE 2.56 - Schematic of Vapor-Therm Hardware (from Sperry, et al., 1980).

TABLE 2.6. - Carmel Energy, Inc. (1976-1978), Carlyle Pool, Vapor Therm Cyclic Steam Project, Steam Project, Allen County, Kansas

Average depth, sub-sea ft

Average thickness, $\mathrm{ft}$

Well pattern, -- spot

Producing wells

Well spacing, $\mathrm{ft}$

Average porosity, \%

Average permeability, $\mathrm{mD}$

35

Initial reservoir pressure, $\mathrm{psi}$

5

Oil-in-place prior to project, BSTO/AC-FT

208.7

Oil produced during project, $\mathrm{BO}$

\section{BSTO/AC-FT}

$$
\%
$$

1,127

9,034

71.2

6.04

Oil produced prior to project, \%

Maximum oil production, BSTO/well/week

Max b/d/well

Sustained average oil production rate, b/d/well

Steam injection pressure, psi

Steam injection temperature, ${ }^{\circ} \mathrm{F}$

900

Number of steam cycles

Gravity of oil, ${ }^{\circ} \mathrm{API}$ 
were on an inter-well spacing of $209 \mathrm{ft}$. Oil in the reservoir was $19.5^{\circ}$ API gravity with a viscosity of $1,026 \mathrm{cP}$ at $70^{\circ} \mathrm{F}$. The reservoir sandstone ranged up to $35 \mathrm{ft}$ in thickness with average porosity of $23.6 \%$ and absolute permeability of $695 \mathrm{mD}$. While drilling wells for the fivespot pattern, an estimated 1,197 BSTO/acre-ft in place was calculated for the project area. The heavy oil producing zone overlies an oil/ water contact (aquifer) in the reservoir.

The process is considered to be successful because it recovers incremental oil from reservoirs, but a higher daily volume of oil on a sustained basis would have offered greater incentive for continuing this project beyond the pilot stage. Geological factors probably contributed to low oil recovery during the pilot project. No detailed geological description of the reservoir was given for this project. Therefore, it may be concluded that this Bartlesville sandstone reservoir probably has compartmentalization smaller than the well spacing, small scale bedding boundary permeability barriers, diagenetic changes, and thickness that may have affected daily oil production and recovery during the project period.

\section{Kansas TEOR Projects, 1966 Summary}

Goebel (1966) made a survey of the TEOR projects in progress in Kansas at that time. A summary of Goebel's findings about these projects is summarized in the Table 2.7. When Goebel made the investigation, TEOR was not a proven technology for heavy oil recovery. The TEOR projects that recovered oil in their pilot field tests proved that heavy oil is recoverable from Cherokee Group, fluvial-dominated deltaic sandstones. Since all of these projects were ultimately

TABLE 2.7. - Survey of TEOR Projects in Kansas (Goebel, 1966)

\begin{tabular}{|c|c|c|c|c|c|c|c|c|}
\hline County & Qperater & $\begin{array}{l}\text { Project } \\
\text { orLease }\end{array}$ & Field & Status & Reservoir & $\begin{array}{c}\text { Gravity, } \\
\mathrm{OAD}\end{array}$ & $\begin{array}{c}\text { Depth, } \\
\mathrm{ft}\end{array}$ & $\begin{array}{c}\text { Production, } \\
\text { total bbl }\end{array}$ \\
\hline Allen & Layton- & $\begin{array}{l}\text { Carlyle } \\
\text { Shell }\end{array}$ & Iola & $\begin{array}{l}\text { Active } \\
\text { (fire) }\end{array}$ & B'ville & 20 & 860 & 22,000 \\
\hline Allen & $\begin{array}{l}\text { Great } \\
\text { Western }\end{array}$ & & $\begin{array}{l}\text { H'bolt- } \\
\text { Chanute (196 }\end{array}$ & $\begin{array}{l}\text { Abd } \\
53)\end{array}$ & B'ville & - & 835 & -. \\
\hline Allen & Sinclair & Humboldt & $\begin{array}{l}\text { H'bolt- } \\
\text { Chanute (195 }\end{array}$ & Ab) & B'ville & 23 & 820 & \\
\hline Allen & Sun Oil & Stewart & Moran & $\begin{array}{l}\text { Test } \\
\text { drlg }\end{array}$ & B'ville & 22 & 800 & -- \\
\hline Bourbon & $\begin{array}{l}\text { Standard } \\
\text { Crystals }\end{array}$ & Coonrod & & $\begin{array}{l}\text { Test } \\
\text { prod. }\end{array}$ & B'ville & 21 & 400 & - \\
\hline Crawford & $\begin{array}{l}\text { Gen Oil \& } \\
\text { Gas }\end{array}$ & McCune & $\begin{array}{l}\text { McCune Abd } \\
\text { (1962) }\end{array}$ & B'ville & $-\cdot$ & -- & -- & \\
\hline $\begin{array}{l}\text { Franklin } \\
\text { Labette }\end{array}$ & $\begin{array}{l}\text { CRA, Inc. } \\
\text { Collins }\end{array}$ & $\begin{array}{l}\text { Broers } \\
\text { Bartlett }\end{array}$ & Baldwin & $\begin{array}{l}\text { Active } \\
\text { Test }\end{array}$ & $\begin{array}{l}\text { Squirrel } \\
\text { B'ville }\end{array}$ & $\begin{array}{r}24 \\
14-17\end{array}$ & $\begin{array}{l}760 \\
270\end{array}$ & $\begin{array}{l}-- \\
--\end{array}$ \\
\hline Montgomery & Sage & Coffrille & & & B'ville & 24 & 1.200 & \\
\hline Wilson & Johnson & $\begin{array}{l}\text { Roper } \\
\text { \& Wood }\end{array}$ & $\begin{array}{l}\text { Buffalo- } \\
\text { Vilas }\end{array}$ & $\begin{array}{l}\text { Active } \\
\text { steam }\end{array}$ & B'ville & 21 & 1,000 & 750 \\
\hline
\end{tabular}


abandoned, several different conclusions may be made concerning causes for discontinuation of projects. The authors have concluded that low oil recovery on a per well basis was probably caused by geologic reasons as stated above, rather than by application of an ineffective recovery method. Probable cause for abandonment: technical success but economic failure due to geologic conditions causing low oil recovery.

\section{BIBLIOGRAPHY}

Abandoned Oil Fields in Kansas and Nebraska, Dec. 1982. U. S. Dept. of Energy, Report No. DOE/BETC/IC-82/3. 1982.

Abernathy, G. E., J. M. Jewett and W. H. Schoewe. Coal Reserves in Kansas. Kansas Geological Survey, 1947.

Aden, L. J. Clay Mineralogy and Depositional Environments of Upper Cherokee (Desmoinesian) Mudrocks, Eastern Kansas, Western Missouri, and Northeastern Oklahoma [MS Thesis]. University of Iowa, 1982.

Adams, W. L. Diagenetic Aspects of Lower Morrowan, Pennsylvanian Sandstones, Northwest Oklahoma AAPG, v. 48, 1964, p.1568-1580. Bulletin.

Adler, F. J. Future Petroleum Provinces of the Midcontinent, Region 7 AAPG, 1971, pp. 9851120. (Cram IH, ed. Future Petroleum Provinces of the United States- Their Geology and Potential; v Memoir 15).

Baars, D. L., W. L. Watney, D. W. Steeples and E. A. Brostuen. Petroleum: A Primer for Kansas. Lawrence, Kansas: Kansas Geological Survey, v. 7, 1989, p. 40. Educational Series.

Ball, S. M. Stratigraphy of the Douglas Group (Pennsylvanian, Virgilian) in the Northern Midcontinent Region [PhD Dissertation]. University of Kansas, 1964.

Ball, S. M. Prediction of Effective Porosity in Some Marine Oolite Deposits. Kansas Geological Survey, 1966.

Bass, N. W. Origin of the Shoestring Sands of Greenwood and Butler Counties, Kansas. AAPG Bulletin v. 18, 1934, pp. 1313-1345.

Beene, D. L. 1976 Oil and Gas Production in Kansas. Lawrence, Kansas: Kansas Geological Survey, v. 10, 1977, p. 169. Energy Resources Series.

Beene, D. L. 1988 Oil and Gas Production in Kansas. Kansas Geological Survey, 1989.

Bradshaw, D. T. Geologic Variables Influencing Production in Eastburn Field, Vernon County, Missouri [MS Thesis]. Colorado State University, 1985.

Brenner, R. L. Stratigraphy, Petrology and Paleogeography of the Upper Portion of the Cherokee Group (Middle Pennsylvanian), Eastern Kansas and Northeastern Oklahoma. Lawrence, Kansas. Kansas Geological Survey, 1989 Geology Series 3. 
Brown, H. A. Examination of Pennsylvanian Carbonate Banks in Southwestern Kansas. Lawrence, Kansas: Kansas Geological Survey, 1963.

Busch, D. A. Prospecting for Stratigraphic Traps. AAPG Bulletin, v. 43, 1959, pp. 2829-2843.

Caldwell, C. D and R. Boeken. Wireline Log Zones and Core Description of Upper Part of the Middle Ordovician Viola Limestone, McClain and McClain Southwest Fields, Nemaha County, Lawrence, Kansas: Kansas Geological Survey, 1985, pp. 17-35. (Watney, W.L., Doveton, J.H., Walton, A.W., ed. Core Studies in Kansas; Sedimentology and Diagenesis of Economically Important Rock Strata in Kansas; vol Subsurface Geology Series 6).

Cole, V. B. Subsurface Ordovician-Cambrian Rocks in Kansas. (Reprinted 1981 ed.) Lawrence, Kansas: Kansas Geological Survey, v. 2, 1975, Subsurface Geology Series.

Cole, V. B. Thickness of Formations Within the Mississippian in Southwestern Kansas. Lawrence, Kansas: Kansas Geological Survey, v. 2, 1975 Subsurface Geology Series. Reprinted 1981.

Daniels, R. P. Pennsylvanian (Desmoinesian) Stratigraphy and Petroleum Potential, Southeast Colorado [MS Thesis]. Colorado School of Mines, 1985.

Denesen, S. L. Stratigraphy, Petrography, and Depositional Environments of the Banzet Formation (Middle Pennsylvanian) in Southeastern Kansas and Northeastern Oklahoma IMS Thesis]. University of Iowa, 1985.

Development and Field Testing of a Process for Recovering Heavy Crude Oil in the Carlyle Pool Allen County, Kansas using the Vapor Therm Generator-Final Report. Dept. of Energy, 1980.

Dowd, W. T., V. A. Kuuskraa and M. L. Godec. A Technical and Economic Assessment of Domestic Heavy Oil. U.S. Department of Energy, Report No. DOE/BC/10840-1, 1988.

Ebanks, W. J.and G. W. James. Heavy-crude Bearing Sandstones of the Cherokee Group (Desmoiniesian) in Southeastern Kansas. Oil Sands Fuel of the Future. Lawrence, Kansas: Kansas Geological Survey, 1975, pp. 19-34.

Ebanks, W. J. Kansas Oil for Enhanced Recovery-A Resource Appraisal. Kansas Geological Survey, 1976.

Ebanks, W. J., G. W. James and N. D. Livingston. Evaluation of Heavy Oil and Tar Sands in Bourbon, Crawford, and Cherokee Counties, Kansas. U. S. Department of Energy, Report No. Berc/RI-77/20, 1977.

Ebanks, W. J., Jr. Geology in the Enhanced Recovery of Oil. Proceedings of the Second Tertiary Oil Recovery Conference. Wichita, Kansas. April 20, 21, 1977. Tertiary Oil Recovery Project, Institute of Mineral Resources Research, University of Kansas, Lawrence, Kansas, 1977.

Ebanks, W. J. Jr., L. L. Brady, P. H. Heckel, H. G. O'Connor, G. A. Sanderson, R. R. West, and F. W. Wilson The Mississippian and Pennsylvanian (Carboniferous) Systems in the United States--Kansas. Kansas Geological Survey, Geological Survey Professional Paper 1110-Q, 1979. 
Ece, O. I. Depositional Environment, Stratigraphy, Petrology, Paleogeography, and Organic Thermal Maturation of the Desmoinesian Cyclothermic Excello Black Shale in Oklahoma, Kansas, and Missoui i [PhD Dissertation], University of Tulsa, 1985.

Emery, L. W. Results From a Multi-Well Thermal-Recovery Test in Southeastern Kansas. J. Petrol. Tech., v. 14, No. 6, June 1962, pp. 671-678.

Franz, R. H. Lithofacies, Diagenesis, and Petrophysical Properties of Selected Sandstone from the Morrowan Kearny Formation of Southwestern Kansas [MS Thesis]. University of Kansas, 1983.

French, J. A. and W. L. Watney. Computer Modeling of Midcontinent Cyclotherms: Application to the Prediction of Hydrocarbon Reservoirs. Annual Meeting of AAPG-SEPM, June 1990. San Francisco, CA, 1990.

Goebel, E. D. Stratigraphy of Mississippian Rocks in W'vstern Kansas [PhD Dissertation]. University of Kansas, 1966.

Goebel, E. D. Thermal Recovery Projects Are Increasing in Kansas, Missouri. World Oil 1966; 162(4; pp. 78-80.

Goebel E. D. Cambrian System, Lawrence, Kansas: Kansas Geolcgical Survey, 1968, pp. 11 14. (Zeller DE, ed. The Stratigraphic Succession in Kansas; Bulletin 189).

Goebel, E. D. Ordovician System, Lawrence, Kansas: Y.ansas Geological Survey, 1968, pp. 1415. (Zeller DE, ed. The Stratigraphic Succession in Kansas; Bulletin 189).

Goebel, E. D. Mississippian System, Lawrence, Kansas: Kansas Geological Survey, 1968, pp. 17-21. (Zeller DE, ed. The Stratigraphic Succession in Kansas; Bulletin 189).

Goebel, E. D. Mississippian Rocks of Western Kansas, AAPG. Bulletin, v. 52, 1968, pp. 17321778.

Goebel, E. D. and G. F. Stewart. Paleotectonic Investigations of the Mississippian System in the United States. Kansas Geological Survey, 1973.

Gould, G. F. Maturation and Alteration of Crude Oils in the Cherokee Group (Middle Pennsylvanian) of Southeastern Kansas [MS Thesis]. University of Kansas, 1975.

Hardy, W. I.and J. D. Raiford. In Situ Combustion in a Bartlesville Sand - Allen County, Kansas. Sun Oil Company, 1972.

Hardy, W. C.and J. D. Raiford. High Recovery in Old Sand Boots Fire Flood Optimism. World Oil, 1976, January 1976, pp. 80-85.

Harris, J. W. Stratigraphy and Depositional Environments of the Krebs Formation - Lower Cherokee Group (Middle Pennsylvanian) in Southeastern Kansas [MS Thesis]. University of Kansas, 1984.

Harris, J. W. Stratigraphy of the Cherokee Group, Southeastern Kansas, Lawrence, Kansas: Kansas Geological Survey, 1985, pp. 66-73. (Watney W. L., J. H. Doveton, A. W. Walton, ed. Core Studies in Kansas; Sedimentology and Diagenesis of Economically Important Rock Strata in Kansas; Subsurface Geology, Series 6). 
Hatch, J. R., J. D. King and T. A. Daws. Geochemistry of Cherokee Group Oils of Southeastern Kansas and northeastern Oklahoma[sic].Lawrence, Kansas. U.S. Geological Survey, 1989, Subsurface Geology Series; v. 11.

Haworth, E. Special Report on Oil and Gas. University Geological Survey of Kansas, v. 9, 1908.

Hudson, A. S. Depositional Environment of the Red Fork and Equivalent Sandstones East of the Nemaha Ridge Kansas and Oklahoma [MS Thesis]. University of Tulsa, 1969.

Hulse, W. J. Depositional Environment of the Bartlesville Sandstone in the Sallyards Field, Greenwood County, Kansas. Tulsa, Oklahoma: Tulsa Geological Society, 1979, pp. 327336. (Hyne, N.J., ed. Pennsylvanian Sandstones of the Midcontinent; Special Publication No. 1).

Ireland, H. A. Regional Depositional Basin and Correlation of the Simpson Group. Tulsa, Oklahoma: Tulsa Geological Society, v. 12, 1965, pp. 215-234. Tulsa Geological Society Digest.

Jewett, J. M. Geologic Structures in Kansas. Lawrence, Kansas: Kansas Geological Survey, Bulletin v. 90, pt. 6, 1951, pp. 105-172.

Jewett, J. M. Oil and Gas in Eastern Kansas. Lawrence: Kansas Geological Survey, Bulletin 104, 1954, Reprint 1981.

Jewett, J. M. and D. F. Merriam. Geologic Framework of Kansas-A Review for Geophysicists. Lawrence, Kansas: Kansas Geological Survey, v. 137, 1959, pp. 9-52. (Hambleton, W.W., ed. Symposium on Geophysics in Kansas Bulletin.

Johnsgard, S. K. The Fracture Pattern of North-central Kansas and Its Relation to Hydrogen Soil Gas Anomalies Over the Midcontinent Rift System [MS Thesis]. University of Kansas, 1988.

Johnson, W. I. and D. K. Olsen. Midcontinent Fluvial Depositional Environments and Their Influence on Enhanced Oil Recovery. Pres. at Petroleum-Reservoir Geology in the Southern Midcontinent Workshop, Univ. of Oklahoma, Mar. 26-27, 1991.

Kansas Oil and Gas Fields. (1st ed.) Lawrence, Kansas: Kansas Geological Survey, v. 5,1985, p. 326.

Kansas Oil and Gas Fields, Northeast Kansas, Lawrence, Kansas: Kansas Geological Survey, v. 3, 1960, p. 220.

Kansas Oil and Gas Fields. (1st ed.) Lawrence, Kansas: Kansas Geological Survey, v. 4,1965, p. 307.

Kansas Geological Survey Bulletin, 1968. Kansas Geological Survey, 1968.

Kansas Geological Survey. Kansas Oil and Gas Pools.Lawrence, Kansas: Kansas Geological Survey, v. 1, 1956, p. 95.

Kansas Geological Survey. Kansas Oil and Gas Fields.Lawrence, Kansas: Kansas Geological Survey, v. 3, 1960, p. 219. (Curtis, G.R., ed.). 
Kansas Geological Survey. Lineament Map of the Nemaha Uplift Region. Lawrence, Kansas. Kansas Geological Survey, 1982.

Khaiwka, M. H. Geometry and Depositional Environment of Morrow Reservoir Sandstones, Northwestern Oklahoma. Shale Shaker, v. 23, 1973, pp. 196-214.

Knight, K. L. Stratigraphy, Depositional and Diagenetic History of Three Middle Pennsylvanian Cyclotherms (Breezy Hill and Fort Scott Limestones), Midcontinent North America [PhD Dissertation]. University of Iowa, 1985.

Lardner, J. E. Petrology, Depositional Environment, and Diagenesis of Middle Pennsylvanian (Desmoinesian) 'Lagonda 'nterval' Cherokee Group in East-central Kansas [MS Thesis]. University of Iowa, 1984.

Larsh, H. A., ed. Kansas Oil and Gas Fields- Western Kansas. Lawrence, KS: Kansas Geological Society, v. II, 1959, p. 197.

Little, A. D. Strategic Analysis of the Oil and Gas Industry in Kansas. Kansas Inc., 1989.

Little, A. D. Strategic Analysis of the Oil and Gas Industry in Kansas. Kansas Inc., 1990.

Mahony, B. J. Thermal Recovery Projects Spark Kansas Lease Play. World Oil, 1964, September 1964, pp. 110-114.

McElroy, M. N. Lithologic and Stratigraphic Relationships Between the Reagan Sandstone (Upper-cambrian) and Sub-reagan and Supra-reagan Rocks in Western Kansas [PhD Dissertation]. University of Kansas, 1965.

McKown, K. W., P. O. Scheuerman, B. A. Matthews and M.L. Lowmaster. Enhanced Oil Recovery in the Cattleman Sandstone. Proceedings of the Eighth Tertiary Oil Recovery Conference. Wichita, Kansas, Mar. 8-9, 1989. Tertiary Oil Recovery Project, University of Kansas, Lawrence, Kansas, 1989.

McLaughlin, J. E. Annotated Bibliography of the Anadarko Basin Area Kansas-OklahomaTexas,.v. GILD 007, 1984.

McLaughlin, J. E. Supplement to Annotated Bibliography of the Anadarko Basin Area KansasOklahoma-Texas, v. GILD 007,.1985.

McManus, D. A. Stratigraphy and Depositional History of the Kearny Formation (Lower Pennsylvanian) in Western Kansas [PhD Dissertation]. University of Kansas, 1959.

Merriam, D. F. and T. E. Kelly. Preliminary Regional Structural Contour Map of Top of "Hunton" (Silurian-Devonian) Rocks in Kansas, 1st ed, Lawrence, Kansas: Kansas Geological Survey, 1960.

Merriam, D. F. The Geological History of Kansas, 4th ed., Lawrence, Kansas: University of Kansas Publications, 1963. (Cristensen, N. P., ed.; Bulletin 162).

Miller, J. S.personal communication, February 1986.

Miller, J. S. and K. L. Spence. In Situ Combustion Project at Bartlett, Kansas. U.S. Dept. of Energy, Report No. DOE/BETC/RI-83/3, 1983. 
Mitchell, J. C. Stratigraphy and Depositional History of the Iola Limestone Upper Pennsylvanian (Missourian), Northern Midcontinent U. S. [PhD Dissertation]. University of Iowa, 1981.

Moore, R. C. and J. M. Jewett. Oil and Gas Fields of Kansas. Mines Magazine, 1942, v.32, pp. 481-488,515-520,526,538,560.

Nelson, M. R. Petrology, Diagenesis and Depositional Environment of the Lagonda Interval, Cabaniss Subgroup, Cherokee Group, Middle Pennsylvanian, in North-eastern Kansas [MS Thesis]. Iowa, 1985.

Newell, K. D; W. L. Watney and J. R. Hatch. Time-temperature Estimates of Thermal Maturation in North-central and Northeast Kansas.Geological Society of America, Abstracts with Programs, South-central Section, v. 17, 1985, pp. 185-186.

Newell, D. K., W. L. Watney, S. W. L. Cheng and R. L. Brownrigg. Stratigraphic and Spatial Distribution of Oil and Gas Production in Kansas.Lawrence, Kansas, Kansas Geological Survey, 1987. Subsurface Geology Series, v. 9.

Ockerman, J. W. Asphalt Rocks in Eastern Kansas. In: State Geological Survey of Kansas, 1932.

Oil and Gas Production in Kansas, Oil and Gas Data Set 88. Kansas Geological Survey, 1988.

Olsen, D. K. and W. I. Johnson. Feasibility Study of Heavy Oil Recovery in the Midcontinent Region. Presented. at Petroleum-Reservoir Geology in the Southern Midcontinent Workshop, Univ. of Oklahoma, Mar. 26-27, 1991.

Owen E. W. Trek of the Oil Finders: A History of Exploration for Petroleum.Tulsa, Ok.: AAPG, Memoir 6, v. 1, 1975.

Oros, M., D. Saile and R. Sherman. Enhanced Oil-Recovery Operations in Kansas. .Lawrence, Kansas: Kansas Geological Survey, Energy Resources Series, v. 11, 1977, p. 108.

Paul, S. E. and E. L. Bahnmaier. Enhanced Oil-Recovery Operation in Kansas 1978.Lawrence, Kansas: Kansas Geological Survey, Energy Resource Series, v. 15, 1980 , p. 211.

Paul, S. E. and E. L. Bahnmaier. Enhanced Oil-Recovery Operations in Kansas 1980.Lawrence, Kansas: Kansas Geological Survey, Energy Resources Series, v. 19, 1981 , p. 242.

Paul, S. E. and E. L. Bahnmaier. Enhanced Oil-Recovery Operations in Kansas 1979.Lawrence, Kansas: Kansas Geological Survey, Energy Resources Series, v. 17, 1981, p. 211.

Paul, S. E.and D. L. Beene. 1982 Oil and Gas Production in Kansas.Lawrence, Kansas: Kansas Geological Survey, Energy Resources Series, v. 23, 1983, p. 217.

Paul, S.E.and D. L. Beene. 1983 Oil and Gas Production in Kansas.Lawrence, Kansas: Kansas Geological Survey, Energy Resource Series, v. 24, 1985, p. 230.

Powell, J. P.and J. L. Eakin. Waterflooding in the Oil Fields of Anderson, Franklin, Linn, and Miami Counties, Kansas;.Oak Ridge, Tennessee: USDOE Office of Scientific and Technical Information, Report of Investigations; v. 4991, 1953, p. 111. 
Powell, J. P. Survey of Water-flooding Projects in Allen, Bourbon, Crawford, Labette, and Neosho Counties, Kans.Oak Ridge, Tennessee: USDOE Office of Scientific and Technical Information, Report of Investigations; v. 5317, 1957, p. 172.

Roscoe, B. Jr. and F. J. Adler. Permo-Carboniferous Hydrocarbon Accumulations, Midcontinent, U. S. A.AAPG, Bulletin, v. 67, 1983, pp. 979-1001.

Reinholtz, P. N. Distribution, Petrology and Depositional Environment of "Bush City Sandstone" and "Centerville Lagonda Sandstone" in Cherokee Group (Middle Pennsylvanian), Southeastern Kansas [MS Thesis]. University of Iowa, 1982.

Rich, J. L. Shoestring Sands of Eastern Kansas. AAPG Bulletin, v. 7, 1923, pp. 103-113.

Rich, J. L. Further Observation on Shoestring Oil Pools of Eastern Kansas. AAPG Bulletin, v. 10,1926, pp. 568-580.

Rofheart, D.H. Depositional Environment, Diagenesis and Petrophysical Properties of the Upper Bluejacket Sandstone (Desmoinesian), KB Field, Allen County, Kansas [MS Thesis]. Kansas, 1986.

Saile D. K. and M. Ol Oros. Enhanced Oil-Recovery Operations in Kansas, 1975. .Lawrence, Kansas: Kansas Geological Survey, Energy Resource Series, v. 7, 1976, p. 112.

Shields, D. C. Depositional Environment of an Upper Pennsylvanian (Virgilian: Wabaunsee Group) Cyclic Sequence in Nebraska and Kansas [MS Thesis]. University of Nebraska, 1987.

Sorensen, J. H., S. J. Johngard and C. Wozencraft. Bibliography of Kansas Geology, 18231984,.Lawrence, Kansas: Kansas Geological Survey, 1989, p. 418.

Sperry, J. S., F. S. Young and R. S. Poston. Development and Field Testing of a Process for Recovering Heavy Crude Oil in the Carlyle Pool-Allen County, Kansas Using the Vapor Therm Generator. Carmel Energy, Inc., U. S. Department of Energy Report No. DOE/BETC-2880-1, 1980.

St. Clair, P. N. Depositional History and Diagenesis of the Viola Limestone in South-central Kansas [MS Thesis]. University of Kansas, 1982.

Staton, M. D. Stratigraphy and Depositional Environments of the Cherokee Group (Middle Pennsylvanian), Central Cherokee Basin, Southeastern Kansas [MS Thesis]. Kansas, 1987.

Stavnes, S. A. A Preliminary Study of the Subsurface Temperature Distribution in Kansas and Its Relationship to the Geology [MS Thesis]. University of Kansas, 1982.

Stewart, G. F. Paleotectonic Investigation of the Pennsylvanian System in the United States. Lawrence, Kansas: Kansas Geological Survey, 1971

Structural Contour Map Base of Kansas City Group or Older Pennsylvanian Rock Units of the Nemaha Uplift Region. U. S. Geological Survey, 1982.

Survey of Water-flooding Projects in Allen, Bourbon, Crawford, Labette, and Neosho Counties, Kansas, April 1957. U.S. Bureau of Mines, Report No. 5317, 1957. 
Swanson, D. C. Deltaic Deposits in the Pennsylvanian Upper Morrow Formation of the Anadarko Basin. (Special Publication No. 1 ed.) Tulsa, Oklahoma: Tulsa Geological Society, 1979, p. 115-168. (Hyne NJ, ed. Pennsylvanian Sandstones of the Midcontinent.)

Taylor, H. Middle Ordovician Limestone in Central Kansas.AAPG, Bulletin, v. 31, 1947, pp. 1242-1282.

Terwilliger-Robertson, S. J. Petrology and Depositional Sequences of the Council Grove Group (Lower Permian) Panoma Field, Grant and Haskell Counties, Kansas [MS Thesis]. Tulsa University, 1983.

Thomas, M. A. Petrology and Diagenesis of the Lower Mississipp an, Osagean Series, Western Sedgwick Basin, Kansas [MS Thesis]. University of Missouri-Columbia, 1982.

Twell, C. F. Relation of Petroleum Accumulation to Clay Minerals in Some Lansing and Kansas City Group (Pennsylvanian) Cores of Western Kansas [MS Thesis]. Kansas State University, 1964.

Van Dyke, R. J. Geology and Depositional Environments of the Reservoir Sandstone, Kincaid Oil Field, Anderson County, Kansas [MS Thesis]. Kansas University, 1975.

Taylor, H. Middle Ordovician Limestone in Central Kansas.AAPG, Bulletin, v. 31, 1947, pp. $1242-1282$.

Walters, R. F. Oil Production from Fractured Precambrian Basement Rocks in Central Kansas. AAPG, 1953.

Walton, A. W., D. J. Bouquet, R. A. Evenson, D. H. Rofheart and M. D. Woody. Characterization of Sandstone Reservoirs in the Cherokee Group (Pennsylvanian, Desmoinesian) of Southeastern Kansas. University of Kansas, 1986.

Waterflooding in the Oil Fields of Anderson, Franklin, Linn, and Miami Counties, Kansas, June 1953. U. S. Bureau of Mines, Report No. 4991, 1953.

Watney, W. L. Cyclic Sedimentation of the Lansing-Kansas City Groups in Northwestern Kansas and Southwestern Nebraska.Lawrence, Kansas: University of Kansas Publications, 1980, p. 72.

Watney, W. L. Exploration for Petroleum in Cyclic Sediments of Late Pennsylvanian Age in Central and Western Kansas-A Closer Look at a Mature Province. In: Kansas Geological Survey, 1981.

Watney, W. L. Recognition of Favorable Reservoir Trends in Upper Pennsylvanian Cyclic Carbonates in Western Kansas.Tulsa, Oklahoma: Tulsa Geological Society, 1984, pp.201246. (Hyne NJ, ed. Limestones of the Midcontinent; Special Publication No. 2.)

Watney, W. L., A. W. Walton and J. H. Doveton. Core Studies in Kansas.Lawrence, Kansas: Kansas Geological Survey, Subsurface Geology Series, v. 6, 1985, p. 172. (AdkinsHeljeson MD, ed.)

Watney, W. L. Origin of Four Upper Pennsylvanian (Missourian) Cyclotherms in the Subsurface of Western Kansas Application to Search for Accumulation of Petroleum [PhD Dissertation]. Kansas University, 1985. 
Watney, W. L., A. W. Walton and J. H. Doveton, ed. Core Studies in Kansas. Sedimentology and Diagenesis of Economically Important Rock Strata in Kansas. Lawrence, Kansas. Kansas Geological Survey, Subsurface Geology Series 6, v. 6, 1985, p. 171.

Watney, W. L. Petroleum Reservoir Characterization of Upper Pennsylvanian Cyclic Carbonates in the Hugoton Embayment. Lawrence, Kansas: Panhandle Geological Society, 1986.

Watney, W. L. Depositional Sequence Analysis and Sedimentologic Modeling for Improved Prediction of Pennsylvanian Reservoirs. In: Kansas Geological Survey, 1990.

Wells, J. S. and K. H. Anderson. Heavy Oil in Western Missouri. The American Association of Petroleum Geologists, Bulletin 52, 1968, September 1968, pp. 1720-1731.

Wells, J. S. Inventory of Heavy Oil in Western Missouri. U. S. Department. of Energy, Report No. BETC-1808-1, 1979.

Woody, M. D. Sedimentology, Diagenesis, and Petrophysics of Selected Cherokee Group (Desmoinesian) Sandstones in Northeastern Kansas [MS Thesis]. University of Kansas, 1984.

Worthington, R. E. Petrology of the Middle Pennsylvanian (Desmoinesian) "Upper Bluejacket" Sandstone (Cherokee Group) of Bourbon, Crawford, and Cherokee Counties, Kansas [MS Thesis]. University of Iowa, 1982.

Zeller, D. E., ed. The Stratigraphic Succession in Kansas, 4th ed. Lawrence, Kansas: University of Kansas Publications, v. 189, 1986, p. 81. (Adkins-Heljeson MD, ed.) 


\section{CHAPTER 3}

\section{HEAVY OIL OCCURRENCE AND INTEGRATED ANALYSES OF GEOLOGY AND ENHANCED OIL RECOVERY PROCESS APPLICATIONS IN MISSOURI}

\section{SUMMARY}

Heavy oil is found in shallow, low-permeability $(<500 \mathrm{mD})$, consolidated sandstone formations in the Missouri counties that border Kansas. These sandstones were deposited as meandering stream channels and occur as narrow elongated fields. Reservoir rock is cemented, highly compartmentalized, with complex internal architecture, it is fractured and has experienced extensive diagenesis. Fracture alignment is generally in a northeast-southwest direction with perpendicular secondary fractures. Surface fractures are an excellent indication that reservoir rock and confining beds are also fractured. Small volumes of heavy oil ( $<0.3 \mathrm{BOPD})$ are obtained by primary production. TEOR methods (steam, steamflooding, steam and combustion gas, and fireflooding) have proven that the oil can be recovered using close spaced wells (often $<150 \mathrm{ft}$ ). However, none of the projects reported appear both economic and environmentally acceptable.

\section{BACKGROUND}

In the late 1860 s, after the Civil War, oil and gas were produced from wells near Kansas City. By 1967, oil was being produced from 146 wells in 6 counties including Atchison, Cass, Jackson, Platte, St. Louis, and Vernon while Caldwell and Clinton Counties were producing gas from 26 wells. Heavy oil impregnated sandstone has been mined from open quarries by several operators, with Bar-Co-Roc, Incorp. (1920s to 1960s) probably being the most successful. In the 1950s Phillips Petroleum Company, near Bellamy, Missouri, and Carter Oil Company, in Vernon County, Missouri, conducted thermal oil recovery pilot projects in shallow heavy oil channel-fill sands of the Cherokee Group, Pennsylvanian Period. Shell Oil Company later, in the 1960s, conducted a thermal oil recovery pilot project in Vernon County, Missouri, but released very little information. Several companies produced heavy oil using various thermal processes during the 1970s and 1980s. Total cumulative oil production for Missouri from the outset of maintaining state production records in 1966 to the end of 1988 is 715,000 barrels. Carmel Energy, Incorporated produced over 550,000 barrels of this oil from the Eastburn Field, Vernon County, Missouri, by applying their patented Vapor Therm (steam and flue gas) process.

Gas was being used for heating in western Missouri as early as 1909. Gas has been produced from reservoirs in channel-fill sandstones, shale, and coal seams of Upper Cherokee, Marmaton, Pleasanton, and lower Kansas City Groups, Pennsylvanian System (Fig. 3.1). Heavy oil that is difficult or impossible to produce by conventional methods is associated with gas in 


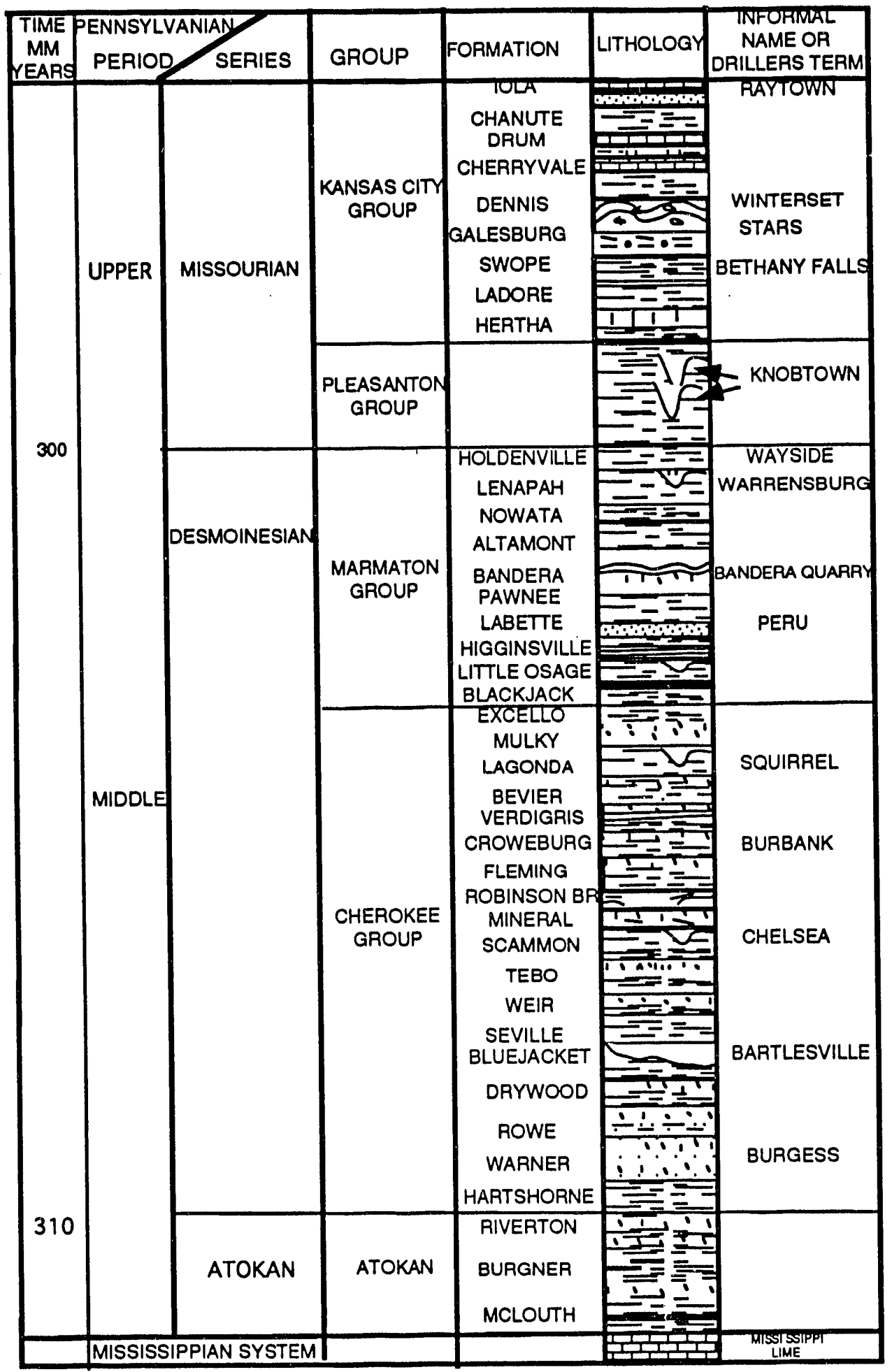

FIGURE 3.1. - Generalized Columnar Section of Pennsylvanian Strata for Western and Northwestern Missouri. Informal and Driller's Terms are to the Right of the Column (from Wells and Anderson, 1968). 
some of these channel-fill sandstone reservoirs. Small operators realized by the 1920 s, that heavy oil associated with gas production was difficult to produce and attempts to do so were abandoned. Sandstones that are reservoir rock for these gas reservoirs were deposited fluvial-dominated deltaic systems. The discontinuous channel-fill sandstone reservoirs occur as well developed meanders and cutoffs with crevasse splays and overbank sandstones adjacent to deltaic muds and levy deposits. Distributary channels are capped by shale and/or thin limestones that act as an effective seal for gas and/or oil accumulations.

\section{GEOLOGY OF HEAVY OIL SANDS}

\section{Gas Reservoirs With Associated Heavy. Oil}

Polo, Avondale, Liberty, Paradise, South Plattsburg, Hammand, Lathrop, and Turney Gas Fields in Caldwell, Clay, and Clinton Counties, Missouri have depleted gas reservoirs containing unproduced heavy oil resources (Table 3.1 and Fig. 3.2). The "Knobtown Sand" is fine-grained, micaceous sandstone, locally lenticular, grading laterally into sandy limestones or sandy shale that yield shows of oil and/or gas, with a thickness of $5 \mathrm{ft}$ to $25 \mathrm{ft}$, when productive. The Bandera Quarry Member (Polo Sand) varies from coarse "quartzite" sandstone to limey, shaly sandstone or shale with clay and sandstone lenses and has vertical variation in porosity and permeability. The Polo Sand ranges in thickness from $0 \mathrm{ft}$ to $25 \mathrm{ft}$. The Lagonda formation ("Squirrel Sand") is a 20 $\mathrm{ft}$ to $40 \mathrm{ft}$ thick, fine to medium grained, micaceous, sandstone with calcium cement. The Labette Formation grades downward from fine silts at the top to coarse sand at the base. Porosity and permeability are affected by lateral changes in the amount of shale and calcareous cements. Deason

TABLE 3.1. - Gas reservoirs with heavy oil resources

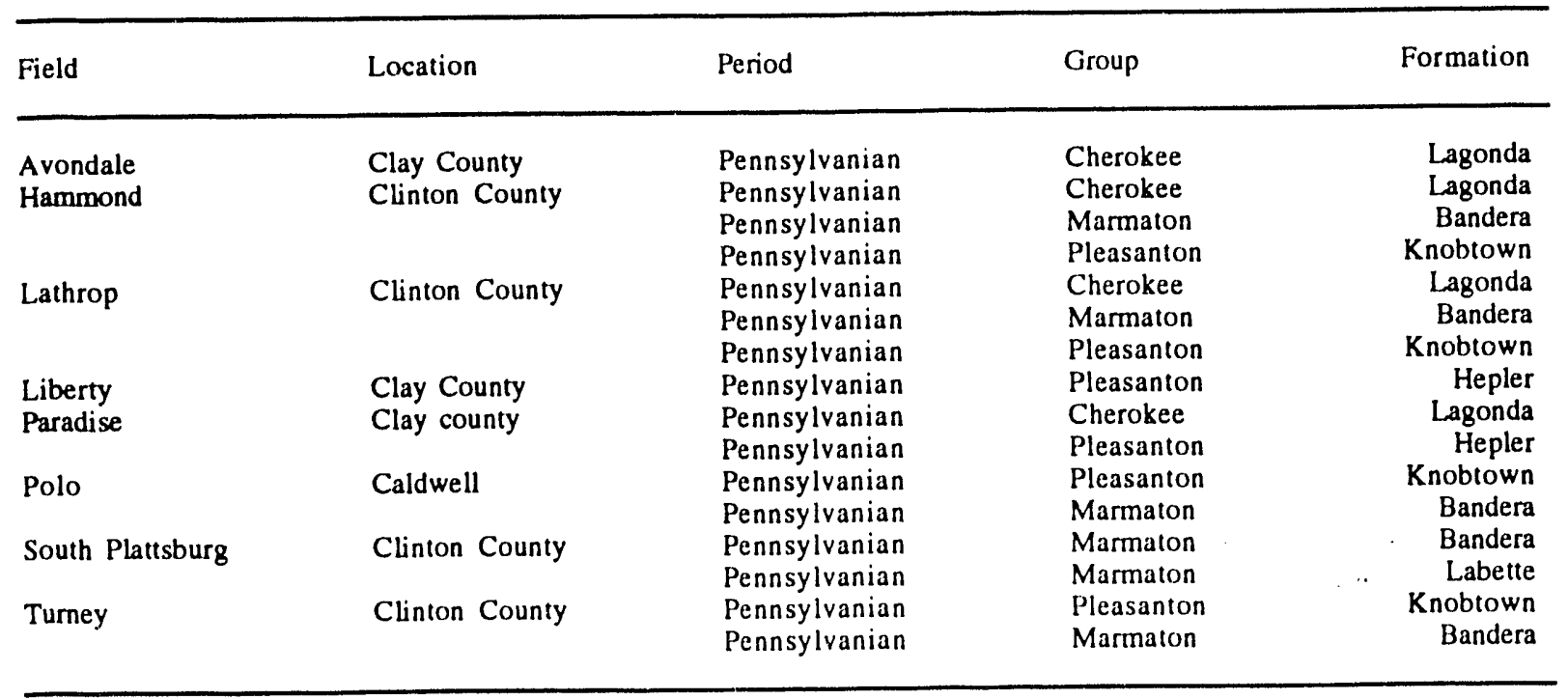




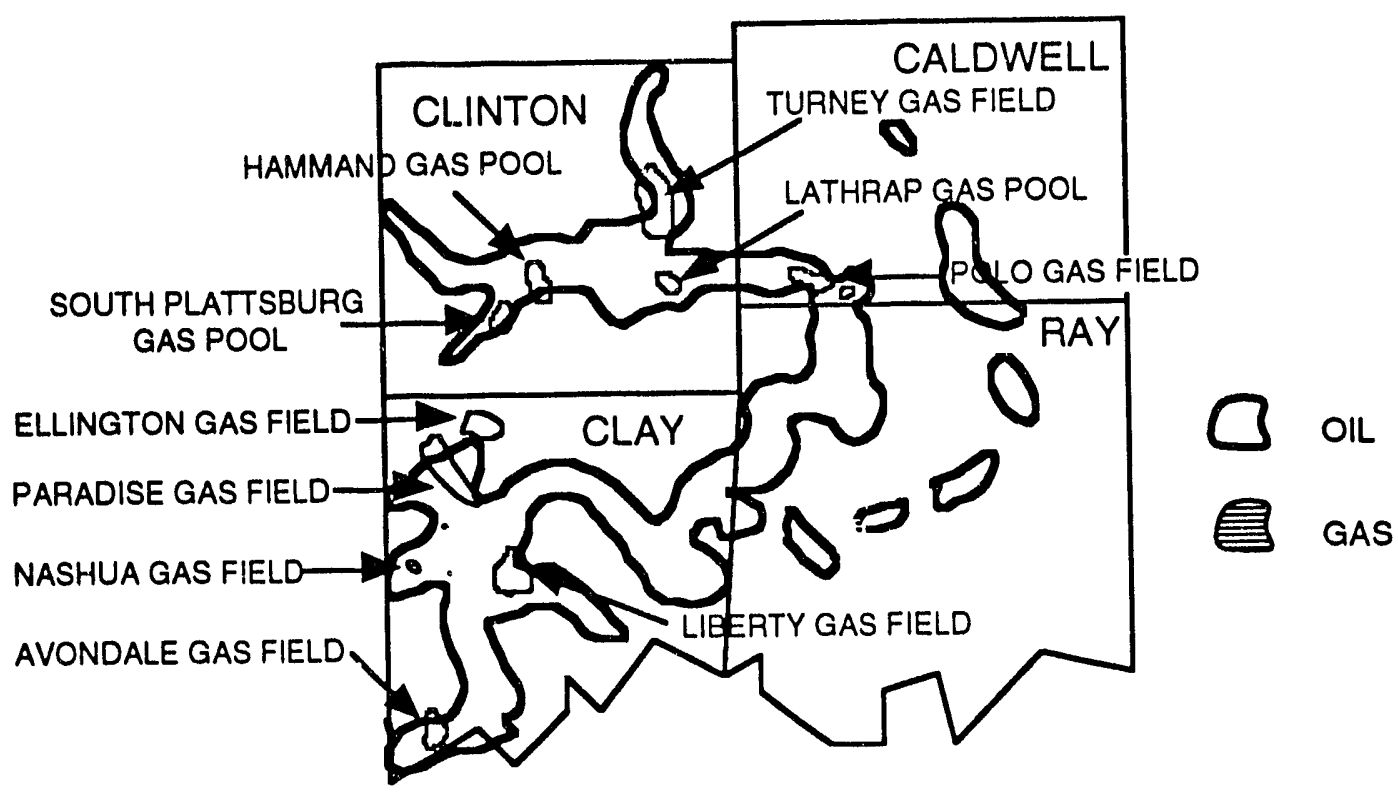

FIGURE 3.2. - West Central Missouri Oil and Gas Fields.

(1969) suggests that the $566,660 \mathrm{cu} f \mathrm{ft}$ to $240,000,000 \mathrm{cu} \mathrm{ft}$ of remaining unproduced gas reserves in Polo Gas Field may be used to produce heavy oil associated with gas in the field. About 265 barrels of oil were produced from the Liberty Gas Field, but there was no mention of gravity or viscosity in the reference (Deason, 1969)

\section{Heavy Oil Reservoirs}

Heavy oil deposits have been reported in several counties of western Missouri in the Cherokee and Forest City basins (Chapter 2, Fig. 2.1). The general area of these deposits extends from Barton County in southwestern Missouri to Caldwell County, northeast of Kansas City. The thicker, shallower, more concentrated (heavy oil sands are sometimes stacked) sandstone deposits are found in Barton, Vernon and southern Bates Counties (Fig. 3.3). These counties with shallower heavy oil deposits lie in the area of the Bourbon Arch. The Bourbon Arch is the structural feature separating the Cherokee and Forest City Basins (Chapter 2, Fig. 2.1).

Major heavy oil bearing sandstones in western Missouri are those of the Atokan and Desmoinesian Series, Pennsylvanian System (Fig. 3.1). The individual sandstones were formaliy parts of the Weir, Bluejacket, Warner, and Riverton Formations (see Fig. 3.1). The sandstones, shales, siltstones, claystones and limestones of these formations in the lower Pennsylvanian were deposited in a fluvial-dominated deltaic system. Sandstones in these formations were deposited as distributary channel, crevasse splay, point bar, and possibly braided stream deposits. These sandstones may be from $35 \mathrm{ft}$ to $60 \mathrm{ft}$ in thickness (Tomes, 1986; Netzler, 1990). 


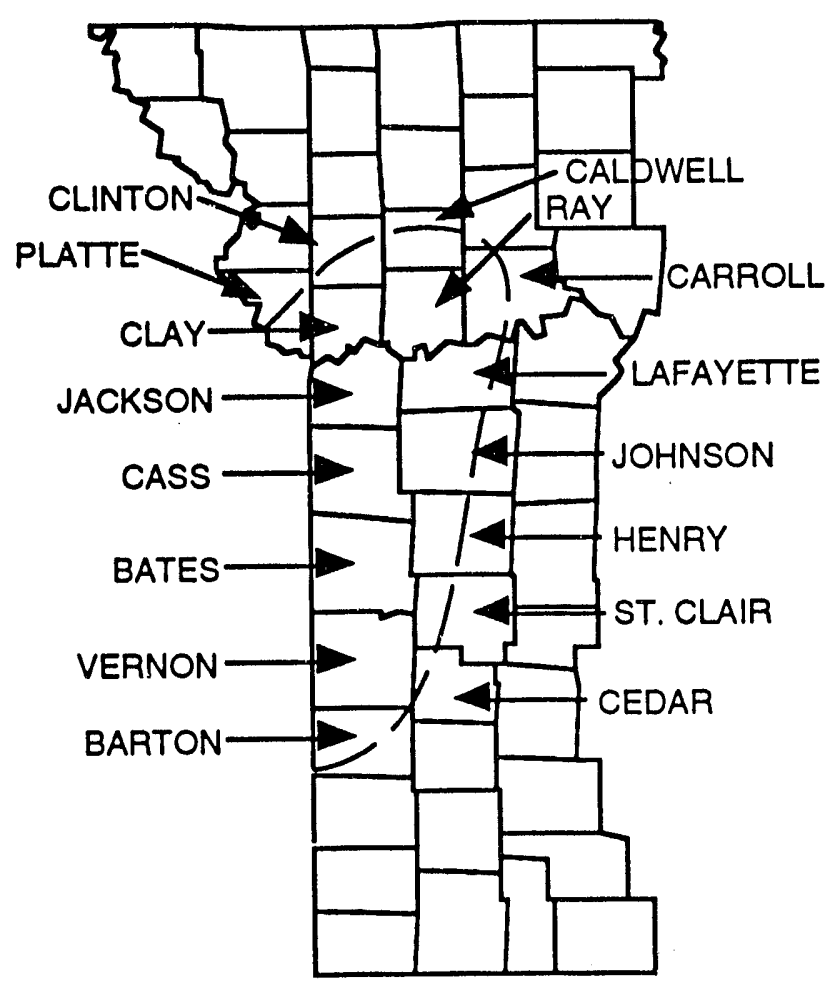

FIGURE 3.3. - Map of Heavy Oil Occurrences in Missouri (from Netzler, 1989).

\section{PENNSYLVANIAN PERIOD}

\section{Atokan Series}

The lower Warner Sandstone has been assigned to the Riverton Formation, Atokan Series, Pennsylvanian Period by the Missouri Geological Survey (Fig. 3.1). Atokan sediments in Missouri are dominated by clastic deposits caused by repeated progradation of fluvial-dominated deltaic systems westward into Kansas and Oklahoma (Ebanks, 1977). These quartz sand-rich prograding streams deposited highly lenticular, curvilinear, and discontinuous sandstones over mud, silt, or peat swamp deposits. These sandstones, with an unpredictable pattern, are commonly 10-ft to 15-ft-thick with a maximum thickness of 40-ft (Wells, 1979; Ebanks, 1977).

Lower Warner sandstone varies widely in reservoir quality rock. It consists of interbedded fine silt and dark shale through dirty, clayey siltstone, to clean, coarse-grained quartz sandstone. Grain size and sedimentary structures vary from large-scale cross bedding with coarser grains to small-scale or ripple cross bedding and horizontal thin laminae with fine- and very-fine-grains. Lower portions of a unit commonly have carbonaceous material and thin coal laminae (Wells, 1979). 


\section{Desmoinesian Series, Cherokee Group}

Upper Warner, Eastburn, Bluejacket, and Lagonda formations are members of the Cherokee Group in Missouri (Fig. 3.4). The upper Warner interval consists of sandstones and shales with an upper boundary at the Rowe Coal. Upper Warner sandstone of Missouri is younger than sandstone of the Warner at the type locality in Oklahoma. Absence of the Rowe and Drywood formations east of Navada, Missouri cause difficulty in identification of the upper Warner. Erosion by streams cut channels into the Rowe and Drywood formations, sometimes removing them and cutting channels into the underlying upper Warner formation. These channels were later filled with younger sandstones, Eastburn sandstone and/or lower Bluejacket. Thickness of the upper Warner sandstone is commonly $30 \mathrm{ft}$ to $40 \mathrm{ft}$, but may reach a maximum thickness of $90 \mathrm{ft}$. Lenticular sandstone bodies of the upper Warner may be poorly cemented (friable) to well cemented fine-, medium- to coarse-grained micaceous sandstone deposited by a fluvial-dominated deltaic system (Wells and Anderson, 1968). These sediments were deposited in distributary channel systems on a westward prograding, hi-constructive, delta lobe. Point-bar deposits are common in a meandering distributary system and file channels cut into the underlying Mississippian terrane. Some of the sandstones of the upper Warner fall into the subarkose range of Folk's classification because of the quartz-feldspar-rock fragment ratio (Tomes, 1986).

In Table 3.2, Facies $\mathrm{H}-2$ serves as an effective seal for upward migrating oil in the upper Warner. The fine-grained laminae of this facies blocks migration of oil upward from the H-3 Facies. Ripple, trough bedded sandstone of Facies H-3 is an excellent reservoir for heavy oil in western Missouri. Diagenetic changes in upper Warner sandstones stopped when oil migrated into unfilled pore spaces. Heavy oil in upper Warner sandstone reservoirs became heavy oil through biodegradation by anaerobic bacteria, water washing by fresh water in near surface conditions, and loss of light ends. Bitumen (dead oil) commonly is found beneath heavy oil saturated zones and in the upper two facies (H-1 and H-2) of the upper Warner sandstone (Tables 3.2 and 3.3) (Ebanks and James, 1974; Tomes 1986; Netzler, 1990).

The Eastburn sandstone has a stratigraphic position between the upper Warner formation and the lower Bluejacket (Bartlesville) formation (Fig. 3.4). Carmel Energy, Incorp. delineated the Eastburn sandstone after implementation of their patented Vapor Therm TEOR process in the Eastburn Field, Vernon County, Missouri. Stratigraphically, the Eastburn sandstone is a member of the Bluejacket formation. Prior to the Carmel Energy project, this sandstone had been identified as the lower Bluejacket sandstone. The lower Bluejacket sandstone is separated from the Eastburn sandstone by a discontinuous thin coal bed or limestone stringer. Under local conditions where the coal bed or limestone are absent, this sandstone unit is identified as the lower Bluejacket 


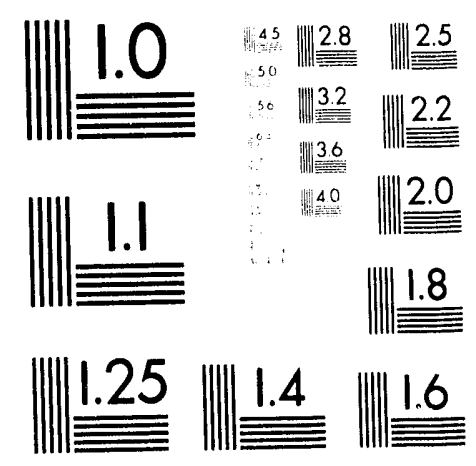



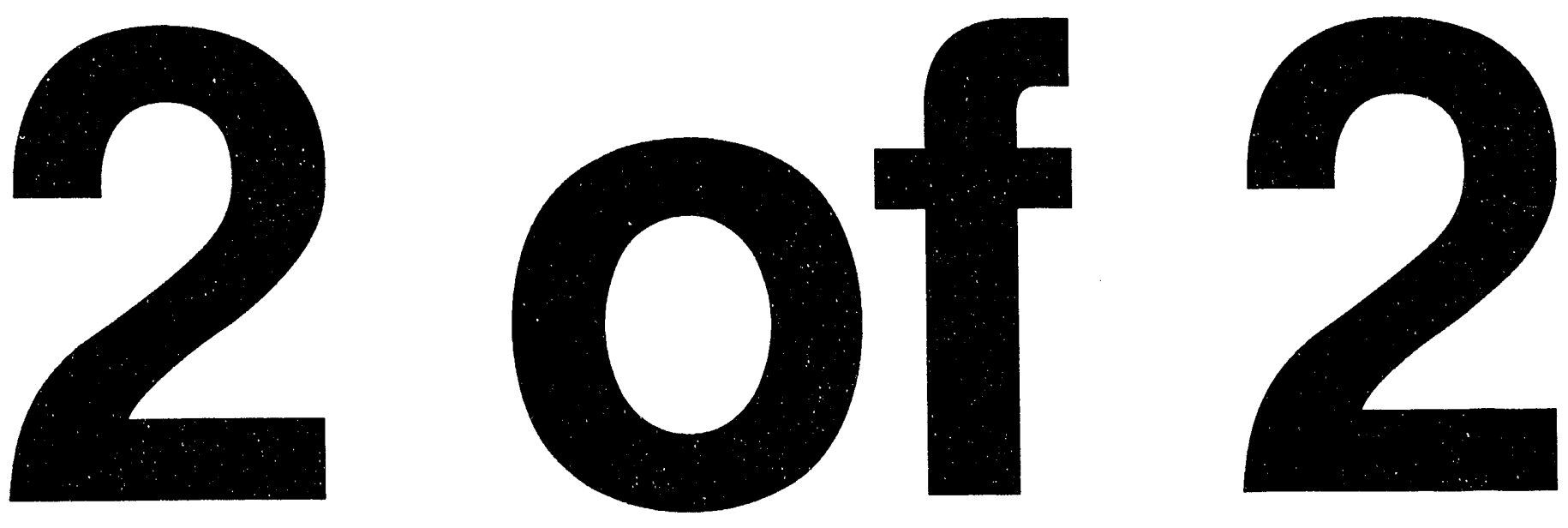


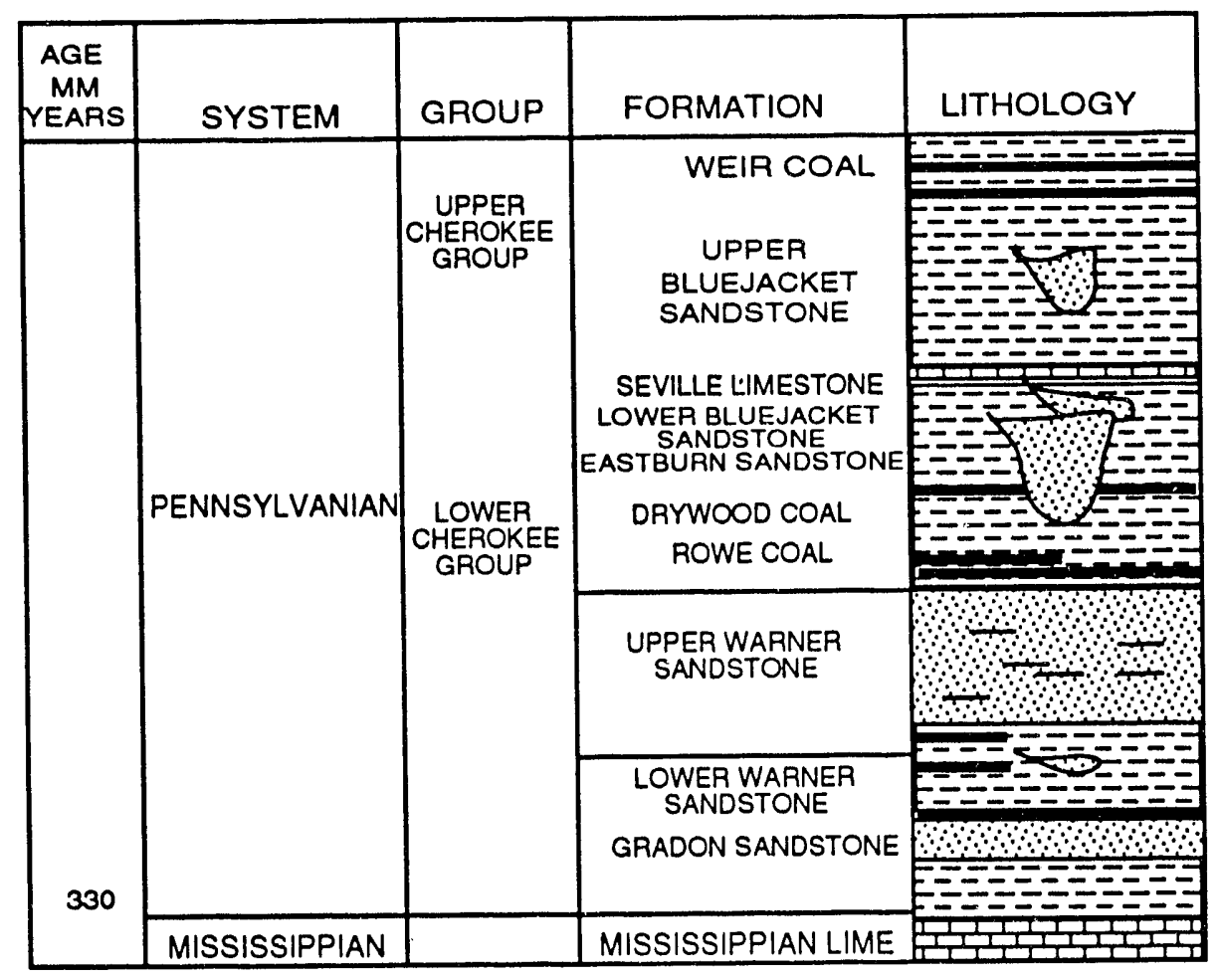

FIGURE 3.4. - Oil Bearing Sandstones in Western Missouri.

TABLE 3.2. - Sandstone facies of the Upper Warner Formation (Tomes, 1986)

\section{Facies}

Description

Commonly occurring at the top, massive bedded, very-fine-grain, abundant zones with early diagenetic siderite and shaley laminae. Heavy oil staining and residual bitumen are not commonly present at the top of the upper Warner. This facies may occur just above the shale pebble conglomerate (Facies $\mathrm{H}-5$ ). $\mathrm{H}-1$ is not an important oil bearing zone.

Very-fine-grained, parallel laminated sandstone with laminae composed of diderite, altered phyllosilicates, and muscovite. These "nae are significant barriers to vertical permeability. This facies has a gradational contact with $\mathrm{t} i \mathrm{~s}$ uerlying $\mathrm{H}-1$ Facies. The $\mathrm{H}-2$ Facies is one of the two important oil bearing facies of the upper $W$ arner because of its volume and stratigraphic position.

Very-fine-grained, ripıle trough crossbedded sandstone, with multiple stacked sequences of ripple trough cross laminae having climbing ripple sequences. This facies has the largest sediment volume within the upper Warner. Heavy oil saturation to bitumen (dead oil) occurs without a change in sedimentary structures or lithology in this facies. Contact with the overlying $\mathrm{H}-2$ facies is gradational.

Fine- to medium-grained, Planar crossbedded sandstone deposited near the base of the upper Warner. This facies has the best reservoir characteristics because of its stratigraphic position near the base, but usually contained dead oil. The low volume of sediment in this facies makes it too thin for significant contribution as an oil reservoir.

Shale pebble conglomerate located at the base of the upper Warner. 
TABLE 3.3. - Inferred paragenetic sequence of the "Upper Warner" Sandstone, Vernon County, Missouri (Tomes, 1986)

\begin{tabular}{|c|c|c|}
\hline Stage & Diagenetic features & Paragenetic sequence \\
\hline 1st & Siderite, Pyrite, FeO nodules & $\begin{array}{l}\text { Well developed siderite "eyes" displace detrital grains; only } \\
\text { common in shaly zones; FeO nodules deform adjacent laminae. }\end{array}$ \\
\hline 2nd & Quartz overgrowths & $\begin{array}{l}\text { Syntaxic quartz overgrowths formed on clay-free grains. Euhedral } \\
\text { quartz faces often bounded by sparry calcite. First diagenetic } \\
\text { mineralization in cleaner intervals. }\end{array}$ \\
\hline 3 rd & Sparry calcite & $\begin{array}{l}\text { Low packing indices of quartz associated with calcite indicates } \\
\text { early emplacement. }\end{array}$ \\
\hline 4 th & Secondary porosity & $\begin{array}{l}\text { Remnant pieces of calcite and calcite replaced grains in enlarged } \\
\text { pores. }\end{array}$ \\
\hline Sth & Kaolinite, rutile & $\begin{array}{l}\text { Euhedral kaolinite "books" and acicular rutile present in secondary } \\
\text { pores in minor amounts. }\end{array}$ \\
\hline 6 th & Hydrocarbons & $\begin{array}{l}\text { Preservation of diagenetic mineralization in oil bearing zones and } \\
\text { alteration in water bearing zones (i.e., illite pseudomorphous after } \\
\text { kaolinite. }\end{array}$ \\
\hline 7th & Meteoric flushing & $\begin{array}{l}\text { Bitumen in pores and low gravity oil are evidence of loss of } \\
\text { lighter end volatiles. }\end{array}$ \\
\hline
\end{tabular}

sandstone. These two sandstones are difficult to distinguish (Netzler, 1990). The Eastburn sandstone is discontinuous laterally and only identified in Barton and Vernon counties in western Missouri. The stratigraphy and depositional sequence of this sandstone were delineated only after Carmel Energy experienced some problems in implementation of the Vapor Therm Process. The Eastburn sandstone was deposited as a channel-fill, point-bar deposit by a fluvial-dominated deltaic system (Bradshaw, 1985).

The upper facies (channel fill or point bar) of the Eastburn sandstone is fine-grained with medium-scale sedimentary structures, (crossbeds, horizontal beds and massive beds). The upper facies sandstone is fine-to very-fine-grained with small-scale ripples. Separation of the Eastburn sandstone into upper and lower facies is based upon grain-size, mineralogy, and sedimentary structures occurring in stratigraphic succession in the sandstone (Table 3.4) (Bradshaw, 1985).

Moderately sorted, fine- to very-fine-grained sediments in the upper facies are within the dimensions of a thin section. Permeability inhibiting silty layers are distributed throughout the upper facies interval. Preferred horizontal orientation of sand grains in the framework controls the pore network in this facies. Because of the random distribution of silty layers in the upper facies, average permeabilities of $452 \mathrm{mD}$ (in 2 wells) and $253 \mathrm{mD}$ (in 1 well) proved to be inadequate for economic recovery of heavy oil in Eastburn Field. Permeability measurements in the upper facies are deceiving because of combined variables which create poor reservoir quality rock. Horizontal and vertical permeabilities are reduced because of silty layers that inhibit fluid movement across 
TABLE 3.4. - Stratigraphic sequence of the Eastburn sandstone Eastburn field, Vernon County, Missouri (Bradshaw, 1985)

\begin{tabular}{|c|c|}
\hline Unit & Description \\
\hline 1 & $\begin{array}{l}\text { Basal conglomerate } 6 \mathrm{~cm} \text { thick containing limestone, siderite, and unidentifiable pebbles replaced by } \\
\text { pyrite. }\end{array}$ \\
\hline 2 & $\begin{array}{l}\text { Sandstone that is laterally continuous with each separate point-bar body with medium-scale sedimentary } \\
\text { structures, (horizontal, parallel bedding, massive-bedding, crossbedding, and slumped crossbedding). }\end{array}$ \\
\hline 3 & Sandstone and silt with rippled and horizontal bedding. \\
\hline 4 & $\begin{array}{l}\text { Silty shale overlying the sandstone of Unit } 3 \text { contains small lenses of sandstone } \\
(2-4 \mathrm{~cm} \text { thick) randomly throughout the zone. }\end{array}$ \\
\hline 5 & Silty clay, underclay and a thin coal bed occur immediately above Unit 4. \\
\hline NOTE: & $\begin{array}{l}\text { Thickness of the stratigraphic sequence within the sandstone is highly variable within short distances } \\
\text { because of thickness irregularities in the upper rippled sandstone. }\end{array}$ \\
\hline
\end{tabular}

their boundaries. Grain-size distribution in the upper facies is bimodal, reducing heavy oil production recovery efficiency. Small pore size and high average pore-to-throat ratio further reduce the reservoir quality of the upper facies. Combined, these characteristics produce poor reservoir quality sandstone in the upper facies (Chapter 2, Figs. 2.46 through 2.47).

Lower facies (channel fill or point bar) sandstone that is well-sorted, fine-grained and with relatively uniform thickness was deposited below upper facies sandstone of the Eastburn sandstone. Massive-bedded zones have no preferred grain or porosity orientation, but horizontally and crossbedded zones have preferred grain orientations which dictates porosity and permeability distribution. Preferred grain orientation of horizontal and crossbedded zones concentrate larger connected pores parallel to bedding planes while small connected pores that are parallel to bedding planes are located between bedding planes having less connectivity (Chapter 2, Figs. 2.46 through 2.47) (Bradshaw, 1985).

Depositional histories of the upper and lower facies of the Eastburn sandstone resulted in sorting, grain-size, and sedimentary structure variation that caused permeability variations within the sandstone. Permeability reduction in the upper facies has been caused in part by calcite cementation of fine-grained layers. The lower facies of the Eastburn sandstone has better reservoir quality and a fairly constant thickness of $12 \mathrm{ft}$ to $16 \mathrm{ft}$ (Figs. 3.5 through 3.6) (Bradshaw, 1985).

The Lower Bluejacket sandstone is the second best developed sandstone deposit after the "Upper Warner" sandstone and also second in hydrocarbon content after Warner sandstones (Fig. 3.4). This sandstone is mined for road blacktopping material by Silica Rock Products in a quarry located in Sec. 24, T34N, R30W near Bellamy, Missouri. Lower Bluejacket sediments were deposited as channel fill in distributary channels in a fluvial-deltaic environment (Wells, 1979). 


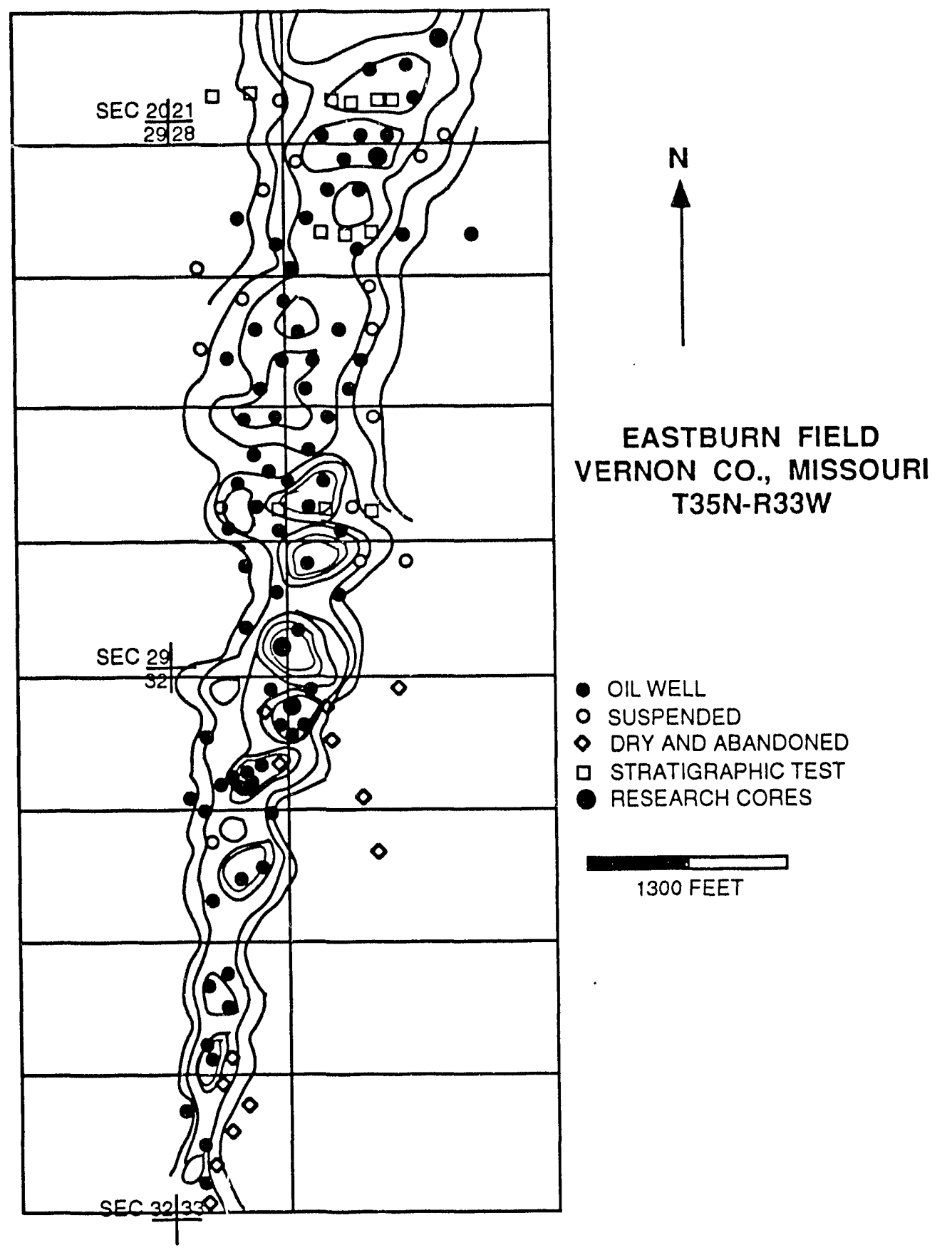

FIGURE 3.5. - Isopachous Map of Eastburn Sandstone, Eastburn Field, Vernon County, Missouri (from Bradshaw, 1985). 


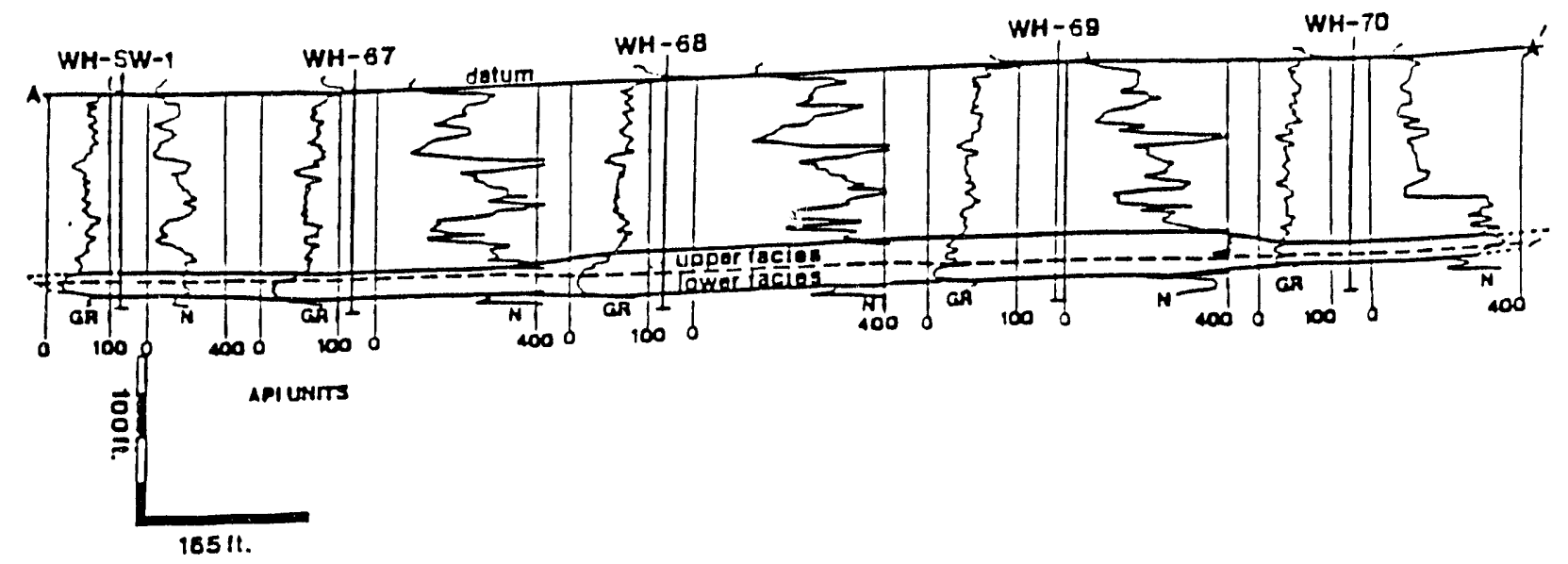

FIGURE 3.6. - Stratigraphic Cross Section of Eastburn Sandstone (from Bradshaw, 1985).

The lower Bluejacket may be the most widespread of the Desmoinesian Series sandstones. Where the Bluejacket sandstone fills channels cut through the Rowe-Drywood interval into the upper Warner, it is as thick as the upper Warner sandstone, but thinner in most other channel fills. The lower Bluejacket sandstone averages $15 \mathrm{ft}$ to $20 \mathrm{ft}$ in thickness and sometimes attains a maximum thickness of $35 \mathrm{ft}$. It is thin-bedded, fine- to medium-grained, micaceous, medium to massive cross-bedded, grading laterally into siltstone and shale, poor reservoir quality sandstone with poor sorting and an abundance of fined and matrix materials. Gradation from fine-grained sandstone to siltstone to thinly-laminated silty shale in a relatively short distance contributes to poor reservoir quality sandstone (Wells, 1979).

Lower Bluejacket and upper Warner sandstones are sometimes difficult to distinguish in the field (Wells and Anderson, 1968). Outcrops of the lower Bluejacket are asphaltic in southern Vernon and northern Barton Counties, Missouri. In places where it has been mined, it is not a true road asphalt because additional asphalt must be added for binding material. This sandstone has been a less prolific oil producer in the Forest City Basin of Missouri than it has in Kansas (Wells, 1979).

Upper Bluejacket sandstone is silt-size to medium-grained, thin bedded, often thinly laminated sandstone grading laterally to silts, and shales deposited as fill in distributary channels in a fluvial-dominated deltaic environment (Fig. 3.4). These lenticular sandstones have limited 
horizontal and vertical extent. In thicker channel-fills the sandstone may be cleaner and coarser with some crossbedding. Average thickness is less than $10 \mathrm{ft}$, but has a maximum thickness of 25 $\mathrm{ft}$ in northern Vernon County Missouri. This sandstone is the poorest reservoir quality rock of all of the sandstones in the Desmoinesian Series in Missouri (Wells, 1979).

The Lagonda Formation was deposited as channel-fill, argillaceous and clayey siltstone to a fine- to medium grained sandstone in distributary channels in a fluvial-dominated deltaic environment (Fig. 3.1). This sandstone is commonly known by the name Squirrel sandstone as an oil and gas reservoir. More oil and gas have been produced from this formation than from other sandstones in Missouri. Average thickness is about $50 \mathrm{ft}$ in western Missouri with $20 \mathrm{ft}$ of clean sandstone, attaining a maximum thickness of 95 feet. Position of the sandstone within the Lagonda Formation may vary vertically. Asphalt and heavy oil occurrences in the Squirrel sandstone in Missouri are not common. An asphalt occurrence along the outcrop in Rich Hill, Bates County, Missouri has been reported. Heavy oil and dead oil shows have been reported in subsurface shows in western Bates County, Missouri (Wells and Anderson, 1969).

\section{Desmoinesian Series, Marmaton Group}

The Labette Formation, Englevale sandstone member, was deposited as a channel fill in a distributary channel in a fluvial-deltaic environment (Fig. 3.1). This sandstone is commonly called the Peru sandstone. This sandstone has an average thickness of $25 \mathrm{ft}$ and may be found at depths of $50 \mathrm{ft}$ to $200 \mathrm{ft}$ in western Missouri (Wells and Anderson, 1969).

The Bandera Quarry Sandstone is a coarse quartzite sandstone to lime, shaly sandstone or shale with clay and sandstone lenses with varying vertical porosity and permeability (Fig. 3.1). This sandstone was deposited as channel-fill by a fluvial-dominated deltaic system. It is commonly known as the Polo sandstone as an oil and gas reservoir in western Missouri counties of Bates, Caldwell, Clay, and Platte. Maximum thickness is $50 \mathrm{ft}$ with 5 to $10 \mathrm{ft}$ more common (Wells and Anderson, 1969).

The Warrensburg Sandstone is a sandstone within the Perry Farm Member of the Lenapah Formation (Fig. 3.1). This is a gray, calcareous, sandstone that grades laterally into red shale at the top. It was deposited as channel-fill in a fluvial-dominated deltaic system. Locally, it is also known as the Peru by drillers. The Warrensburg sandstone is an oil reservoir in Jackson County, Missouri (Wells and Anderson, 1.969).

\section{Missourian Series, Pleasanton Group}

The Hepler sandstone is also known as the Wayside by drillers in Missouri (Fig. 3.1). It is a calcareous sandstone deposited as a channel-fill by a fluvial-dominated deltaic system. The Exline limestone is the cap rock for Hepler oil reservoirs in western Missouri. This sandstone is regional 
in extent and widespread in the subsurface of western Missouri. It may be $0 \mathrm{ft}$ to $35 \mathrm{ft}$ thick but more commonly $1 \mathrm{ft}$ to $15 \mathrm{ft}$ (Wells and Anderson, 1969).

The Knobtown sandstones were deposited as channel-fill by a fluvial-dominated deltaic system and in a marine system (Fig. 3.1). This sandstone commonly has upper and lower sandstone lenses. The lower sandstone is formally recognized as the Warrensburg Member and may either be a calcareous marine sandstone or a channel-fill sandstone. The sandstone above the Warrensburg is a fine-grained, micaceous channel-fill sandstone. The upper sandstone sometimes fills channels cut into the lower channel. Heavy oil is found in the Knobtown sandstone in Lafayette, Carroll, Caldwell, and Ray counties, Missouri.

\section{STRUCTURAL FEATURES}

The outcrop of Pennsylvanian rocks in Missouri is aligned in a northeast-southwest direction with regional dip to the northwest. The Forest City Basin is the prominent Paleozoic depositional basin in northwest Missouri (Fig. 2.1). The Cherokee Basin is the prominent Paleozoic depositional basin in southwest Missouri (Fig. 2.1). The Bourbon Arch is the major tectonic feature that separates the Forest City and Cherokee basins. The Bourbon Arch extends from the Ozark Dome in Missouri northwestward across Vernon County into Kansas and ends at the intersection with the Nemaha uplift (Chapter 2, Fig. 2.1). Moore and Jewett (1942) named the Bourbon Arch (Wells and Anderson, 1969).

Heavy and light oil and gas accumulations in western Missouri are associated with stratigraphic, structural-stratigraphic, and structural traps. Shallow heavy oil accumulations in channel-fill sandstones in the Cherokee Basin of southwestern Missouri are stratigraphic traps, while heavy oil associated with gas production in the Forest City Basin of northwestern Missouri are structural or structural-stratigraphic traps (Wells and Anderson, 1968).

Natural fracturing is present in rocks of the Cherokee and Forest City Basins. The primary alignment direction is approximately northeast-southwest with a secondary set of fractures in a northwest-southeast direction. These natural fractures, when associated with oil accumulations, may cause production and environmental problems when implementing TEOR processes (linedrive and leakage to the surface).

\section{CASE HISTORIES OF HEAVY OIL OPERATIONS}

\section{Phillips Petroleum Company (1955 to 1958)}

In early 1955, Phillips Petroleum Company began testing a counterflow in situ combustion process to produce heavy oil in southwestern Missouri near Bellamy. Before startup of the counterflow system, a direct drive in situ process was unsuccessfully implemented. The direct drive process moved the combustion front and injected air in the same direction. This process was 
unsuccessful because the front of light oil distilled ahead of the combustion of the heavy oil congealed as it moved forward forming a gas permeability barrier that smothered the combustion.

The counterflow combustion process, developed by Trantham and Marx of Phillips (1966), injected air from the opposite direction of the combustion front. Air forced the heated, thinned oil through the combustion front keeping the gas pe rmeability barrier from forming. The thermally cracked lighter hydrocarbon products passed through the fire front, mostly in the vapor phase, and did not create a gas permeability barrier.

Several possible locations for field testing the underground counterflow combustion process were cored and evaluated before selection of the Bellamy site in western Missouri. The heavy oil sand selected was 12 feet thick, between 49 and 61 feet below the surface, with confining and sealing beds above and below as siltstone and shale, respectively. The 12 feet of heavy oil sand, having an upper, less permeable zone and a lower, more permeable zone, was part of a larger 30 feet of "tar" sandstone deposited above and below the test zone. Seven different spacing patterns were used. Examples of the patterns used were: (1) a 15-well line-drive pattern, (2) a 10 well radial pattern, (3) a five-spot pattern, and (4) a seven-spot pattern (Table 3.5).

Phillips Petroleum proved that heavy oil could be produced from shallow consolidated sandstone by in situ combustion using the counterflow air injection. Upon ignition of the oil, the heat of combustion caused the consolidated sandstone reservoir to fracture because of the change in temperature. Air transmissibility through the reservoir sandstone increased approximately 20 times as the combustion front passed through the sandstone. Production wells at the test site were produced as high temperature condensate wells with no artificial lift. Emulsions and corrosion did not appear to cause problems during this test (Netzler, 1990).

The lower, more permeable facies of the 12 feet of heavy oil sandstone probably contributed most of the oil recovered in the counterflow in situ combustion project. Fracturing of the sand probably created line drive mechanisms to the producing wells which may cause oil to be bypassed at this shallow depth. Part of the oil recovered may have been produced from the 30 feet of "tar" sandstone when it was heated due to gravity drainage. Use of this process in extremely shallow, "grass roots," consolidated heavy oil saturated sandstones has the potential for creating environmental problems and air pollution.

TABLE 3.5. - Phillips Petroleum Company (1955-1958) counterflow in situ combustion process (Bellamy, Missouri)

\begin{tabular}{ll}
\hline Reservoir depth, ft & $49-61$ \\
Average thickness, ft & 12 \\
Well patterns, -- spot & $10,7, \& 5$ \\
$\quad$ line-drive & 15 \\
Air transmissibility increase, .- fold & 20 \\
\hline
\end{tabular}




\section{Carter Oil Company -. Deerfield Steam Drive Test (1955-1959?)}

The Deerfield Steam Drive Test was performed by the research and production departments of Carter Oil Company. This pilot was conducted in the Warner sandstone containing $18^{\circ} \mathrm{API}$ gravity oil with a viscosity of $1,000 \mathrm{cP}$ at the original reservoir temperature of $60^{\circ} \mathrm{F}$. The Warner Formation at the Deerfield, Missouri, pilot test site is at a depth of $160 \mathrm{ft}$. Steam was injected into nine input wells in an inverted five-spot pattern. Fourteen temperature observation wells were used. Late in the life of the pilot test, ammonia was injected as a tracer to determine the flow paths of the steam and oil.

The Warner reservoir is fine- to medium-grained, micaceous sandstone with a total thickness of $42 \mathrm{ft}$ containing $26 \mathrm{ft}$ of effective heavy oil pay. The oil pay is composed of $17 \mathrm{ft}$ lower sandstone containing very heavy asphaltic material that will not flow when stimulated by steam. The $26 \mathrm{ft}$ of effective pay has a lower $5 \mathrm{ft}$ that is dead oil and $21 \mathrm{ft}$ of heavy oil that will respond to steam stimulation. This test proved that oil is recoverable from shallow channel-fill sandstones in Missouri by recovering 6,752 barrels of heavy oil by steam drive. Production recovery of 6,752 barrels of oil over a 4-year test (length of the project not certain) demonstrates that oil is recoverable by steam drive, but this quantity of oil does not demonstrate the economic feasibility of heavy oil recovery in "thin" consolidated fluvial deltaic sandstones of the Cherokee Group in the Midcontinent (Table 3.6) (Netzler, 1990). The recovery efficiency or \% of OOIP recovered are unknown.

\section{Shell Oil Company (1963-1966)}

During 1963, Shell Oil Company purchased 80 acres in Sec. 8, T36N, R33W, in Vernon County, Missouri. In keeping with Shell policy, then and now, data accumulated during testing various thermal processes for oil recovery were not released. Therefore, information related to the project is sketchy. Before pilot testing started, an estimated 600 test holes were drilled. The heavy oil zone, tested with various thermal processes, was a sandstone in the Warner Formation at a depth of 250 feet. Oil recovery during testing was estimated to be 346 barrels during combustion pilot tests and 6,600 barrels during steam pilot tests over a two-year period of time. During pilot testing for both combustion and steam processes, 2.5 -acre inverted five-spot patterns were used (Netzler, 1990).

The recovery of 6,600 barrels of heavy oil during the pilot testing of steam indicates that the use of steam will recover heavy oil from sandstone(s) of Warner Formation age. Recovery of heavy oil with steam or another thermal process is probably dependent upon the depositional environment of the facies impregnated with heavy oil that may respond to viscosity lowering during application of the process. No geological description of the Warner sandstone in their test 
TABLE 3.6. - Carter Oil Company (1955-1959) steamdrive test, Deerfield, Missouri

$\begin{array}{lr}\text { Average depth, } \mathrm{ft} & 160 \\ \text { Average total thickness, } \mathrm{ft} & 43 \\ \text { Average effective heavy oil thickness, } \mathrm{ft} & 26 \\ \text { Average bottom tar zone thickness, } \mathrm{ft} & 17 \\ \text { Average permeability (upper } 21 \mathrm{ft} \text { heavy oil zone), mD } & 540 \\ \text { Average permeability (lower } 5.2 \mathrm{ft} \text { heavy oil zone), } \mathrm{mD} & 184 \\ \text { Average oil saturation in } 26 \mathrm{ft} \text { at conclusion, \% PV } & 25 \\ \text { Average oil saturation in upper } 21 \mathrm{ft} \text { at conclusion, \% PV } & 17.5 \\ \text { Average oil saturation in lower } 5.2 \mathrm{ft} \text { at conclusion, \% PV } & 32.5 \\ \text { Gravity of oil, } \% \text { PI } & 18 \\ \text { Viscosity of oil, cP @ } 60^{\circ} \mathrm{F} & 1,000 \\ \text { Capacity-fraction of upper } 21 \mathrm{ft} \% & 93 \\ \text { Oil recovered during project, bbl } & 6.752\end{array}$

area is available. Economic recovery of heavy oil from "thin" consolidated fluvial-dominated deltaic sandstones of the Cherokee Group over the 3-year period of the Shell test is questionable. Closer spacing than 2.5 acres for wells in an inverted five-spot pattern may be necessary for improved oil recovery, but may not be economical (Table 3.7).

\section{Henry Petroleum Company (1965-1976)}

Henry Petroleum Company conducted an unsuccessful attempt at recovering heavy oil from a sandstone in Eastburn Field Sec. 33, T35N, R33W, Vernon County, Missouri. Very little information is available or, the Henry Petroleum operation, but it is believed that the process was injection of liquid nitrogen. The project was abandoned after startup with very little recovery of heavy oil. Carmel Energy, Incorp. conducted a successful thermal project in this field later in the 1970s and 1980s. The Carmel Energy thermal recovery project and geology of the Eastburn Field are discussed in another project analysis. The process used (gas repressurization) was probably the cause of failure of the Henry Petroleum Company project due to the low API gravity high oil viscosity and the rapid vaporization of nitrogen (Netzler, 1990).

\section{Jet Engine Test}

Netzler (1990) reported that an attempt was made by a company (unnamed) to recover heavy oil by injecting jet engine exhaust gases directly into a well. The test was apparently unsuccessful because no meaningful information is available, and the project was abandoned. In the case of this project, the process was the probable cause for unsuccessful implementation.

\section{Electrical Current Injection Test}

Netzler (1990) reported that an operator had attempted to recover heavy oil from a sandstone by heating the reservoir with electrical current. A large electric bill is the only result that has been reported. 
This reservoir was produced during World War I. No definite per well daily production range is known for the field prior to an indefinite date of abandonment. After reservoir evaluation, Jones-Blair designed a modified cyclic steam injection system similar to the Carmel Energy VaporTherm process. Jones-Blair utilized a reservoir conditioning pre-soak injection of 20 tons of carbon dioxide at temperatures up to $650^{\circ} \mathrm{F}$ and followed by a gradual increase of steam, carbon dioxide and other chemicals for permeability control. Injection-production cycles averaged 45 days. Heat applied to the reservoir was approximately 500 million BTU/well. Oil was produced by air lift.

The thermal project was developed with alternating rows of injection and production wells. The field has been abandoned since the decline of oil prices in 1986, but not because of reservoir depletion. The projec: produced 133,018 barrels of oil before abandonment (Table 3.8).

This project proves that heavy oil can be recovered from shallow oil reservoirs in western Missouri. Economics of thermal stimulation may not be favorable under present oil prices.

\section{Carmel Energy, Inc. (1978-present)}

The most successful thermal heavy oil recovery project was conducted through a cost-sharing contract in 1978 between Carmel Energy and the U. S. Department of Energy. Carmel Energy demonstrated its patented Vapor Therm process in the Eastburn sandstone, Cherokee Group, Pennsylvanian System in Eastburn Field, Vernon County, Missouri, in Secs. 28 and 33, T35N, R33W (Figs. 3.5 through 3.6). Henry Petroleum had a project in this field at a earlier date that was abandoned.

The Vapor Therm process involves injection of super-heated steam, nitrogen, carbon dioxide and other flue gases (Chapter 2, Fig. 2.56). Injection of hot vapors pressurize and heat the reservoir, causing a reduction in viscosity of the heavy oil. With the reduction of viscosity, heavy oil is easier to produce. Carmel Energy makes the claim that purification of feed water for the boiler is not necessary and no air pollution resulted from the flue gases injected into the reservoir. The Vapor Therm process was adapted to both cyclic or steam drive processes.

Carmel Energy operated the largest commercial heavy oil recovery project in Missouri. Thermal stimulation was suspended in 1986 corresponding to the decline of oil prices in 1986. Four years later approximately 5,500 barrels of heavy oil per year was still being produced as a result of previous thermal stimulation. At peak production, 10,000 barrels of heavy oil per month were produced from Eastburn Field with cumulative oil production exceeding 550,000 barrels of heavy oil (Netzler, 1990).

The geology of the Eastburn Oil Field was described by Bradshaw (1985) in a thesis as partial credit for a M.S. degree from Wichita State University. Eastburn Field is productive from a stratigraphic trap in a channel-filling, point-bar sandstone deposited by a fluvial-dominated deltaic 
TABLE 3.8. - Jones-Blair Reservoir Parameters Cyclic Steam and Carbon Dioxide Field Test Stotesbury Field, Vernon County, Missouri (1982-1987) (Netzler, 1990)

\begin{tabular}{lr} 
Gravity, ${ }^{\circ} \mathrm{API}$ & $19-23$ \\
Viscosity, cP & 609 \\
Reservoir temperature, ${ }^{\circ} \mathrm{F}$ & 60 \\
Average permeability, mD & 375 \\
Average pay thickness, ft & 25 \\
Depth to top of pay, ft & $185-200$ \\
Barrels per acre-ft & 1,000 \\
Oil saturation, \% & 70 \\
Water saturation, \% & 30 \\
Oil recovery during project, bbl & 133,018 \\
Average injection-production cycles, days & 45 \\
Carbon dioxide per-soak, tons & 20 \\
Carbon dioxide pre-soak temperature, ${ }^{\circ} \mathrm{F}$ & 650 \\
Heat applied to reservoir, million BTU/well & 500 \\
\hline
\end{tabular}

system which is a member of the Cherokee Group, Pennsylvanian Period, located stratigraphically between the lower Bluejacket sandstone and the "Upper" Warner sandstone. This sandstone unit is discontinuous laterally, only a few hundred yards wide, but extending for over 2 miles in a north to south direction of the filled channel cut. Bradshaw (1985) separated the "Eastburn" sandstone into an upper and a lower facies. The lower facies is the better of the two facies, being more continuous between wells in the south half of the Eastburn Field. The northern half of the Eastburn Field is dominated by the upper point-bar sandstone facies of the "Eastburn" sandstone.

Carmel Energy discontinued production of oil from the wells in the north half of the reservoir after producing 26,250 barrels of oil, while the southern half of the reservoir produced 109,629 barrels of oil during the same time period (Bradshaw 1985). The poor heavy oil recovery in the upper point-bar facies in the north half of the reservoir is due to the depositional environment, type of bedding, thickness of individual bedding type, position along stream in point-bar development during deposition, diagenetic changes, mineralogy, grain size, bedding boundary permeability barriers, and vertical and horizontal discontinuity of the facies of the sand body identified as the "Eastburn" sandstone. Eastburn Field is by far the most successful and best thermal recovery project that has been attempted in Missouri to date (Fig. 3.6).

Annual production of approximately 5,500 barrels of oil in 1991, 5 years after discontinuation of steam and gas injection. This is significant because the reservoir has sufficient insulation by confining beds above and below to retain some heat from previous injection of steam and combustion gases. After discontinuation of thermal stimulation in 1986, Carmel Energy injectied water into the reservoir. The injected water becomes a hot water flood as it is heated by the reservoir rock. The cumulative heavy oil produced by Carmel Energy is approximately $77 \%$ of the reported oil production in Missouri since 1966. 
Heavy oil resources in Eastburn Field are calculated by Carmel Energy as 2.9 million barrels of original-oil-in-place with an estimated 40 to $60 \%$ recovery efficiency by thermal recovery processes in the lower facies, while the upper facies in the northern portion of the field has a recovery efficiency of $10 \%$ or less. This estimate and recovery was quoted by Bradshaw (1985) from data furnished by Carmel Energy. Since Bradshaw started work on his thesis in the early 1980s, the field was extended to the south by Carmel Energy. It would appear, from the oil recovered by Carmel Energy to date, that future extension of Eastburn Field to the south may prove to be an economical venture if oil prices should stabilize at a significantly higher price (Table 3.9) (Bradshaw, 1985).

\section{Electromagnetic Energy Incorporated}

A heavy oil recovery project by Electromagnetic Energy, Inc. is testing the feasibility for using microwaves as a source for generating heat for stimulation. The test is being conducted in Eastburn Field, Vernon County, Missouri. Results are not available at the present time (Netzler, 1990).

\section{MW Inc.-Town Oil Company (1989)}

Old Bitterroot Field is the site of a redundant water drive injection test using horizontal wells as injection and production wells. Eleven wells have been drilled to a vertical depth of approximately 150 feet and horizontal displacement of 150 to $200 \mathrm{feet}$. Nine wells have lateral displacement in the direction of best permeability, and two have displacement perpendicular to the direction of best permeability. All of the wells are "short radius" lateral wells with horizontal displacement from vertical in a $\pm 20 \mathrm{ft}$ radius. Initial tests were unsuccessful, but additional testing is planned (Netzler, 1990).

\section{RESOURCE ESTIMATES}

Estimates of heavy oil in western Missouri have varied widely over the years. Wells and Heath published an estimate for western Missouri at 1.4 to 1.9 billion barrels in 1979 . This estimate came from a study area in western Missouri covering Vernon, Barton, Jasper, and the western portion of Cedar and Dade Counties. That area has been the traditional study area for estimating heavy oil resources with little or no mention of the amount of recoverable heavy oil contained in an estimate. Bradshaw (1985) quoted an estimated from Ebanks, James, and Livingston (1977) of "recoverable" heavy oil of 200 to 250 million barrels in western Missouri which is not believable under the geological conditions and environment of deposition and subsequent diagenesis of the sandstones which are now impregnated with heavy oil. Based on TEOR performance in the tight compartmentalized consolidated sandstone reservoirs of the 
TABLE 3.9. - Reservoir parameters, Vapor Therm TEOR process Carmel Energy, Inc. Eastburn field, Vernon County, Missouri (1978-1990) (Modified after Netzler, 1990)

$\begin{array}{lr}\text { Depth to top of sand, } \mathrm{ft} & 100-110 \\ \text { Net pay, ft } & 20-23 \\ \text { Structure } & \text { Channel } 1^{\circ} \text { dip } \\ \text { Sand grain size } & \text { Fine to very fine } \\ \text { Gravity, }{ }^{\circ} \mathrm{API} & 20-23 \\ \text { Porosity, \% } & 25 \\ \text { Permeability, mD } & 650 \\ \text { Oil saturation, \% } & 60 \\ \text { Reservoir pressure, psig } & 54 \\ \text { Oil viscosity, cP } & 700 @ 70^{\circ} \mathrm{F} \\ & 80 @ 100^{\circ} \mathrm{F} \\ & 40 @ 130^{\circ} \mathrm{F} \\ \text { Oil recovery, bbl } & 10 @ 210^{\circ} \mathrm{F} \\ \text { Thermal stimulation suspended, year } & 550,000 \\ \text { Oil recovery 4 years after stimulation suspended, BO/year } & 1986 \\ \text { Heavy oil reserves, OOIP bbl } & 5,500 \\ \end{array}$

Cherokee Basin Midcontinent, the economical recoverable and environmentally acceptable heavy oil (without extensive loss of fluid outside the reservoir) should be significantly less than aforementioned. The authors estimate $<5,000,000$ barrels of heavy oil are recoverable from Cherokee and Forest City Basin reservoirs.

Eastburn Field in western Vernon County, Missouri is considered to be a typical oil field for the area (Cherokee Basin) that contains heavy oil. The estimated heavy oil resource for Eastburn field is 2.9 million barrels (Bradshaw, 1985). The "Eastburn" sandstone is a lenticular, channel fill sandstone striking north-south with future probable development possibilities to the south where the lower productive facies is best developed. The above mentioned 200 to 250 million barrels of recoverable heavy oil reserves in western Missouri will most likely be found in lenticular, channel fill sandstones deposited under similar or the same conditions as the "Eastburn" sandstone and will contain similar recoverable heavy oil reserves. This heavy oil will probably be contained in sandstones of the Cherokee Group, upper and lower Bluejacket, "Eastburn", and upper and lower Warner sandstones. Younger Pennsylvanian System sandstones may contain heavy oil in the Forest City Basin, but to date the greater reported volume of heavy oil reserves are in the sandstones mentioned above. Heavy oil production in the future, if it is commercial to produce, is expected to be found in fields that are less than $10,000,000$ barrels OOIP. Annual heavy oil production in Missouri is shown in Fig. 3.7, and at its peak in early 1980, it was less than $20 \%$ of total daily Califomia heavy oil production. 


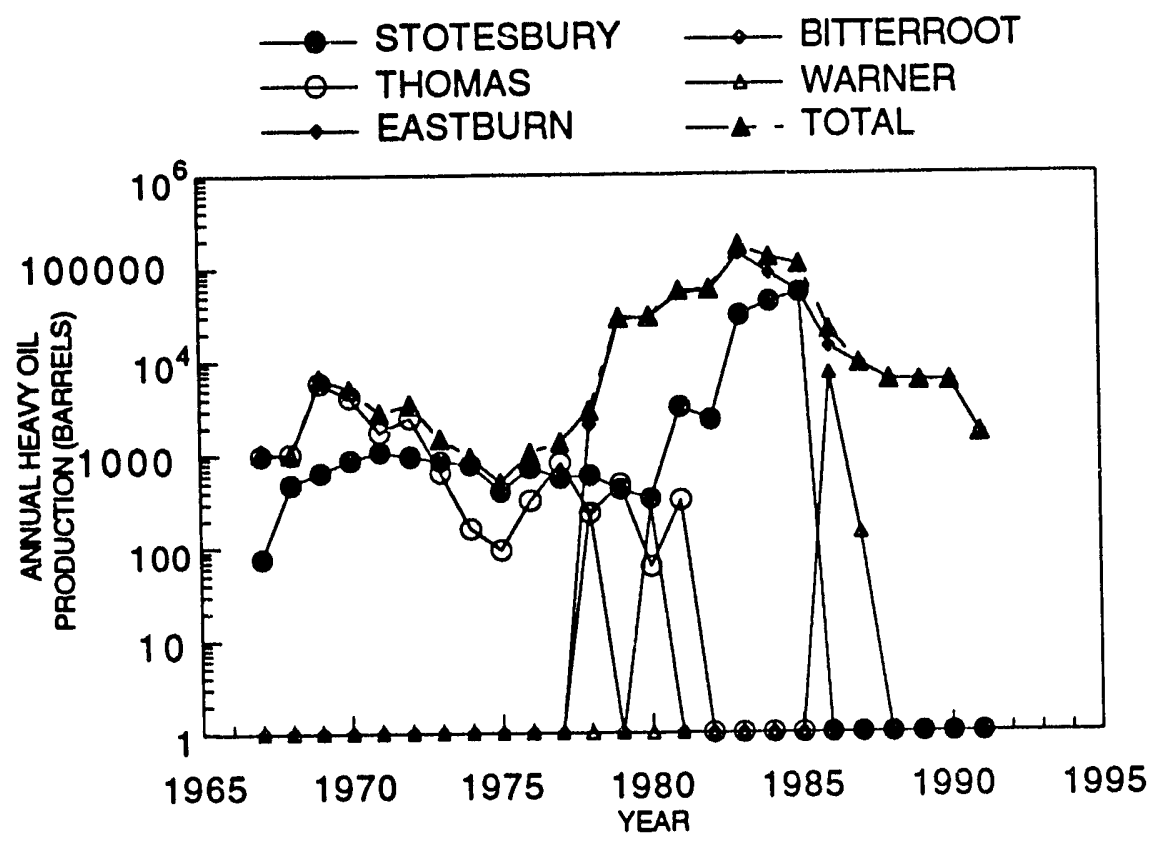

FIGURE 3.7. - Annual heavy oil production in Missouri, total and principal reservoirs.

\section{BIBLIOGRA PHY}

Aden, L. J. Clay Mineralogy and Depositional Environments of Upper Cherokee (Desmoinesian) Mudrocks, Eastern Kansas, Western Missouri, and Northeastern Oklahoma [M.S. Thesis]. University of Iowa, 1982.

Anderson, K. H. and J. S. Wells. New Thinking May Be Key To Unlocking Missouri Prospects. Oil and Gas J., v. 62; No. 50, Dec. 14, 1964, pp. 122-130.

Ball, S. M. Stratigraphy of the Douglas Group (Pennsylvanian, Virgilian) in the Northern Midcontinent Region [Ph.D.]. University of Kansas, 1964.

Boyle, D. E. McDaniel No. 6 Well located in Vernon County, Missouri. In: Mapco, Inc., Tulsa, OK, 1981.

Boyle, D. E. McDaniel No. 10 Well located in Vernon County, Missouri. In: Mapco, Inc., Tulsa, OK, 1981.

Boyle, D. E. McDaniel No. 7 Well located in Vernon County, Missouri. In: Mapco, Inc., Tulsa, OK, 1981.

Boyle, D. E. McDaniel No. 2 Well located in Vernon County, Missouri. In: Mapco, Inc., Tulsa, OK, 1981.

Boyle, D. E. McDaniel No. 14 Well located in Vernon County, Missouri. In: Mapco, Inc., Tulsa, OK, 1981.

Boyle, D. E. McDaniel No. 8 Well located in Vernon County, Missouri. In: Mapco, Inc., Tulsa, OK, 1981. 
Boyle, D. E. McDaniel No. 18 Well located in Vernon County, Missouri. In: Mapco, Inc., Tulsa, OK, 1981.

Bradshaw, D. T. Geologic Variables Influencing Production in Eastburn Field, Vernon County, Missouri; [M.S. Thesis]. Colorado State University, 1985.

Chism, J. Abandoned Oil Fields in Alabama, Florida, Illinois, Indiana, Kentucky, Michigan, Missouri, New York, Tennessee, and West Virginia. In: Department of Energy, 1983.

Deason, K. L. Studies of the Parkville, Prairie Point, and Riverside Oil and Gas Fields, Platte County, Missouri. In: Missouri Geological Survey, 1984.

Deason, K. L. and R. Bohm: Studies of West-central Missouri Oil and Gas Fields, Clay, Clinton, Caldwell, and Ray Counties, Missouri, Oil and Gas in Missouri, General Information Sheets No. 19, Revised May 1969.

Ebanks, W. J. Jr. and J. F. Weber. Development of a Shallow Heavy-oil deposit in Missouri. Oil \& Gas Journal, v. 80, Sept. 27, 1982, pp. 222-234.

Ece, O. I. Depusitional Environment, Stratigraphy, Petrology, Paleogeography, and Organic Therma! Maturation of the Desmoinesian Cyclothermic Excello Black Shale in Oklahoma, Kansas, and Missouri; [Ph.D. Dissertation], University of Tulsa, 1985.

Edwards, J. M. McDaniel No. 10-A Well located in Vernon County, Missouri. In: Mapco, Inc., Tulsa, OK, 1982.

Edwards, J. M. McDaniel No. 6-A Well located in Vernon County, Missouri. In: Mapco, Inc., Tulsa, OK, 1982.

Edwards, J. M. MC-1 Well located in Vernon County, Missouri. In: Mapco, Inc., Tulsa, OK, 1982.

Edwards, J. M. McDaniel No. B-25 Well located in Vernon County, Missouri. In: Mapco, Inc., Tulsa, OK, 1982.

Edwards, J. M. McDaniel No. B-27 Well located in Vernon County, Missouri. In: Mapco, Inc., Tulsa, OK, 1982 .

Edwards, J. M. McDaniel No. B-28 Well located in Vernon County, Missouri. In: Mapco, Inc., Tulsa, OK, 1982.

Edwards, J. M. McDaniel No. B-30 Well located in Vernon County, Missouri. In: Mapco, Inc., Tulsa, OK, 1982.

Edwards, J. M. McDaniel No. B-26 Well located in Vernon County, Missouri. In: Mapco, Inc., Tulsa, OK, 1982.

Edwards, J. M. McDaniel No. B-29 Well located in Vernon County, Missouri. In: Mapco, Inc., Tulsa, OK, 1982.

Goebel, E. D. Thermal Recovery Projects Are Increasing in Kansas, Missouri. World Oil 1966, 162(4), pp. 78-80. 
Greene, F. C. Oil and Gas Developments in Missouri in 1933-34. In: Missouri Geological Survey and Water Resources, 1935.

Johnsgard, S. K. The Fracture Pattern of North-central Kansas and Its Relation to Hydrogen Soil Gas Anomalies Over the Midcontinent Rift System [M.S. Thesis]. University of Kansas, 1988.

Johnson, W. I. and D. K. Olsen. Midcontinent Fluvial-Dominated Deltaic Depositional Environment and Their Influence on Enhanced Oil Recovery. Pres. at Petroleum Reservoir Geology in the Southern Midcontinent, Norman, OK. NIPER Report No. EPR/OP-90/18, 1990.

Kansas Geological Survey. Kansas Oil and Gas Fields. Lawrence, Kansas: Kansas Geological Survey, 1960, p. 219. (Curtis, G. R., ed.; v. 3).

Knight, R. D., E. McCracken, K. H. Anderson. Map of Selected Deep Drill Holes in Missouri. In: Rolla, Missouri: Missouri Geological Survey and Water Resources, 1970.

McCracken, E. Northeast Missouri's Oil Possibilities Improve. Oil and Gas Journal, v. 5, Jan. 3, 1955, pp. 34-35.

Mitchell, J. C. Stratigraphy and Depositional History of the Iola Limestone Upper Pennsylvanian (Missourian), Northern Midcontinent U. S. [Ph.D. Dissertation]. University of Iowa, 1981.

Netzler, B. and J. S. Wells. Oil and Gas in Missouri--by County. In: Rolla, Missouri: Missouri Geological Survey and Natural Resources, 1981.

Netzler, B. W. Studies of the Tarkio and Corning Oil Fields, Atchison and Northern Holt Counties, Missouri. In: Missouri Department of Natural Resources, 1982.

Netzler, B. W. Heavy-oil Resource Potential of Southwest Missouri. Pres. at 1989 Eastern Oil Shale Symposium, Lexington, Kentucky, University of Kentucky. Missouri Department of Natural Resources, 1989.

Netzler, B. W. Heavy-Oil Resource Potential of Southwest Missouri. In: Missouri Department of Natural Resources, Division of Geology and Land Survey, 1990.

Nielsen, M. A. Depositional and Diagenetic Study of the Exline Limestone, Pleasanton Group, Upper Pennsylvanian (Missourian) of the Northern Midcontinent; [M.S. Thesis]. University of Iowa, 1987.

Searight, W. V. Asphaltic Rocks in Western Missouri. In: Geological Survey and Water Resources, State of Missouri, 1957.

Sperry, J. S., J. F. S. Young and R. S. Poston. Field Testing of the Vapor Therm Process in the Eastburn (Cherokee) Field Vernon Co. Missouri. Proceedings of Fifth DOE Symposium on Enhanced Oil \& Gas Recovery \& Improved Drilling Technology, Tulsa, OK: The Petroleum Publishing Company, 1979: 1/1-1/16.

Stewart, G. F. Paleotectonic Investigation of the Pennsylvanian System in the United States. In: Lawrence, Kansas: Kansas Geological Survey, 1971. 
Tomes, R. J. Environmental and Diagenetic History of the "Upper" Warner Sandstone; SW Vernon County, Missouri [M.S. Thesis]. Colorado State University, 1986.

U.S. Geological Survey. Missouri Geological Survey Symposium--Mineral-Resource Potential of the Midcontinent Program and Abstracts. In: Survey MG, ed. U.S. Geoiogical Survey Circular 1043, 1989.

Wells, J. S. and K. H. Anderson. Heavy Oil in Western Missouri. The American Association of Petroleum Geologists Bulletin, v. 52, Sept. 1968, pp. 1720-1731.

Wells, J. S. Inventory of Heavy Oil in Western Missouri. In: U.S. Department of Energy, 1979. Report No. BETC-1808-1. 


\section{CHAPTER 4}

\section{OKLAHOMA HEAVY OIL OCCURRENCE AND INTEGRATED ANALYSES OF GEOLOGY AND ENHANCED OIL RECOVERY PROCESS APPLICATIONS}

\section{SUMMARY}

Shallow low permeability $(<500 \mathrm{mD})$ consolidated sandstone formations containing heavy oil exists in the northeastern counties of Oklahoma. These sandstones were deposited as meandering strearns channels and thus occur as sporadic narrow elongated fields. Reservoir rock is highly compartmentalized and fractured. Fracture alignment is generally in a northeastsouthwest direction with the secondary fractures in a perpendicular direction. Small volumes of heavy oil $(<0.3$ BOPD) are obtained by primary production. Heavy oil also occurs alorn the perimeter of all the basins in the state although the major deposits are located on the north side of the Arbuckle mountains in south-central Oklahoma. These steeply dipping high permeability $(>500 \mathrm{mD}$ ) unconsolidated or friable sands occur in fault blocks that extend from the surface to depth around the Sho-Vel-Tum field and have been produced on primary as well as by thermal methods. Primary production of heavy oil from some of these unconsolidated formations have yielded wells that average $>35$ BOPD. Thermal EOR methods (cyclic steam, steamflooding, and fireflooding) have proven that the oil can be recovered in both consolidated and unconsolidated sandstone formations but the oil production from the unconsolidated sands are the only projects reported that look both economic and environmentally acceptable.

\section{BACKGROUND}

Harrison (1979) conducted a study of heavy oil reserves in northeastern Oklahoma counties of Ottawa and Craig (Fig. 4.1). He concluded that heavy oil reserves in his study area were insignificant. The study was made on cores from 18 core holes taken for the Harrison study. The counties studied by Harrison are the logical counties to study for extremely shallow, near "grass roots," heavy oil resources, but Ottawa and Craig Counties cover an extremely small part of the Oklahoma portion of the Cherokee Platform (Basin) (Fig. 2.1). Sandstones of the Cherokee Group on the outcrop and in the subsurface in the Cherokee and Forest City Basins of Kansas and Missouri are impregnated with heavy oil. It is estimated by Ebanks, Ball, Wells and others that Cherokee Group sandstones in the Forest City and Cherokee Basins of Kansas and Missouri may contain approximately 750 million to 825 million barrels of heavy oil reserves. But these estimates are considered high because they were probably using $10^{\circ}$ to $25^{\circ}$ API gravity as the definition of heavy oil but is not stated in the report. Some, 400 million to 475 million barrels, of these heavy oil reserves are probably contained in Cherokee Group sandstones along the outcrop and immediately downdip in sandstones that are at depths that may be considered as virtually 


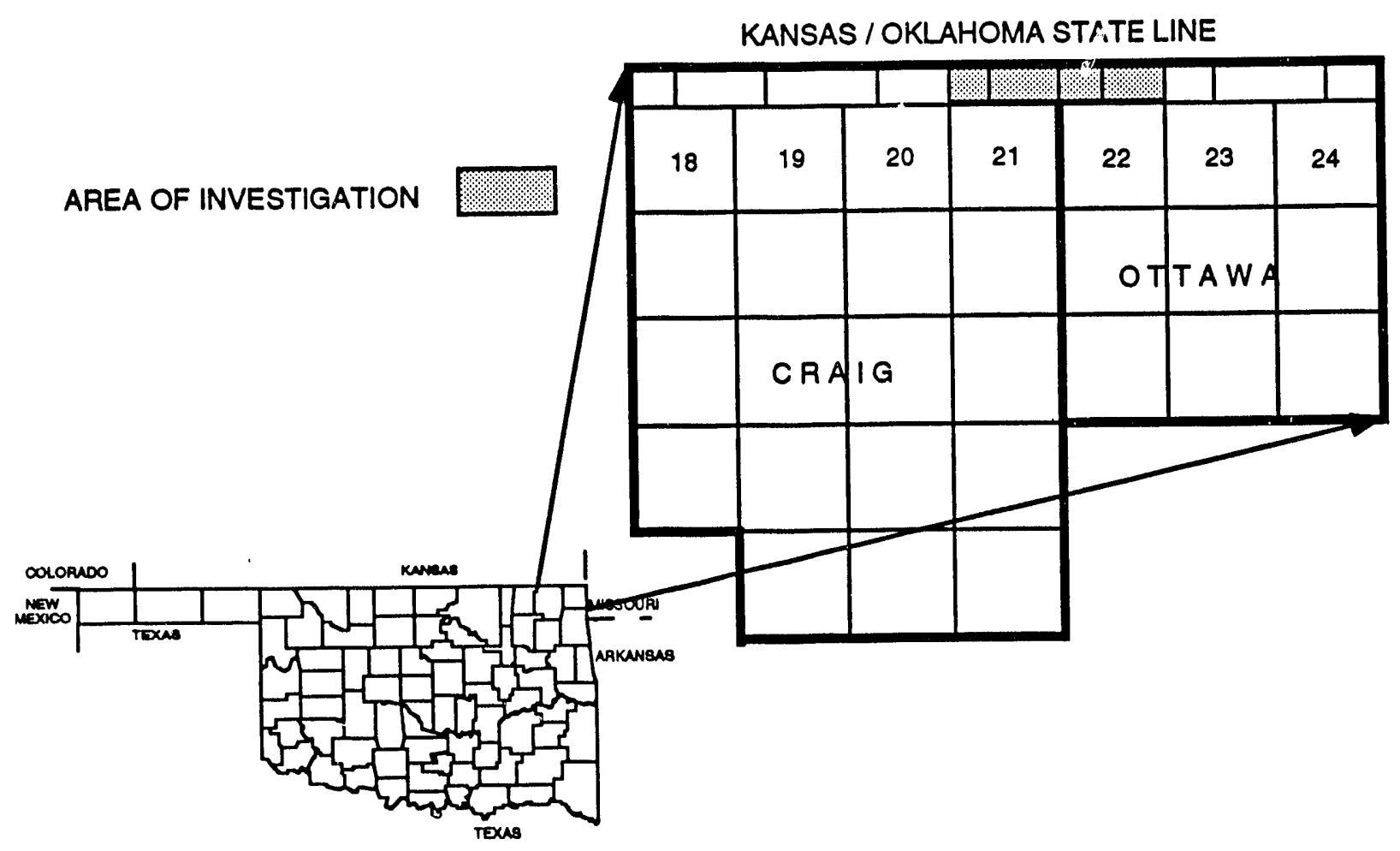

FIGURE 4.1. - Map Showing Area in Craig and Ottawa Counties which was Investigated for Heavy-Oil Potential (from Harrison, 1979).

"grass roots." Approximately 350 million barrels of these estimated heavy oil reserves in Cherokee Group sandstones of Kansas are above or below light oil production in known producing oil fields in eastern Kansas. Other heavy oil resources may exist in yet undiscovered lenticular sandstones of the Cherokee Group of Kansas and Missouri in the deeper, less than 2,000 $\mathrm{ft}$ depth, part of the Cherokee and Forest City Basins. The section of this report on Kansas covered the entire state including reservoirs in sediments that are Cambrian through Pennsylvanian in age in carbonates and sandstones. The Oklahoma part of this report will cover those parts of the state where there are known heavy oil reservoirs and that portion of northeastern Oklahoma that includes the Cherokee Basin. Since the Cherokee Group of sediments on the Cherokee Platform (Basin) of northeastern Oklahoma are the same age, in the same sedimentary basin, deposited under the same or similar conditions, have the same petrology, and have undergone the same type of diagenesis as those Cherokee Group sediments of the Cherokee Basin of Kansas and Missouri, they should be similar or the same and should contain some resources of heavy oil above, below, or near known accumulations of light oil in sandstones of the Cherokee Group on the Cherokee Platform of northeastern Oklahoma. The Cherokee Platform petroleum province of northeastern Oklahoma has produced 1.5 billion barrels of oil (Harrison, 1979), with no mention made 
whether any of this oil production was heavy oil. In discussions with some Oklahoma independent oil producers, occurrence of heavy oil bearing sands above or below known accumulations of light oil have been mentioned.

South Central Oklahoma has estimated proven heavy oil reserves of $>42$ million barrels in the South Sulphur and South Woodford areas in Carter and Murray counties. Reserves in these areas were first estimated to be 800 million barrels but revised downward to the Fig. 4.1 by Harrison (1984). These reserves are found primarily in Ordovician, Simpson Group, Oil Creek Sandstone and to a lesser extent in younger formations of Ordovician, Silurian-Devonian, Devonian, Mississippian, and Pennsylvanian periods (Williams, 1983). These resources are found on the outcrop and shallow subsurface in these areas. On the outcrop, asphaltic sandstone has been mined for use as road paving material, but failure occurs rapidly with weathering of the calcareous cement in the sandstone and poor quality of the asphalt.

The fourth Deese sand in the Sho-Vel-Tum field is a heavy oil reservoir. Mobil Producing U.S. Inc. has been conducting a successful cyclic steam heavy oil project in the Cox Penn area of the field since 1986. This poorly consolidated to unconsolidated fluvial-dominated deltaic, Pennsylvanian Period, Desmoinesian Series, Cherokee Group sand has not reported having depositional compartmentalization problems that other Midcontinent sandstones of this group. Cyclic steam with gravity drainage in the steeply dipping $\left(40^{\circ}\right)$ sand is the primary producing mechanism. Heavy oil production has been increased from 2 BOPD to a peak of 150 BOPD per steam cycle (Chiou, 1989).

\section{GEOLOGY}

\section{SOUTH SULPHUR ASPHALT DEPOSITS}

The South Sulphur asphalt (heavy oil) deposits are located in Murray County, Oklahoma on the northwest flank of the Arbuckle Mountains (Chapter 2, Figs. 2.1 and 4.2). The Reagan Fault, a major left wrench fault, lies 2.5 miles to the south (Fig. 4.3). The Mill Creek Fault defines the northern limit of the area. These two major faults delineate the Mill Creek Syncline (Williams, 1983).

\section{ORDOVICIAN PERIOD}

\section{Arbuckle Formation}

The Arbuckle Formation is the oldest encountered in the South Sulphur area (Fig. 4.4). It is found as shallow as $400 \mathrm{ft}$ to $500 \mathrm{ft}$ north and west of the Prindle Creek fault. Since the Arbuckle Formation was not penetrated through to the base of the formation, no thickness is known for the South Sulphur area. It is composed of limestone and dolomite with limestone interbedded with shale and sandstone layers as the dominant lithology. The limestone is finely crystalline with a 


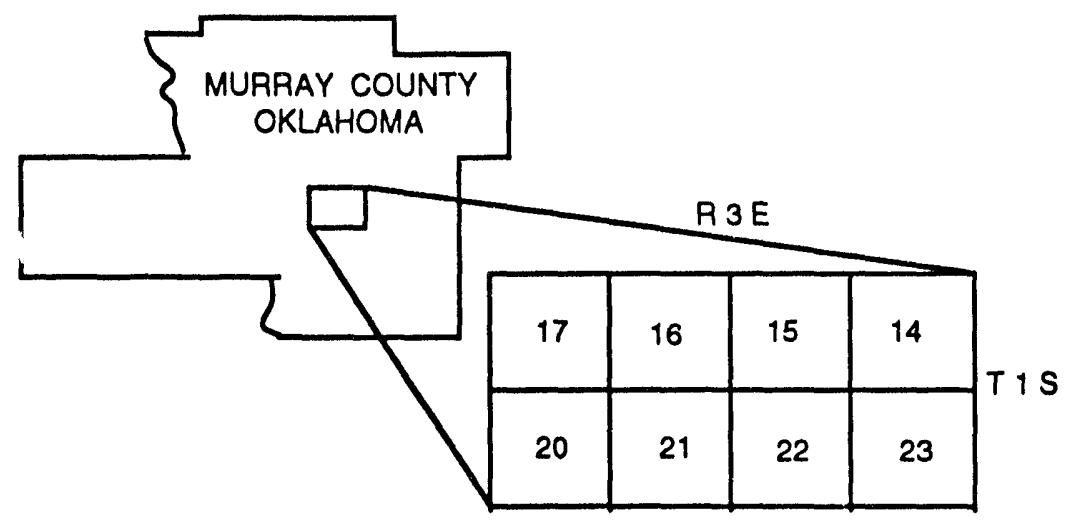

FIGURE 4.2. - Location of Study Area (from Williams, 1983).

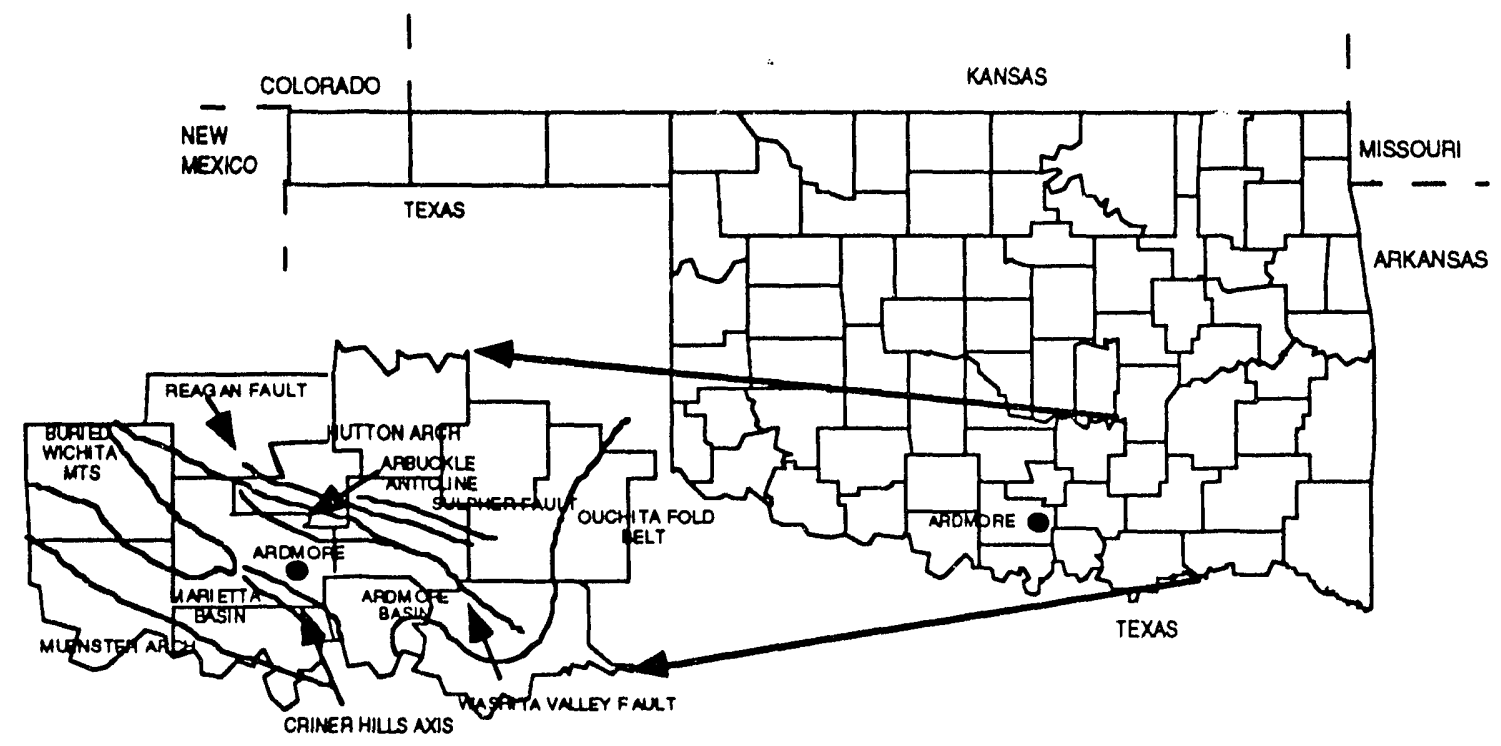

FIGURE 4.3. - Southern Oklahoma Fold Belt Showing Structural Provinces (from Johnson, 1989). 


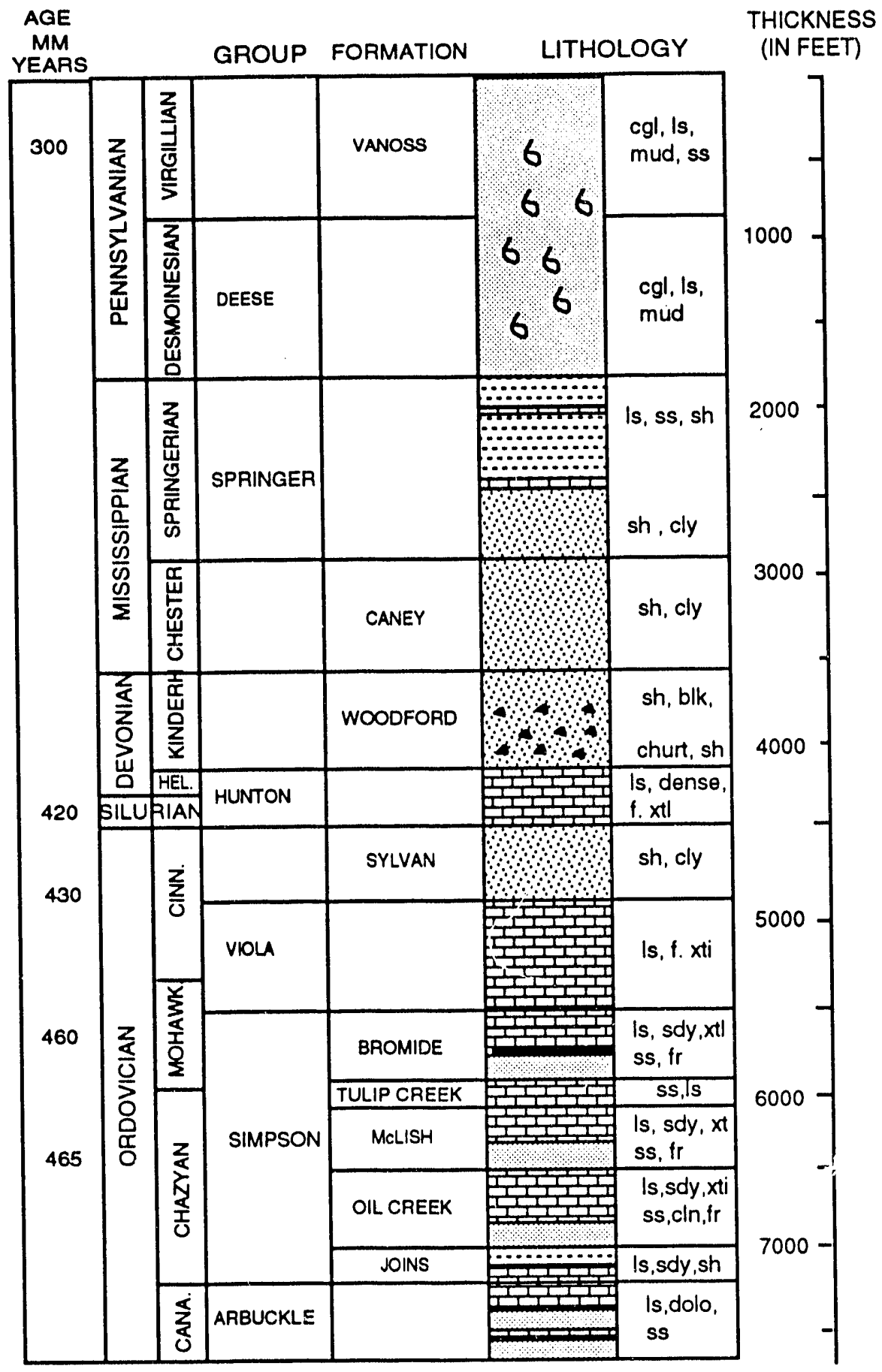

FIGURE 4.4. - Stratigraphic Section, South Sulphur Area, Murray Co., Oklahoma (from Williams, 1983). 
medium gray color, interbedded with dark gray to black or tan sandy shale beds that are commonly fossiliferous with traces of bitumen. There are 2 sand layers about $25 \mathrm{ft}$ thick, $60 \mathrm{ft}$ below the top of the Arbuckle. These zones may be present and contain no bitumen (Williams, 1983).

\section{Simpson Group \\ Joins Formation}

The Joins Formation is the basal unit of the Simpson Group (Fig. 4.4). It is limestone with thin interbedded layers of sand and shale. The Joins contains the only significant shale beds in the Simpson group. The shale is vivid green, fissile, calcareous and often pyretic. Some of the thin sand layers have slight bitumen saturation. The limestone is pale green, light gray, off-white, dark green or dark gray, slightly fossiliferous, finely crystalline, sandy becoming denser and less sandy with depth. All of the core holes in the South Sulphur area had traces of bitumen with some having slight to moderate saturation. The Joins is 250 feet thick in this area (Williams, 1983).

\section{Oil Creek Formation}

The Oil Creek Formation is made up of a basal sandstone and an upper limestone unit (Fig. 4.4). The sandstone is off white or tan, ranging to light to medium gray, fine- to very-finegrained, quartzose, well sorted, rounded to subrounded, often frosted and/or pitted with limonite concretions. It is friable, loosely bound sandstone with carbonate cement or clay minerals. The Oil Creek sandstone contains most of the bitumen in the South Sulphur area. Veins and seams of bitumen impregnated sandstone may be seen in mining pits along the outcrop. The sandstone is $150 \mathrm{ft}$ thick in this area (Williams, 1983).

The Oil Creek limestone can be divided into upper and lower units. The upper limestone is tan to light gray, thin-bedded, sandy, finely crystalline, with some shale. The lower limestone is tan to yellow-brown, coarsely crystalline, fossiliferous, with traces to slight saturation of bitumen. Average thickness of the Oil Creek limestone is $25 \mathrm{C} \mathrm{ft}$ (Williams, 1983)

\section{McLish Formation}

The McLish Formation has a lower sandstone and an upper limestone similar to the Oil Creek Formation (Fig. 4.4). The sandstone is friable, with carbonate cement, tan, fine-to mediumgrained, dominantly rounded, often frosted, with moderate saturation of bitumen on the outcrop. Average thickness of the sandstone is $150 \mathrm{ft}$. The limestone has an upper member that is coarsely crystalline, tan to gray, and sandy. The lower limestone member is tan or green, dense to finely crystalline, with calcite inclusions, commonly referred to as "birdseye" texture, with traces of birumen. Average thickness of the limestone is $250 \mathrm{ft}$ (Williams, 1983).

\section{Tulip Creek Formation}

The Tulip Creek Formation is the thinnest of the Simpson units in the South Sulphur area (Fig. 4.4). It has been mapped as part of the overlying Bromide Formation because of its 
thickness. The Tulip Creek sandstone is known as the "Wilcox" sandstone by petroleum geologists in Oklahoma. It is tan, fine-grained, friable, sandstone averaging $50 \mathrm{ft}$ thick with traces

of bitumen. The limestone is light gray or tan, bedded, dense to finely crystalline with an average thickness of $50 \mathrm{ft}$ (Williams, 1983).

\section{Bromide Formation}

The basal unit of the Bromide Formation is sandstone (Fig. 4.4). It is light tan to white, fine- to medium-grained, sub-angular to sub-rounded, friable to semi-consolidated with carbonate cement sandstone with no bitumen staining, having an average thickness of $130 \mathrm{ft}$. The upper unit is thin, dense, gray or brown, sandy limestone with calcite inclusion. The lower limestone unit is light tan to light gray, coarsely crystalline, fossiliferous, and platy. The Bromide liınestone has an average thickness of $250 \mathrm{ft}$ (Williams, 1983).

\section{Viola Group}

\section{Viola Formation}

The Viola Formation is divided into two units in most areas, but in the South Sulphur area the upper Fernvale unit is not present (Fig. 4.4). At the South Sulphur area the Viola is gray, finely crystalline, bedded limestone containing no sand with moderate bitumen saturation. It is $600 \mathrm{ft}$ thick in this area (Williams, 1983).

\section{Unnamed Group}

\section{Sylvan Formation}

The Sylvan Formation, $250 \mathrm{ft}$ in thickness, is a green to gray, slightly calcareous, clay shale (Fig. 4.4). It varies in thickness due to flowage in the soft shale because of deformation (Williams, 1983).

\section{SILURIAN - DEVONIAN PERIODS}

\section{Hunton Group}

\section{Hunton Formation}

The Hunton Formation is brown to tan, dense to finely crystalline, fossiliferous limestone with traces of bitumen throughout. It is $250 \mathrm{ft}$ thick (Fig. 4.4) (Williams, 1983).

\section{DEVONIAN PERIOD}

\section{Unnamed Group}

\section{Woodford Formation}

The Woodford Formation is a single unit of brown to tan, dense to finely crystalline, fossiliferous limestone with traces of bitumen in the South Sulphur area (Fig. 4.4). It is 250 feet thick (Williams 1983). 


\section{MISSISSIPPIAN PERIOD}

\section{Unnamed Group}

\section{Caney Formation}

The Caney Formation is dark brown or gray, phosphatic, clay shale. It has a thickness of approximately $600 \mathrm{ft}$ in the South Sulphur area (Fig. 4.4) (Williams, 1983).

\section{PENNSYLVANIAN PERIOD \\ Deese Group \\ Deese Formation}

The Deese in the South Sulphur area is a mud supported limestone conglomerate (Fig. 4.4). Pebbles and cobbles in the Deese erosional fragments are from the Hunton through upper Arbuckle formations. It has a thickness of approximately $1,100 \mathrm{ft}$ in the southern part of the South Sulphur area. In the South Sulphur area it occurs as isolated tiocks, making it difficult to measure the thickness. It overlies older units unconformably (Williams, 1983).

\section{Unnamed Group \\ Vanoss Formation}

The Vanoss Formation is the youngest Pennsylvanian conglomerate in the South Sulphur area (Fig. 4.4). It is mud supported conglomerate with limestone and Precambrian granite and feldspar cobbles and pebbles with interbedded sandstones. The conglomerate is ofter saturated with bitumen where it is in contact with bitumen saturated sandstone. It has a thickness if $1,100 \mathrm{ft}$. It overlies older units unconformably.

\section{SOUTH-CENTRAL OKLAHOMA}

Harrison (1982) sited four locations in Carter and Murray Counties, Oklahoma with heavy oil potential. These sites were evaluated by drilling core holes. The South Sulphur areas, discussed above, and the Dougherty area were considered to hold the most potential as heavy oil producing areas on or near the surface. Jordan (1964) reported fifty-seven localities in Carter and Murray counties where tar, oil and asphalt either (a) occur at the surface or (b) is produced from depths of $500 \mathrm{ft}$ or less. Heavy oil impregnated rock in the areas sited by Harrison (1982) have the same geology as discussed above for the South Sulphur area studied by Williams (1983). The Interstate Oil Compact Commission (IOCC) reports occurrence of heavy oil production in several counties of South-Central Gklahoma at depths from approximately $600 \mathrm{ft}$ to $7,100 \mathrm{ft}$. Geology of most producing zones in the IOCC area have been discussed above. Formations that are reservoir rock for heavy oil in South-Central Oklahoma that were not described above are discussed in this section. 


\section{MISSISSIPPIAN PERIOD}

\section{Springeran Series}

\section{Springer Group}

The Springer Group is a series of sandstone zones separated by shale lenses (Fig. 4.4). The shale is micaceous, gray to gray-black with a splintery fracture. The Aldridge, the youngest Springer sandstone, is white, glassy, medium-grained sandstone. Below the Aldridge is the Humphreys, a $50 \mathrm{ft}$ to $100 \mathrm{ft}$, calcareous, fine-to medium-grained sandstone interbedded with shale with traces of oolitic material. The third sandstone is the Sims which consists of two to four members. The Sims is oolitic in the top $5 \mathrm{ft}$ to $10 \mathrm{ft}$ and silty, calcareous, fine- to medium-grained sandstone in the remainder of this zone. The lowest Springer sandstone zone is the Goodwin. It is fine-grained, well-cemented sandstone with calcareous cement (Vanbuskirk, 1960).

\section{PENNSYLVANIAN PERIOD}

\section{Desmoinesian Series}

\section{Deese Group}

The Deese unconformably overlies Springer Group sediments (Fig. 4.5). An oolitic limestone is at the base of the Deese. It is made up mainly of shale with some well developed sandstones and a few thin limestone streaks. The sandstones are fine-grained and slightly calcareous. The upper Fusulinid zone, about $200 \mathrm{ft}$ below the top of the Deese, is $100 \mathrm{ft}$ to $150 \mathrm{ft}$ of white, fine-grained, porous to glassy, calcareous sandstone interbedded with platy gray shales. The lower Fusulinid zone, about $200 \mathrm{ft}$ to $250 \mathrm{ft}$ below the upper Fusulinid sandstone, is thin, fine-grained, calcareous sandstone lenses separated by gray shale streaks. The Tussy, $17 \mathrm{ft}$ to $225 \mathrm{ft}$ thick, is fine-grained, calcareous, shaley sandstones separated by gray shale layers and a few thin finely crystalline limestone streaks and underlies the Fusulinid zones. The Tussy limestone is tan to white and finely crystalline. The Edwards, about $100 \mathrm{ft}$ below the Tussy, is tight, fine-grained, calcareous sandstone with heavy black oil stain. The Williams is a finegrained, silty, calcareous sandstone that is the middle member of the lower Deese Group. The Pickens sandstone, $25 \mathrm{ft}$ thick is an important oil producing member of the Deese Group. Pickens sandstone is fine-grained, shaley and becomes calcareous near the base (Vanbuskirk, 1960).

\section{Missourian Series}

\section{Hoxbar Group}

The Hoxbar consists of light to dark gray, micaceous shales, thin, sometimes arenaceous and chalky limestones, with intermittent chert and arkose (Fig. 4.5). The two important mappable formations in this group are the County Line limestone and the Oolitic limestone. The County Line, approximately $600 \mathrm{ft}$ thick, is medium crystalline, porous, white to tan limestone. The 


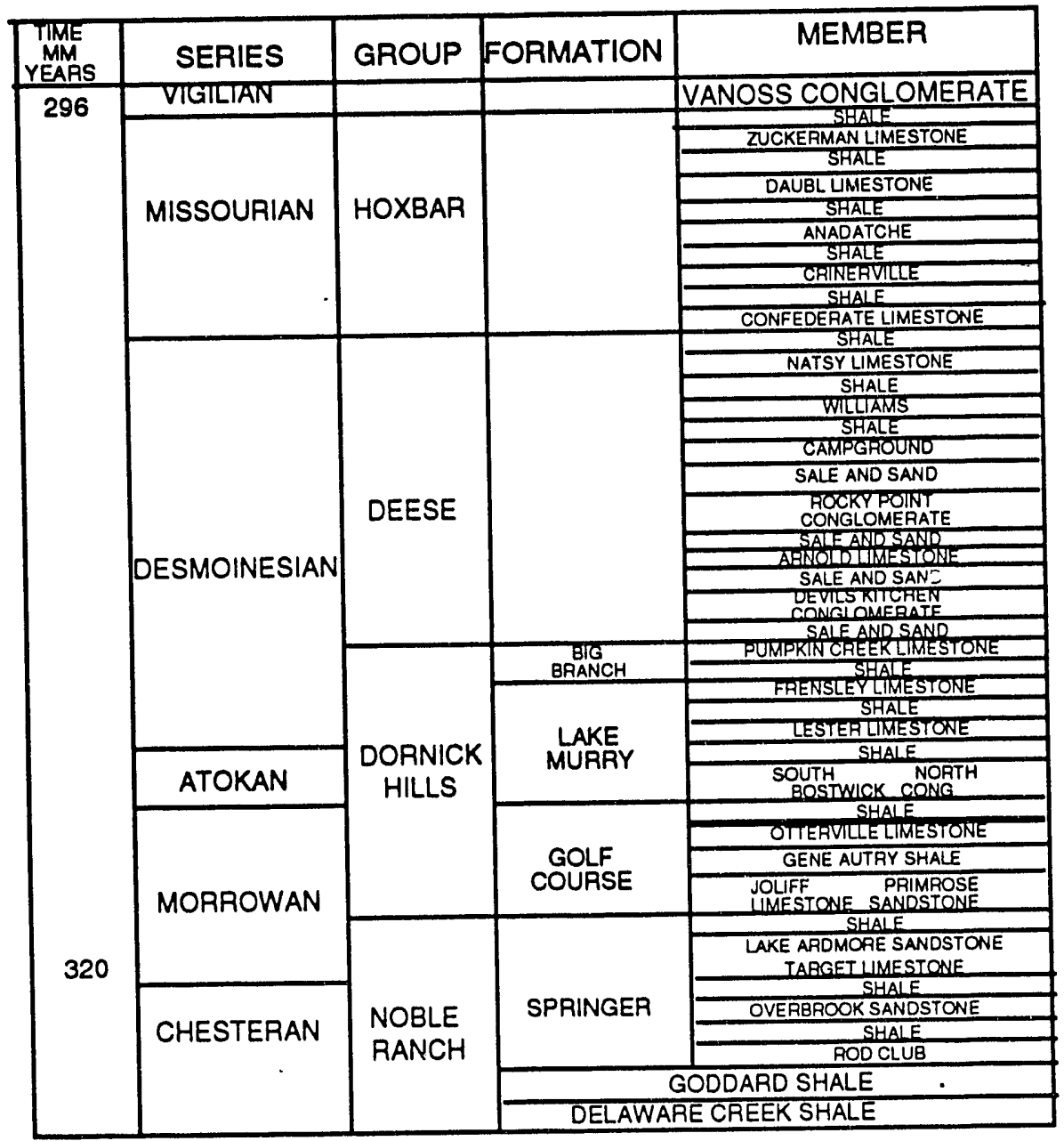

FIGURE 4.5. - Columnar Section of Outcropping Pennsylvanian Strata in the Ardmore Basin (from Johnson, 1989). 


\begin{tabular}{|c|c|c|c|c|c|c|}
\hline \multirow{3}{*}{$\begin{array}{l}\text { TIME } \\
\text { MM } \\
\text { YEARS }\end{array}$} & \multirow{3}{*}{ PERIOD } & \multirow{3}{*}{ SERIES } & \multicolumn{4}{|c|}{ FORMATION OR GROUP } \\
\hline & & & HOUGOTON & ANADARKC & BASIN & \\
\hline & & & $\begin{array}{l}\text { EMBAAMENI } \\
\text { TOUTCAOPS AND } \\
\text { SUBSURFACE) }\end{array}$ & $\begin{array}{l}\text { CENTRAL ANDWESTEAN } \\
\text { PARTS (OUTCROPS AND } \\
\text { SUSUAFACE) }\end{array}$ & $\begin{array}{l}\text { EASTEAN } \\
\text { PARTS }\end{array}$ & $\begin{array}{l}\text { CENTPAL } \\
\text { ROPS ) }\end{array}$ \\
\hline \multirow{8}{*}{255} & \multirow{10}{*}{ PERMIAN } & OCHOAN & A & \begin{tabular}{|c|} 
ELK CITY SANOSTONE \\
DOSEY SHALE \\
ALIBATES BED \\
\end{tabular} & 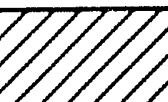 & $1 / 1 / 1$ \\
\hline & & \multirow{6}{*}{ GUADALUPIAN } & CLOUD CHIEF & CLOUD CHIEF FORMATION & 2 CLOUD & \\
\hline & & & WHITEHOASE & $\begin{array}{l}\text { FUSH SPPRINGS } \\
\text { FORMATION }\end{array}$ & $\begin{array}{l}\text { RUSH SPPINGS } \\
\text { EORMAION }\end{array}$ & WHITE \\
\hline & & & FORMATION & MARIOW FOPMATION & MAAIOW & GROUP \\
\hline & & & $\begin{array}{l}\text { NIPPEWALIA } \\
\text { GROUP }\end{array}$ & \begin{tabular}{|l} 
YELTCON DOG CALEF \\
SALT \\
SHALE
\end{tabular} & $\begin{array}{l}\text { DOG CAEEK } \\
\text { SHALE } \\
\end{array}$ & \\
\hline & & & & $\begin{array}{l}\text { FLOWERPOT } \\
\text { SHALE }\end{array}$ & $\begin{array}{l}\text { CHIIKASHA } \\
\text { FORMATION }\end{array}$ & LAENO \\
\hline & & & & $\begin{array}{l}\text { GLOAIETA } \\
\text { SANDSTONA }\end{array}$ & $\begin{array}{l}\text { DUVNCAN } \\
\text { SANOSTONE }\end{array}$ & \\
\hline & & \multirow[t]{2}{*}{ LEONARDIAN } & \multirow{2}{*}{$\begin{array}{l}\text { SUMNER } \\
\text { GAOUP }\end{array}$} & \begin{tabular}{|l|} 
HERNESSSEY SHALE \\
CIMARRON EVAPOAITES \\
\end{tabular} & \multirow{2}{*}{\multicolumn{2}{|c|}{$\begin{array}{l}\text { HENNESSEY GAREE } \\
\text { GROUP } \\
\text { WELLINGTON FORMATION } \\
\end{array}$}} \\
\hline \multirow{2}{*}{275} & & & & $\begin{array}{l}\text { MENNESSEY SHALE } \\
\text { WELLING TON EVAPORTIE }\end{array}$ & & \\
\hline & & WOLFCAMPIAN & $\begin{array}{l}\text { CHASE GROUP } \\
\text { COUSLL GROVE } \\
\text { ADMIAE GROUP }\end{array}$ & $\begin{array}{l}\text { CHASE GAOUP } \\
\text { CONGLL GROVE } \\
\text { ADIRE GROP }\end{array}$ & \multirow{2}{*}{\multicolumn{2}{|c|}{$\begin{array}{c}\text { GRANITE WASH } \\
\text { ERODED FROM } \\
\text { WHICHBITA-AMARILLO } \\
\text { UPLIFT }\end{array}$}} \\
\hline \multirow{4}{*}{290} & \multirow{4}{*}{ PENNSYLVANIAN } & VIGILIAN & $\begin{array}{l}\text { WABAUNSEE GROUP } \\
\text { SHAWNEE GROUP } \\
\text { DOUGLAS GROUP }\end{array}$ & $\begin{array}{l}\text { WABAUNSEE GROUP } \\
\text { SHAWNEE GROUP } \\
\text { DOUGLAS GROUP }\end{array}$ & & \\
\hline & & MISSOURIAN & $\begin{array}{l}\text { LANSING GROUP } \\
\text { KANSAS CITY GROUP }\end{array}$ & OCHELAT OOP & & \\
\hline & & DESMOINESIAN & $\begin{array}{l}\text { PLEASANTON GAOUP } \\
\text { MARMATON GROUP }\end{array}$ & MAFMATONGROUP & & \\
\hline & & ATOKAN & \begin{tabular}{|c|} 
CHEROKEE GROUP \\
TOKA GROUP
\end{tabular} & $\begin{array}{l}\text { CHEROKEE GROUP } \\
\text { ATOKA GROUP }\end{array}$ & & \\
\hline \multirow{3}{*}{$\begin{array}{l}320 \\
330\end{array}$} & \multirow{3}{*}{ MISSISSIPPIAN } & MORROWAN & MORROW GROUP & MOAROW GROUP & & \\
\hline & & & 7777 & SPINGF & & \\
\hline & & CHESTERAN & & CHESTE & & \\
\hline
\end{tabular}

FIGURE 4.6. - Stratigraphic Column of Pennsylvanian and Permian Strata in the Anadarko Basin and the Hugoton Embayment (modified from Johnson, 1978; and Hills and Kotlowski, 1983).

Oolitic limestone, at the base of the Hoxbar, is microcrystalline, cream colored limestone (Vanbuskirk, 1960).

\section{PERMIAN PERIOD}

\section{Leonardian and Wolfcampian Series}

\section{Pontotoc Group}

Permian sediments overlie the Hoxbar Group unconformably (Fig. 4.6). The Leonardian and Wolfcampian series are sequences of red and gray shales and sandstones. They are fine- to medium-grained sandstones and conglomerates interbedded with gray and red to redish-brown shales. The basal Pontotoc Group appears to be arkosic and cherty (Vanbuskirk, 1960). 


\section{SOUTHEASTERN OKLAHOMA}

The discovery of $28.6^{\circ}$ API gravity oil in section 5, T. 8 S., R. 23 E., McCurtain County, Oklahoma on the W. O. Harmon farm was reported in 1953 (Figs. 4.7 through 4.9). This discovery was significant at the time because it was the first oil in the State of Oklahoma discovered and produced from a sandstone of the Paluxy Formation, Trinity Group, Comanche Series, lower Cretaceous Period. The gravity of the oil in 1953 is very significant because oil taken from oil storage tanks on this lease for an Oklahoma Geological Survey study for the Ouachita Mountains by Weber (1990) was found and reported to be $20^{\circ}-23^{\circ}$ API gravity "heavy oil". This highlights problems of sampling, loss of light ends with time, and various definitions of heavy oil. Asphalt occurs in an exposure of Paluxy sandstone that is 25 feet thick in Section 20, T. 7 S., R. 24 E., on the south side of the Little River for a distance of about one-half mile (Fig. 4.10). In another outcrop exposure of the Paluxy sandstone that is about 10 feet in thickness in the SE/4 of section 22, T. 6 S., R. 24 E. in a area of about one-half acre overlain by 5 feet of shale, which in turn is overlain by the Goodland limestone (Fig. 4.10). Paluxy sandstones produce oil and/or gas, light and heavy, in Louisiana, Mississippi, and Texas (Davis, 1953).

Along the outcrop Paluxy sand is dark reddish brown to light gray with some white lenses, well-rounded, well, sorted, cross-bedded, unconsolidated and friable. The color is due to oxidation of iron nodules of pyrite, marcasite, and limonite. Clay is interbedded with the sand. The Paluxy is overlain by a clay bed, $5 \mathrm{ft}$ to $20 \mathrm{ft}$ thick, identified as the Walnut clay of the Fredricksburg Group (Davis, 1953).

\section{CHEROKEE PLATFORM (BASIN) - NORTHEASTERN OKLAHOMA MIDDLE PENNSYLVANIAN PERIOD \\ Cherokee Group}

Middle Pennsylvanian sediments of the Cherokee group in the Northeastern Oklahoma portion of the Cherokee Platform (Basin) were deposited in a fluvial deltaic environment as were sediments of this group in Southwestern Missouri and Eastern Kansas in the Cherokee and Forest City Basins (Chapter 2, Figs. 2.1 and 4.11). The difference in Northeastern Oklahoma is the naming of the various Cherokee sands, otherwise the stratigraphy is same. Therefore, the stratigraphy will not be discussed again in the Oklahoma report. Taneha (Tucker) and Burgess sandstones in the Oklahoma portion of the Cherokee Basin are probably stratigraphic and depositional equivalents to the Warner sandstone intervals of Kansas and Missouri in the Cherokee and Forest City Basins. In the references checked for this portion of this report no references were found about the occurrence of heavy oil in sandstones of Cherokee age. In the Oklahoma portion 


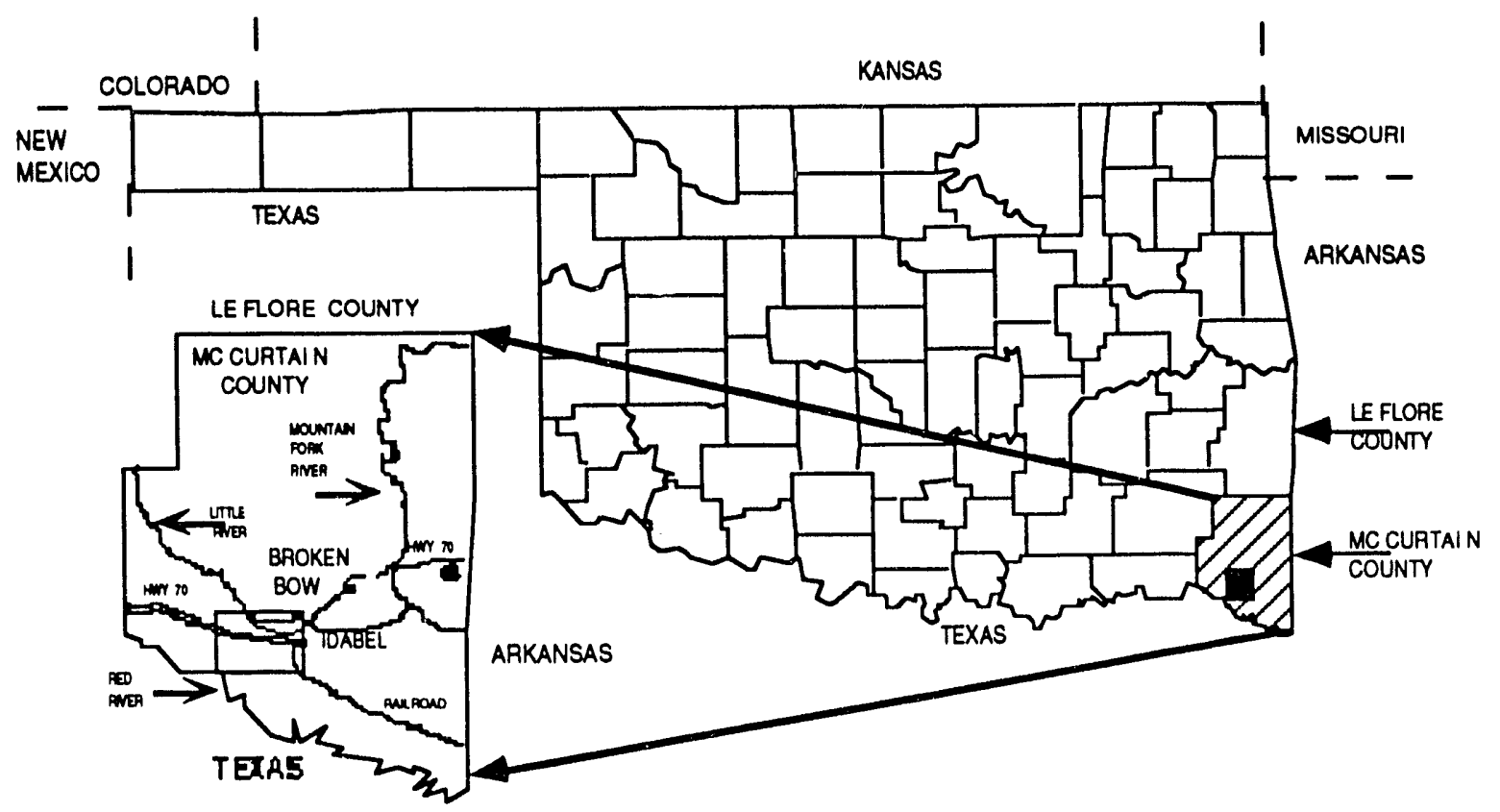

FIGURE 4.7. - Index Map of Oklahoma Showing Location of McCurtain County (ruled pattern) and of the Area Covered by this Report (solid black). Inset Map Shows Principal Features in this County (from Davis, 1953).

\begin{tabular}{|c|c|c|c|c|c|c|}
\hline $\begin{array}{l}\text { TIME } \\
\text { MM } \\
\text { YEARS }\end{array}$ & SYSTEM & SERIES & GROUP & FORMATION & LITHOLOGY & $\begin{array}{c}\text { THICKNESS } \\
\text { (FEET) }\end{array}$ \\
\hline & QUATERNARY & $\begin{array}{c}\text { RECENT } \\
\text { PLEISTOCENE }\end{array}$ & & $\begin{array}{l}\text { ALUVIUM } \\
\text { AND } \\
\text { TERRACE } \\
\text { DEPOSITS }\end{array}$ & ? & 0.60 \\
\hline & & & NCONFORM & TYY & & \\
\hline 72 & CRETACEOUS & GULF & & {$\left[\begin{array}{c}\text { TOKIO } \\
\text { FORMATION } \\
\begin{array}{c}\text { WOODBINE } \\
\text { FORMATION }\end{array}\end{array}\right.$} & $\begin{array}{l}r=r=7= \\
\bar{F}=-\frac{7}{r} \\
r \cdot r\end{array}$ & $\begin{array}{l}0-102 \\
0.70\end{array}$ \\
\hline & & & NCONFORM & TYY & & \\
\hline & & $r \quad x$ & WASHITA & UNDIFFEREI & fiated & $105-277$ \\
\hline & & COMANCHE & FREDERICKSBUPG & $\begin{array}{l}\text { GOODLAND } \\
\text { LIMESTONE }\end{array}$ & 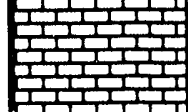 & $48-67$ \\
\hline & CRETACEOUS & & TPINITY & PALUXY SAND & & \\
\hline & & & & $\begin{array}{l}\text { DEOUEEN } \\
\text { LMESTONE }\end{array}$ & 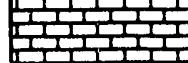 & $880+$ \\
\hline & & & & HOLLY CREEK & & \\
\hline
\end{tabular}

FIGURE 4.8.- Generalized Section of Cretaceous and Younger Rocks in McCurtain County, Oklahoma (modified from Davis, 1953). 


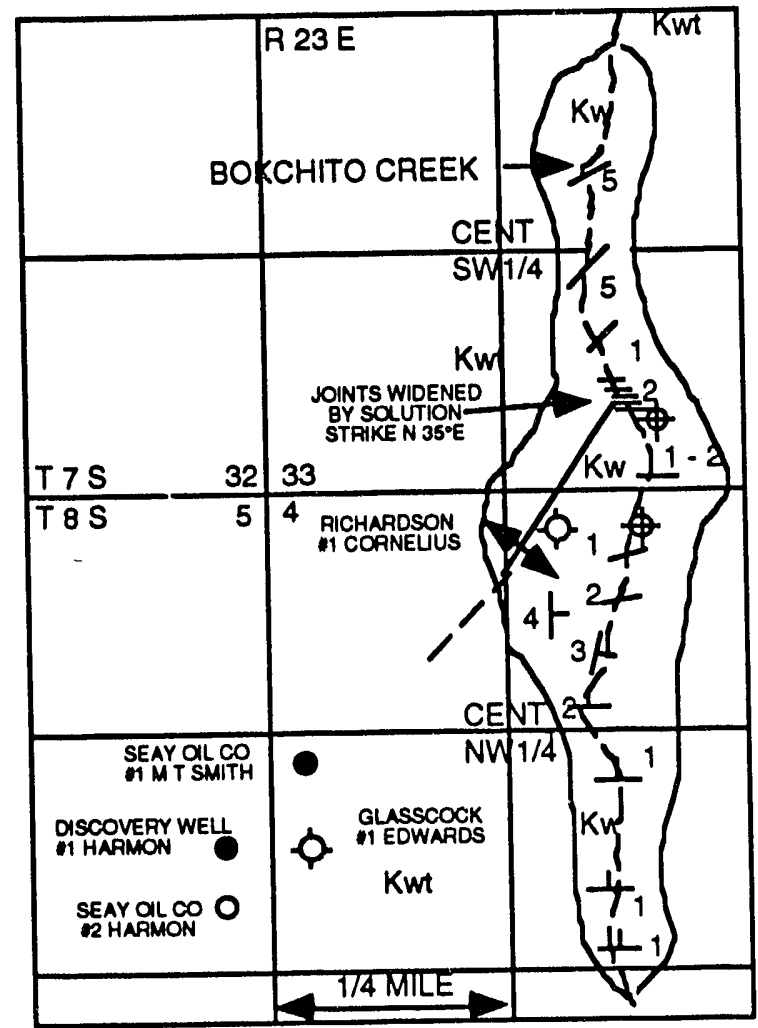

FIGURE 4.9. - Structural Detail at Inlier of Washita Group along Bokchito Creek. Kwt, Woodbine Formation; Kw, Washita Group (from Davis, 1953).
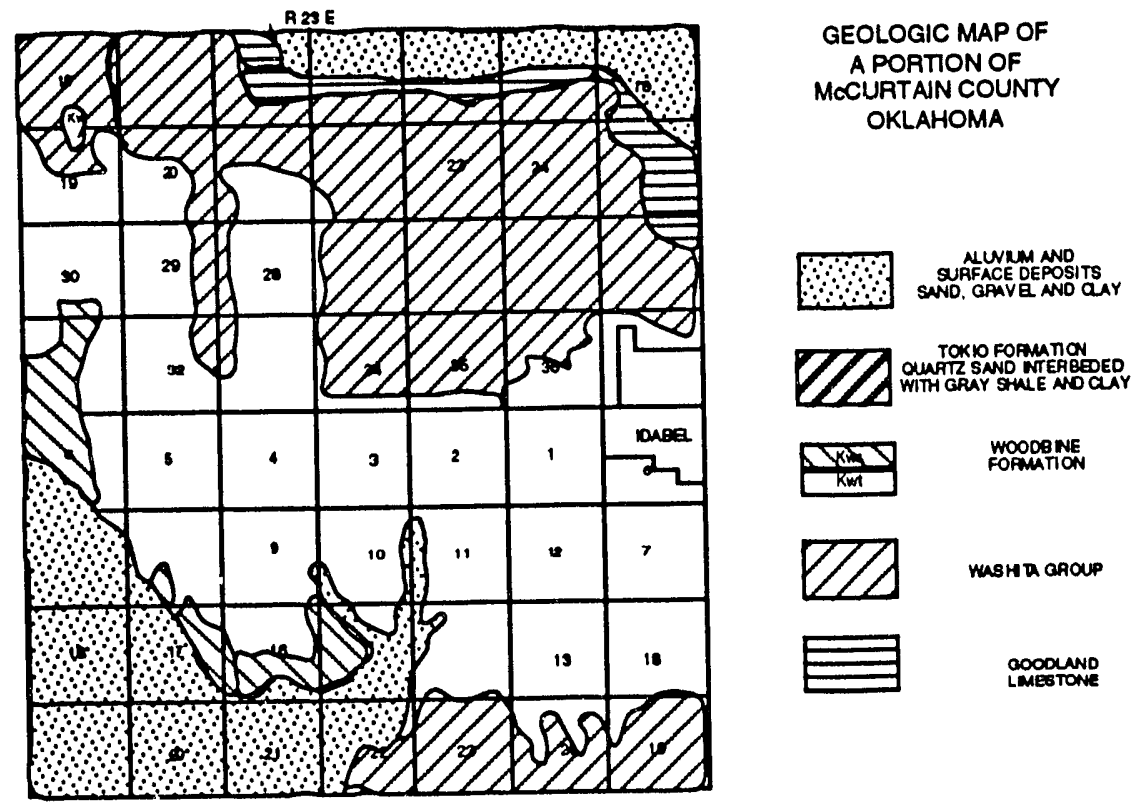

FIGURE 4.10. - Geologic Map of a Portion of McCurtain County, Oklahoma (from Davis, 1953. 


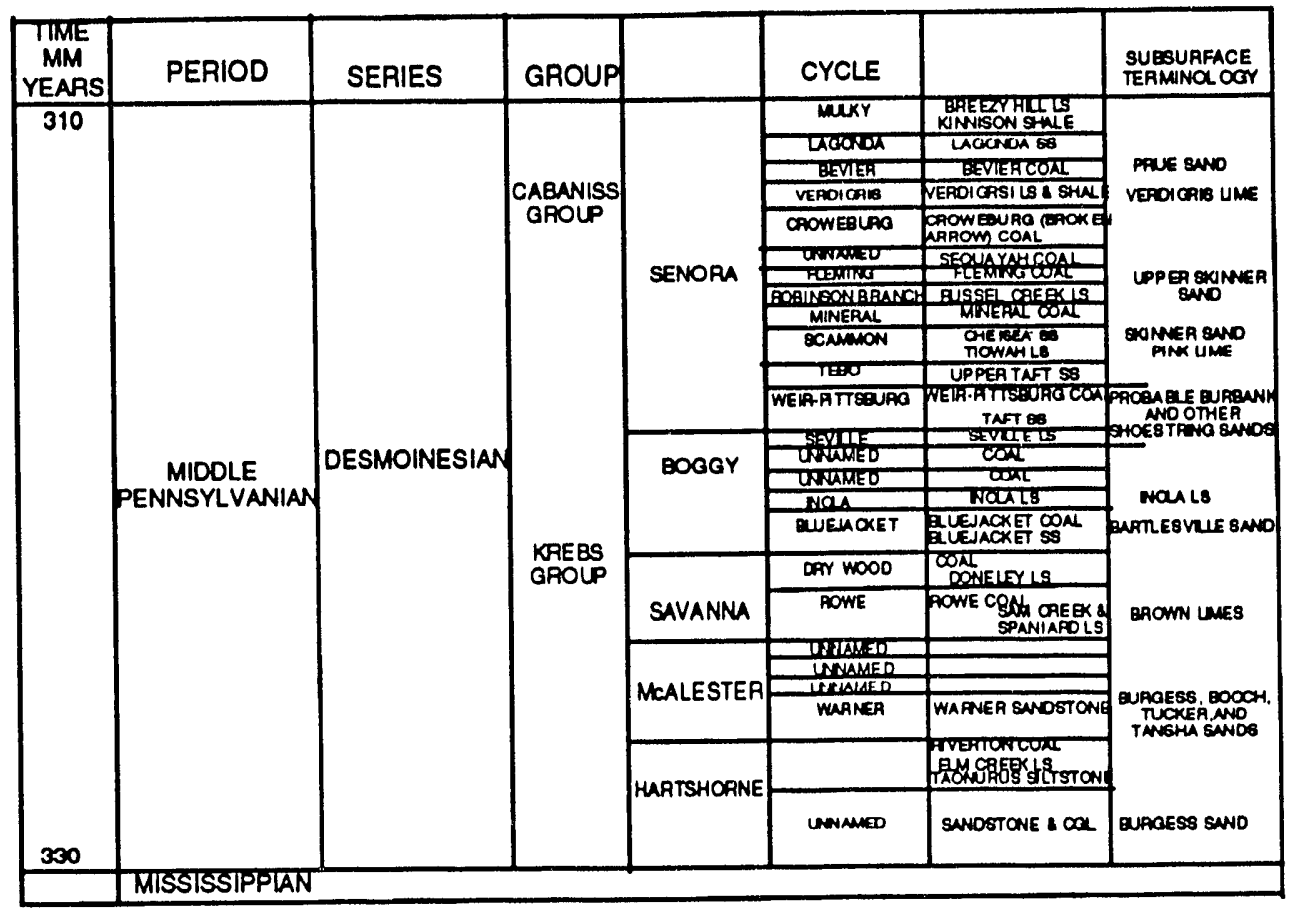

FIGURE 4.11. - Nomenclature of Middle Pennsylvanian Rocks in the Tri-State Area (from Harrison, 1979).

of the Cherokee Basin the following names are used for oil producing Cherokee Group sandstones: Prue sandstone, Skinner sandstone, Red Fork Sandstone, Bartlesville sandstone, Taneha (Tucker) sandstone and Burgess sandstone (Berry, 1963 and Shulman, 1965).

\section{South-Central Oklahoma}

\section{HEAVY OIL OCCURRENCE}

Harrison (1982) estimated the heavy oil reserves in South-Central Oklahoma to be 800 million barrels of heavy oil in place. This reserve is supposed to be held in five major deposits in Carter and Murray Counties, Oklahoma. These major heavy oil deposits are estimated to be at the Sulphur (discussed above), Dougherty, Newport, Ardmore, and Hewett locations. The South Sulphur deposit contains at least $50 \%$ of the heavy oil reserve in these accumulations (Harrison, 1982). Williams (1983) estimated, based on core hole data and measured sections, that the heavy oil in place at the Sulphur location is $\mathbf{3 7 6}$ million barrels. These heavy oil deposits are contained in the Ordovician, Simpson Group, Oil Creek sandstone on the surface and shallow subsurface. The 800 million barrels estimated by Harrison (1982) were revised in a later report by Harrison and Burchfield (1984). The South Sulphur measured heavy oil reserve is 33.8 million barrels and a probable 12.6 million barrels (Harrison and Burchfield, 1984). The South Woodford area has 8.0 million barrels of measured heavy oil reserve and a probable reserve of 2.4 million barrels (Harrison and Burchfield, 1984). These new reserve figures are approximately $5 \%$ of the original 
800 million barrel figure widely published prior to 1984. There are a few shallow wells in the Sulphur area that have produced heavy oil. Extensive mining of the asphaltic Oil Creek sandstone occurred prior to the 1950s. The mined asphalt rock was used for road surfacing material, but did not hold up well because the Oil Creek sandstone is poorly cemented. When the cementing material broken down or dissolved the roads surfaced with the asphaltic Oil Creek sandstone failed. Reserves are not given for the other deposits described by Harrison (1982). Many of the producing oil fields in South-Central Oklahoma produce heavy oil, but no estimated reserve figures are available for these fields.

\section{Cherokee Basin - Northeastern Oklahoma}

Harrison and Roberts (1979) performed a study in Ottawa and Craig Counties, Oklahoma where they assigned no heavy oil reserves to rocks of the Pennsylvanian, Cherokee Group sandstones in the Cherokee Basin. This is not hard to believe for the area that was studied. The remainder of the Cherokee Basin in Northeastern Oklahoma should contain heavy oil for the same reason heavy oil is found in the Kansas and Missouri portion of the same Cherokee Basin. These heavy oil resources are elusive and may be hiding behind casing somewhere in old oil fields where records have been lost or forgotten. The area of the Cherokee Basin in Northeastern Oklahoma is approximately the same as the Kansas portion of the basin. Therefore, a similar heavy oil volume may be contained in sandstones of the Cherokee Group in Northeastern Oklahoma, but quantification and documentation is difficult and not worthwhile since the economic producible oil volume is small.

\section{CASE STUDIES OF HEAVY OIL PROJECTS}

\section{Mobil Oil Company}

In August 1953, Mobil Oil Company implemented a combustion project in a shallow (180 ft) Pontotoc sandstone at Featherston Ranch, Stephens County, Oklahoma. The project was implemented on three- and five-spot well patterns in 1953 and 1954. The 5-spot pattern was a highly instrumented, controlled, and interpreted research project. Sweep of the fire front was controlled by geology of the reservoir, going in the direction of best continuous porosity and permeability. Approximately $26 \%$ of the pattern was swept by the combustion front. This pioneer project demonstrated that heavy oil is recoverable by fireflooding a reservoir.

\section{Shell Oil Company Steamflood project in Sho-Vel-Tum Field (1964-1966)}

Shell Oil Company implemented a steamflond project on its Hefner leases in the Tatums sector of Sho-Vel-Tum field in southern Oklahoma in 1964 (Table 4.1). The Hefner lease covered 60 acres with 4 injection wells and 20 producing wells in the Des Moines Zone VIII sand (Fourth 
TABLE 4.1. - Shell Oil Company, steamflood project, SHO-VEL-TUM field, Carter County, Oklahoma (1964-1966)

Porosity, \%

Permeability (air), $\mathrm{mD}$

Depth to top of reservoir (Des Moines Zone VIII), $\mathrm{ft}$

Gravity, ${ }^{\circ} \mathrm{API}$

Reservoir temperature, ${ }^{\circ} \mathrm{F}$

Viscosity at reservoir temperature, $\mathrm{cP}$

Steam quality, $\%$

Quantity of steam, tons/day

Angle of dip of reservoir, ${ }^{\circ}$

Oil saturation of reservoir at project implementation, \%

Lease size, acres

Primary cumulative oil production at project implementation, bbl

Number of injection wells

Number of producing wells

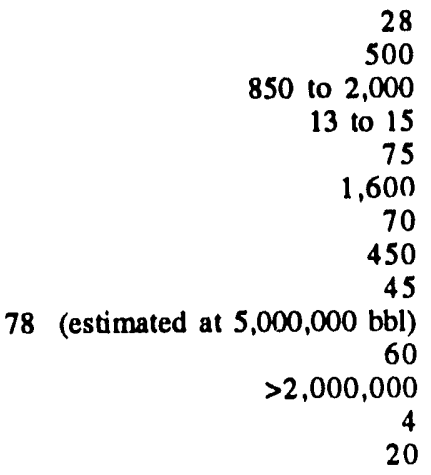

500

850 to 2,000

13 to 15

1,600

450

78 (estimated at $5,000,000 \mathrm{bbl}$ )

$>2,000,000$

20

Deese sand reservoir), Pennsylvanian system. The reservoir is truncated by an erosional unconformity updip to the northeast and is bounded on the southwest, downdip, by a relatively stable oil/water contact. Oil was discovered on this lease in the 1940s and had produced over 2 million barrels of oil by November 1964. The Shell Oil Company steamflood project was conducted during the same period of time that Mobil Oil Company was conducting combustion oil recovery tests on nearby leases. These projects did not interfere with each other. The Shell Oil Company steamflood project was successful at recovering incremental oil and increasing daily oil production.

\section{Mobil Oil Company Cox Penn Sand Fireflood (1962-1968)}

Mobil Oil Company implemented a fireflood project in the Cox Penn Sand Unit in the Ed Cox field portion of Sho-Vel-Tum field, Carter County, Oklahoma in 1962 (Table 4.2). Magnolia Petroleum Company discovered Ed Cox field in January 1926. The fireflood project was implemented in the Fourth Deese sand, Pennsylvanian system. The Fourth Deese sand of Mobile Oil Company and the Des Moines Zone VIII are the same producing formation. This heavy oil producing Deese sand is fine to medium grained, angular to subrounded, and poorly to loosely consolidated. The sand is truncated updip by an erosional unconformity and has an oil/water contact downdip. This project successfully recovered oil from a heavy oil reservoir. Mobil had difficulty dehydrating the crude oil to pipeline quality. More injection well capacity was needed to better utilize the capacity of the air compressors. 
TABLE 4.2. -Mobil Oil Company, Cox Penn sand fireflood, SHO-VEL-TUM field Carter County, Oklahoma (1962-1968)

Porosity, $\%$

Permeability, mD

Depth to top of reservoir, $\mathrm{ft}$.

Oil gravity, ${ }^{\circ} \mathrm{API}$

Oil viscosity, ${ }^{\circ} \mathrm{API}$

Water saturation, $\%$

Project size, acres

Dip angle of producing formation, ${ }^{\circ}$

Average daily production rate when project implemented, BOPD/well

Air injection wells

Producing wells

\section{Mobil Producing U.S. Inc. Cox Penn Cyclic Steam Pilot Project (1986-Present)}

Mobil Producing U.S. Inc. implemented a cyclic steam pilot project in the Cox Penn sand (Fourth Deese sand) in Sho-Vel-Tum field, Carter County, Oklahoma. This producing unit was unitized in 1961 prior to a fireflood pilot project in the same reservoir. Wells in this unit averaged 2 BOPD from this reservoir when unitized in 1961 (Table 4.3). Peak heavy oil production for a typical well during the present cyclic steam project is approximately 150 BOPD. Integrated engineering and geological studies were performed on the pilot project area prior to project implementation. These studies will be expanded prior to project extension from the present location. The Fourth Deese sand was deposited in a fluvial-deltaic environment (Figs. 4.12 through 4.15). The sand is vertically and laterally continuous with no shale breaks, by $\log$ interpretation. This sand is described as unconsolidated with few if any reactive minerals present

TABLE 4.3. - Mobil Producing U.S. Inc., Cox Penn cyclic steam, SHO-VEL-TUM FIELD, Carter County, Oklahoma (1986-Present)

Porosity, \%

Permeability, mD

Reservoir thickness, ft

Depth to top of reservoir, $\mathrm{ft}$

Oil gravity, ${ }^{\circ} \mathrm{API}$

Original-oil-in-place, bblacre-ft

Present oil saturation from $\log$ analysis, \%

Steam injection pressure (equipment design), psi

Steam injection temperature (equipment design), ${ }^{\circ} \mathrm{F}$

Dip of producing formation, ${ }^{\circ}$

Typical oil peak production per well, BOPD
25 to 33

800 to $9.600 \mathrm{mD}$

30 to 100

950 to 2,100

14 to 16

1,615

80

1.950

600

40

150 


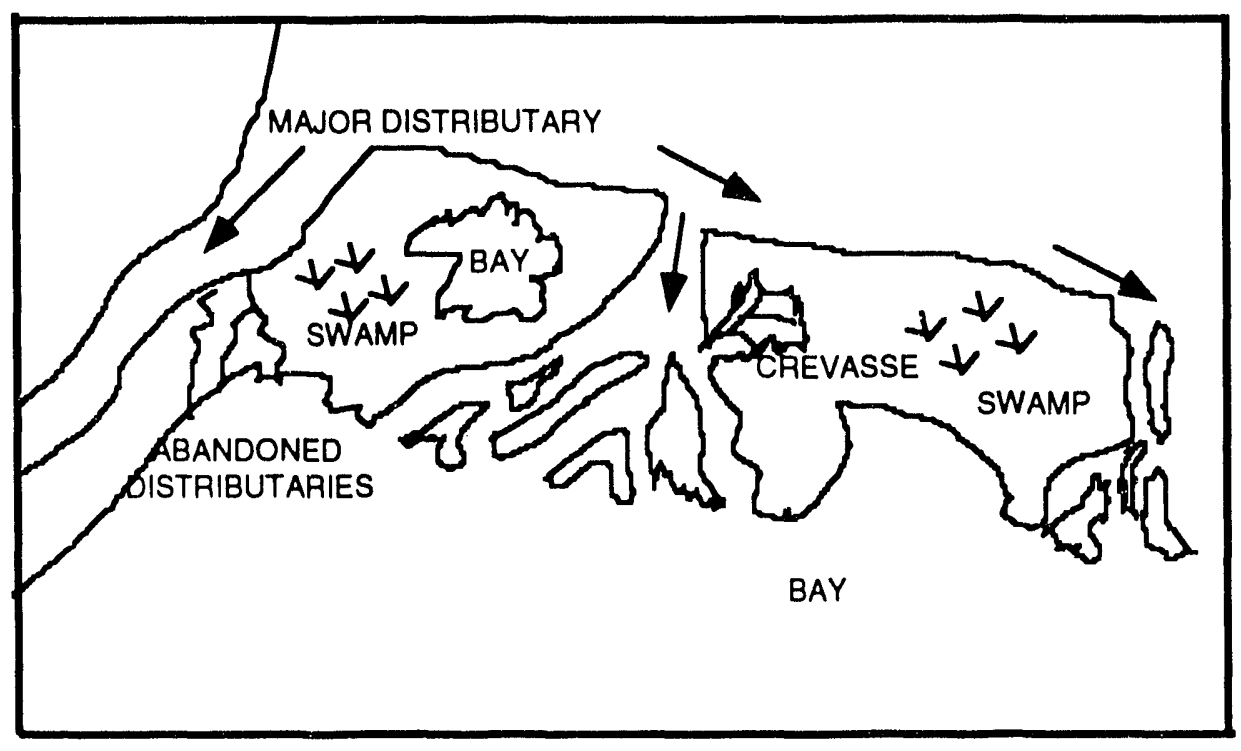

FIGURE 4.12. - Depositional Environment of the Cox Penn Reservoir.

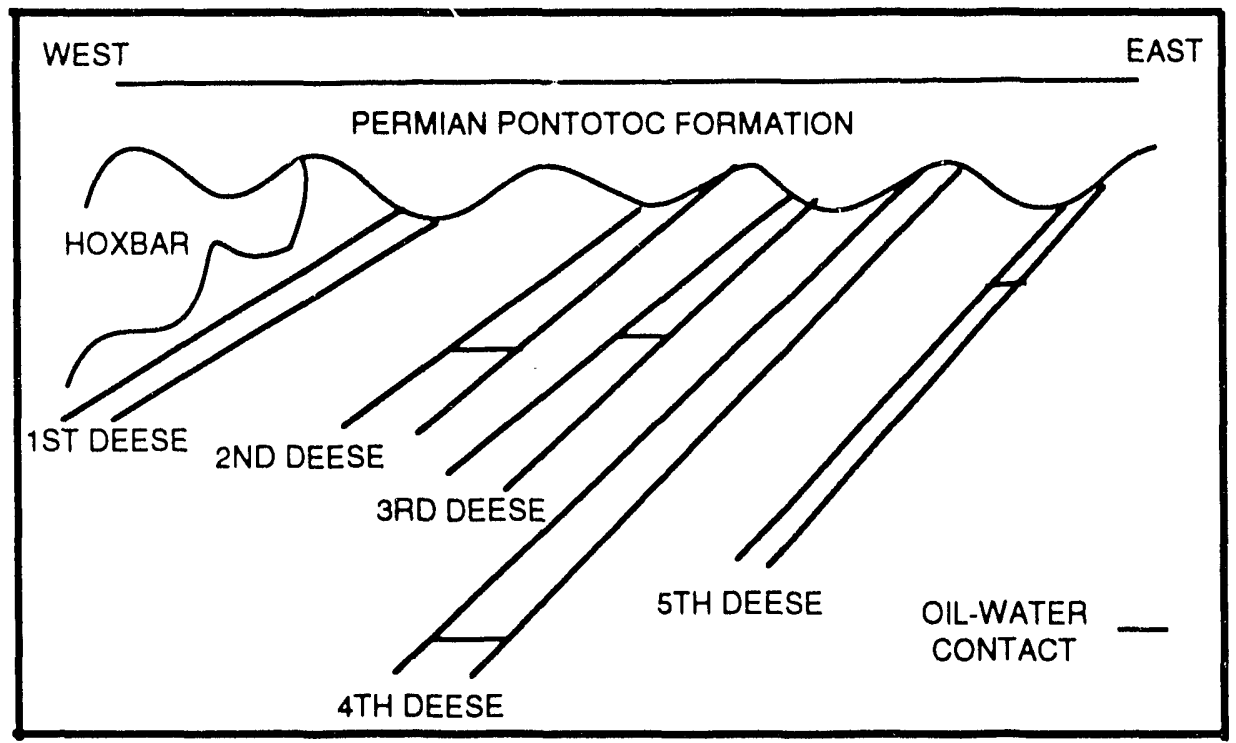

FIGURE 4.13. - Schematic Cross Section of the Cox Penn Reservoir. 


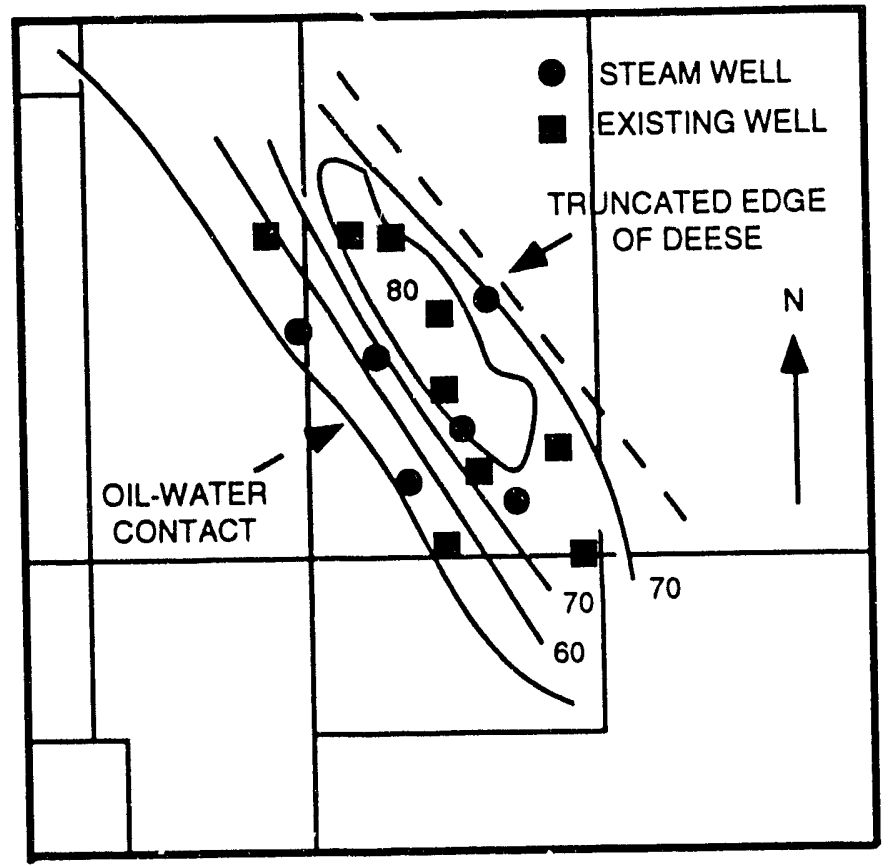

FIGURE 4.14. - Isochore of the Net Sand in the 4th Deese.

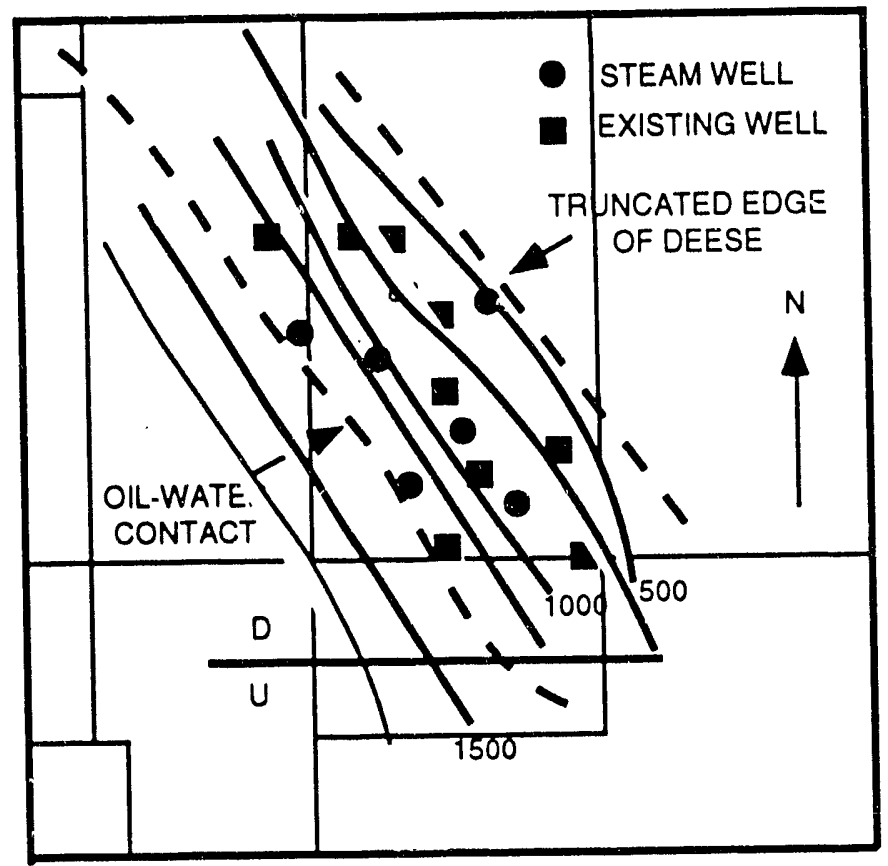

FIGURE 4.15. - Schematic Cross Section of the Cox Penn Reservoir. 


\section{BIBLIOGRA PHY}

A Survey of Oil Production in Oklahoma by Waterflooding-Part II. Counties Other Than Nowata, Rogers, and Craig, November 1951. U.S. Bureau of Mines Report No. 5832, 1951.

Aden, L. J. Clay Mineralogy and Depositional Environments of Upper Cherokee (Desmoinesian) Mudrocks, Eastern Kansas, Western Missouri, and Northeastern Oklahoma [Masters], University of Iowa, 1982.

Ball, S. M. Stratigraphy of the Douglas Group (Pennsylvanian, Virgilian) in the Northern Midcontinent Region [PhD]. Kansas Geological Survey, University of Kansas, 1964. Open File Report 64-1, 1964.

Ball, D., L. C. Marchant, A. Goldburg, ed. Tar Sands. Oklahoma City, OK: The Interstate Oil Compact Commission, 1982:232. The IOCC Monograph Series.

Ben-Saleh, F. F. Stratigraphic Analysis of Pennsylvanian Rocks in Southeastern Anadarko Basin, Oklahoma [Masters], University of Tulsa, 1970.

Berry, C. G. Stratigraphy of the Cherokee Group Eastern Osage County, Oklahoma [Masters], University of Tulsa, 1963.

Bertoni, S. S. Bluejacket Formation-A Subsurface Study in Northeastern Oklahoma [Masters], University of Tulsa, 1968.

Brenner, R. L. Stratigraphy, Petrology and Paleogeography of the Upper Portion of the Cherokee Group (Middle Pennsylvanian), Eastern Kansas and Northeastern Oklahoma. Lawrence, Kansas: Kansas Geological Survey, 1989 Geology Series 3.

Carlson, M. C. A Petrologic Analysis of Surface and Subsurface Atoka Formation (Lower Pennsylvanian) Sandstone, Western Margin of the Arkoma Basin, Oklahoma [Masters], University of Tulsa, 1988.

Chiou, R. C. S. and T. S. Murer. Cyclic Steam Pilot in Gravity Drainage Reservoir. SPE paper 19659. Pres. at Ann. Tech. Conf. and Exhib., San Antonio, TX, 1989.

Chism, J. Abandoned Oil Fields in Oklahoma. U. S. Department of Energy Report No. DOE/BETC/IC-83/4, 1983.

Cruz, J. A. Geometry an Origin of the Burbank Sandstone and Mississippian "Chat" in T25N, R6E and T26N, R6E. Osage County, Oklahoma [Masters], University of Tulsa, 1963.

Curiale, J. A. Petroleum Occurrences and Source-Rock Potential of the Ouachita Mountains Southeastern Oklahoma, Norman, OK: Oklahoma Geological Survey, 1983:65. Bulletin; v. 135).

Davis, L. V. Oil Possibilities Near Idabel, McCurtain County, Oklahoma. Oklahoma Geological Survey, 1953.

Denesen, S. L. Stratigraphy, Petrography, and Depositional Environments of the Banzet Formation (Middle Pennsylvanian) in Southeastern Kansas and Northeastern Oklahoma [Masters], University of Iowa, 1985. 
Ece, O. I. Depositional Environment, Stratigraphy, Petrology, Paleogeography, and Organic Thermal Maturation of the Desmoinesian Cyclothermic Excello Black Shale in Oklahoma, Kansas, and Missouri [PhD], University of Tulsa, 1985.

Fronjosa, E. A Study of Oklahoma Water Flood Statistics [Masters], University of Oklahoma, 1965.

Hagen, K. B. Mapping of Surface Joints on Air Photos Can Help Understand Waterflood Performance Problems at North Burbank Unit Osage and Kay Counties, Oklahoma [Masters], University of Tulsa, 1972.

Harrison, W. E., C. J. Mankin, S. J. Weber and J. A. Curiale. Oil-sand and Heavy-oil Potential of Oklahoma. The Future of Heavy Crude and Tar Sands. United Nations Institute for Training and Research, McGraw-Hill, Chpt. 9 in R. F. Meyer and C. T. Steele, eds., p. 8389

Harrison, W. E., J. F. Roberts and L. J. Heath. Evaluation of Heavy-Oil Potential of Northeastern Craig and Northwestern Ottawa Counties, Oklahoma. U.S. Department of Energy, Fossil Energy Division, Bartlesville Energy Technology Center, BETC/1812, June 1979 .

Harrison, W. E. and D. L. Routh. Reservoir and Fluid Characteristics of Selected Oil Fields in Oklahoma. (3rd ed.) Norman, Oklahoma: University of Oklahoma, 1981 Oklahoma Geological Survey's Special Publications, 81-1, 1981.

Harrison, W. E. Tar Sand Resource Appraisal in South-central Oklahoma. National Tar Sands (Heavy Oil) Symposium. Lexington, Kentucky: , 1982, pp. 110-128.

Harrison, W. E. and M. R. Burchfield. Tar-Sand Potential of Selected Areas in Carter and Murray Counties, South-Central Oklahoma. U.S. Department of Energy Report No. DOE/LC/10730-T-1, 1984.

Hatch, J. R., J. D. King and T. A. Daws. Geochemistry of Cherokee Group oils of southeastern Kansas and northeastern Oklahoma[sic].Lawrence, Kansas: U.S. Geological Survey (in cooperation with Kansas Geological Survey), 1989 Subsurface Geology Series; v. 11).

Hawisa, I. Sr. Depositional Environment of the Bartlesville, The Red Fork, and the Lower Skinner Sandstones in Portions of Lincoln, Logan and Payne Counties, Oklahoma [Masters], University of Tulsa, 1965.

Hough, R. M. Depositional Framework of the Lower Red Fork Eastern Flank of the Anadarko Basin, Oklahoma [Masters], University of Tulsa, 1978.

Hudson, A. S. Depositional Environment of the Red Fork and Equivalent Sandstones East of the Nemaha Ridge Kansas and Oklahoma [Masters], University of Tulsa, 1969.

IFC Resources Incorporated, Bureau of Economic Geology. Producing Unrecovered Mobile Oil: Evaluation of Potential Economically Recoverable Reserves in Texas, Oklahoma, and New Mexico. U.S. Department of Energy Report No. DOE/BL/14000-2, Secretary for Fossil Energy, 1990.

Interstate Oil Compact Commission. Major Tar Sands and Heavy Oil Deposits of the United States. Oklahoma City: Interstate Oil Compact Commission, Oklahoma City, Oklahoma, 1984, p. 272. 
Johnson K. S, T. W. Amsden and R. E. Denison. Geology of the Southern Midcontinent. Oklahoma Geological Society, 1989.

Johnston, K. H. and J. L. Castagno. Developments in Waterflooding and Pressure Maintenance in Osage County, Oklahoma Oilfields, 1961. U.S. Department of the Interior, U.S. Bureau of Mines Report No. 8038, 1961.

Jordan, L. Subsurface Stratigraphic Names of Oklahoma. Oklahoma Geological Survey, Guidebook VI, 1957.

Jordan, L. Petroleum-Impregnated Rocks and Asphaltite Deposits of Oklahoma. 3 ed. Oklahoma Geological Survey, Norman, Oklahoma: University of Oklahoma, 1964. Map GM-8 Scale 1:750,000.

Kansas Geological Survey. National Tar Sands (Heavy Oil) Symposium. National Tar Sands (Heavy Oil) Symposium. Lexington, Kentucky, 1982.

Kidd, C. M. Catalog of Theses and Dissertations Granted by the University of Oklahoma in Geology, Geophysics, and Selected Titles from Geological and Petroleum Engineering, 1904-1986. Oklahoma Geological Survey, Special Publication 88-1, 1988.

Knight, K. L. Stratigraphy, Depositional and Diagenetic History of Three Middle Pennsylvanian Cyclotherms (Breezy Hill and Fort Scott Limestones), Midcontinent North America [PhD], University of Iowa, May 1985. Kansas Geological Survey, Open File Report 85-18.

Krumme, G. W. Stratigraphic Significance of Limestones of the Marmaton Group (Pennsylvanian, Desmoinesian) in Eastern Oklahoma. Oklahoma Geological Survey, Bulletin 131, 1981.

McLaughlin, J. E. Annotated Bibliography of the Ardmore and Marietta Basins-Oklahoma. Dallas, TX: 1982 Geological Information Library of Dallas Bibliographies; University of Texas at Dallas, v. GILD 005). Publication No. 5, 1982.

McLaughlin, J. E. Annotated Bibliography of the Anadarko Basin Area Kansas-Oklahoma-Texas, 1984; v. GILD 007), p. 334.

McLaughiin, J. E. Supplement to Annotated Bibliography of the Ardmore and Marietta BasinsOklahoma, 1984; v. GILD 005).

McLaughlin, J. E. Supplement to Annotated Bibliography of the Anadarko Basin Area KansasOklahoma-Texas, 1985; University of Texas at Dallas, v. GILD 007).

McLemore, E. W. Annotated Bibliography of the Arkoma Basin Area Arkansas-Oklahoma. Dallas, TX: Geological Information Library of Dallas, 1981GILD Publication No. 3; v. GILD 003).

McLemore, E. W. Supplement to Annotated Bibliography of the Arkoma Basin Area ArkansasOklahoma. GILD, University of Texas, Dallas. Publication No. 3, 1983.

Moss, J. T., P. S. White and J. A. McNiel Jr. In Situ Combustion Process-Results of a FiveWell Field Experiment in Southern Oklahoma. Trans. AIME 1959; 216, pp. 55-64. 
O'Reilly, K. L. Diagenesis and Depositional Environments of the Red Fork Sandstone (Des Moinesian) in the Wakita Trend, Grant County, Oklahoma [Masters], University of Tulsa, 1986.

Phares, R. S. Depositional Framework of the Bartlesville Sandstone in Northeastern Oklahoma [Masters], University of Oklahoma, 1969.

Porter, E. S. The Coal and Asphalt of Oklahoma [Masters], University of Oklahoma, 1911.

Powell, J. H. and K. H. Johnston. A Survey of Oil Production in Oklahoma by Waterflooding: Part II. Counties Other Than Nowata, Rogers, and Craig. Bureau of Mines, 1951. Report of Investigations 4831, February 1952.

Powell, J. H. and K. H. Johnston. A Survey of Oil Production in Oklahoma by Waterflooding: Part 1. Nowata, Rogers, and Craig Counties. Bureau of Mines, 1952.

Powell, J. H. and J. L. Eakin. Waterflooding in Nowata County, Oklahoma Oil Fields. Bureau of Mines, 1952.

Powell, J. Some Recent Developments in Waterflooding in Washington County, OK, 1956-57. United States Bureau of Mines, 1957.

Price, R. C. Stratigraphy, Petrography, and Depositional Environments of that Pawnee Limestone Middle Pennsylvanian (Desmoinesian), Midcontinent North America [PhD], University of Iowa, 1981.

Ray, R. M. Producing Unrecovered Mobile Oil: Evaluation of Potential Economically Recoverable reserves in Texas, Oklahoma, and New Mexico. ICF Resources Incorporated and The Bureau of Economic Geology, Texas, 1990.

Riggs, C. H. and W. C. Smith. Water Flooding of Oil Sands in Washington County, Oklahoma. Bureau of Mines, 1951. Report of Investigations 4795, May 1951.

Riggs, C. H. Water Flooding in the Burbank Oil Field, Osage County, Oklahoma. United States Department of the Interior Bureau of Mines, 1954.

Scruton, P. C. The Petrography and Environment of Deposition of the Warner, Little Cabin, and Hartshorne Sandstones of Northeastern Oklahoma [Masters], University of Tulsa, 1949.

Shreveport Geological Society. 1961 Spring Field Trip Guide Book: Cretaceous of Southwest Arkansas and Southeast Oklahoma. 1961 Spring Field Trip. Cretaceous of Southwest Arkansas and Southeast Oklahoma, 1961.

Shreveport Geological Society. 1970 Spring Field Trip Guide Book: Southeast Oklahoma and Northeast Texas. Shreveport Geological Society 1970 Spring Field Trip, 1970.

Shulman, C. Stratigraphic Analysis of the Cherokee Group in Adjacent Portions of Lincoln, Logan, and Oklahoma Counties, Oklahoma [Masters], University of Tulsa, 1965.

Simpson, H. M. Palynology and the Vertical Sedimentary Profile of Missourian Strata, Tulsa County, Oklahoma [Masters], University of Tulsa, 1969.

Steam Flood Marks New Chapter in Oklahoma Oil. Petroleum Engineer 1964; (September 1964), pp. 106-107. 
Stewart, G. F. Paleotectonic Investigation of the Pennsylvanian System in the United States. Lawrence, Kansas: Kansas Geological Survey, 1971. Open File Report 71-11, 1971.

Suneson, N. H., J. A. Campbell and M. J. Tilford, ed. Geology and Resources of the Frontal Belt of the Western Ouachita Mountains, Oklahoma. Norman, OK: Oklahoma Geological Survey, 1990, p. 196. Special Publication.

Taliaferro, D. B. and S. M. Logan. History of Waterflooding Oil Sands in Oklahoma. U.S. Bureau of Mines Report No. 3728, November 1943.

Vanbuskirk, J. R. Investigation of Reservoir Conditions of Lower Deese Sandstones (Pennsylvanian) for a Flood Project in the North Alma Pool, Stevens County, Oklahoma [Masters], University of Oklahoma, 1960.

Weber, J. L. Oil-Oil and Oil-Rock Correlations: A Chemist's Perspective. Oklahoma Geological Survey, 1986.

Weber, J. L. Comparative Study of Crude-oil Compositions in Frontal and Central Ouachita Mountains, Oklahoma. Oklahoma Geological Survey, 1990:17. Oklahoma Geological Survey Special Publication 90-1.

Wells, J. S. Inventory of Heavy Oil in Western Missouri-Final Report. Department of Natural Resources, Division of Geology and Land Survey, Rolla, Missouri. Department of Energy BETC-1808-1, 1979.

Williarns, D. B. Structural and Geochemical Study of the Sulphur Asphalt Deposits, Murray County, Oklahoma [Masters], University of Oklahoma, 1983. 


\section{CHAPTER 5}

\section{ECONOMICS OF THERMAL HEAVY OIL PRODUCTION - OKLAHOMA, KANSAS, MISSOURI}

\section{RESULTS AND DISCUSSION}

The economics of the heavy oil recovery projects in the Midcontinent were analyzed based on the oil recovered and the reported duration of the project (oil produced per day was calculated). Costs were calculated using the current costs of thermal operation as obtained from the assessed evaluation of thermal (steam) operations in Kern County, California. The cost of drilling and completing thermal wells is shown in Table 5.1, and their yearly operating costs are shown in Table 5.2 (Maples, 1990). These average costs are based on proprietary data supplied by thermal operators and assembled by the Kern County, California Assessor for 1990. Initial installation costs for a conventional oil-fired steam generator under three different emission control scenarios were obtained from the Rand report (Nehring et al., 1983, Tables 5.3 and 5.4). An escalation factor was applied to the installation costs based upon EIA cost indices (EIA, 1990).

Although numerous independent operators produce heavy oil as primary production by use of a timer regulating their pumping units, their production per well is usually less than 0.3 BOPD. Since these operators continue to operate, the wells were deemed marginally economic at least in terms of generating "cash flow" and were not considered in this analysis because the volume of oil produced is too small and the recovery efficiency is less than 5\%. Conoco's heavy oil project in the Northeast Butterly Pool, located in Garvin, County Oklahoma is the exception and the most prolific heavy oil reservoir in the Midcontinent on primary production. This field produces 800 BOPD from 22 wells (Phillips and Whitt, 1983). Sand production in the field has been a problem since development in 1946-1949 (Butler et al., 1956). Methods to minimize sand production and land farming facilities for disposal of oily sand by bioremediation have been developed. No economics are published however, the field continues to be produced by a major oil company

TABLE 5.1. - Thermal EOR operating costs (Maples, 1990-91)

\begin{tabular}{ccc}
\hline Well depth, $\mathrm{ft}$ & $\begin{array}{c}\text { NEW PRODUCING WELL COSTS } \\
\text { Steam wells, } \$\end{array}$ & Injectors, $\$$ \\
\hline $0-250$ & 37,000 & \\
$251-750$ & 73,000 & 30,000 \\
$751-1,250$ & 89,000 & 60,000 \\
$1,251-1,750$ & 121,000 & 100,000 \\
$1,751-2,250$ & 160,000 & \\
$2,251-2,750$ & 200,000 & \\
$2,751-3,250$ & 240,000 & \\
\hline
\end{tabular}


TABLE 5.2. - Thermal EOR operating costs (Maples, 1990-91). Suggested yearly thermal steam operating cost ranges within each field/well

\begin{tabular}{lcc}
\hline Field & Cyclic steam, $\mathbf{S}$ & Steamflood, $\mathbf{S}$ \\
\hline Cymric & 20,000 & 27,500 \\
Kem River & 20,000 & 27,000 \\
Midway-Sunset & 18,000 & 26,000 \\
\hline
\end{tabular}

Steam generator maintenance costs/BTU barrel equivalent of oil burned, $\$$

Gas fired $=0.10^{-} \quad$ Oil fired $=0.20$

TABLE 5.3. - Characteristics of Conventional Oil-Fired Surface Steam Generator (from Nehring et al.,1983)

Heat input, $62.5 \mathrm{MMBtu} / \mathrm{hr}$

Heat output, 50.0 MMBtu/hr

Design capacity, 3,428 bbl-steam/day ${ }^{\mathrm{a}}$

Average daily output, 2,743 bbl-steam ( $80 \%$ capacity)

Annual output, $1,002,000$ bbl-steam

Steam quality, $80 \%$

Steam conditions, $350 \mathrm{psi}$, saturated temperature

Water requirement, 1,000,000 bbl/yr

Electricity requirement, $300,000 \mathrm{kwh} / \mathrm{yr}$

Fuel requirement, $10.0 \mathrm{bbl} / \mathrm{hr}$ of lease crude/hr or $70,800 \mathrm{bbl} / \mathrm{yr}^{\mathrm{b}}$

$\mathrm{SO}_{2}$ control efficiency, $95 \%$

$\mathrm{NO}_{\mathrm{x}}$ control efficiency

Case A - - 25\% (reduction from approximately .4 b/MMBTU_typical 62.5 MMBTU/hr steam generator burning

lease crude with nitrogen content of $.7 \%$ to $.8 \%$ by weight-to $.3 \mathrm{lb} / \mathrm{MMBTU}$ using low NO bumers)

Case B - 60\% (flue gas treatment-ammonia injection, selective noncatalytic reduction)

Case C - 85\% (flue gas treatment-ammonia injection, selective catalytic reduction)

Particulate control efficiency

Case A - 25\% to $35 \%$ (from the $\mathrm{SO}_{2}$ scrubbers)

Case B - 99+\% (mechanical air filtration)

Case C - 99+\% (mechanical air filtration)

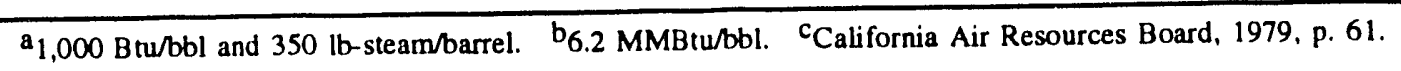


TABLE 5.4. - Conventional Oil-Fired Surface Steam Generator Costs (from Nehring et al., 1983)

\begin{tabular}{|c|c|c|c|}
\hline Item & $\begin{array}{c}\text { Cost }(\$) \\
\text { Case A }\end{array}$ & $\begin{array}{c}\text { Cost }(\$) \\
\text { Case B }\end{array}$ & $\begin{array}{l}\text { Cost }(\$) \\
\text { Case C }\end{array}$ \\
\hline \multicolumn{4}{|l|}{ Capital requirements } \\
\hline Steam generator & $\mathbf{a}_{320,000}$ & $a_{320,000}$ & $a_{320,000}$ \\
\hline $\begin{array}{l}\text { Steam piping, valves, insulation } \\
\text { Pollution control }\end{array}$ & $b_{197,000}$ & $c_{197,000}$ & $b_{197,000}$ \\
\hline $\mathrm{SO}_{2}$ & $\mathrm{a}_{174,000}$ & $a_{174,000}$ & $a_{174,000}$ \\
\hline $\mathrm{NO}_{\overline{\mathrm{T}}}$ & 0 & $a_{200,000}$ & $a_{1,090,000}$ \\
\hline Particulates & 0 & $a^{2}-38.000$ & a 38.000 \\
\hline Subtotal & 691,000 & 929,000 & $1,819,000$ \\
\hline Contingency & 0 & $\mathrm{~d}_{40,000}$ & $d_{218,000}$ \\
\hline Working capital & a 8.000 & a $\quad 8.000$ & a $\quad 8.000$ \\
\hline \multicolumn{4}{|l|}{$\begin{array}{l}\text { Annual O\&M costs } \\
\text { Steam generator }\end{array}$} \\
\hline Power & ${ }_{14,000}$ & $a_{14,000}$ & $a_{14,000}$ \\
\hline Maintenance & $a_{13,000}$ & $a_{13,000}$ & $a_{13,000}$ \\
\hline Operating labor (.1? ishift) & $a_{20,000}$ & $\mathrm{a}_{20,000}$ & $a_{20,000}$ \\
\hline Overhead & $a_{20,000}$ & $a_{20,000}$ & $a_{20,000}$ \\
\hline Water & $a_{23,000}$ & $a_{23,000}$ & $a_{23,000}$ \\
\hline $\begin{array}{l}\text { Subtotal } \\
\text { Pollution control }\end{array}$ & 90,000 & $\overline{90,000}$ & 90,000 \\
\hline $\mathrm{SO}_{2}$ & $c_{100,000}$ & $c_{100,000}$ & $c_{100,000}$ \\
\hline $\mathrm{NO}_{\mathbf{x}}$ & 0 & $\mathbf{e}_{31,000}$ & $\mathrm{e}_{222,000}$ \\
\hline Particulates & 0 & ${ }^{a} 294.000$ & $a_{294.000}$ \\
\hline Subtotal & $1 \overline{00,000}$ & 425,000 & 616,000 \\
\hline Total & 190,000 & 515,000 & 706,000 \\
\hline
\end{tabular}

a Norton, J. F. et al pp. 6-22; b Lewin, p. 27 and scaled as exponent of 0.9 assumed to scale back.

c Lewin, p. 27. d $20 \%$ of $\mathrm{NO}_{\mathrm{x}}$ control capital costs. e Capital component backed out.

whose rate of return is usually high or the property would have been sold to a smaller operator who costs of operation are usually less.

Table 5.1 shows new well costs for steam wells (injector and producer as the same well operating on cyclic steam) and for a infill steam injector. For thermal EOR nearly all wells have to be new wells to withstand the stress of being heated. Table 5.2 are representative operating costs including overhead where the cost of operation has been divided by the number of wells of each type in the field. The costs are representative of having well established local infrastructure to support thermal operations. Table 5.3 lists characteristics of a typical 50,000,000 BTU/hr steam generator operating under any of three emission control scenarios (Case A, B, C) whose cost of operation in 1981 are shown in Table 5.4. Since that time oil prices have decreased and used oilfired steam generators have become available due to being replaced by gas-fired steam generators and cogenerators. No attempt has been made to update these costs and are only provided as a 
guide and the cost of operation using the Table 5.2 was used for comparison. To determine the cost per barrel of oil produced, oil production per well for the three fields in Table 5.2 were divided by the 1989 oil production (Conservation Committee of Califomia Oil Producers, 1989) Estimates by California Department of Oil and Gas, thermal operating costs are approximately $\$ 8 / \mathrm{bbl}$ for oil using gas fired cogenerators; $\$ 9 / \mathrm{bbl}$ for gas fired steam generators and $\$ 10 / \mathrm{bbl}$ for oil fired steam generators (Guerard, 1990). Gill (1990) estimated thermal produced oil costs between $\$ 4.35$ and $\$ 8.00 / \mathrm{bbl}$. Costs to drill and equip a $1,000 \mathrm{ft}$ steam injector and producer are shown in Tables 5.5 and 5.6 (Sarathi and Olsen, 1992). In analyzing the economics of each of the heavy oil projects, the total oil produced over the life of the project was divided by the life of the project in days, Table 5.7. With the 1990 operating cost per well and the market price for heavy oil very few of the projects would be economical. The exception may be Mobil's steamflood pilot in Carter County, Oklahoma which is the only thermal heavy oil recovery project that is active. Recently, Kansas Incorporated commissioned a study of the factors affecting the economics of oil production in Kansas and made a comparison with those of surrounding states. A tabular listing of the royalties and tax liabilities within the Midcontinent states is shown in Table 5.8.

Many of the heavy oil producers in the Midcontinent reported that they were receiving $\$ 3.00$ to $\$ 5.00$ under the posted price for West Texas Intermediate for their heavy oil. This is significantly more per barrel of oil (when discounted for API gravity) than the market price for Kern River, California heavy oil, Table 5.9 and Fig. 5.1 (from Maples, 1990). Several factors may be contributing to this higher price in the Midcontinent. Kern River crude may be priced artificially low due to competition in the California heavy oil market and/or Midwest refiners are not imposing as stiff a penalty per degree API as California refiners because of the low volume of heavy oil being blended with a large volume of light sweet and light sour crude oil being processed (Gill, 1990). California heavy oil is asphaltic whereas Midcontinent heavy oil is paraffinic which refines to yield higher priced products. It is not anticipated that these high prices in the Midcontinent would continue if significant heavy oil were available because the refineries in the Midcontinent have a low capacity for processing heavy oil. If significant Midcontinent heavy oil were to be produced tomorrow, the price of heavy oil in the Midcontinent would be lower than Kern River because refineries would not be able to economically process the oil.

Only three thermal heavy oil recovery projects described in Chapters 2-4 were deemed economical. Carmel Energy/DOE's Vapor Therm project in the Add Carmel Energy Allen County, Kansas (Eastburn Field in Vernon County, Missouri (reference) and Mobil's steamflood pilot in Carter County, Oklahoma (Chiou and Murer, 1989). With the exception of published papers presented as part of Society of Petroleum Engineers meetings (Chiou and Murer, 1989) and the oil production reported in public records in the Oklahoma Corporation Commission, no additional 
TABLE 5.5 - Cost to drill and equip a 1,000 ft steam injection well (in 1990 dollars) (from Sarathi and Olsen, 1992)

Drilling:

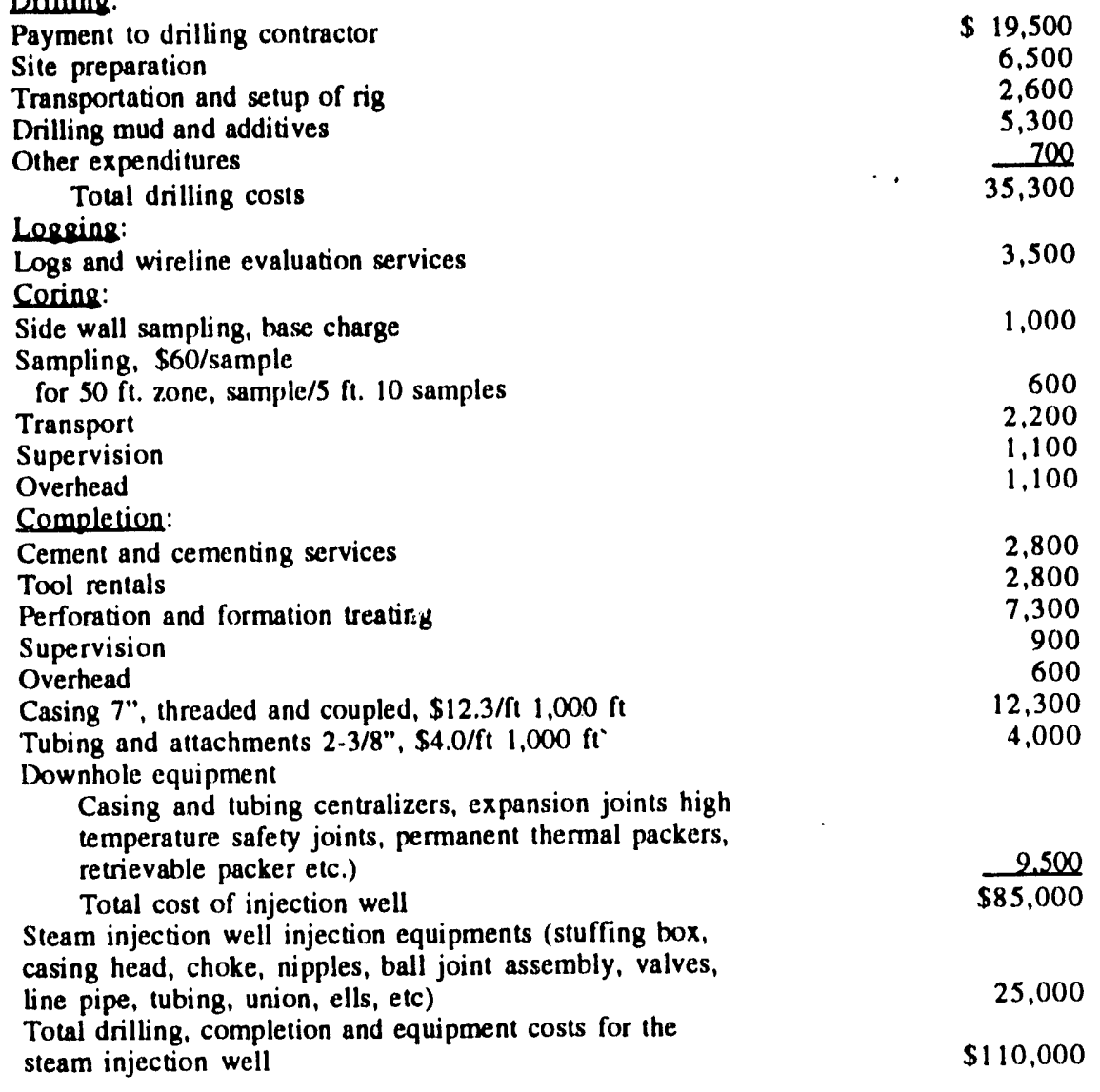

TABLE 5.6 - Cost to drill and equip a 1,000 ft steam production well (in 1990 dollars) (from Sarathi and Olsen, 1992)

Drilling:

Payment to drilling contractor

Site preparation

Transportation and setup of rig

Fuel

Drilling mud and additives

Other expenditures

Total drilling costs
$\$ 19,500$
6,500
2,600
700
5,300
700
$\$ 35,300$
or $\$ 35.3 / \mathrm{ft}$


TABLE 5.6 - Cost to drill and equip a 1,000 ft steam production well (in 1990 dollars) (from Sarathi and Olsen, 1992)-Continued

\begin{tabular}{|c|c|}
\hline $\begin{array}{l}\text { Logging: } \\
\text { Logs and wireline evaluation services }\end{array}$ & $\$ 3,500$ \\
\hline Coring: & 2,000 \\
\hline $\begin{array}{l}\text { Sampling, } \$ 60 / \text { sample } \\
\text { for } 50 \mathrm{ft} \text { zone, sample } 5 \mathrm{ft}, 10 \text { samples }\end{array}$ & 600 \\
\hline $\begin{array}{l}\text { Transport } \\
\text { Supervision } \\
\text { Overhead } \\
\text { Completion: }\end{array}$ & $\begin{array}{l}2,200 \\
1,100 \\
1,100\end{array}$ \\
\hline Cement and cementing services & $\$ 2,000$ \\
\hline Tool rentals & 2,800 \\
\hline Perforation and formation treating & 7,300 \\
\hline Supervision & $\begin{array}{l}900 \\
600\end{array}$ \\
\hline $\begin{array}{l}\text { Overhead } \\
\text { Casing 7" treaded and coupled, } \$ 12.3 / \mathrm{ft} 1,000 \mathrm{ft}\end{array}$ & 12,300 \\
\hline $\begin{array}{l}\text { Casing 7" treaded and coupled, } \$ 1.3 / 1 \mathrm{t}, 00 \mathrm{It} \\
\text { Production tubing 2-3/8", \$4.0/ft } 1,000 \mathrm{ft} \\
\text { Downhole Equipment: }\end{array}$ & 4,000 \\
\hline $\begin{array}{l}\text { Telescoping expansion joints, production packers } \\
\text { centralizer, gravel pack }\end{array}$ & $\$ 7.300$ \\
\hline $\begin{array}{l}\text { Total cost of production well } \\
\text { Subsurface rod pump assembly with gas anchor, } 3 / 4 \text { " API }\end{array}$ & $\$ 82,800$ \\
\hline $\begin{array}{l}\text { Subsurface rod pump assembly with gas ancnor, } 3 / 4 \text { ArI } \\
\text { class } C \text { sucker rod } \\
228,000 \text { in lb-torque API } 228-213-86 \text { pumping unit }\end{array}$ & $\begin{array}{l}\$ 11,000 \\
\$ 23,000\end{array}$ \\
\hline Total cost of production well & $\$ 116,800$ \\
\hline
\end{tabular}

TABLE 5.7. - Oil production in thermal heavy oil projects in the Midcontinent

\begin{tabular}{|c|c|c|c|c|c|c|c|}
\hline Description & Location & Process & $\begin{array}{l}\text { Project } \\
\text { life, } \\
\text { yr }\end{array}$ & $\begin{array}{l}\text { Total } \\
\text { oil } \\
\text { barrels }\end{array}$ & $\begin{array}{c}\text { CDOR, }{ }^{1} \\
\text { barrels }\end{array}$ & Wells & BOPD $/ w^{3}$ \\
\hline $\begin{array}{l}\text { U.S. DOE } \\
\text { Sun Oil } \\
\text { Sinclair }\end{array}$ & $\begin{array}{c}\text { Bartlett, KS } \\
\text { Iola, KS } \\
\text { Allen Co., KS }\end{array}$ & $\begin{array}{l}\text { Fireflood } \\
\text { Fireflood }\end{array}$ & 4 & $\begin{array}{l}61,766 \\
79,000\end{array}$ & $\begin{array}{l}<1 \\
52\end{array}$ & $\begin{array}{l}20 \\
20\end{array}$ & $\begin{array}{l}2.6 \\
2.7\end{array}$ \\
\hline $\begin{array}{l}\text { Carmel Energy } \\
\text { Carter } \\
\text { Shell } \\
\text { Dotson Oil } \\
\text { Jones-Blair }\end{array}$ & $\begin{array}{c}\text { Allen Co., KS } \\
\text { Deerfield, MO } \\
\text { Vernon Co., MO } \\
\text { Vernon Co., MO } \\
\text { Stotsbury Fld., MO }\end{array}$ & Steam & $\begin{array}{l}1.5 \\
4 \\
2 \\
4 \\
5\end{array}$ & $\begin{array}{c}4,222 \text { est } \\
6,752 \\
6,600 \\
17,953 \\
133,018\end{array}$ & $\begin{array}{c}4.6 \\
12.3 \\
73\end{array}$ & $\begin{array}{c}16 \\
32 \\
32 \\
N A^{2}\end{array}$ & $\begin{array}{l}7.8 \\
0.29 \\
.28 \\
0.384\end{array}$ \\
\hline
\end{tabular}

1 CDOR - Calendar day oil recovery.

2 NA - Not available.

${ }^{3}$ BOPD/W - Barrels of oil per day per well. 
TABLE 5.8 - Comparisons of economic factors affecting oil production from Midcontinent states

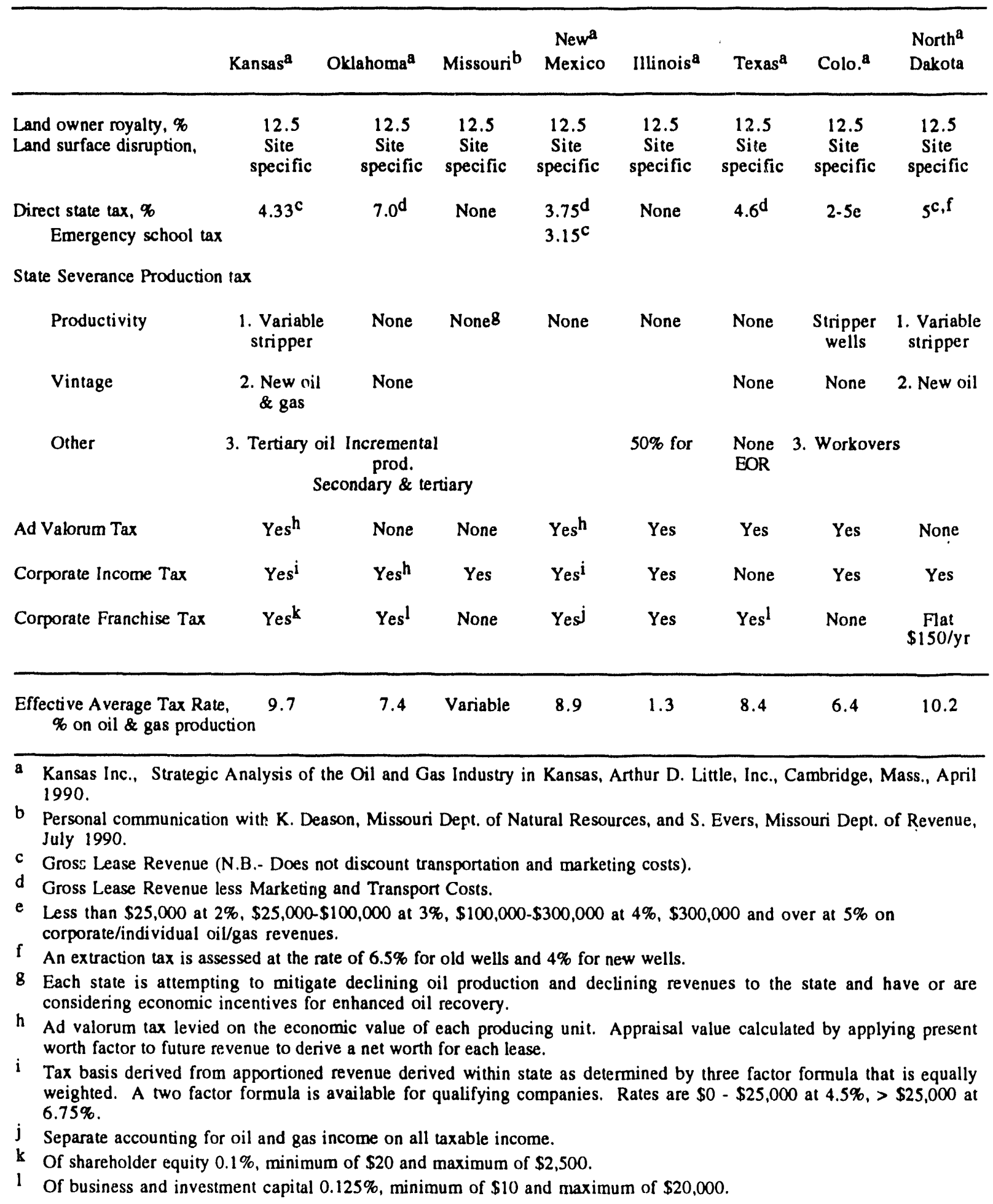


TABLE 5.9. - Crude oil prices of the last decade ${ }^{1}$ (from Maples, 1990)

\begin{tabular}{|c|c|c|c|c|c|c|c|}
\hline Year & $\begin{array}{l}\text { Arab } \\
\text { Heavy, } \\
\text { S/bbl }\end{array}$ & $\begin{array}{l}\text { Arab } \\
\text { Light, } \\
\text { S/bbl }\end{array}$ & $\begin{array}{c}\text { West } \\
\text { Texas } \\
\text { Inierinediate, } \\
\text { Sbbl }\end{array}$ & $\begin{array}{l}\text { Kern } \\
\text { River, } \\
\text { S/bbl }\end{array}$ & $\begin{array}{c}\text { K.R./ } \\
\text { Arab } \\
\text { Heavy, } \\
\text { Ratio }\end{array}$ & $\begin{array}{l}\text { K.R.I } \\
\text { Arab } \\
\text { Light, } \\
\text { Ratio }\end{array}$ & $\begin{array}{c}\text { K.R.f } \\
\text { WTI } \\
\text { Ratio }\end{array}$ \\
\hline $\begin{array}{l}1981 \\
1982 \\
1983 \\
1984 \\
1985\end{array}$ & $\begin{array}{l}31.75 \\
29.09 \\
26.62 \\
26.67 \\
26.80\end{array}$ & $\begin{array}{l}34.27 \\
31.74 \\
28.76 \\
28.07 \\
27.52\end{array}$ & $\begin{array}{r}-. \\
30.33 \\
29.37 \\
28.01\end{array}$ & $\begin{array}{l}25.18 \\
21.97 \\
20.14 \\
20.89 \\
20.18\end{array}$ & $\begin{array}{l}.793 \\
.755 \\
.757 \\
.783 \\
.753\end{array}$ & $\begin{array}{l}.735 \\
.692 \\
.700 \\
.744 \\
.733\end{array}$ & $\begin{array}{r}\cdots \\
.664 \\
.711 \\
.720\end{array}$ \\
\hline $\begin{array}{l}1986 \\
1987 \\
1988 \\
1989 \\
1990\end{array}$ & $\begin{array}{l}12.33 \\
16.23 \\
12.20 \\
14.93 \\
18.76\end{array}$ & $\begin{array}{l}13.32 \\
17.28 \\
13.45 \\
16.21 \\
20.80\end{array}$ & $\begin{array}{l}15.04 \\
19.1 ; \\
15.98 \\
19.69 \\
24.51\end{array}$ & $\begin{array}{r}9.42 \\
13.34 \\
9.79 \\
12.77 \\
16.15\end{array}$ & $\begin{array}{l}.764 \\
.822 \\
.802 \\
.855 \\
.861\end{array}$ & $\begin{array}{l}.707 \\
.772 \\
.728 \\
.788 \\
.776\end{array}$ & $\begin{array}{l}.626 \\
.696 \\
.613 \\
.649 \\
.659\end{array}$ \\
\hline $\begin{array}{l}\text { Average of } \\
1982-1990\end{array}$ & 19.32 & 20.68 & 22.76 & 12.27 & .795 & .738 & .667 \\
\hline
\end{tabular}

1 FOB Crude Oil Spot Prices-Annual Basis.

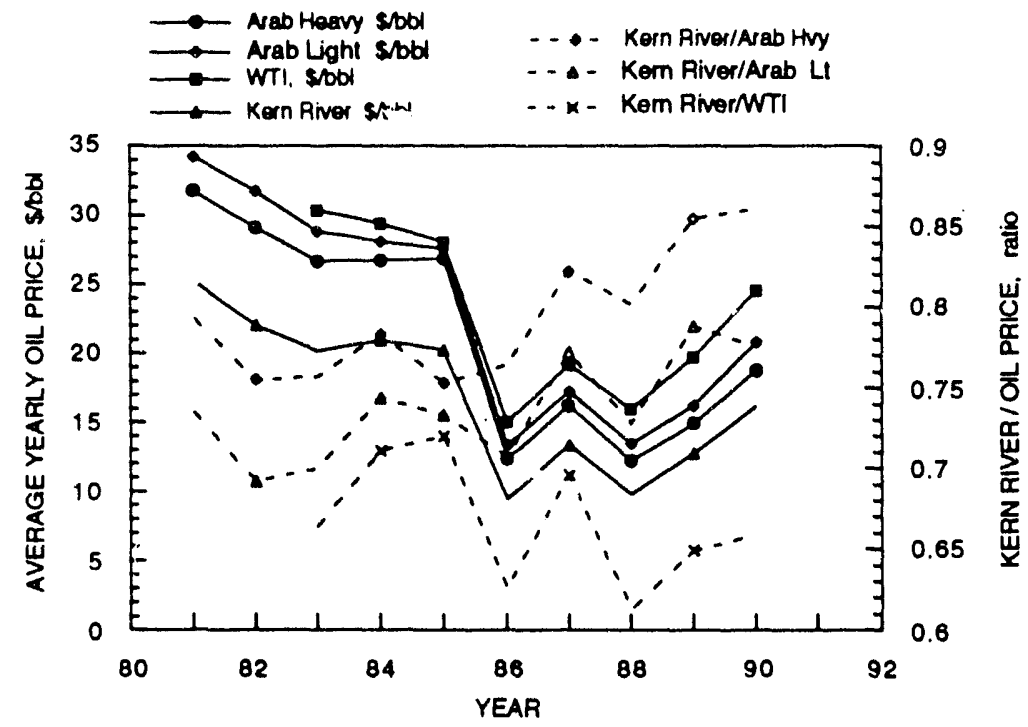

FIGURE 5.1. - Comparison of average yearly oil price of benchmark crude oils with Kern River $13^{\circ}$ API gravity oil (from Maples, 1990). 
economic data was available. With current restrictions on pressure, and EPA's ground water and air quality regulations, duplication of the Carmel Energy's project would be unfeasible. Not only in these pilots but in numerous other pilots, operators found previous wells, abandoned and unknown wells, were liabilities not an asset. The literature contains references to casing, which was cemented only at the surface, expanding and tipping the pump jack over as the producing well became hot. Poorly plugged, abandoned, and unknown wells leaked hot water, hot gases, and oil to the surface, sometimes explosively ejecting the casing, fence posts used as plugs, etc. until the pressure had decreased. Very few of the wells completed or drilled for injection of steam or air would meet current engineering standards. Wells with the most problems were those cemented at the surface with a few bags of cement and a rag packer on the bottom. Olcl wells drilled decades ago, some as early as the 1920-30s, cannot hold pressure and are liabilities. Not only are new competent wells needed for thermal production, but old wells have to be plugged.

Economic heavy oil projects will be those that take advantage of the a formation's unconsolidated sand and high permeability with gas fired steam generation to produce steam to reduce viscosity to enhance the gravity drainage of heavy oil for production.

\section{BIBLIOGRAPHY}

Butler, R., S. D. McCloud and J. Marshall. Northeast Butterly Pool - Case History, J. Pet. Tech., February 1956, p 23-26.

California Air Resources Board. Status of $\mathrm{NO}_{\mathrm{x}}$ Control for Steam Generators and Availability of $\mathrm{NO}_{x}$ Tradeoffs in Kern County, Staff Report No. 79-27-lb, October 28, 1979, p. 61.

Chiou, R. C. S. and T. S. Murer. Cyclic Steam Pilot In Gravity Drainage Reservoir, SPE paper 19659 presented at the 64th annual Technical Conference and Exposition, San Antonio, TX October 8-11, 1989.

Conservation Committee of California Oil Producers, Annual Review of California Oil \& Gas Production 1989. Conservation Committee of California Oil Producers, Los Angeles, California, 199(), pp. H-2 to H-3.

Gill, D. Kern County. Oil and Gas Investor, August 1990, pp. 14-27.

Kansas Inc. Strategic Analysis of the Oil and Gas Industry in Kansas, Arthur D. Little, Inc., Cambridge, Mass., April 1990.

Lewin and Associates. Economics of Enhanced Oil Recuvery, U. S. Dept. of Energy report ET/12-72-2, May 1981.

Maples, J. W. Kern County Assessor. Kern County, California. Oil and Gas Properties Appraisal Parameters, 1990-1991, March 1990.

Maples, J. W. Crude Oil Prices 1990. Kern County Assessor, Oil and Gas Properties Division, Kern County, California, February 1991. 
Nehring, R., R. W. Hess and M. Kamionski. The Heavy Oil Resources of the United States. Rand Corporation R-2946-DOE, 1983)

Norton, J. F. The Options for Increasing California Heavy Oil Production, Radian Corporation, Sacramento, California, November 1981.

Personal communication with K. Deason, Missouri Dept. of Natural Resources, and S. Evers, Missouri Dept. of Revenue, July 1990.

Personal communication with W. F. Guerard, Califomia Dept. of Conservation, Division of Oil and Gas, August 1990.

Phillips, F. L. and S. R. Whitt. Success of Openhole Completions in the Northeast Butterly Field, Southern Oklahoma, SPE paper 11555 presented at SPE Production Operation Symposium, Oklahoma City, Oklahoma, February 27-March 1, 1983.

Sarathi, P. S. and D. K. Olsen. Practical Aspects of Steam Injection Processes-A Handbook for Independent Operators, U. S. DOE Report NIPER-580, October 1992. 


\section{CHAPTER 6}

\section{APPLICATION FOR HORIZONTAL WELLS AND INFILL DRILIING}

\section{BACKGROUND}

Horizontal/directional well drilling and completion technology have made great advancements during the 1980s and continue to advance into the 1990s. Extensive onshore implementation of advanced horizontal drilling technology occurred with improved downhole logging and steering equipment and development of advanced downhole mud motors for drilling without rotating the drill pipe at the surface. With these improvements, this technology has been most successfully implemented in naturally fractured carbonate and shale oil reservoirs and in coal and fractured shale gas reservoirs. This technology has been used for both exploration and exploitation of hydrocarbons in these reservoirs. The attraction of horizontal technology for light oil has been increased daily oil production in horizontal wells over vertical wells.

Application of advanced horizontal/directional technology for heavy oil reservoirs for production and/or injection wells is yet to be proven. This technology may not be the best technology for all oil and gas reservoirs, whether light or heavy. Successful application of horizontal/directional technology is contingent upon geology and geologic history of the oil reservoir. Prior to selection of horizontal/directional technology for a reservoir, reservoir characterization should be performed to minimize chances for failure to improve production. Use of this technology for injection wells could be the best application.

\section{Horizontal Wells}

Use of horizontal wells for heavy oil recovery has been reported by Netzler (1990) in Bitterroot Field in Missouri. These were drilled by Town Oil Company for use as water injectors and producers. They were drilled parallel and perpendicular to the direction of best porosity and permeability. At the time of Netzler's report, no results had been reported. In a 1990 conversation with Lester Town of Town Oil Company, results of the horizontal wells as injectors and producers were not the success that had been expected (Town, 1990).

Prior to implementation of a horizontal drilling program, integrated economic, engineering, and geologic analyses of the reservoir and feasibility for use as injectors and/or producers should be completed. In the fluvial deltaic sandstone reservoirs of the Midcontinent it is necessary to determine which facies will be penetrated by the horizontal portion of the well. Placement of the horizontal portion in a lower trough bedded facies to be used an injector with vertical producers could possibly recover economic amounts of oil. It is suggested that cyclic steam be implemented in the horizontal well followed by steamflooding after a few cycles. Use of horizontal wells as injectors is suggested because production is normally higher in a horizontal well than in a vertical 
well. With a horizontal producer, required injection rates in vertical or horizontal wells may be beyond the capability of surface and downhole equipment for economic application.

Placement of a horizontal well in an upper facies may result in heavy oil recovery, but economic failure, as seen in Eastburn Field by Carmel Energy when vertical wells were used, may result. Horizontal wells will contact more unfavorable low recovery reservoir rock than contacted by vertical wells. The same restrictions that apply to vertical wells of discontinuous facies limiting oil production will apply to horizontal wells in a reservoir. Horizontal wells may not be a cure all for unfavorable geology.

Midcontinent reservoirs tend to have natural fracture patterns more or less in a northeastsouthwest direction (Hagen, 1972, and Johnsgard, 1988). When performing integrated economic, engineering, and geologic analyses of consolidated fluvial-dominated deltaic sandstone reservoirs, placement of horizontal wells to utilize natural fracture patterns should be considered.

Horizontal wells should be considered for use in carbonate reservoirs containing heavy oil resources. Carbonate rocks are commonly fractured. To date horizontal wells have proven to increase oil production, yielding higher cumulative production over a short period of time in light oil reservoirs, and they may do the same in naturally fractured heavy oil reservoirs. When performing integrated economic, engineering, and geologic analyses of carbonate heavy oil reservoirs, horizontal wells should definitely be one of the primary considerations.

\section{Infill Drilling}

Infill drilling in fluvial-dominated deltaic sandstone reservoirs should be considered when performing integrated economic, engineering, and geologic analyses. Economic placement of this type of well for lateral variation of an upper facies or thin lower trough bedded facies may be feasible, whereas implementation of horizontal technology may be too costly. These wells should be considered for application with cyclic steam in an upper facies and with cyclic steam converted to steamflooding in a lower trough bedded facies. Integrated analyses should determine feasibility for application of horizontal technology or infield drilling. Very few Midcontinent reservoirs have been drilled on a spacing that accommodates the compartmentalization (internal architecture) of the reservoir.

\section{BIBLIOGRAPHY}

Butler, R. M. The Potential for Horizontal Wells for Petroleum Production, J. Can. Pet. Tech., v. $28(3), 1989$, pp. $39-47$.

Hagen, K. B. Mapping of Surface Joints on Air Photos Can Help. Understanding Waterflood Performance Problems at North Burbank Unit, Osage and Kay Counties, Oklahoma, [MS Thesis], University of Tulsa, 1972. 
Johnsgard, S. K. The Fracture Pattern of North-central Kansas and Its Relation to Hydrogen Soil Gas Anomalies Over the Midcontinent Rift System [MS Thesis], University of Kansas, 1988.

Netzler, B. W. Heavy Oil Resource Potential of Southwest Missouri. Missouri Department of Natural Resources. Report No. OFR-90-80-06, 1990.

Personal communication with Lester Town, Town Oil Company, Iola, Kansas, June 1990. 


\section{CHAPTER 7}

\section{ENVIRONMENTAL, FACTORS AFFECTING HEAVY OIL RECOVERY IN THE MIDCONTINENT}

\section{BACKGROUND}

Thermal recovery of heavy oil has been tested since the early 1960s in the Cherokee Basin and other parts of the Midcontinent, as this was one of the original areas where numerous companies tested and developed their TEOR technologies. The major TEOR technologies have not changed since the early 1960s although efficiency in steam generation, delivery of steam to the formation (insulated tubulars), reservoir heat management and treatment of emulsions in produced fluids have significantly improved. The technology used in the field tests in the Midcontinent by many of these early operators is an unrefined version of current technology.

In select locations throughout the world, steamflooding technology and resulting oil production have flourished. In the United States, thermal oil recovery accounts for $6 \%$ of total domestic oil production and $76 \%$ of all oil produced by enhanced oil recovery methods (Moritis, 1990). Although TEOR provides needed crude oil and jobs for the economy, it can impact both air and water quality. Adverse impacts on the environment can, however, be mitigated by careful management of standard oil field practices during TEOR process implementation. Previous heavy oil projects and heavy oil reservoirs were analyzed. Most pilot and field-wide TEOR processes have successfully recovered oil from shallow $(<900 \mathrm{ft}$ ) heavy oil reservoirs in western Missouri and eastern Kansas and in south-central Oklahoma $(<2,000 \mathrm{ft})$ heavy oil reservoirs. Most of the TEOR projects analyzed were at depths $<500 \mathrm{ft}$ in the Cherokee and Forest City basins of eastern Kansas and western Missouri.

Previous Midicuntinent heavy oil studies did not consider environmental impacts of implementing EOR processes for heavy oil production. Environmental problems encountered as TEOR processes wert implemented in shallow heavy oil reservoirs were either not reported and/or treated as normal operation problems for the time and process implemented as there were few regulations governing fluid injection. During the decades of the 1970s and 1980s, the public has become more environmentally aware. A review of the environmental factors affecting heavy oil recovery in the Midcontinent has been published covering most of the critical constraints to heavy oil production (Johnson, Olsen and Sarathi, 1991). Environmental Aspects of Heavy Oil Recovery by Thermal EOR Processes has been reviewed by Sarathi, (1991) and a chapter devoted to environmental aspects of cyclic steam and steamflooding has been published by Sarathi and Olsen (1992). 


\section{RESULTS AND DISCUSSION}

Most reservoirs and all confining beds in the Midcontinent are in consolidated sediments. Confining beds for the 4th Deese sand heavy oil reservoir in Sho-Vel-Tum field, Oklahoma are consolidated, but the reservoir is unconsolidated to friable fluvial deltaic sand (Choiu and Murer, 1989). The Oil Creek heavy oil reservoir, Ordovician Period, in Northeast Butterly field, Oklahoma (on primary recovery at approximately 4,000 ft) is an unconsolidated sand reservoir with consolidated confining beds (Butler and McCloud, 1956). Many of these reservoirs are naturally fractured with communication to overlying beds (Hagen, 1972). TEOR operations not only heat the oil and water within the reservoir but also increase the pressure in the reservoir. Increasing reservoir pressure in shallow naturally fractured reservoirs could cause upward migration of injected and reservoir fluids into shallower formations and to the surface along fractures. Therefore, natural fracturing may present environmental problems when TEOR processes are implemented. Poorly plugged old wells, natural fracturing, vertical communication between oil reservoirs and underground aquifers, and impact on air quality are a few of the environmental factors under consideration that may limit production of the Midcontinent heavy oil resources. These factors contribute substantially to the cause for poor economics of TEOR in many Midcontinent heavy oil reservoirs that already suffer from low original oil in place and depositional compartmentalization problems.

Steam TEOR process implementation in a naturally fractured reservoir has the potential for causing damage to subsurface and surface sources of drinking water and/or soils on the surface. Carmel Energy Company implemented their patented Vapor Therm TEOR process in the Carlyle Pool near Iola, Allen County, Kansas, and the Eastburn field, Vernon County, Missouri. In the Carlyle Pool pilot project, the Bartlesville sandstone reservoir was at a depth of 870 to $875 \mathrm{ft}$. Steam and flue gas were injected into the reservoir at an average pressure of $850 \mathrm{psig}$ and an average temperature of $460^{\circ}$ to $500^{\circ} \mathrm{F}$. In the Eastburn field, the Eastburn sandstone is at a depth of 104 to $110 \mathrm{ft}$. Steam and flue gas were injected into the reservoir at an average pressure of 100 to $300 \mathrm{psig}$ and an average temperature of $550^{\circ}$ to $700^{\circ} \mathrm{F}$. No upward migration of injected or reservoir fluids has been reported in literature from these tests, but injection of steam, flue gas, water, or chemicals for EOR may migrate upward along natural fractures to shallower formations or the surface and cause fracturing when injected above formation fracture pressure (Netzler, 1990; Sperry, 1981; Sperry, Young and Poston, 1980; Sperry, Young and Poston, 1979).

A pilot waterflood project was implemented in Burbank Field, Osage County, Oklahoma (a light oil field) during the early 1950s (Hagen, 1972; Hunter, 1956). The reservoir depth is greater than 3,000 ft. Injected water migrated upward along natural fractures in the Burbank sandstone (the waterflood reservoir) that were connected with natural fractures in the overlying shale confining bed into the Stanley Stringer sandstone oil reservoir. Wells more than a mile to the 
northeast from the pilot project in the Stanley Stringer responded to the waterflood. Wells to the southwest, not in the pilot project, also responded to the waterflood. Natural fractures in the Burbank Field area are identifiable by aerial photographs and by observation on the surface. The pilot project ended when the operators recognized the migration of injected water (Hagen, 1972). In this case, contamination of underground aquifers by injected water migration up natural fractures was not reported, but such migration could occur in shallow naturally fractured reservoirs.

In consolidated sediments of the Midcontinent, migration of injected steam, flue gas, hot oil, hot water, and/or chemicals is likely to occur because of natural vertical fractures. Fracture patterns may be seen on the surface, in aerial photographs, on gravity surveys, or aeromagnetic surveys prior to process implementation (Johnsgard, 1988). The best method for identification of surface fracture patterns that are commonly representative of subsurface fracture patterns is through the use of aerial photographs or Landsat photographs. Figure 2.53, Chapter 2, is a graphic display of lineament traces (surface faults and/or fractures) plotted from Landsat photographs (Cooley, 1984). There are two sets of lineament traces, the primary set is oriented northeast-southwest, and the secondary set is oriented northwest-southeast. Landsat photographs and lower level aerial photographs can be used to identify fractures on the surface over an oil reservoir prior to process selection and implementation. Figure 2.54 is a graphic display of lineament traces from gravity surveys for the State of Kansas (Johnsgard, 1988; Lam, 1987). These lineaments represent faulting on a large scale on Pre-Cambrian basement rock. Note that if the scale of the map of these lineaments were on the same scale as that of Fig. 2.53 the lineaments would be farther apart. Figure 2.55 is a graphic display of lineament traces from aeromagnetic surveys (Johnsgard, 1988; Yager, 1983). These are similar to those of Fig. 2.54 (Johnsgard, 1988; Lam, 1987) large-scale faulting on Pre-Cambrian basement rock. Some surface fractures over Midcontinent oil fields may be easily seen by visual inspection of stream banks and unplowed fields. Driving and/or walking over a site that has been selected for EOR process implementation can identify natural fracturing or faulting that are potential point sources for migration of injected and reservoir fluids or gases.

Oil and gas exploration and exploitation started in the Midcontinent shortly after Colonel Drake's oil discovery in Pennsylvania during the 1850 s. Prior to the end of World War II and as late as the late 1960), there were many states in which there were no state or federal laws regulating groundwater protection during oil and gas exploration, production, and/or well abandonment (plugging). In many cases, wells were plugged with wooden fence posts or abandoned without any type of plug, just an abandoned hole. During the early years of the 20th century (prior to World War II) plugging wells with a fence post prior to abandonment was an accepted practice. Many wells were abandoned without any type of plug to prevent upward 
migration of saline water, natural gas, or oil. Modern plugging laws require cement plugs for protection of subsurface and surface drinking water aquifers. Unidentified or unknown improperly plugged wells on a lease where an enhanced oil recovery process will be implemented are a liability that will cause environmental complications as pressure is restored to the reservoir. When an operator is planning TEOR process implementation in the Midcontinent area, a thorough investigation is necessary, with documentation, to try to locate all old abandoned wells, using modern plugging procedure, and plug them to prevent surface and subsurface contamination.

At present, California has air quality standards that are more stringent than those of the U.S. Environmental Protection Agency (EPA). The environmental aspects of heavy oil recovery by thermal EOR processes has been reviewed by Sarathi (1991) where California and EPA standards effecting thermal recovery are reviewed. Many states are following California's example as a role model for environmental protection by enacting similar legislation. California air emission standards imposed on steam generators in the Midcontinent may limit the amount of heavy oil recovered by TEOR because of increased production costs required for compliance. A typical TEOR project in California uses steam generators smaller than 250 million Btu/hr and falls into the catch-all emissions category, emission rate not to exceed 250 tons/year. Table 7.1 gives the typical emissions from oil-fired steam generators of different sizes burning 1.09\%-sulfur fuel (Sarathi, 1991). Enactment of California air emission standards in the Midcontinent may prevent use of lease crude oil and diesel for fuel to fire steam generators, thereby adding cost to the process to purchase cleaner natural gas for steam generation. Steam generation by natural gas as fuel may add cost, not uecause natural gas will cost more, but because the cost of building a pipeline could render the profuced heavy oil uneconomical.

TABLE 7.1. - Typical emissions from an oil-fired steam generator

\begin{tabular}{|c|c|c|c|c|c|c|c|c|c|c|}
\hline \multirow{2}{*}{$\begin{array}{l}\text { Approximate } \\
\text { rated output } \\
\left(10^{6} \mathrm{Btw} / \mathrm{hr}\right)\end{array}$} & \multirow{2}{*}{$\begin{array}{c}\text { Typical } \\
\text { daily fuel } \\
\text { consumption } \\
\text { (bbl/day) }\end{array}$} & \multirow{2}{*}{$\begin{array}{c}\text { Typical } \\
\text { yearly operating } \\
\text { schedule } \\
\text { (days) }\end{array}$} & \multicolumn{4}{|c|}{$\begin{array}{c}\text { Emissions } \\
(\mathrm{lb} / \mathrm{b} \mathrm{b} \text { (fuel) }\end{array}$} & \multicolumn{4}{|c|}{$\begin{array}{c}\text { Emissions } \\
\text { (tons/year) }\end{array}$} \\
\hline & & & $\mathrm{SO}_{2}{ }^{1}$ & $\mathrm{NO}_{2}$ & Particulale & $\mathrm{HC}$ & $\mathrm{SO}_{2}{ }^{1}$ & $\mathrm{NO}_{2}$ & Particulate & $\mathrm{HC}$ \\
\hline 5 & 16 & 365 & 7.2 & 2.5 & 0.7 & 0.1 & 21 & 10.3 & 2.9 & 0.43 \\
\hline 10 & 50 & 292 & 7.2 & 2.5 & 0.7 & 0.1 & 52.6 & 18.3 & 5.1 & 0.73 \\
\hline 20 & 115 & 292 & 7.2 & 2.5 & 0.7 & 0.1 & 120.9 & 42 & 11.8 & 1.60 \\
\hline 50 & 210 & 292 & 7.2 & 2.5 & 0.7 & 0.1 & 220 & 76.7 & 21.5 & 3.07 \\
\hline
\end{tabular}

\footnotetext{
${ }^{1}$ Assuming use of fuel containing 1.09 wt $\%$ sulfur.
} 
Disposal of hot produced water could present permit and disposal problems. Injection of hot water into underground formations would not, in itself, be a problem, but the hot water may contain dissolved chemicals that are highly corrosive to the casing in disposal wells. If the produced water does contain dissolved corrosive chemicals, casing in producing oil wells could be at risk for causing contamination to underground and surface sources of drinking water through casing failure. Corrosion inhibitors could help to prevent problems in producing wells. Produced water could also be filtered and recycled as steam, cutting the cost of steam generation. Carmel Energy reported that water for steam generation was not filtered in its process (Sperry, 1981). Precipitation of scale on production casing could cause plugging problems on perforations in producing wells. Acid may take care of precipitation problems, but it could also cause problems for disposal of effluent.

Injected high temperature flue gas, dominantly carbon dioxide and carbon monoxide, may cause corrosion in injection well casing. Corrosion of injection well casing could ultimately result in casing failure and contamination of underground and/or surface sources of drinking water. Hot flue gas and steam may react chemically, again causing corrosive chemicals that would ultimately cause casing failure and contamination of subsurface and surface waters. Hot flue gas could also be an air pollutant by escaping to the atmosphere with small amounts of natural gas during production operations. Emission of air pollutants through TEOR process implementation and production could hasten enactment of more stringent air quality laws. Injection and production systems should be designed to prohibit corrosion, scale formation, and emission of air pollutants.

The Vapor Therm process, implemented by Carmel Energy, injected flue gas along with steam into the Bartlesville sandstone reservoir in its Carlyle Test, Allen County, Kansas. Carmel Energy claimed that the Bartlesville sandstone reservoir had permanent improvement in reservoir permeability at the end of the test (Sperry, 1981; Sperry, Young and Poston, 1980; Sperry, Young and Poston, 1979). This Cherokee Group sandstone reservoir is similar to other fluvialdominated deltaic sandstone reservoirs in the group. Cements are commonly silica and calcite, with kaolinite and chlorite the dominant diagenetic clays (Bradshaw, 1985). Flue gases injected into the reservoir are dominantly carbon dioxide and carbon monoxide from burning diesel in the Vapor Therm process. When these hot gases (as high as $700^{\circ} \mathrm{F}$ ) combine with steam and hot water injected into the reservoir, carbonic acid is formed. If sulfur is present in the diesel fuel burned for firing the Vapor Therm steam generator, sulfurous acid will be formed when combustion gases react with the hot steam and water. These hot acids can dissolve cements in the reservoir, cause corrosion of tubular goods and equipment, and create disposal problems on the surface. If the reservoir is naturally fractured, corrosive liquids and gases can cause contamination of subsurface drinking water and/or the surface. 
The permanent permeability improvement in the Carlyle Test mobilized sand grains causing them to be produced along with the heavy oil (Sperry, 1981; Sperry, Young and Poston, 1980; Sperry, Young and Poston, 1979). Prior to the test, the Bartlesville sandstone was consolidated. Carmel Energy also implemented the Vapor Therm process in Eastburn Field, Vernon County, Missouri (Sperry, Young and Poston, 1979; Bradshaw, 1985). In Eastburn Field, fine sands and clays were mobilized causing them to be produced with heavy oil when this process was implemented (Sperry, Young and Poston, 1979; Bradshaw, 1985). The pilot projects implemented in Sho-Vel-Tum Field, Carter County, Oklahoma produced unconsolidated sand from the Fourth Deese sand reservoir (Butler and McCloud, 1956).

The United States Department of Energy conducted an in Situ combustion project at Bartlett, Kansas in a shallow ( $<200 \mathrm{ft}$ ) Bartlesville sandstone heavy oil reservoir. The project encountered many mechanical problems which caused the project to be conducted intermittently in the late 1970s and early 1980s. During periods when combustion may have occurred, pressure was difficult to maintain because of suspected migration to the surface along natural fractures in an off pattern location (Porter, 1991). The probability of natural fractures connecting a shallow heavy oil reservoir with the surface may have been identified by an environmental assessment in this and other projects prior to process implementation but at the time of most TEOR pilot tests were being conducted in the Midcontinent, the 1960's and 1970's, environmental assessments were not required.

The Fourth Deese sand heavy oil reservoir was unconsolidated prior to process implementation (Choiu and Murer, 1989). When these pilot tests were conducted, disposal of sand, clays, and other very-fine and fine-grained reservoir clastic materials coated with heavy oil was not an environmental concern. In today's environmentally conscious petroleum industry, produced reservoir rock coated with heavy oil is a major disposal problem. Unconsolidated reservoir sand coated with oil is produced along with heavy oil in the Northeast Butterly field. The oil coated sand is bioremediated on the producing property. Bioremediation of heavy oil coated reservoir rock at the surface location is a workable solution to the disposal problem of this material (Butler and McCloud, 1956; Phillips and Whitt, 1983).

The refineries in the Midcontinent (Kansas, Missouri, Oklahoma) were not designed to process significant volumes of heavy oil because they have little coking capacity (Olsen and Ramzel, 1991). If heavy oil were made available from outside the region, the refineries would quickly lose their efficiency as the ability to process even light oil because processing the heavy ends limits their entire operation. Air quality could be affected because of sulfur content of some heavy oil is typically much high than light sweet crude that Midcontinent refineries were designed to process thus causing expensive alterations to existing refineries to gain the capability to increase 
heavy oil refining capacity. Disposal problems will be experienced with catalysts contaminated with heavy metals from processing larger quantities of heavy oil.

Early in the process of determining the feasibility of TEOR for a specific site, the combined resources of engineering, geological, process design, and environmental assessment must be coordinated to determine the impact of process implementation and the effect on economic feasibility of the project. In today's safety and environmentally conscious petroleum industry, the environmental problems associated with shallow aquifer contamination or leakage to the surface are unacceptable/uneconomic risks. During the 1950s and 1960s, undocumented abandoned wells were found when fence posts were launched or steam erupted shortly after TEOR processes were implemented (personal communication with numerous previous employees, all of whom wished to remain anonymous for personal reasons, 1990-1991). When an operator is planning TEOR process implementation in the Midcontinent area, a thorough investigation is necessary, with documentation, to try to locate all old abandoned wells for the prevention of surface and subsurface contamination because repressurization of the reservoir will sometimes dramatically demonstrate (blowout) where communication exists.

\section{BIBLIOGRA PHY}

Bradshaw, D. T. Geologic Variables Influencing Production in Eastburn Field, Vernon County, Missouri [MS Thesis], Colorado State University, 1985.

Butler R. and S. D. McCloud. Northeast Butterly Pool - Case Histury. J. Pet. Tech., Feb. 1956, pp. 23-26.

Choiu, R. C. S. and T. S. Murer. Cyclic Steam Pilot in Gravity Drainage Reservoir. Pres. at the 64th Annual Technical Conference and Exhibition of the SPE, San Antonio, TX, October 811, 1989. SPE paper 19659.

Cooley, M. E. Linear features determined from Landsat imagery in western Kansas: U.S. Geol. Survey, Open-file Rept. 84-241, 1984, 1 sheet, scale 1:500,000).

Hagen, K. B. Mapping of Surface Joints on Air Photos Can Help Understand Waterflood Performance Problems at North Burbank Unit Osage and Kay Counties, Oklahoma [M.S. Thesis], University of Tulsa, 1972.

Hardy, W. C. and J. D. Raiford. In Situ Combustion in a Bartlesville Sand - Allen County, Kansas. In: Sun Oil Company, 1972.

Hunter, Z. Z. North Burbank Unit Water Flood, API Drilling and Production Practices, 1956, pp. 262-273.

Johnsgard, S. K. The Fracture Pattern of North-central Kansas and Its Relation to Hydrogen Soil Gas Anomalies Over the Midcontinent Rift System [MS Thesis], University of Kansas, 1988. 
Johnson, W. I., D. K. Olsen and P. S. Sarathi. Environmental Factors Affecting Heavy Oil Recovery in the Midcontinent, presented at 1991 Eastern Oil Shale/Tar Sands/Heavy Oil Symposium, Lexington, Kentucky, November 13-15, 1991, pp. 167-173. Also in Fuel, v. 71, December 1992, pp. 1493-1498.

Lam, Chi-Kin. Interpretation of state-wide gravity survey of Kas.sas: [Ph.D], University of Kansas, Lawrence, 1987, 213 p., (available as Kansas Geological Survey, Open-file Rept. 87-1).

Miller, J. S. and K. L. Spence. In Situ Combustion Project at Bartlett, Kansas. In: U.S. Dept. of Energy, Report No. DOE/BETC/RI-83/3. 1983.

Moritis, G. $\mathrm{CO}_{2}$ and $\mathrm{HC}$ Injection Lead EOR Production Increase, Biennial EOR Production Report, Oil \& Gas J., Apr. 23, 1990.

Netzler, B. W. Heavy-Oil Resource Potential of Southwest Missouri. In: Missouri Department of Natural Resources, Division of Geology and Land Survey, 1990.

Personal communication with staff of Carmel Energy, September 1990.

Personal Communication with Roy Porter, independent consulting petroleum engineer, July 1991.

Phillips, F. L. and S. R. Whitt. Success of Openhole Completion in the Northeast Butterly Field. Presented at the Soc. Pet. Eng. 1983 Production Operation Symposium, Oklahoma City, OK, Feb. 27-Mar. 1, 1983. SPE paper 11555.

Sarathi, P. S. Environmental Aspects of Heavy Oil Recovery by Thermal EOR Processes, presented at Society of Petroleum Engineers, Western Regional Meeting, Long Beach, CA, March 20-22, 1991. Published in J. Pet. Tech., v. 43, No. 6, June 1991, pp. 662-672.

Sarathi, P. S. and D. K. Olsen. Practical Aspects of Steam Injection Processes-A Handbook for Independent Operators, U. S. Department of Energy Report No. NIPER-580, August 1992.

Sperry, J. S., F. S. Young and R. S. Poston. Development and Field Testing of a Process for Recovering Heavy Crude Oil in the Carlyle Pool-Allen County, Kansas Using the Vapor Therm Generator. In: Carmel Energy, Inc., U. S. Department of Energy Report No. DOE/BETC-2880-1. 1980.

Sperry J. S., F. S. Young and R. S. Poston. Field Testing of the Vapor Therm Process in the Eastburn (Cherokee) Field Vernon Co. Missouri. Fifth DOE Symposium on Enhanced Oil \& Gas Recovery \& Improved Drilling Technology. Tulsa, OK: The Petroleum Publishing Company, 1979: 1/1-1/16.

Sperry, J. S., Heavy-oil recovery system completes three field tests in Mid-Continent region, Oil \& Gas Journal, July 27, 1981.

Yarger, H. L., 1983, Regional interpretation of Kansas aeromagnetic data: Kansas Geological Survey, Geophys. Ser. 1, 35 p. 


\section{CHAPTER 8}

\section{REFINING AND TRANSPORTATION FACTORS AFFECTING HEAVY OIL RECOVERY IN THE MIDCONTINENT}

\section{RESULTS AND DISCUSSION}

The Midcontinent refineries were not designed for processing heavy crude oil. They were designed to process predominantly sweet and some sour light crude oil which is typical of the Midcontinent. Principal products from these refineries are motor fuels which have a high profit margin, high value, and high demand and are easily obtainable from light crudes. These refineries have little capacity to produce asphalt or petroleum coke which are in low demand, have low value and are low margin products. Coking is a means of disposing of products that limit a refiners ability to process lighter ends to obtain high margin products. The capabilities of the areas current operating refineries are listed in Table 8.1, which is derived from Oil \& Gas Journal's annual listing of refinery capabilities (Thrash, 1991). Missouri does not have a refinery and to compensate for lost revenue imposes a storage tax on hydrocarbons stored within the state.

Nine aging or small local refineries in the Midcontinent area closed during the 1970s and early 1980s. Recently, 1991-92, three additional refineries closed or closed significant sections of their refinery (Farmlands, Phillipsburg, Kansas, refinery 26,400 BO/CD; Coastal's El Dorado, Kansas, refinery 30, $400 \mathrm{BO} / \mathrm{CD}$; and Sun refining in Tulsa with 85,000 BO/CD which suspended motor fuel production). This was due to poor rate of return on investment, projected high costs to install equipment to meet environmental standards and comply with higher product quality standards. Nationwide the loss in refining capacity was made up by larger refiners who undertook expansion of scale, implementation of environinental controls and improvement in efficiency to maintain their competitive edge. Nationally, higher efficiency and less down time have allowed higher total throughput in spite of the loss in the number of refineries. In the Midcontinent (Kansas and Oklahoma) the distillation capacity (BO/calendar day) has declined, the 1988 capacity is only $73 \%$ of the 1977 capacity and $62 \%$ of the 1992 capacity, Table 8.2 .

The national trend in refining is shown in Figure 8.1 where currently there is a total of 190 refineries with a refining capacity of 16,300,000 BCPD in the United States (Olsen and Ramzel, 1991). States with the largest refining capacities are Texas, with the capacity of 4,000,000 BOPD, and California, with the capacity of 2,500,000 BOPD. From the mid 1970s to 1980s, upstream business was good while the margin on domestic refining was weak. The rising oil prices of the 1970s and early 1980s provided funds for not only oil production facilities but also for overbuilding refinery capacity, which coupled with high oil prices lead to very weak refining 


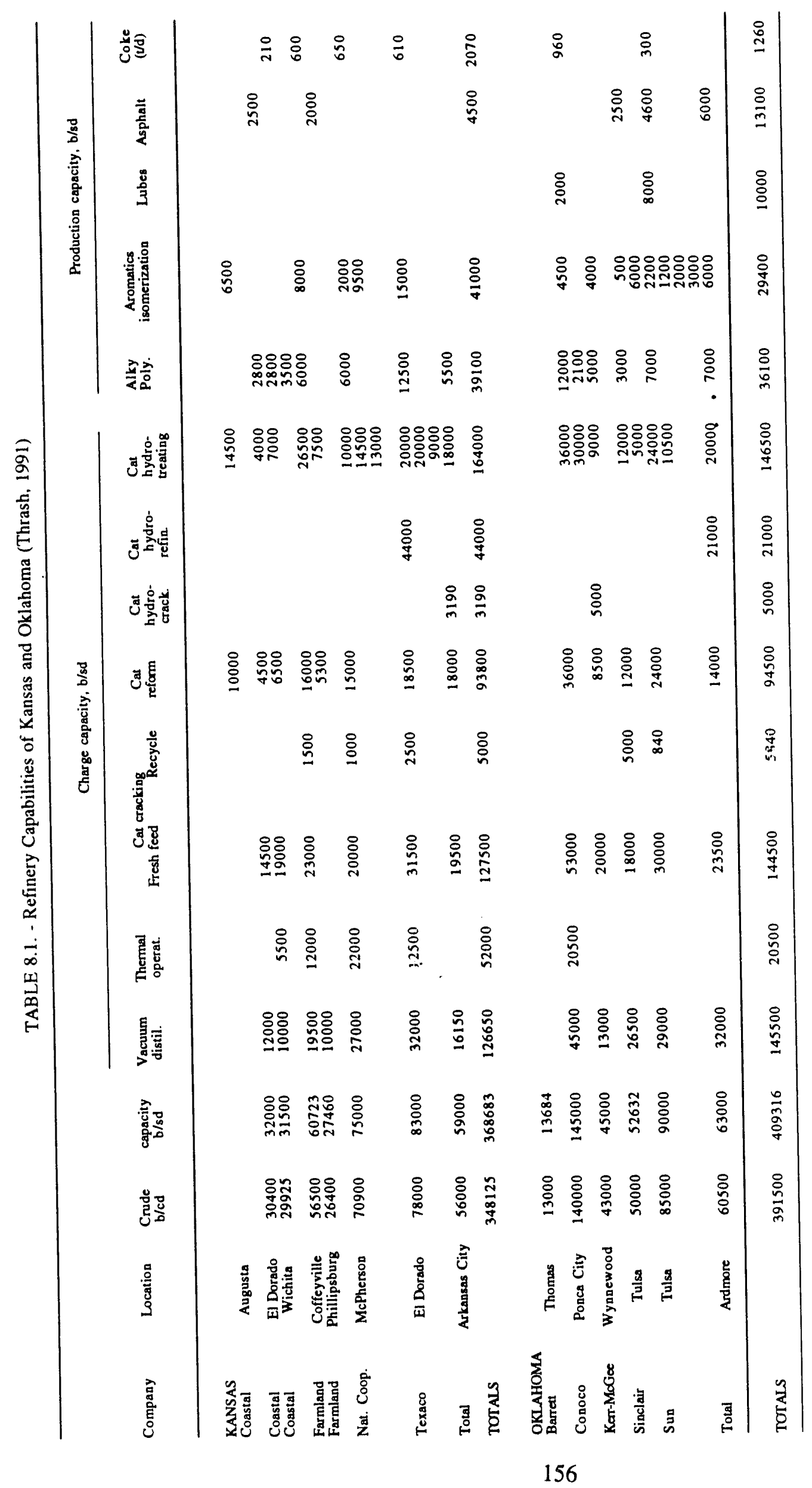


TABLE 8.2. - Historical refining trend in the Midcontinent and surrounding area (Kansas Inc., 1990)

\begin{tabular}{lrrrrrrrr}
\hline & \multicolumn{3}{c}{ Refineries } & & & \multicolumn{3}{c}{$\begin{array}{c}\text { Distillation Capacity } \\
\text { (BO/Calendar Day) }\end{array}$} \\
\cline { 2 - 3 } \cline { 6 - 8 } & 1977 & 1988 & $1991^{\mathrm{a}}$ & & 1977 & 1988 & $1992^{\mathrm{a}}$ \\
\hline Kansas & 11 & 8 & $\mathrm{~d}_{6}$ & & 454,000 & 344,000 & $\mathrm{~d}_{296,425}$ \\
Illinois & 11 & 6 & 7 & & $1,182,000$ & 921,000 & 948,500 \\
Texas & 49 & 31 & 31 & & $4,193,000$ & $4,058,000$ & $3,882,200$ \\
Oklahoma & 12 & 6 & 6 & & 547,000 & 388,000 & $c_{324,500}$ \\
\hline
\end{tabular}

a Updated data from Oil \& Gas J., December 23, 1991.

b Reduced volume due to closure of Phillipsburg refinery.

c Reduced volume due to partial closure of Sun refinery in Tulsa.

d Reduced value due to closure of El Dorado refinery.

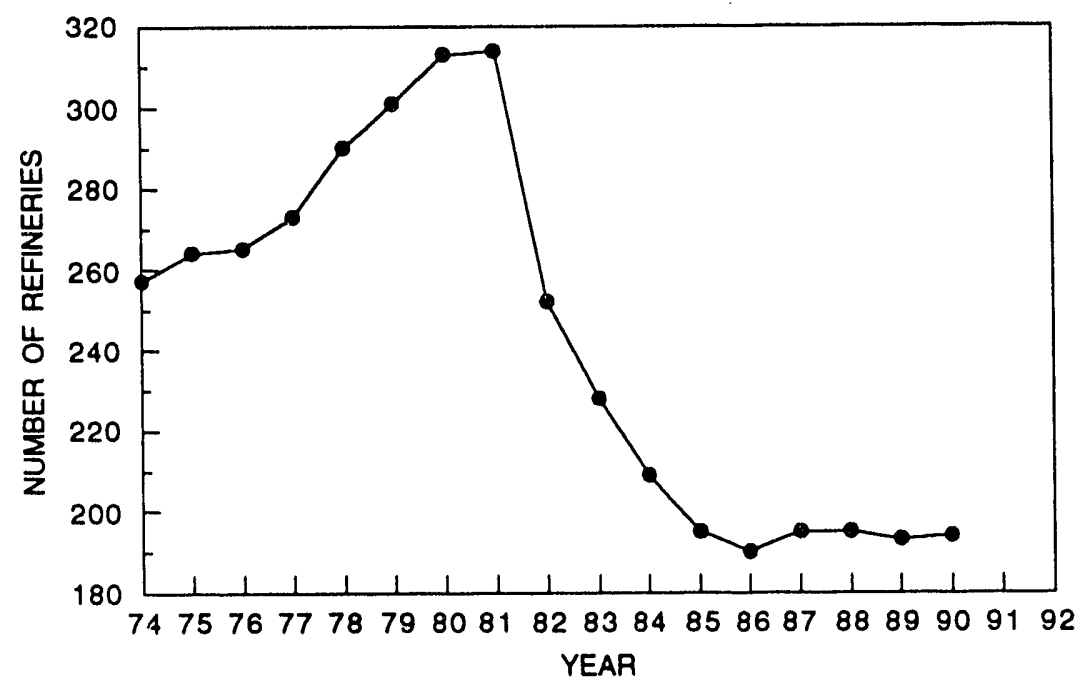

FIGURE 8.1. - Total number of U.S refineries

margins. Refining in the Midcontinent fared worse from the closure of marginal refineries (loss of refineries) and investment in new refining capacity than the U.S. as a whole. With the decline in oil prices starting in 1981 and the oil price collapse in 1984, the economics of downstream operations became increasingly important. In the last half of the 1980 s, the drop in crude oil prices coupled with increasing demand for refined products caused higher refinery capacity utilization in the remaining refineries and higher margins. The trend for stronger demand for gasoline and weaker demand for fuel oil led to increased margins for refineries designed to convert their fuel oil 
to lighter distillates, which is typical of the remaining Midcontinent refineries (Kansas Inc., 1990). There are fewer Midcontinent refineries because Midcontinent refineries were:

1. historically smaller resulting in low scale economics,

2. relative old and therefore had high operating costs,

3. had lower than average capabilities to convert heavy, high sulfur crudes to light products, and

4. are losing their natural location advantage due to faster growth in other states and the shift in population to other consuming regions. The prices and margins were consequently lower because refined products have to be transported further distances to consuming regions of the United States.

Refinery operations with heavy oil are primarily limited by economic constraints (price of crude and market price of products) and quantity and quality of heavy oil that a refinery can process. The main refining constraint is the lower profit margin resulting from refining heavy versus light crude oil (Wright Killen refinery Margins, Oil \& Gas J. Weekly statistics section). It takes a larger investment and a higher operating cost per barrel to refine a barrel of heavy oil. This is chiefly due to heavier oils having higher molecular weight, lower hydrogen to carbon ratio, and higher metals and sulfur content due to a much higher proportion of difficult to process "tail-ends" (i.e. - $>1,050^{\circ} \mathrm{F}$ ). In general, heavy oil lowers throughput of refineries relative to light oil, increases catalyst cost, and requires more frequent and longer turnaround times. In addition, heavy oil is more difficult to transport in that it lowers pipeline throughput, requires additional heating costs, and has more cold-weather, precipitation, and incompatibility related handling problems than light oil.

Upgrades to refineries in the Midcontinent are expected to allow remaining refineries to remain competitive for processing light crudes but investment in facilities to process heavy ends, catalytic (cat) cracking and coking. are not anticipated. There is not a strong enough demand for the investment and the rate of return would be low. New, stricter environmental restrictions and the decreasing use of fuel oil have prompted U.S. refiners to use low metal oils as feed stock for making gasoline and light products. Total world cat cracking represents $17 \%$ of total capacity for refining. However, in the U.S. with its high gasoline usage, approximately one-third of United States refining conversion capacity is by cat cracking, and nearly $30 \%$ of the total world cat cracking capacity is in three states: Texas, California, and Louisiana.

The Midcontinent has a well established, although aging, light oil and refined product transportation network. The storage facilities, especially at Cushing, Oklahoma are an asset to the region in allowing switching between refinery feeds and provides a stockpile of oil that can be shipped to refineries throughout the country (Koen, 1990). No expansion of pipelines are anticipated except locally from the limited thermal operations being conducted along fault blocks on 
the north side of the Arbuckle Mountains in unconsolidated sandstone reservoir of South Central Oklahoma. In this case, pipeline capacity in the surrounding area to a refinery will be available because of declining light oil production in the region.

\section{BIBLIOGRAPHY}

Thrash, L. S . Annual Refining Survey. Oil \& Gas J., v. 89, No. 11, Mar. 18, 1991, p. 84.

Rhodes, A. K. Worldwide Refining Report. Oil \& Gas J., v. 89, No. 51, Dec. 23, 1991, p. 33.

Wright Killen Refinery Margins In the Statistics section of Oil \& Gas J., v. 89, No. 32, Aug. 12, 1991, p. 98 and weeks thereafter.

Kansas Inc. Strategic Analysis of the Oil and Gas Industry in Kansas, Arthur D. Little, Inc., Cambridge, Mass., April 1990, pp. 13-17.

Koen, A. D. Inland demand for crude will strain capacity for U. S. Gulf Coast-Midwest Lines, Oil \& Gas J., v. 88, No. 52, Dec. 24, 1990, pp. 14-16.

Olsen, D. K. and E. B. Ramzel. Heavy Oil Refining and Transportation: Effect on the Feasibility of Increasing Domestic Heavy Oil Production, to be presented at 1991 Eastern Oil Shale/Tar Sands/Heavy Oil Symposium, Lexington, Kentucky, November 13-15, 1991. Also in Fuel, v. 71, December 1992, pp. 1391-1401. 


\section{CHAPTER 9 \\ CONCLUSIONS AND RECOMMENDATIONS}

\section{CONCLUSIONS}

The geology of the Midcontinent controls the oil production in the Midcontinent. The billions of barrels of heavy oil reported in the Cherokee Basin were speculative and are not supported. Many individuals considered heavy oil as $<25^{\circ}$ API and there are at least twice the number of reservoirs $20^{\circ}$ to $25^{\circ}$ API gravity as $10^{\circ}$ to $20^{\circ}$ API. NIPER's initial heavy oil database that included reservoirs up to $25^{\circ}$ API gravity indicates that a significant oil volume exists in the $20^{\circ}$ to $25^{\circ}$ API gravity range in the Midcontinent. The broader definition of heavy oil and the belief that many of the Pennsylvanian heavy oil sands were "blanket sands" led to the overestimation. NIPER's analysis of each geological time period in the three states indicates that although these states contain heavy oil $\left(10^{\circ}\right.$ to $20^{\circ}$ API) listed as resources, heavy oil recovery from lowpermeability, fluvial deltaic, consolidated sandstone reservoirs such as those of the Cherokee and Forest City Basin, with current technology including that of horizontal wells, would be marginal or uneconomic. Only a small fraction of the resource is amenable to recovery. Studies within the past two decades show that the reservoirs were widely distributed with many being of fluvial deltaic in origin and having undergone extensive diagenesis. For the most part, the reservoir rock is highly compartmentalized, has complex internal architecture and is fractured. Previous TEOR operations (cyclic steam, steamflooding, steam and combustion gas, and in situ combustion) show oil production higher than primary. The oil recovery process worked but the geologic environment (internal architecture of the reservoir) limited economic success.

Many operators learned from the early TEOR pilots and found reservoirs which are thicker, are unconsolidated or friable, have more oil per acre, have more oil per acre foot, and thus are more amenable to economic heavy oil production. The steeply dipping, high-permeability ( $>500 \mathrm{mD}$ ), unconsolidated sands that are on the north side of the Arbuckle mountains in southcentral Oklahoma produce heavy oil by primary as well as by thermal methods. It is from these more massive unconsolidated or friable sandstone formations that heavy oil has the best potential for being economically produced in the Midcontinent. In these unconsolidated or friable sands, TEOR can supply heat to reduce oil viscosity and gravity drainage can assist oil recovery. The recovery from or estimation of the volume of the resource of heavy oil in carbonate reservoirs of central and western Kansas has not been adequately documented. Based on correlation with other carbonates in the world that produce heavy oil, this area is not anticipated to contribute substantial economically recoverable heavy oil.

The refineries in the Midcontinent were not designed to process heavy oil. They are aging small to medium volume, light, sweet crude oil refineries designed to process locally produced oil. 
Although many older, smaller refineries have closed during the last decade, more refinery abandonments are anticipated within the next decade due to economy of scale, increased pollution control regulations, demand for cleaner products, declining local light sweet oil production, and the fact that these plants have older, less efficient units that do not allow for an adequate economic rate of return. The pipeline network of the Midcontinent region can dilute small volumes of heavy oil with light crude but only on a limited scale because there are no heated pipelines in the network.

The following conclusions are based on the results of integrated analyses of indirect evidence in state geological survey, oil and gas board, USGS, and US DOE reports, unpublished theses, published technical reports, and personal conversations. Data on reservoir characterization were interpreted based on integrated analyses of production and reservoir data and conversations with operators about results of infill drilling.

1. Economic thermal heavy oil production has been shown for the unconsolidated, steeply dipping, high permeability reservoirs of south central Oklahoma where the oil migrated into the reservoir early and extensive diagenesis of the reservoir has not occurred. Stripper production of heavy oil is marginal in most of the Midcontinent since oil production rates are usually very low.

2. Heavy oil has been shown to be recoverable by thermal processes from shallow thin fluvial deltaic consolidated sandstone reservoirs of the Midcontinent. Fireflooding, steamflooding (drive), cyclic steam, and steam injection processes combined with injection of hot gases (Vapor Therm and others) are successful thermal processes that have been tested in Midcontinent sandstone reservoirs during the last 30 years. However, successful must be qualified, these technologies produced more oil than primary production. With rare exception, these projects were not economic based on their daily oil production rate.

3. Implementation of TEOR processes to recovery heavy oil from thin fluvial deltaic consolidated sandstone heavy oil reservoirs may not be economic. No project looked economic and at the same time was environmentally acceptable.

4. Only a site specific economic/engineering/geologic analysis can determine if the recovery process chosen for a specific reservoir may be economic. A pilot test is required to customize the process to meet site specific constraints and technical and economic feasibility. Integrated engineering and geologic analyses prior to process implementation will improve chances for successful implementation of a thermal process.

5. The most favorable facies for best recovery of incremental heavy oil in consolidated sandstone in fluvial deltaic systems in the Midcontinent is a trough bedded channel-fill facies. Poor heavy oil recovery results from implementing TEOR processes in more compartmentalized, discontinuous bedded, lenticular, upper point-bar, channel-fill sandstone facies. There have been more reservoir quality damaging diagenetic changes, including bedding boundary permeability barriers, in upper facies sandstones than in trough-bedded, lower facies sandstones. Reservoir 
analysis can help to determine where the better geologic facies for process implementation may be located in a reservoir.

6. Fields with old stripper wells, wells with poor casing integrity, poorly plugged wells or unknown wells are liabilities with TEOR processes or recovery processes that significantly increase the reservoir pressure. TEOR requires wells to be properly completed to accommodate heat and pressure. Well spacing must be less than that of compartmentalization (usually less than 1 acre). TEOR well spacing in many unconsolidated sands in California oil fields are drilled on 1-1/4- or 5/8-acre spacing. East Texas Field of East Texas was developed on 1-3/4-acre spacing.

7. Injection pressures that exceed the reservoir fracturing pressure may cause environmental problems at the surface or in the subsurface if injected fluids or formation fluids escape.

8. Development of old fields with horizontal wells must carefully consider the geology and expected oil recovery to justify the increased expenditure. Horizontal wells for heavy oil recovery in the Cherokee Basin do not look economical because of the geology of the reservoir.

9. Neither refining or transportation facilities have adequate capabilities to accommodate significant heavy oil. However, no significant heavy oil development, transportation or refining are anticipated in the Midcontinent.

Of the TEOR project reviewed, the Vapor Therm process applied in Eastburn Field, Vernon County, Missouri, progressed from a field pilot project to full-scale field implementation while most other pilot projects were abandoned at the end of the pilot phase. Stimulation of the Eastburn Field reservoir with steam stopped shortly after the 1985-1986 decline in domestic oil prices. The Mobil TEOR pilot project is successful and may progress to field scale implementation in the 4th Deese sand in south-central Oklahoma and is the only TEOR project currently reported as operating.

No reasons for failure of projects to progress to field scale projects were given in the reports that were reviewed. Economics for heavy oil recovery in the consolidated sands when these processes are implemented will be affected by bottom water in the heavy oil reservoir, depositional compartmentalization, permeability, steam to oil ratio, communications with other formations by naturally occurring vertical fractures, low average daily oil recovery, "thief" zones, etc. Reservoirs analyzed had one or more of these conditions affecting oil recovery which may have influenced operators to implement their process in other types of heavy oil reservoir and in other sedimentary basins containing unconsolidated, often younger sediments. Implementation of TEOR processes in $\operatorname{cool}\left(<75^{\circ} \mathrm{F}\right)$, shallow $(<1,000 \mathrm{ft})$, consolidated reservoirs may cause fracturing in the reservoir rock due to rapid increase in temperature. Heavy oil may be bypassed due to line drive along fractures created in the reservoir by the rapid temperature change $\left(<75^{\circ} \mathrm{F}\right.$ to $\left.>300^{\circ} \mathrm{F}\right)$.

Heavy oil accumulations are found in sandstone and carbonate reservoir rocks from Cambrian through Pennsylvanian in age. In the Cherokee Basin, Forest City Basin, and South 
Central Oklahoma, Cherokee Group fluvial deltaic sandstones dominate as reservoir rock for heavy oil accumulations. Carbonate rocks are the dominate reservoir rock for heavy oil in central and western Kansas. Surface accumulations along sandstone and carbonate outcrops are found in Pennsylvanian and older Paleozoic age rocks in eastern Kansas, western Missouri, and south central Oklahoma. Heavy oil reservoirs exist in the same reservoir rock as light oil and in reservoir rock above or below many light oil reservoirs in fields of eastern Kansas and Oklahoma. Many are not producing or produce heavy oil on a limited basis (during warm weather on primary recovery). The heavy oil in these reservoirs is produced by stripper wells at rates of about 0.3 to a few BOPD. Heavy oil produced on a limited basis may not be reported as heavy oil but commingled with light oil and sold as medium gravity oil.

Fields with heavy oil reservoirs are structural, stratigraphic, and structural-stratigraphic traps. Midcontinent heavy oil reservoirs are in consolidated sandstone and carbonate rocks with consolidated confining beds. Sho-Vel-Tum Field in Oklahoma has consolidated confining beds but the 4th Deese sand heavy oil reservoir is unconsolidated with high permeability. These heavy oil reservoirs in Sho-Vel-Tum Field are more like California heavy oil reservoirs than any other reservoir analyzed in the Midcontinent because of (1) unconsolidated reservoir rock, (2) steeply dipping ( $40^{\circ}$ angle), (3) high porosity (25\%-30\%) and permeability ( 800 to 9,600 mD), (5) high oil saturation after primary production of 50 plus years, (6) thick reservoir ( $<50 \mathrm{ft}$ ), and (6) high peak production by gravity drainage during TEOR application. Other Midcontinent heavy oil reservoirs analyzed where TEOR processes had been implemented were consolidated reservoirs with complex internal architecture.

Depositional compartmentalization in heavy oil reservoirs in Cherokee Basin and Forest City Basin are common in shallow, upper facies fluvial deltaic sandstones of Cherokee, Marmaton, and Missourian groups and limits oil recovery. Upper facies sandstones with depositional compartmentalization are discontinuous (vertically and laterally), multiple stacked lenticular sandstone bodies with bedding boundary permeability barriers that form these compartments. Bedding boundary permeability barriers are formed during diagenesis shortly after burial. Limited, uneconomical quantities of heavy oil will usually be recovered after implementation of TEOR processes because of depositional compartmentalization. Lower facies reservoir rock in this area is more continuous trough bedded sandstone. Lower facies sandstone reservoirs will have higher oil production and recovery than upper facies sandstones. Depositional compartmentalization does not dominate lower facies sandstones in the study area as it does in upper facies sandstones. Each individual company will need to make a determination on economics for each facies based on production costs and company tax structure.

Diagenetic clays and cements (silica and calcareous) dramatically reduce porosity and permeability in reservoir rocks. Cementation of Midcontinent sandstone heavy oil reservoirs, 
except Sho-Vel-Tum Field 4th Deese sandstone reservoir, is a primary difference from sand reservoirs in California, Canada, Indonesia, and Venezuela which are unconsolidated. Diagenetic clays precipitated in the matrix (between and on sand grains) of Midcontinent sandstones, further reducing porosity and permeability of sandstone heavy oil reservoirs. If oil had migrated into Midcontinent sandstone heavy oil reservoirs shortly after burial and prior to diagenetic changes, these heavy oil reservoirs would have been more like those currently developed for TEOR.

Although some people working in EOR process development and implementation consider EOR as a logical extension of primary and secondary recovery processes, EOR is non-traditional application of advanced oil recovery technology. During exploration and development phases of a petroleum reservoir, the traditional approach of reservoir classification by geologic depositional system is one of the more important parameters. Knowledge of geologic depositional systems helps in the placement of wells in the reservoir. Before the reservoir is fully developed, classification of the depositional system becomes less important while production engineers implement traditional programs to maximize oil recovery. Implementation of non-traditional (unconventional) production technology (EOR) to recover incremental oil requires a non-traditional approach for integrated geological, engineering, and process analysis for producing an oil reservoir. Based upon integrated analysis of secondary reservoir and process data, it is concluded that the degree of consolidation, compartmentalization, diagenetic changes, small scale beddingboundary permeability barriers, geologic age of a reservoir, petrophysical properties, flow paths of reservoir fluids, and sweep efficiency are more important factors governing recovery of incremental oil than geologic depositional system. Furthermore, each reservoir is unique requiring an integrated engineering, geologic, process, environmental and economic analysis prior to implementation of EOR.

Environmental problems could be encountered when implementing TEOR processes in Midcontinent heavy oil reservoirs. Disposal of produced reservoir rock coated with oil, air quality, migration of injected gases and fluids along vertical fractures to shallow formations or the surface, and excess injection pressure are some of the environmental problems that could occur. Natural fracturing and depositional compartmentalization of reservoir rock could in effect help to cause environmental problems when the pressure in the reservoir is increased. Natural fractures provide a pathway for injected fluids and gases to migrate. Depositional compartmentalization (internal architecture) limits injection of fluids and gases causing a pressure build-up and fracturing of the formation into shallower zones or the surface.

\section{RECOMMENDATIONS}

1. It is recommended that no field demonstration pilot projects for heavy oil recovery processes be conducted in Midcontinent Pennsylvanian fluvial deltaic sandstones. 
2. The potential for expansion of the heavy oil from the steeply dipping, high-permeability, unconsolidated sands in south-central Oklahoma needs to start with the analysis of the steamflood currently being conducted by Mobil. 


\section{CHAPTER 10}

\section{TABULAR LISTING OF HEAVY OIL RESERVOIR PROPERTIES}

Within the scope of travel and research sources for the study, Table 10.1 lists average reservoir data for major Midcontinent heavy oil reservoirs ( $10^{\circ}$ to $20^{\circ} \mathrm{API}$ gravity inclusive). Due to the size of the resource and the complex geology of the fluvial deltaic reservoirs for the Cherokee Basin and the sparse data on the carbonates of western Kansas, only major reservoirs with $>10$ million barrels OOIP justifies continued research of records to complete the reservoir database for inclusion into the national heavy oil database. Therefore, Table 10.1 is a sparse database. Within the constraints of the study, many of the OOIP values are estimated. The abreviations for lithology are: FDD = fluvial dominated deltaic, Mar Shelf = marine shelf. Cumulative oil production is through the year listed as CUM REC YR, and CUM REC \% is the percent of OOIP recovered through that date. The source of data has been omitted for clarity but is included in the electronic copy of NIPERs heavy oil database which is a more extensive reservoir file for the Midcontinent. Much of the discussion contained in this report was based upon the broader definition of heavy oil being $10^{\circ}$ to $25^{\circ}$ API gravity because many previous analysis failed to define "heavy oil".

The estimated heavy oil-in-place is Missouri, < 100,000,000 bbl; Kansas, < 100,000,000 bbl; and Oklahoma, $<800,000,000 \mathrm{bbl}$. The estimated economically recoverable heavy oil is only a fraction of the oil-in-place, with the Forest City and Cherokee Basin being $<5,000,000 \mathrm{bbl}$ and south-central Oklahoma being $<40,000,000 \mathrm{bbl}$. 


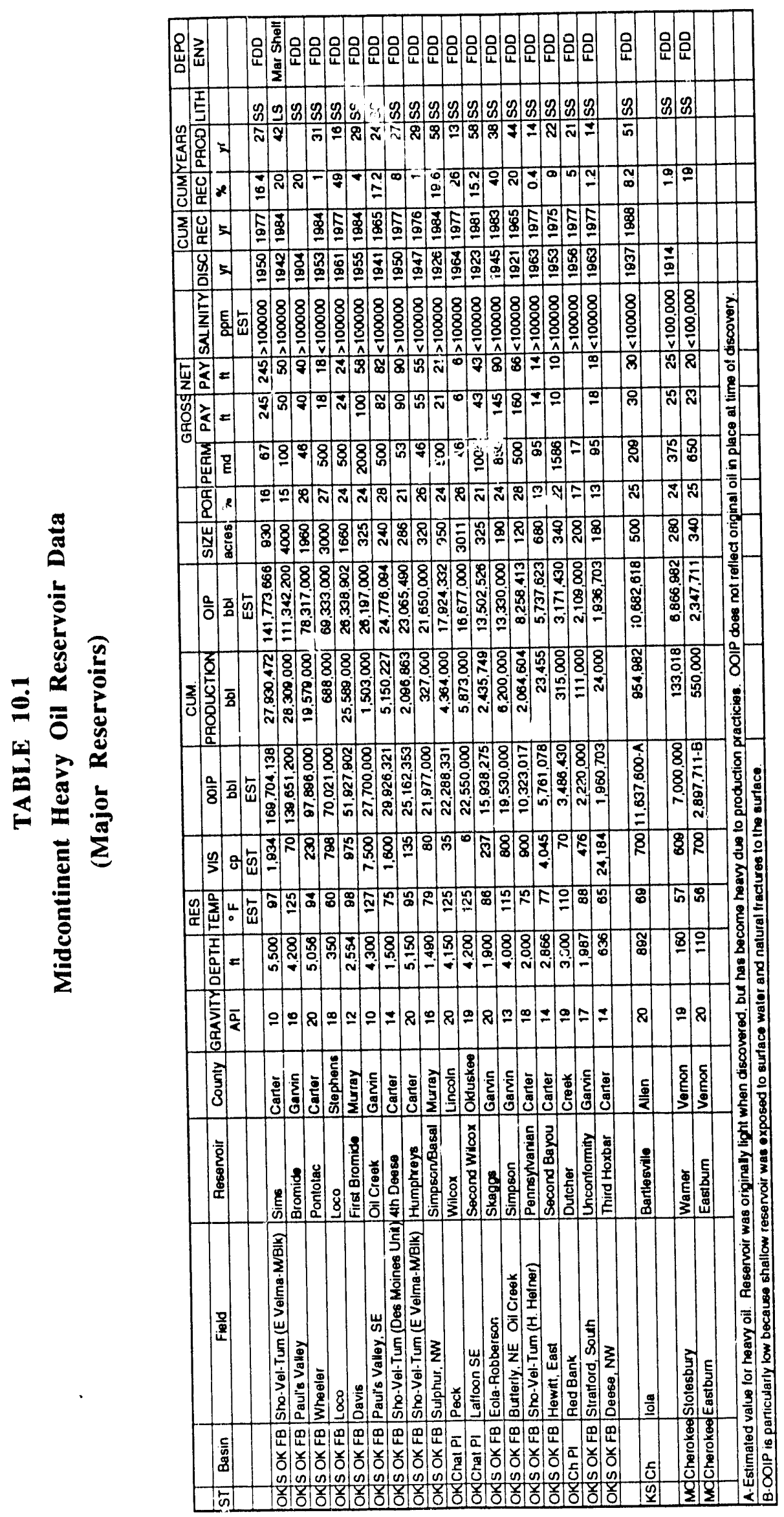



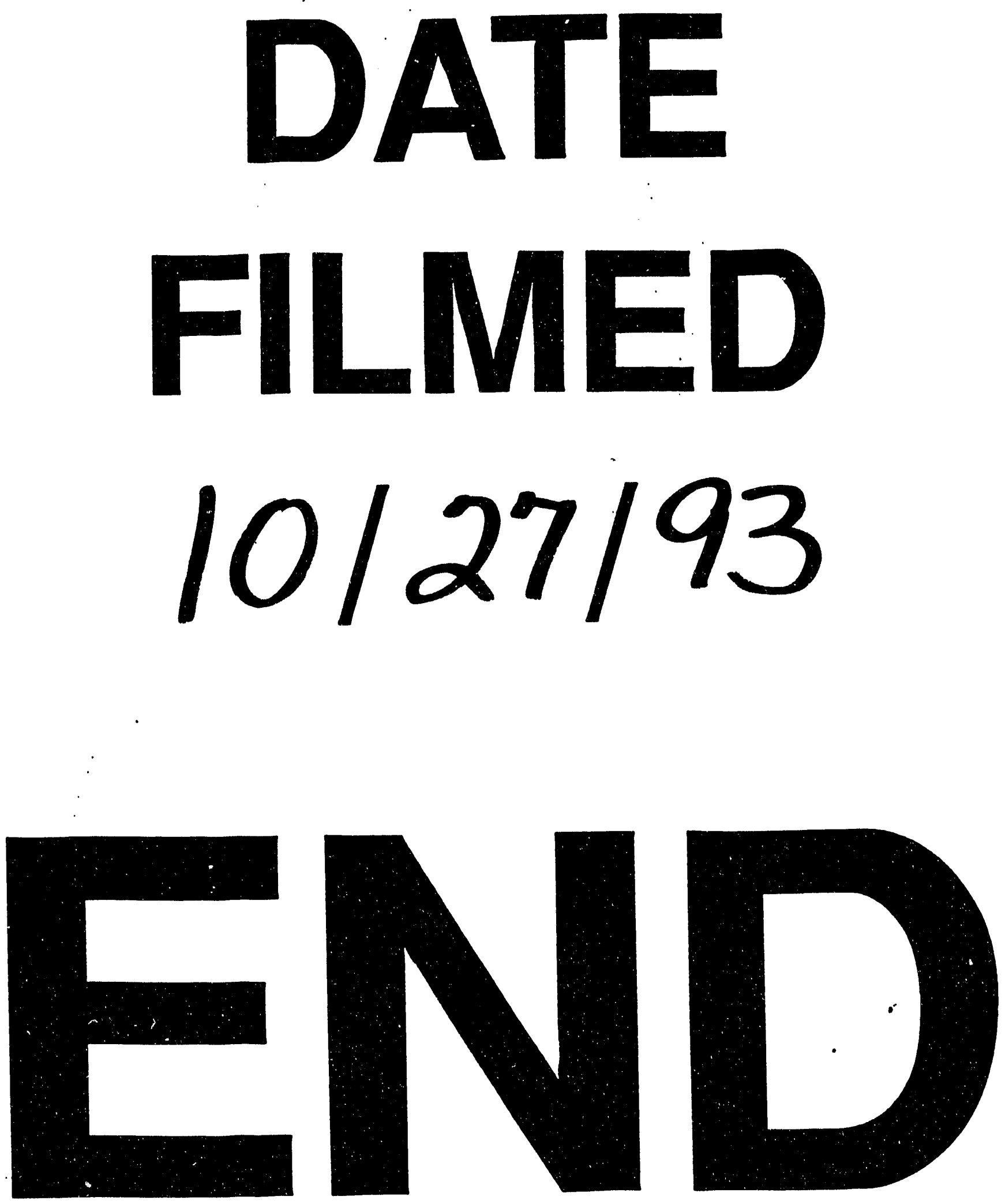
